UNIVERSIDADE DE SÃO PAULO

INSTITUTO DE FÍSICA

FACULDADE DE EDUCAÇÃO

INSTITUTO DE QUÍMICA

INSTITUTO DE BIOCIÊNCIAS

RAFAELA FELIX MUNHOZ DE OLIVEIRA

Uma Licenciatura em Física sob o olhar de seus egressos 
RAFAELA FELIX MUNHOZ DE OLIVEIRA

\title{
Uma Licenciatura em Física sob o olhar de seus egressos
}

\author{
Versão Revisada
}

Dissertação apresentada ao Programa de Pós-Graduação Interunidades em Ensino de Ciências para obtenção do título de Mestre em Ensino de Ciências.

Área de concentração: Ensino de Física

Orientadora: Anne L. Scarinci

São Paulo

2019 


\section{FICHA CATALOGRÁFICA}

\section{FICHA CATALOGRÁFICA}

\section{Preparada pelo Serviço de Biblioteca e Informação}

do Instituto de Física da Universidade de São Paulo

\section{Oliveira, Rafaela Felix Munhoz de}

Uma licenciatura em física sob o olhar de seus egressos. São Paulo, 2019.

Dissertação (Mestrado) - Universidade de São Paulo. Faculdade de Educação, Instituto de Física, Instituto de Química e Instituto de Biociências.

Orientador: Profa. Dra. Anne Louise Scarinci Peres Área de Concentração: Ensino de Física.

Unitermos: 1. Física - Estudo e ensino; 2. Formação inicial de professores; 3. Licenciatura; 4. Ensino de física; 5. Parâmetros positivos da formação. 


\section{AGRADECIMENTOS}

À minha família pelo apoio e suporte durante esses anos de pesquisa, sobretudo à minha mãe, Sandra e ao Vasco.

À minha orientadora, $\operatorname{Prof}^{\mathrm{a}}$ Dr $^{\mathrm{a}}$. Anne por direcionar meu olhar como pesquisadora e por ser uma pessoa que me inspira como professora.

A todas as pessoas que me concederam gentilmente seu tempo e colaboraram com esta pesquisa através seus olhares sobre o curso.

A todos os colegas da Pós-Graduação Interunidades em Ensino de Ciências, especialmente ao Walter.

Também aos professores que tive, principalmente os da Pós-Graduação, por me inspirarem a ser uma professora e pesquisadora melhor.

E à CAPES pelo financiamento desta pesquisa. 
Asas, um outro aparelho preparatório, e que nos permitissem atravessar a imensidão, não nos serviriam de nada, pois, se fôssemos a Marte e a Vênus conservando os mesmos sentidos, eles reverteriam do mesmo aspecto que as coisas da Terra tudo aquilo que pudéssemos ver. A única viagem verdadeira, o único banho de Juvência, seria, não partir em busca de novas paragens, mas ter outros olhos, vero universo com os olhos de outra pessoa, de cem outras, ver os cem universos que cada uma delas vê (...).

Marcel Proust, Em busca do tempo perdido: o caminho de Swann. 


\section{RESUMO}

OLIVEIRA, Rafaela Felix Munhoz. Uma Licenciatura em Física sob o olhar de seus egressos. 2019. 157 f. Dissertação (Mestrado em Ensino de Ciências - Ensino de Física) Instituto de Física, Faculdade de Educação, Instituto de Química, Instituto de Biociências, Universidade de São Paulo, São Paulo, 2019.

A média brasileira de concluintes em cursos de Licenciatura em Física entre os anos 2000 e 2016, segundo o INEP, é de 14 egressos por ano por instituição. Entretanto, para o mesmo período, uma Licenciatura em Física da Universidade de São Paulo apresenta a média de 60 concluintes por ano, um número muito superior à média brasileira. Esse dado é um indicativo de sucesso da instituição de ensino superior e por este motivo, merece ser foco de investigação. A análise documental de seus projetos políticos pedagógicos e propostas curriculares revelou ainda indícios de pioneirismo dessa Licenciatura em relação à formação de professores oferecida. O pioneirismo da Instituição tem como marco o ano de 1993, quando o curso sofreu uma reestruturação curricular que visou, dentre outras coisas, romper com o modelo de formação 3+1 vigente no país e, através disso, estabeleceu uma identidade curricular para a Licenciatura. Essa "nova licenciatura" como foi apelidada, surtiu efeitos positivos, que puderam ser medidos por meio do crescente número de concluintes no curso a partir daquela data. Desde essa reforma, o currículo e o projeto pedagógico passaram por novas adequações, que visaram tornar a graduação oferecida mais consonante com modelos contemporâneos de formação. Diante disso, essa pesquisa propôs levantar alguns elementos com o intuito de compreender como essa Licenciatura em Física vem acontecendo na prática. Foi escolhido o recorte do olhar dos profissionais formados pela instituição. Para isso, foram realizadas entrevistas em formato de relatos de oito egressos do curso, com a finalidade de se verificarem quais suas opiniões, visões e elementos que foram centrais e marcantes - positiva ou negativamente - na formação. Usando a Análise do Conteúdo, foi possível estabelecer os temas mais recorrentes nas entrevistas, que foram agrupados dando origem às dimensões descritivas: O Momento de crise: a escolha pela Licenciatura; Início da atuação como professor de Física em escola; As disciplinas: visões, opiniões e elementos marcantes. Esses dados possibilitaram compor uma descrição de como acontece o processo formativo na visão dos sujeitos entrevistados. A análise dessa descrição nos permitiu constatar alguns pontos sobre essa Licenciatura em Física: as dimensões de análise evidenciaram que a instituição consegue proporcionar parâmetros positivos de formação ao oferecer ao licenciando disciplinas com enfoques em dimensões epistemológicas da Física, disciplinas que proporcionem aos futuros professores conhecimentos que estão contextualizados com o ensino básico, disciplinas que focalizam a dimensão metodológica e disciplinas que valorizem os aspectos práticos da aula. Apesar disso, parece que não ocorre uma apropriação plena das propostas do Projeto Político Pedagógico da Licenciatura em Física pelos docentes; o curso ainda revigora a dicotomização entre a teoria e prática e persistem desafios remanescentes às mudanças curriculares.

Palavras-chave: Formação inicial de professores. Licenciatura. Ensino de Física. Parâmetros positivos de formação. 


\begin{abstract}
OLIVEIRA, R. F. M. A Degree in Physics under the eyes of its graduates. 2019. $157 \mathrm{f}$. Dissertação (Mestrado em Ensino de Ciências - Ensino de Física) - Instituto de Física, Faculdade de Educação, Instituto de Química, Instituto de Biociências, Universidade de São Paulo, São Paulo, 2019.

The national average of graduates in undergraduate courses of Physics Education between 2000 and 2016, according to INEP, is 14 graduates per year per institution. However, for the same period, a Physics Education Degree at the University of São Paulo presents an average of 60 graduates per year, a much higher number than the national average. This data is indicative of the success of the higher education institution and, therefore, deserves to be a research focus. The document analysis of its political-pedagogical projects and curricular proposals also revealed signs of this degree pioneering excellency with respect to physics teacher education. The Institution's pioneering spirit has its starting point on the year of 1993, when the course underwent a curricular restructuring that aimed, among other things, to break with the consecutive $(3+1)$ education model common in the country and, through this, established a curricular identity for the undergraduation. This "new degree" as it was called, had positive effects, which could be measured by the increasing number of graduates. Since this reform, the curriculum and the pedagogical project have undergone new adaptations, all in the direction of making the course more consonant with contemporary models of teacher education. Therefore, this research sought to understand how this Degree in Physics has been happening - and we chose the focus of the professionals egressed from it. For this, semistructured interviews were conducted with eight graduates of the course, in order to verify opinions, visions and elements that were central and remarkable - positively or negatively - in the course. Through Content Analysis Methodology, it was possible to establish the most recurrent themes from the accounts, which were classified giving rise to the descriptive dimensions: Moment of Crisis: the choice for the Degree; Beginning of the performance as teacher of Physics in schools; The disciplines: visions, opinions and important elements. These data allowed us to compose a description of how the education process happens according to the interviewed subjects. Data analysis elicited some points: the analytic dimensions showed that the institution can provide positive training parameters by offering disciplines with epistemological dimensions approaches in Physics, disciplines that provide future teachers with knowledge that is contextualized with the Basic Education, disciplines that focus on the methodological dimension and disciplines that value the practical aspects of the classes. Nevertheless, it seems that the Political Pedagogical Project proposals are not entirely put into practice. The course still invigorates the dichotomization between theory and practice and some remaining challenges of curriculum change persist.
\end{abstract}

Keywords: Teachers Initial Education. Teachers Degree. Physics Teaching. Positive Parameters of Teacher Training. 


\section{LISTA DE QUADROS}

Quadro 1 - Estrutura Curricular da Licenciatura até 1993 ...................................................45

Quadro 2 - Estrutura Curricular da Licenciatura após 1993 - Diurno ................................... 48

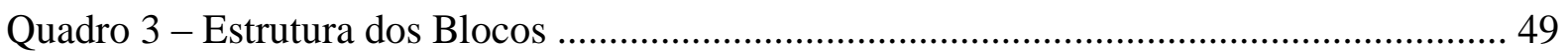

Quadro 4 - Estrutura Curricular da Licenciatura a partir de 2006 - Diurno........................... 56

Quadro 5 - Estrutura Curricular da Licenciatura após 2015 - Diurno.................................... 59

Quadro 6 - Disciplinas com horas de Práticas como Componente Curricular...........................61

Quadro 7 - Disciplinas que têm horas de estágio................................................................. 62

Quadro 8 - Fases do desenvolvimento da pesquisa qualitativa segundo Bardin (2007) e Franco

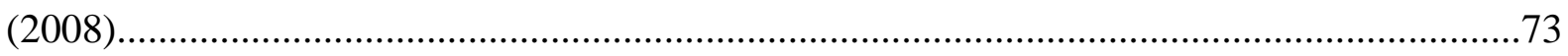

Quadro 9 - Dimensões de análise que se desprenderam das entrevistas ............................... 76

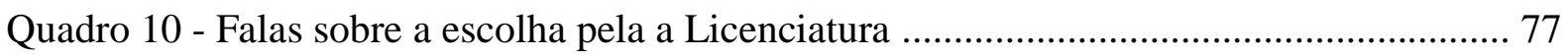

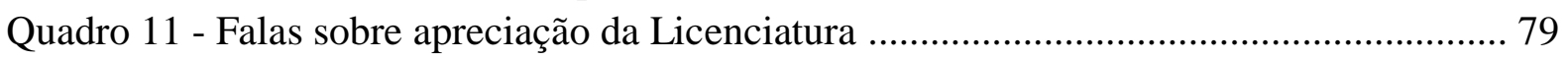

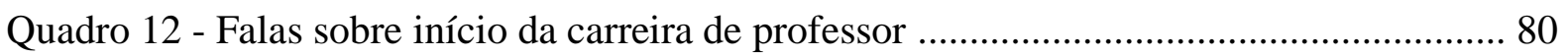

Quadro 13 - Falas sobre disciplinas da Física...................................................................... 84

Quadro 14 - Falas sobre disciplinas da Didática da Física..................................................... 89

Quadro 15 - Falas sobre disciplinas da Formação Pedagógica Geral .................................... 94

Quadro 16 - Dimensões descritivas que se desprenderam das dimensões de análise.............. 97 


\section{LISTA DE TABELA}

Tabela 1 - Codinome dos sujeitos entrevistados e o ano de conclusão da graduação

\section{LISTA DE GRÁFICO}

Gráfico 1 - Evolução do número de concluintes da Licenciatura em Física por ano entre os anos de 1997 a 2016 


\section{LISTA DE ABREVIATURAS E SIGLAS}

BID

CAPES

CIL

$\mathrm{CNE}$

$\mathrm{CNPq}$

Coc-Licenciatura

FAI -

FAPESP -

FE -

FFLCH -

GREF -

IF -

IFUSP -

INEP -

IME -

IP -

IQ -

LDB -

PBEF -

PCC -

PCN -

$\mathrm{PEF}$ -

PIBID -

PIEC -

POEB -

PPP -

PSSC -

USP -
Banco Interamericano de Desenvolvimento

Coordenação de Aperfeiçoamento de Pessoal de Nível Superior

Comissão Interunidades das Licenciaturas

Conselho Nacional de Educação

Conselho Nacional de Desenvolvimento Científico e Tecnológico

Comissão de Coordenação da Licenciatura

Física Auto Instrutiva

Fundação de Amparo à Pesquisa do Estado de São Paulo

Faculdade de Educação

Faculdade de Filosofia, Letras e Ciências Humanas

Grupo de Reelaboração do Ensino de Física

Instituto de Física

Instituto de Física da USP

Instituto Nacional de Estudos e Pesquisas Educacionais Anísio Teixeira

Instituto de Matemática e Estatística

Instituto de Psicologia

Instituto de Química

Leis de Diretrizes e Base

Projeto Brasileiro de Ensino de Física

Prática como Componente Curricular

Parâmetros Curriculares Nacionais

Projeto de Ensino de Física

Programa Institucional de Bolsas de Iniciação à Docência

Pós-Graduação Interunidades em Ensino de Ciências

Política e Organização da Educação Básica no Brasil

Projeto Político Pedagógico

Physical Science Study Committee

Universidade de São Paulo 


\section{SUMÁRIO}

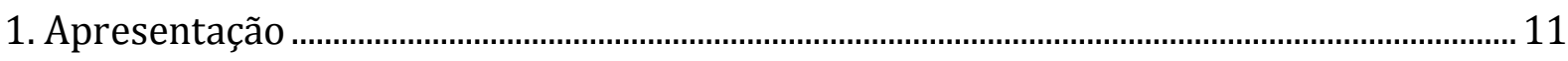

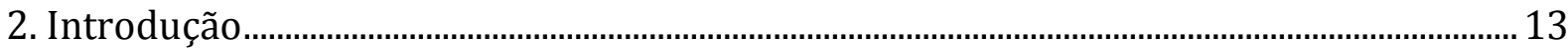

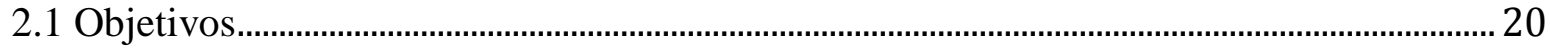

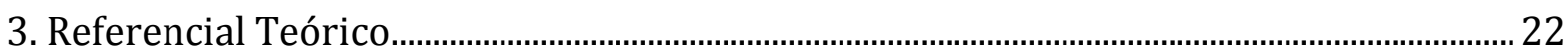

3.1 O Paradigma da racionalidade técnica no ensino e na formação ............................................ 22

3.1.1 Positivismo, comportamentalismo e a Racionalidade Técnica ....................................... 22

3.1.2 Consequência da Racionalidade Técnica na Formação de Professores ........................ 26

3.2 Em defesa de uma nova orientação epistemológica de ensino e de formação.................... 28

3.3 Um modelo de formação profissional na esteira de epistemologias modernas ................. 33

4. A natureza da pesquisa ............................................................................................................

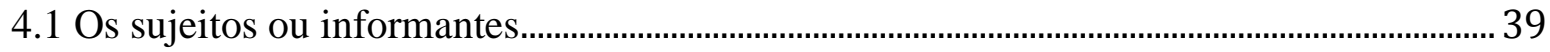

4.2 As entrevistas ............................................................................................................................. 41

5. Análise documental: o caso USP ...................................................................................................... 42

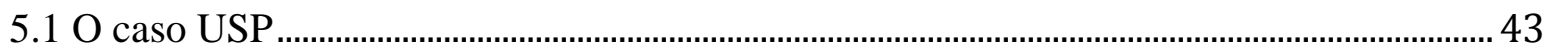

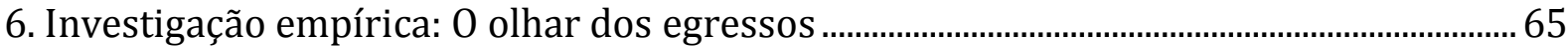

6.1 A produção dos dados - uma busca por dimensões de análise................................................. 71

6.1.1 A Metodologia de Análise do Conteúdo............................................................................ 72

6.1.2 Organização dos dados para análise: criação das dimensões........................................... 75

6.1.3 As dimensões descritivas ........................................................................................................ 96

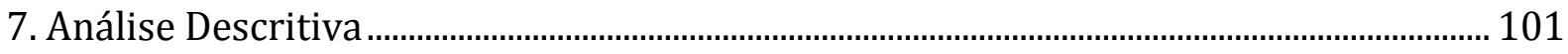

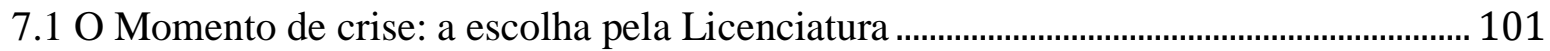

7.2 Início da atuação como professor de Física em escola ......................................................... 106

7.3 As disciplinas: visões, opiniões e elementos marcantes. ...................................................... 112

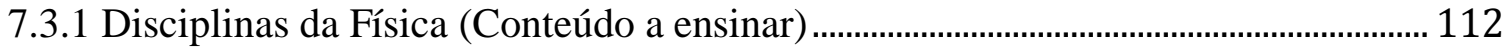

7.3.2 Didática da Física: o "brilho nos olhos"........................................................................ 128

7.3.3 Disciplinas da Formação Pedagógica Geral ..................................................................... 135

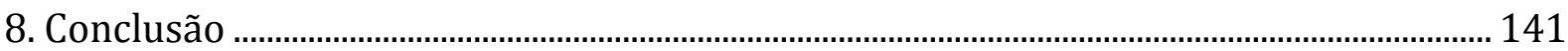

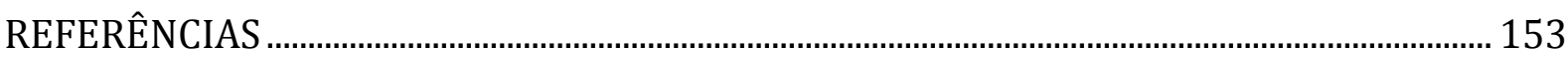




\section{Apresentação}

Durante minha graduação na Licenciatura em Física, em uma instituição do interior de São Paulo, antes do início da carreira como professora, era bastante frequente ouvir dos colegas que estavam no início da profissão (de diversas áreas) muitas queixas sobre a escola, o ensino e os alunos. Eu, naquele momento do processo formativo, não conseguia compreender os motivos das queixas. Compreendia que a escola, pelo menos a pública, estava [e ainda está] em um estado crítico. Mas, não compreendia como aqueles professores, depois da formação inicial em instituições públicas de ensino superior, eram capazes de afirmar que "só conseguiam ensinar e manter os alunos quietos na sala de aula quando copiavam a matéria do livro na lousa e o aluno, da lousa para o caderno". Eu acreditava que a nossa formação era capaz de fornecer ferramentas para lidar com os problemas do ensino. Entretanto, percebia que aqueles professores recém-ingressados na carreira acabavam se submetendo aos mesmos métodos que antes criticavam. A maioria desses professores, senão todos pensavam em desistir. Largar o ensino. Fazer qualquer outra coisa. Achava estranho, pois nós, enquanto alunos da graduação discutíamos Paulo Freire, Momentos Geradores, Concepções Alternativas, o papel da experimentação na sala de aula, uso da tecnologia no ensino, Aprendizagem Baseada em Problemas. Como eles não conseguiam "aplicar" alguma dessas propostas em suas aulas e ajudar os alunos a compreenderem os conteúdos? Como eles, depois das discussões nas aulas sobre pesquisas e artigos que focalizam processos de ensino e de aprendizagem, não conseguiam "aplicar" nenhuma dessas teorias? Por qual motivo eles não conseguiam fazer diferente?

Saí da graduação e fui para a sala de aula com esse problema na cabeça. Descobri uma resposta: nós não fazemos diferente porque nós, recém formados, não sabemos fazer diferente e "na prática, a teoria era outra". Descobri naquele momento que mesmo depois dos anos na Licenciatura em Física, eu não sabia nada sobre a sala de aula. Percebi que, provavelmente, meus colegas também não sabiam.

Ingressei na Pós-Graduação sob esse pano de fundo e algumas questões em mente que almejava compreender: como surgiam as imagens negativas sobre ensino nos professores que acabaram de concluir a graduação em licenciatura? Por qual motivo, em tão pouco tempo, os recém-formados recaíam em práticas transmissivas e modelos tradicionais de ensino? Qual o motivo dos professores enfrentarem os problemas e situações de sala de aula com ações 
baseadas no senso comum? Será que deixamos de aprender algo na nossa formação inicial? Os problemas são dos próprios professores ou seriam consequências do currículo da graduação?

Esse foi o contexto e a motivação da minha pesquisa. Certamente, a jornada que a PósGraduação proporcionou pôde me ajudar, ao mesmo tempo, a encontrar algumas respostas sobre aqueles problemas e formular novas questões.

O tema e o referencial teórico adotados no contexto da pesquisa do Mestrado colaboraram na mudança de direcionamento do meu olhar como Pesquisadora, como Professora e até como Física e a reflexão sobre as questões da Pesquisa entrelaçaram-se com a reflexão sobre meu próprio processo formativo (e de meus colegas). Assim, passei a "ver com outros olhos" as queixas dos professores. 


\section{Introdução}

As queixas que eu ouvia frequentemente dos professores aos alunos e à escola parecem não ser exclusivas deste grupo de professores e das relações entre esses atores. De acordo com Tardif (2002), nos últimos anos, a sociedade também vem criticando o papel do professor e a função social da escola. No atual contexto político do Brasil (2018 - 2019), por exemplo, percebemos uma onda que parece pôr em xeque a função social dessa classe de profissionais e das instituições de ensino. Percebe-se o olhar desconfiado da sociedade em relação aos valores e a ética de professores em todos os níveis ${ }^{1}$.

Além disso, outras profissões também vêm sendo criticadas e experimentando nos últimos 20 anos uma perda de confiança da sociedade, do seu êxito e do seu poder (TARDIF, 2002). Inclusive profissões com alto grau de prestígio social como a medicina, o direito e a engenharia, que são historicamente mais bem assentadas do que a de professor (TARDIF, 2002). Mas, essa crise das profissões, dos conhecimentos e das estratégias profissionais parece circunscrever certo grupo de profissionais. Tardif (2002) propõe que são principalmente aqueles profissionais que no seu fazer prático demandam processos reflexivos, improvisação, agir na indeterminação e criatividade. No geral, são grupos de profissões ligadas diretamente ao ser humano: como professores, médicos e advogados, por exemplo (TARDIF, 2002).

Na tentativa de propor uma compreensão da origem da crise profissional, a formação começa a ser foco de investigações. Disso, suscitam os debates nas esferas acadêmicas sobre os fundamentos epistemológicos da prática e da formação (CONTRERAS, 2002; PERRENOUD, 2002; SCHÖN, 2000; TARDIF, 2002; ZEICHNER, 1993) e sobre como esses fundamentos influenciam a atuação profissional.

Alguns resultados das pesquisas que focalizam a formação superior sugerem que a origem da crise profissional esteja no paradigma da racionalidade instrumental e técnica ancorada no modelo de ciência aplicada sob o qual os profissionais são formados. Esse paradigma de formação teria reflexo no fazer diário dos profissionais cuja atividade é pautada na solução de problemas. Para resolvê-los a partir da lógica instrumental, o profissional aplica rigorosamente teorias e técnicas científicas (CACHAPUZ et al, 2005).

\footnotetext{
${ }^{1}$ O movimento Escola Sem Partido parece ser, no sentido do texto, um porta voz atual dessa desconfiança com a ética e os valores dos professores. A máxima desse movimento é a ideia de que no interior das escolas e universidades os professores utilizam a instrumentalização do ensino para fins políticos, ideológicos e partidários, fazendo do aluno, uma vítima. (Disponível em: https://www.programaescolasempartido.org/)
} 
Por sua vez, a profissão de professor tem como implicações do modelo de formação fundamentado no paradigma da racionalidade instrumental e técnica, a revitalização de percursos de ensino predominantemente transmissivos e instrucionais. O ensino regido por essa lógica radica pressupostos epistemológicos de que os conhecimentos existem fora de nós e podem ser passados (transmitidos diretamente) do professor para o aluno (SANTOS, 2005). De acordo com Santos (2005) os percursos do tipo transmissivo dão grande peso à:

[...] compartimentação disciplinar, à planificação minuciosa das lições, à organização do conhecimento (matéria a ensinar) pelo educador, aos produtos da aprendizagem, à repetição para exercitação da memória e a uma avaliação somativa de tipo normativo, em que se procura que os produtos da aprendizagem ('outputs') se situem tão próximo quanto possível da informação recebida ('inputs'). (SANTOS, 2005, p. 26)

Acontece que o ensino predominantemente do tipo transmissivo acaba asfixiando o caráter investigativo da educação, pois cultiva a ideia de que o aluno é um espectador. $\mathrm{O}$ professor, nesse tipo de ensino, estabelece na sala de aula uma comunicação unilateral e vertical de retóricas e de conclusões. Santos (2005) conclui que esse ensino acaba por abafar os novos modos do aluno se relacionar com o conhecimento.

Embora a presença de modelos regidos pela lógica instrumental e técnica no ensino tenham implicações negativas na aprendizagem de Ciências, as Instituições que formam os professores ainda estão alicerçadas, na maior parte, em bases pedagógicas conservadoras e tradicionais idealizadas segundo a lógica aplicacionista (TARDIF, 2002, p. 270). Um exemplo disso é o modelo institucionalizado de Pesquisa, Formação e Prática nas universidades, concebidos como três polos separados na formação profissional. Nessa concepção, os pesquisadores são os produtores do conhecimento, que é em seguida transmitido na formação e, ao final do processo de formação, os conhecimentos serão aplicados na prática. Convém ainda destacar outros problemas que os moldes aplicacionistas na formação implicam (TARDIF, 2002):

a) Por ser idealizado segundo a lógica disciplinar, o modelo aplicacionista não permite relação entre as disciplinas. Portanto, elas são altamente fragmentadas e especializadas, como unidades autônomas, fechadas em si e de curta duração. Por esse motivo, as disciplinas causam pouco impacto nos alunos, pois parte-se do pressuposto de que aprender é conhecer;

b) Como consequência da lógica de que "aprender é conhecer", estabelece-se a dicotomia em relação à prática (em que aprender é fazer), que não é vista como um conhecimento. Tal dicotomia provém do tratamento aplicacionista que dissocia o 
conhecer e o fazer como duas unidades distintas na formação, subordinando temporalmente e logicamente o fazer ao conhecer;

c) Outro problema é que o modelo aplicacionista não leva em consideração as crenças e representações anteriores dos graduandos a respeito do ensino. Sem executar um trabalho profundo nos "filtros cognitivos", a formação acaba tendo um impacto pequeno no que os alunos pensam,creem e sentem. Assim, os licenciandos terminam a formação sem terem tido suas crenças "abaladas" (TARDIF, 2002, p. 273) e sem a oportunidade de construírem novas crenças mais coerentes com a teoria que aprenderam.

Pelas razões acima elencadas é que talvez os professores em início de carreira acabem reproduzindo as mesmas metodologias que vivenciaram no seu processo de formação, reforçando práticas pedagógicas que têm referências em paradigmas conservadores e epistemologicamente obsoletos. Além disso, pode ser esse o motivo pelo qual os professores iniciantes acabam concebendo a educação, o ensino, a aprendizagem, a escola e o ser professor, ancorados em crenças educacionais que surgiram quando estavam ainda na situação de alunos do ensino básico. São essas as situações em que se encontram os iniciantes na carreira de professor. De acordo com Alarcão (2003) tal quadro decorre da inabilidade das instituições de ensino superior em preparar os futuros profissionais para lidarem com situações novas, ambíguas, confusas, para as quais nem as teorias aplicadas e nem as técnicas de decisão e os raciocínios aprendidos são capazes de fornecer soluções lineares (ALARCÃO, 2003).

Além de toda a problemática que envolve as profissões que trabalham muito próximas ao ser humano - a de professores, especificamente - e os modelos de formação, a formação de professores de Física e o Ensino de Física parecem demonstrar uma conjuntura ainda mais complexa. Na década de 1960, o ensino dessa ciência tomou impulso motivado pelo desenvolvimento científico e tecnológico ocasionado pela "corrida espacial" e pela industrialização (GASPAR, 1995; MOREIRA, 2000). Como estavam surgindo novas carreiras técnicas, principalmente na área industrial, isso produziu a sensação da necessidade de se ensinar física para uma melhor inserção de profissionais mais capacitados no mercado de trabalho. Entretanto, até 1950 o paradigma brasileiro de ensino era pautado em livrostexto, mas com a influência norte americana na educação, começaram a ocorrer no país tentativas de superação desse modelo de ensino. Nesse período, o Brasil recebeu assistência técnica e cooperação financeira para implantação de projetos como o Physical Science Study Committee - PSSC. Isso resultou em intensa atividade de tradução e treinamento de 
professores, que tinham como objetivo modificar substancialmente o ensino de Física da época no Brasil (PENA, 2012). O PSSC tinha uma proposta metodológica revolucionária para a época, com texto diferenciado, linguagem moderna, sequencial de conteúdos novos e incorporação de tópicos pouco explorados no corpo dos textos tradicionais, além de prática experimental arrojada, filmes produzidos especialmente para o projeto, conteúdo alinhado à dinâmica metodológica, guias de laboratório, entre outros (ALVES FILHO, 2000); foi o projeto de Física mais disseminado mundialmente. No Brasil, deu bases à formação de toda uma geração de professores; segundo Alves Filho (2000), revolucionou o pensar acadêmico sobre ensino de Física e foi a semente que motivou projetos como o Projeto de Ensino de Física - PEF, a Física Auto Instrutiva - FAI e o Projeto Brasileiro de Ensino de Física - PBEF. Porém, os materiais utilizados foram insatisfatórios para as necessidades e possibilidades das escolas brasileiras. As críticas eram alicerçadas na ideia de que aqueles projetos "importados" não visavam atingir a grande massa da população. Além disso, as escolas sofriam de carência de infraestrutura, os professores não receberam suporte, a remuneração dos docentes era baixa, não houve incentivos ao aperfeiçoamento docente e principalmente, às necessidades do professor não foram levadas em consideração. Para Moreira (2000) também faltou uma concepção de aprendizagem que ancorasse a proposta, ou seja, os projetos foram muito claros em dizer como se deveria ensinar a Física, mas pouco ou nada disseram sobre como se aprenderia essa mesma Física. Então, a contribuição desse projeto para o ensino de ciências no Brasil acabou ficando confinado a universidades.

Como decorrência da industrialização no Brasil, nesse período ocorre o aumento da população, o aumento das indústrias, a redefinição do papel da mulher como trabalhadora e a elevação dos requisitos educacionais para o preenchimento dos cargos públicos e privados (ARAUJO; MIRANDA, 2010). Todos esses fatores intensificaram o número de matrículas no ensino primário e secundário. Com isso, a demanda por professores tornou-se maior, o que forçou as universidades aumentarem o número de vagas no ensino superior. Culmina disso o aumento induzido de vagas nas universidades federais, principalmente em cursos de maior demanda social (ARAUJO; MIRANDA, 2010), que englobam as Licenciaturas. Todos esses fatores podem ter contribuído direta ou indiretamente para deteriorar a qualidade do ensino superior (e dos demais níveis) no país e, além disso, geraram um excedente de gastos para o governo. Assim, em 1968, o governo federal implementou a Reforma Universitária. De acordo com Araújo e Miranda (2010), essa reforma visava basicamente transformar a universidade em uma empresa cuja finalidade era produzir Ciência, Técnica e Cultura, sendo a eficiência obtida com o aumento da produtividade e a redução dos custos. Como 
consequência da reforma para reduzir os excedentes de gastos, ocorre a unificação dos vestibulares, a fragmentação das graduações em dois ciclos (básico e profissional), a oferta de cursos de graduação de duração reduzida e a mudança do regime seriado para o de créditos. Concomitante a esse processo, em 1971, a Lei de Diretrizes e Bases fixou a formação mínima para o exercício do magistério e introduziu no cenário educacional brasileiro as Licenciaturas de curta duração, o que acarretou na redução do nível de qualidade da formação de professores. Como era exigido apenas um currículo mínimo no curso de Licenciatura em Ciências para o ensino de $1^{\circ}$ e $2^{o}$ graus - como era chamado o Ensino Fundamental e Ensino médio na época - esse currículo, imposto como modelo único e obrigatório, substitui a formação em graduação plena pela figura do professor polivalente (GATTI, 2010).

Os efeitos provocados pela adoção dos procedimentos de Reforma Universitária, da fixação da formação mínima pela LDB e da tentativa de adoção de projetos como o PSSC no ensino de Física mantêm-se objetos de estudo no campo da pesquisa educacional, de um modo geral, e da pesquisa em Ensino de Ciências, em específico, até hoje. Porém, os dados já trazidos por essas pesquisas são desanimadores. Eles evidenciam que as tentativas de mudanças de perspectiva de ensino e de formação tornaram-se inócuas. A respeito da evolução das condições de ensino e da prática do Ensino de Física destacamos os seguintes problemas que persistem:

a) As falhas conceituais, a carência de conhecimentos específicos da profissão e a falta de habilitação para o ensino de Física em professores que lecionam essa disciplina (CARVALHO; GIL-PÉREZ; 2000);

b) A reduzida taxa de concluintes nos bacharelados e nas licenciaturas em física devido ao não preenchimento de vagas e à evasão, apesar da demanda por professores de física ter aumentado de ano para ano (LIMA JÚNIOR, 2013);

c) Muitos dos livros de ciências e kits experimentais inicialmente empregados no país durante quase 30 anos para a educação científica que foram importados, traduzidos ou adaptados (PSSC e o Projeto Harvard) se mostraram impraticáveis com professores brasileiros (GASPAR, 1995; MOREIRA, 2000). Vale ressaltar que diante disso, surgiram alguns projetos que estimularam a produção nacional de "tecnologia do ensino de física", entretanto:

Projetos como: Física PSSC, PEF, PBEF, FAI, IPS (Introductory Physical Science), que pretenderam sanar as deficiências do ensino de Física, mostraram-se inviáveis à realidade educacional (inadequação ao sistema educacional brasileiro) àquela época inclusive os nacionais praticamente desapareceram de circulação e uso[...] que, após alguns anos de utilização, pouca ou nenhuma difusão foi constatada na rede escolar, 
a não ser na rede escolar paulista, onde tiveram maior repercussão e difusão. (PENA, 2012, p.2)

d) A troca de experiências didáticas bem-sucedidas (boas práticas) é fraca por conta da pouca interação entre os professores de física. Tradicionalmente, essa interação acontece em congressos, simpósios, encontros de professores, e outros (CARVALHO; GIL-PÉREZ, 2000);

e) Parece faltar clareza ao professor sobre quais os fundamentos para a escolha da metodologia de ensino, dos recursos didáticos, do método de verificação de aprendizagem, etc. (CARVALHO; GIL-PÉREZ, 2000);

f) Apesar do treinamento direcionado ao vestibular, na educação superior, os ingressantes apresentam uma formação científica extremamente deficiente (ADMIRAL, 2016);

g) Condições de trabalho do professor pouco estimulantes: baixo nível da remuneração que desestimula os jovens em optarem pela profissão, excesso de trabalho e de atribuições, insuficiência de instalações adequadas, e desprestígio políticoinstitucional (PUGLIESE, 2017; NÓVOA, 2001).

Todos esses fatores corroboram com uma Física ensinada distanciada e distorcida do seu real propósito pois, os saberes pedagógicos, ao longo de muitos processos formativos, foram sendo cristalizados como receitas de dar aulas. Dessa maneira, os professores acabam reiterando visões distorcidas ou empobrecidas da Ciência, reduzindo a aula basicamente à apresentação de conhecimentos já elaborados, sem oportunizar aos estudantes alguma aproximação das atividades características do trabalho científico (CACHAPUZ et al, 2005). Isso pode ser consequência também da presença do paradigma da racionalidade técnica como modelo de formação.

Todos estes fatores nos levam a crer que a formação de professores de Física (e de Ciências) carece de uma drástica reestruturação didática que oportunize ao futuro professor, além do profundo conhecimento da matéria a ensinar (distanciada de modelos reducionistas), a apropriação de uma concepção de ensino e de aprendizagem como construção de conhecimentos (CARVALHO; GIL-PÉREZ, 2000). Isso nos leva a pensar sobre quais seriam as necessidades formativas dos professores nesse contexto. Nesse sentido, Carvalho e GilPérez (2000) propõem um conjunto de "conhecimentos e destrezas" (CARVALHO; GILPÉREZ, 2000, p. 18) que se configuram como as necessidades formativas [básicas] do professor de Ciência (e Física) que a formação inicial deveria prover:

1. Conhecer a matéria a ser ensinada; 
2. Saber questionar as ideias docentes de senso comum sobre o ensino e a aprendizagem de ciências;

3. Ter conhecimentos teóricos sobre a aprendizagem das ciências;

4. Saber analisar criticamente o ensino tradicional;

5. Saber preparar atividades capazes de gerar uma aprendizagem efetiva;

6. Saber dirigir o trabalho dos alunos;

7. Saber avaliar;

8. Adquirir a formação necessária para saber associar o ensino à pesquisa didática.

Às constatações feitas sobre os problemas que atingem cursos de formação de professores são acrescidos alguns outros problemas que as Licenciaturas em Física especificamente enfrentam e que carecem de soluções. Destacamos:

- A urgente necessidade de uma mudança na concepção curricular dos cursos destas licenciaturas [e de outras graduações] (GUIMARÃES, 2014);

- O insucesso em relação ao desempenho acadêmico dos seus licenciandos (ALVES, 2010);

- Os baixos índices de satisfação em relação à própria formação (GUIMARÃES, 2014).

Toda essa problemática que se assenta na formação de professores de Física demonstra a relevância do tema. Além disso, a enorme quantidade de pesquisas feitas e que ainda estão surgindo sobre o tema, sinalizam que muitos problemas em relação à formação de professores de Física ainda estão em aberto. Destas circunstâncias, decorre a nossa motivação para estudar a formação de professores de física no âmbito de um dos principais centros de formação inicial de professores de São Paulo. A importância que conferimos a esse objeto de estudo se dá principalmente por comparação a outros centros do país. O nosso lócus de pesquisa é um dos centros de formação mais antigo do Estado de São Paulo e oferece curso de Licenciatura desde 1930, além disso possui alguns indícios de sucesso em termos de formação se comparado com outros centros de formação de professores de Física do país que merecem ser analisados e colocados em evidência. 


\subsection{Objetivos}

Diante da problemática que envolve a formação de professores de Física e o ensino dessa ciência, principalmente em relação às altas taxas de evasão dos cursos de Licenciatura em Física, o baixo número de concluintes nesses cursos, o insucesso em relação ao desempenho acadêmico e o baixo índice de satisfação em relação à própria formação, o objetivo geral desta pesquisa é compreender como é o processo formativo proporcionado por uma instituição de ensino que oferece uma graduação em Licenciatura em Física, sob o ponto $\underline{\text { de vista de alguns de seus egressos. Buscaremos comparar as percepções dos profissionais }}$ formados entrevistados sobre a Licenciatura em questão, com as ambições constantes nos documentos oficiais que norteiam o programa de formação.

O interesse em investigar essa Licenciatura em Física decorre de alguns indícios de pioneirismo dessa instituição em termos de currículo e das propostas preconizadas no Projeto Político Pedagógico. Esse curso passou, ao longo de 30 anos, por algumas readequações e reestruturações curriculares, sendo a primeira mudança ocorrida em 1993 que buscou separar o curso de Licenciatura em Física do currículo do curso de Bacharelado em Física. Estas readequações visaram promover uma formação de professores mais consonantes às demandas atuais de ensino e de formação através de propostas de formação contemporâneas e, além disso, promover o aumento do número de concluintes do curso.

A grande reestruturação curricular pela qual a Licenciatura em Física em questão passou, de fato, surtiu efeitos no número de formados por ano. Entre os anos 2000 a 2016 a Instituição formou uma média de 60 alunos por ano $^{2}$, cerca de 30 alunos formados no curso noturno e no diurno. Esse quadro destoa dos dados sobre evasão e baixo número de formados dos cursos de Licenciatura em Física do Brasil, que apresentou uma média de 6 concluintes por curso por ano ${ }^{3}$, entre os anos 2013 a 2016. Esses dados são indicativos de que no lócus desta pesquisa possam ocorrer parâmetros positivos de formação. Esses parâmetros parecem ficar mais evidentes à luz da análise documental dos projetos pedagógicos da Licenciatura em questão. Através dessa análise, é possível constatar algumas mudanças que o currículo dessa Licenciatura em Física sofreu e vem sofrendo desde 1993. Todas essas mudanças propunham

\footnotetext{
${ }^{2}$ Fonte: Seção de alunos da Licenciatura em Física do IFUSP.

${ }^{3}$ Fonte: INSTITUTO NACIONAL DE ESTUDOS E PESQUISAS EDUCACIONAIS ANÍSIO TEIXEIRA. Sinopse Estatística da Educação Superior 2015. Brasília: Inep, 2016. Disponível em:

<http://portal.inep.gov.br/web/guest/sinopses-estatisticas-da-educacao-superior>. Acesso em: 03/10/2018.
} 
adequações curriculares que tentaram, dentre outras coisas, romper com paradigmas de formação ultrapassados.

Devido à abrangência da temática do presente estudo e os vários caminhos e enfoques possíveis que ele possibilita, a proposta desta pesquisa é fazer um recorte do que faz parte de uma investigação maior. Este recorte engloba o estudo documental da Licenciatura em Física da Instituição de Ensino Superior escolhida como lócus visando compreender o percurso dessa Instituição para elaboração e amadurecimento do Projeto Político Pedagógico e do currículo. Por isso, buscaremos comparar os dados da análise documental da Licenciatura em questão com a evolução da Legislação brasileira acerca da formação de professores e da formação de professores de Física e do número de concluintes nestes cursos. Além disso, nesse recorte também buscaremos ouvir de alguns profissionais formados por essa Instituição suas percepções sobre a formação vivenciada.

Com isso, o objetivo mais específico é responder as seguintes questões: o que possibilitou ou influenciou os egressos entrevistados a persistirem e concluírem o curso? De quais conhecimentos os egressos ainda sentem falta em sua atuação profissional? Como avaliam o curso que fizeram em relação às suas necessidades profissionais? Quais parâmetros positivos de formação que essa instituição promove/promoveu de acordo com os entrevistados? 


\section{Referencial Teórico}

Este capítulo visa apresentar qual o teor das discussões teóricas acerca do paradigma vigente de formação. Pretendemos sintetizar as bases teóricas desse paradigma e as consequências que ele acarreta na formação inicial e no ensino. Em seguida, apresentaremos brevemente uma proposta teórica de paradigma emergente proposta por Schön (2000), seu fundamento e as consequências esperadas como modelo de formação. A ideia principal contida nessas discussões é a de crítica ao modelo da racionalidade técnica, modelo esse que parece ensejar na formação de professores algumas consequências que comprovadamente são inadequadas em termos de currículo e de prática e que se têm mostrado desfavoráveis aos processos de ensino e de aprendizagem de ciência e da profissão docente.

\subsection{O Paradigma da racionalidade técnica no ensino e na formação}

\subsubsection{Positivismo, comportamentalismo e a Racionalidade Técnica}

O positivismo foi um movimento de pensamento que dominou parte da cultura europeia (filosofia, artes, literatura) entre, aproximadamente, 1840 até a $1^{\text {a }}$ Guerra Mundial. O termo foi cunhado devido ao período de paz reinante na Europa, que gerou um clima de entusiasmo em torno da ideia de progresso humano e social irrefreável.

Enquanto corrente filosófica, o positivismo situou-se em tradições culturais distintas: na França, inseriu-se no racionalismo de Descartes a Auguste Comte; na Inglaterra, tradição empirista e utilitarista de John Stuart Mill e Herbert Spencer; na Alemanha, pode ser identificada no cientificismo e monismo materialista em Ernst Haeckel e Jacob Moleschott; na Itália, no naturalismo renascentista, de Roberto Ardigò. Influenciou também diferentes produções humanas e demarcou, antes de tudo, o espírito da época. No entanto, apesar das diversificações apresentadas, o positivismo apresenta similitudes que permitem identificá-lo como movimento de pensamento. Tais convergências podem ser enumeradas da seguinte forma (SILVINO, 2007): 
- O positivismo reivindica o primado da ciência: nós conhecemos somente aquilo que as ciências naturais nos dão a conhecer - o único método de conhecimento é o das ciências naturais;

- O método positivista pressupõe que a obtenção de leis causais e domínio sobre os fatos que podem ser utilizado para o estudo da sociedade;

- Afirma a unidade do método científico e o primado desse método como instrumento cognoscitivo;

- Exalta a ciência como o único meio em condições de resolver, ao longo do tempo, todos os problemas humanos e sociais;

- Pronuncia-se pela "divindade" do fato;

- Toma alguns aspectos da tradição iluminista, cuja tendência é considerar os fatos empíricos como a única base do verdadeiro conhecimento, a fé na racionalidade científica como solução dos problemas da humanidade e a confiança acrítica, leviana e superficial na estabilidade e no crescimento sem obstáculos da ciência.

Essa corrente de pensamento influenciou também a Psicologia, que buscava naquele período sua identidade como Ciência (SILVINO, 2007). Nesse contexto, o Behaviorismo se desenvolveu. Essa teoria e método de investigação psicológica enfatiza o comportamento e a sua relação com o meio e, através dela, estabeleceu como unidades básicas para uma análise descritiva do comportamento os conceitos de "estímulo" e "resposta". A partir da definição dessa base conceitual o ser humano passou a ser estudado como produto das associações estabelecidas durante sua vida entre os estímulos do meio e as respostas que são manifestadas pelo comportamento. Apesar de Watson ter sido o grande precursor do Behaviorismo, B. F. Skinner foi um dos psicólogos behavioristas que teve seus estudos amplamente divulgados, inclusive no Brasil, havendo um grau de aplicabilidade muito forte na educação. Diante das teses comportamentalistas propostas por Skinner, a educação passou a ser compreendida como uma ciência aplicada em que eram desconsiderados no processo de aprendizagem os aspectos internos que ocorriam na mente do indivíduo, restringindo a análise ao comportamento observável.

Essa visão de educação como uma ciência aplicada, que perdura até os dias atuais, foi responsável pela difusão do pensamento de que o ensino melhoraria pela aplicação do método científico. Assim, o papel da teoria seria o de iluminar o pensamento dos professores. De acordo com essa visão, a prática educacional é baseada na aplicação do conhecimento científico e, questões educacionais são tratadas como problemas de natureza técnica. A compreensão é a de que os problemas possam ser resolvidos objetivamente por meio de 
procedimentos racionais da ciência - essa é uma concepção aplicacionista. Além disso, “a teoria educacional pode usar leis causais para prever e, portanto, controlar os resultados de diferentes cursos da ação prática" (CARR; KEMMIS, 1986, p. 66).

O pensamento decorrente da visão de educação como ciência aplicada acabava atribuindo aos pesquisadores da educação a mesma função das dos cientistas das ciências naturais. Nesse pensamento, assim como o cientista natural persegue o conhecimento objetivo por meio da investigação científica, os pesquisadores da educação seriam capazes de fornecerem "respostas para questões científicas que foram levantadas dentro de um quadro de fins educacionais" (CARR; KEMMIS, 1986, p. 70). Assim, ambas permaneceriam como atividades neutras e livres valores.

Nas instituições de ensino superior, essa visão cientificista radica ainda um modelo hierárquico de conhecimento. Esse modelo institucionaliza que a pesquisa fornece a ciência básica e aplicada, das quais derivam as técnicas para o diagnóstico e solução dos problemas da prática. Dessa forma, os profissionais da 'prática' supostamente suprem os pesquisadores com problemas para estudo e testes a respeito da utilidade dos resultados de pesquisa. Nessa concepção, portanto, o papel do pesquisador é distinto do papel do aplicador (professor) e é, normalmente, considerado superior (SCHÖN, 2000). E, essa divisão hierárquica [e dicotômica] entre pesquisa e prática se reflete no currículo normativo das universidades, cuja regra é a de que as disciplinas da ciência básica e aplicada devem vir primeiro no processo formativo. As habilidades para solução dos problemas advindos do mundo real utilizando-se as teorias e as técnicas devem vir depois, quando os estudantes já tiverem aprendido a ciência relevante. Isso porque se supõe que os estudantes não podem aprender habilidades de aplicação sem antes terem aprendido o conhecimento aplicável e também porque essas habilidades são tidas como um tipo ambíguo e secundário de conhecimento (SCHÖN, 2000)

Essas são as bases do modelo da racionalidade técnica (SCHÖN, 2000), racionalidade instrumental (HORKHEIMER, 2002) ou científica (KUHN, 2017)na formação. Esse modelo epistemológico da prática fundamentado no paradigma científico positivista consolidou a estrutura da formação e da prática profissional que dela deriva. A racionalidade técnica defende a ideia de que os profissionais solucionem os problemas instrumentais mediante a seleção dos meios técnicos que derivam do conhecimento sistemático obtidos na universidade (SCHÖN, 2000). No caso da profissão de professor alicerçada na racionalidade técnica, esse profissional é visto como um técnico ou um especialista que rigorosamente põe em prática as regras científicas e/ou pedagógicas. E a prática é a de um organizador dos processos de ensino, dos objetivos, da seleção dos conteúdos, das estratégias de ensino, da avaliação, etc., 
que são planejados de modo a garantir os melhores resultados instrucionais. O desempenho dos alunos é tratado, dessa forma, como problema técnico, resolvido por meio dos procedimentos racionais da ciência.

O questionamento a este tipo de profissionalização é o de que quando se esgota o repertório teórico e os instrumentos construídos como referenciais, como o profissional saberia lidar com a nova situação? Na vida prática o profissional geralmente encontra-se em situações que são novidade, ambíguas, confusas, para as quais as teorias aplicadas e as técnicas de decisão a raciocínio podem não ser capazes de fornecer soluções lineares. A maioria das situações não apresenta uma estrutura clara e bem definida, cada uma parece ser um caso único.

Como consequência do predomínio da racionalidade técnica nas pedagogias por sua vez, acabam sendo revitalizados percursos de ensino predominantemente transmissivos e instrucionais (SANTOS, 2005). Nesse tipo de percurso o professor tem sua prática centrada em uma aula em que ocorre frequentemente a exposição de retóricas, instruções e de suas próprias ideias. A meta do aluno é de receber a informação, submetendo-se à estrutura cognitiva do que deve ser aprendido e à autoridade do professor. $\mathrm{O}$ professor tem a figura de detentor do saber, cuja meta é transmitir ideias pensadas por si ou por outros, conceitualizadas e depois injetadas no aluno. Estes percursos têm acentuado pendor livresco, verbalista, impositivo, com grande peso à compartimentação disciplinar, planificação minuciosa das lições e organização do conhecimento, com repetição dos exercícios e memorização e avaliação somativa do tipo normativo. Destacam-se as atividades sensoriais como ouvir, ver manipular e mecânicas, de imprimir e armazenar informações dos conhecimentos que existem fora de nós. Essas são as bases de pedagogias conservadoras e tradicionais, idealizados segundo a lógica aplicacionista (SANTOS, 2005) no paradigma da racionalidade técnica e instrumental.

No ensino de Ciências, as consequências das pedagogias do tipo predominantemente transmissivas têm fracassado em relação à aprendizagem. As expectativas postas nas contribuições da aprendizagem das ciências nas escolas não têm se cumprido e há uma crescente recusa e interesse dos estudantes nos estudos da ciência (CACHAPUZ et al, 2005). Ao contrário das expectativas postas na Educação Científica, o tipo de ensino predominantemente transmissivo acabou disseminando imagens distorcidas da ciência. Tais imagens iteram ideias empobrecidas e distorcidas do fazer científico e criam desinteresse e obstáculos para a aprendizagem. Isso está relacionado com o fato de que o ensino básico e o universitário, ancorados em modelos transmissivos, reduziu-se basicamente à apresentação de 
conhecimentos já elaborados como dogmas em que a ênfase recai na capacidade do aluno armazenar e acumular informações, memorizando leis, enunciados e teorias como expressão da verdade. Dessa maneira, as concepções sobre ciência e o fazer científico dos estudantes [e futuros docentes] não se afastam de imagens populares ou de senso comum (FERNANDEZ et al, 2002) e o dogmatismo do ensino é questionado pelos alunos frente a outros dogmas concorrentes.

\subsubsection{Consequência da Racionalidade Técnica na Formação de Professores}

No final dos anos de 1930, na formação de bacharéis nas poucas universidades então existentes no Brasil, acrescentou-se um ano dirigido à formação de docentes para o ensino secundário, equivalente ao Ensino Médio hoje. Esse tipo de formação, que veio a denominarse popularmente $3+1$, visava incorporar disciplinas da área de educação de maneira compartimentada nesse ano a mais da graduação do bacharelado para permitir a obtenção do diploma da licenciatura (GATTI, 2010). No Brasil, a legislação manteve esse modelo até 2002 para formação inicial, que vigorou oficialmente para a grande maioria dos cursos, quando foram publicadas as novas diretrizes para a formação de professores da Educação Básica (BRASIL, 2002).

O currículo da formação no modelo $3+1$ apresenta algumas características problemáticas. Uma delas está relacionada à subordinação hierárquica da formação pedagógico-didática, frente ao domínio específico dos conteúdos da área de conhecimento correspondente à disciplina que o professor irá lecionar. Como as disciplinas de cunho pedagógico ficavam confinadas ao último ano, muitas vezes elas eram encaradas de maneira marginalizada e secundarizada. A ideia que isso transmite é a de que o conhecimento pedagógico e didático virá inevitavelmente em decorrência do domínio dos conteúdos do conhecimento logicamente organizado. O currículo nos moldes $3+1$ revela ainda, a partir da à subordinação entre as disciplinas do conteúdo a ensinar e as disciplinas de cunho pedagógico geral e o fato do estágio ser realizado no final desse processo, a dicotomização entre o conhecimento e a prática. Essa dicotomização acontece por causa da idealização da formação segundo o modelo aplicacionista do conhecimento: os alunos passam certo número de anos assistindo aulas baseadas em disciplinas, cujos conhecimentos proporcionados são proposicionais. Em seguida vão estagiar, para aplicarem esses conhecimentos (TARDIF, 2002). 
No limite dessa concepção de formação de professores, que acabou por se generalizar, muitas Licenciaturas foram se transformando em cursos inócuos, pois, no confronto com a realidade social e escolar, boa parte dos ex-alunos acabava por apontar que na prática, a teoria é outra. É nesse contexto de fragilidades e dicotomias que historicamente se tornaram secundários os cursos de Licenciatura.

Os modelos aplicacionistas de formação, que se expressam por meio do currículo ancorado no paradigma da racionalidade técnica, comportam outros problemas fundamentais. O primeiro problema, por ser idealizado segundo a lógica disciplinar e não segundo a lógica profissional, centrada no estudo da realidade do professor, as disciplinas da formação não têm relação entre si, sendo altamente fragmentadas, especializadas, como unidades autônomas, fechadas em si mesmas e de curta duração (TARDIF, 2002). De acordo com Tardif (2002) isso acarreta pouco impacto nos alunos, pois, essa lógica disciplinar é regida por questões do conhecimento em que aprender é conhecer. Isso preconiza a dissociação entre o conhecer e o fazer como duas unidades distintas e separadas da formação. O segundo problema é que os modelos aplicacionistas não levam em consideração as crenças dos alunos e suas representações anteriores em relação ao ensino. Isso se limita, na maior parte das vezes, a fornecer aos futuros professores conhecimentos proposicionais de informações. Assim, os filtros cognitivos anteriores à formação, decorrentes da história de vida dos indivíduos e da sua história escolar, permanecem inalterados depois da formação, fortes e estáveis. As crenças dos formados não são abaladas, permanecendo as mesmas de antes do processo formativo e que serão habitualmente reforçadas diante dos processos de socialização do professor e início da carreira.

McDermott (1990) contribui com outros problemas fundamentais que os modelos aplicacionistas, 3+1, comportam em relação à formação de professores de Física (e de qualquer outra matéria). No que se refere aos conteúdos científicos, a universidade oferece um curso padrão sem uma especial preparação para os futuros professores, pois considera-se que isso seja responsabilidade das escolas ou das disciplinas pedagógicas. Portanto, encerra-se nisso a ideia de que a formação científica (do conteúdo a ensinar) não difere entre a do professor, a de um profissional que vai para a indústria ou a de um pesquisador. Do modelo supracitado decorre ainda (MCDERMOTT, 1990, p. 737):

a) $\mathrm{O}$ formato expositivo das aulas estimula uma aprendizagem passiva, assim os professores habituam-se a receber (e proferir) conhecimentos e não a ajudar a gerá-los; 
b) Os problemas que envolvem os conceitos são conduzidos de modo repetitivo, autômato, sem contribuir para o desenvolvimento de novas formas de abordar situações novas, como questões não previstas;

c) Os laboratórios utilizam materiais que não se adequam à realidade escolar, sofisticados. Isso limita o processo de verificação dos dados a "receitas" que não contribuem com a atividade investigativa;

d) O currículo, geralmente, é muito amplo: muitos temas devem ser abordados em pouco tempo. Isso impede uma apropriação em profundidade dos conceitos.

Quanto preparação pedagógica geral, McDermott (1990) acrescenta que se os métodos de ensino não são estudados no contexto em que serão implementados, disso resulta que os professores quando forem para a sala de aula podem não saber identificar os aspectos essenciais e nem adaptar para seus próprios contextos de ensino aquilo que lhes foi apresentado em termos abstratos. A autora sugere algumas maneiras que poderiam conter esses impactos negativos na formação de professores de Física (MCDERMOTT, 1990). Uma primeira e principal sugestão, segundo a autora, seria a de estruturar currículos específicos dirigidos à formação de professores. Com isso, é possível (MCDERMOTT, 1990, p. 739):

- Enfatizar os conteúdos que o professor vai ensinar;

- Solidificar a compreensão fenomenológica da física;

- Familiarizar o futuro professor com o processo de raciocínio que subjaz à construção dos conhecimentos;

- Ajudar os futuros professores a expressarem seu pensamento com clareza;

- Permitir ao futuro professor conhecer as dificuldades previsíveis que os alunos encontram ao estudar a matérias.

Portanto, instituições de ensino que oferecem uma Licenciatura em Física com um currículo separado ao do Bacharelado teriam melhores condições de promover uma formação inicial mais adequada pois, o foco das aulas [teoricamente] estaria na formação de um profissional específico (BRASIL, 2002).

\subsection{Em defesa de uma nova orientação epistemológica de ensino e de formação}

As implicações das epistemologias positivistas e da racionalidade técnica na formação e na prática de professores Ciência e de Física mostraram-se infrutíferas frente ao desafio de 
formar as massas ou de popularizar alguma educação científica. Então, o desafio imposto frente aos dilemas da formação e do ensino é o de romper com propostas conservadoras, tradicionais e simplistas de formação e de prática baseadas no modelo da racionalidade técnica. Portanto, é urgente a implementação de outras propostas de ensino e formação que sejam, preferencialmente, balizadas em percursos que focalizem nos aspectos de como o conhecimento é construído, ancorados em movimentos epistemológicos contemporâneos e que rejeitem o protagonismo de projetos normativos (SANTOS, 2005). Para isso, tais percursos devem:

1) Tomar como ponto de partida o ensino das ideias prévias dos alunos;

2) Centrar no sujeito o papel da atividade pela construção do conhecimento, substituindo o agir manipulativo pela atividade intelectual;

3) Levar em consideração no momento do ensino que o aluno aprende por mudanças no sistema cognitivo;

4) E incorporar no papel do professor o papel de facilitador da aprendizagem.

Esses percursos aproximam-se, portanto, de correntes na linha do construtivismo. Essas correntes, embora divirjam conforme a ênfase na direção do desenvolvimento - do individual para o social ou do social para o individual - radicam pedagogias que combatem radicalismos individualistas e compreendem o processo educativo como construção do saber e do sujeito. São pedagogias estruturadas a partir de propostas do tipo dialógicas entre quem aprende e quem ensina. Essas pedagogias na linha construtivista apoiam-se em teorias psicológicas que tiveram como principais precursores Piaget e Vygotsky.

As contribuições dos estudos de Piaget tiveram como pano de fundo as preocupações com uma epistemologia genética para a compreensão do desenvolvimento do conhecimento do sujeito coletivo da ciência. Entretanto, seus trabalhos passaram a valorizar mais a construção do conhecimento e do pensamento pelo próprio sujeito do que por influência social. Isso deu um particular significado à atividade interna do aluno, principalmente a operação lógica-matemática, na construção do conhecimento. Embora o objeto de estudo de Piaget não fosse o sujeito individual, seus trabalhos contribuíram para gerar conhecimentos significativos sobre o desenvolvimento cognitivo (teoria dos estágios), além da atividade auto estruturante do sujeito em construção e sobre os processos de equilibração/desequilibração causados por conflitos cognitivos (SANTOS, 2005). A contribuição dos trabalhos de Piaget desenvolveu perspectivas “cognitivo-construtivistas" (SANTOS, 2005, p. 33) que nortearam a valorização do aluno como sujeito psicológico. Essa perspectiva conduziu a uma ruptura com 
as orientações comportamentalistas, pois os erros dos alunos são vistos como parte construtiva do processo de ensino e aprendizagem.

$\mathrm{Na}$ construção do saber e do sujeito, Vygotsky valorizou, por sua vez, fatores socioculturais e interpessoais. Os trabalhos deste pesquisador atribuem um peso muito significativo à mediação da cultura, das relações sociais, do professor e dos pares na construção do conhecimento. Os estudos de Vygotsky propõem uma dimensão interpessoal do conflito cognitivo, o que dá visibilidade à relação de cooperação entre os pares, a modelização, a interação simbólica e a relação dialógica. Diferentemente de Piaget, que não tinha sua atenção voltada para a dimensão social da escola e da educação, Vygotsky valorizou muito essa dimensão social e, em geral, dos professores como mediadores da aprendizagem. Vygotsky propôs que depende destes atores o desenvolvimento da aprendizagem. (SANTOS, 2005). Dessa relação mediada é que os seres biológicos são transformados em seres históricoculturais, de modo que na relação com a cultura, com a linguagem e com o outro que nos constituímos seres humanos.

De modo geral, os percursos educativos na esteira do construtivismo têm também fundamentos no movimento epistemológico contemporâneo da construção do conhecimento, que já tem algumas décadas. Esse movimento tem por base pressupostos racionalistasconstrutivistas em que estão envolvidos pensadores como Bachelard, Popper, Kuhn, Lakatos, Feyerabend, etc. Tais pressupostos advogam que, para observar, a percepção não basta. Essa defesa propõe que não existem garantias do controle das ideias através de observáveis neutros, isto é, destituídos de qualquer componente teórico. Então, diferentemente do positivismo, os pressupostos racionalistas-construtivistas consideram que todo dado empírico é carregado de uma teoria, à priori, indispensável, que oriente a observação. Em outras palavras, todo dado de observação, para se tornar um dado científico, tem de ser uma construção da razão. Esses pressupostos epistemológicos ancoram a necessidade do erro como elemento constitutivo do conhecimento - doutrina da positividade do erro -. Com isso, alicerça a concepção de que a evolução do conhecimento faz-se por uma cadeia de erros e acertos, tão necessários uns como os outros no pensamento racional (SANTOS, 2005).

Neste sentido de construção do conhecimento, resultados de pesquisas e contribuições acerca dos problemas colocados pelo processo de ensino e aprendizagem, mesmo sendo específicos, não são contraditórios com os resultados trazidos pela nova psicologia educacional, pela Epistemologia e pela Neurociência. Os avanços nessas áreas e principalmente os da Neurociência (ANDERSON, 1997; ROTH, 1998; GUERRA, 2011) parecem apoiar as orientações construtivistas e, ao mesmo tempo, mostram as limitações dos 
modelos de transmissão e processamento de informação. Entretanto, os aportes teóricos que descrevem construtivismo diferem entre si. Em estudos atuais pode-se identificar algumas vertentes teóricas, dos quais se destacam três: o Construtivismo psicológico, o educacional ou pedagógico e ainda o filosófico (MASSABNI, 2011). O construtivismo pedagógico refere-se aquele orientador de práticas escolares que pode ser identificado tanto nos discursos quanto nos textos para a educação, por sua linguagem e seus propósitos, os quais são diferentes daqueles das teorias psicológicas que o embasam. O Construtivismo filosófico é referente a uma posição epistemológica sobre como o ser humano adquire conhecimentos. Alguns autores identificam a existência desta vertente em estudos e propostas educacionais, mas não nos discursos dos educadores (CARVALHO, 2001).

Isso demonstra que os fundamentos teóricos do Construtivismo pedagógico podem ser diversificados e confusos, justamente porque partem de uma mistura de teorias: as de Piaget, Vygotsky, Wallon, Ausubel, Gardner, Glasersfeld, Osborn (especialmente nos estudos em Ensino de Ciências) entre outros, dependendo do autor ou publicação consultada. Por exemplo, os Parâmetros Curriculares Nacionais de Ciências Naturais (Brasil, 1998), citam Piaget, Vygotsky e, da área de Ensino de Ciências (BRASIL, 2006), Osborn. Por esse motivo é importante ressaltar as ideias que são centrais de como as pedagogias na linha do construtivismo podem orientar a prática. De modo geral, a análise de alguns textos (ZABALA, 2003; GLASERSFELD, 1989) permite reunir as seguintes orientações:

- Considerar as ideias do aluno;

- Tornar o conteúdo significativo para o aluno;

- Respeitar e conhecer o nível de desenvolvimento do aluno (por exemplo, conhecendo as hipóteses que elabora);

- Desencadear o conflito cognitivo e/ou motivar o aprendiz para a solução de problemas conceituais;

- Valorizar atividades que favoreçam a construção de conhecimentos próprios do aluno e a disponibilidade para aprender a aprender;

- Não dispensar conhecimentos, apresentando-os prontos (formalizados);

- Estruturar o conhecimento em torno de conceitos e grandes ideias.

$\mathrm{Na}$ área de pesquisa em Ensino de Ciências, o referencial construtivista disseminou-se a partir dos anos 80 em estudos sobre o desenvolvimento de concepções científicas nas crianças, inspirados pelas investigações de Piaget. Atualmente há uma variedade de trabalhos em Ensino de Ciências identificados como construtivistas, de modo que o Construtivismo chega a ser considerado um paradigma nesta área (Osborne, 1996). O consenso construtivista 
(CACHAPUZ et al, 2005, p. 111) na área do ensino de ciências tem origem em investigações relativas a diferentes aspectos do processo de ensino e aprendizagem de ciências: dos conceitos, resolução de problemas, trabalho experimental ou atitudes em relação a e para com a Ciência (CACHAPUZ et al, 2005). Tal consenso reúne, todavia, três aspectos principais: a valorização das concepções prévias dos estudantes, a importância das interações entre indivíduo e objeto de conhecimento e a necessidade das interações sociais na construção do conhecimento (NOVAK, 1988; GIL-PÉREZ et al., 1999; CARVALHO, 2013). Em torno da Educação Científica e do Ensino de Ciências, investigações esforçam-se por construir um corpo coerente de conhecimentos específicos. Nessa direção, ocorrem esforços para se delimitar o que se entende por Construtivismo no Ensino de Ciência. Algumas definições nessa esteira de construtivismo sugerem, por exemplo, pensar o aluno como um cientista principiante (CACHAPUZ et al, 2005). Essa metáfora parece, segundo Cachapuz et al (2005), traduzir melhor a situação de aprendizagem:

\begin{abstract}
Com efeito, qualquer investigador sabe que quando alguém se junta a uma equipa de investigação, ele ou ela consegue alcançar com relativa rapidez o nível médio do resto da equipa. E isso não acontece por transmissão verbal, mas através do tratamento de problemas, em particular em áreas em que os colegas são especialistas. A situação muda é claro, quando os problemas são novos para todos os membros da equipa. Neste caso, o progresso - se é que existe algum - torna-se lento e sinuoso. A proposta de organizar a aprendizagem dos alunos como uma construção de conhecimentos corresponde à primeira das situações, quer dizer, a uma investigação orientada, em áreas perfeitamente conhecidas pelo diretor de investigação, aqui o professor, e onde os resultados parciais e embrionários obtidos pelos alunos podem ser reforçados, completados ou mesmo até questionados pelos obtidos pela "comunidade científica". (CACHAPUZ et al, 2005, p. 113)
\end{abstract}

A aproximação da aprendizagem das ciências ao fazer científico parece integrar coerentemente as contribuições teóricas do construtivismo, pois prevê a participação ativa dos alunos na construção do conhecimento. A proposta da construção do conhecimento em ciências aproximada a uma atividade com o tratamento científico dos problemas pode ser justificada uma vez que:

a) Dá mais sentido ao estudo e evita que eles se vejam imersos no tratamento de uma situação sem ter tido a oportunidade de formar uma primeira ideia motivadora acerca do assunto/situação;

b) O estudo qualitativo de situações problemáticas, tomando decisões — com a ajuda de necessárias pesquisas bibliográficas — ajuda a definir e delimitar problemas concretos. Esta atividade pode auxiliar o professor a conhecer as ideias dos alunos de maneira funcional; 
c) Possibilita a invenção de conceitos e a emissão de hipóteses (ocasião para usar as concepções alternativas para fazer previsões);

d) Pressupõe a elaboração de possíveis estratégias para a resolução de problemas, incluindo, quando apropriado, desenhos experimentais para verificar as hipóteses à luz da teoria;

e) Estratégias como a análise dos resultados, confrontando-os com os dados obtidos por outros alunos e com os da comunidade científica pode converter-se numa ocasião de conflito cognitivo entre distintas concepções (tomadas todas elas como hipóteses) e obrigar a conceber novas conjecturas e a reorientar a investigação;

f) Pode-se utilizar o novo conhecimento numa variedade de situações com vista a ser aprofundada e consolidada.

Neste momento cabe a reflexão sobre quais sentidos têm a aprendizagem como investigação orientada se os professores não tiverem ainda a oportunidade de vivenciar a experiência investigativa em sua própria formação inicial? Isso significa que a formação de professores seja alvo de reestruturações que permitam a construção de um corpo de conhecimento de Ensino de Ciências e que o sentido seja o da superação da transmissãorecepção de conhecimentos (CARVALHO; GIL-PÉREZ, 2000).

\subsection{Um modelo de formação profissional na esteira de epistemologias modernas}

Em sua obra, Educando o Profissional Reflexivo, Schön (2000) propõe que para algumas categorias de profissões existem situações na vida do profissional que não são possíveis resolver através da técnica derivada da pesquisa aplicada. Essa é uma crítica ao paradigma de educação profissionalizante baseado no racionalismo técnico que, apesar de não estar direcionada especificamente a formação de professores, se adequa perfeitamente a esta categorias de profissionais. De acordo com o autor, os currículos de formação normativos, dicotômicos (ciência aplicada versus ciência de base) e com os estágios situados no final do processo tornaram-se inócuos (SCHÖN, 2000). Esse tipo de currículo revigora o pensamento de que os conhecimentos são puramente teóricos e proposicionais. Diante disso, a questão fundamental que Schön (2000) tenta tocar em sua obra é o de delinear que tipo de formação é mais adequado a uma epistemologia que forme profissionais competentes e que ligue, ao 
mesmo tempo, a teoria e a prática em torno de um paradigma eficaz de formação profissional. Assim, os trabalhos de Schön (2000) acabam girando em torno de temas pertinentes e atuais, como o conceito de profissional eficiente, a relação entre teoria e prática e da educação para a reflexão.

Para responder à sua questão, Schön (2000) penetrou na compreensão da atividade profissional através da observação das interações entre alunos e professores in loco na formação. A análise decorrente desse estudo evidenciou o valor epistemológico da prática e, ao mesmo tempo, revalorizou o conhecimento que nasce da prática inteligente e refletida dos profissionais. Segundo o autor, este conhecimento é contextualizado e alinha-se ao lado dos conhecimentos declarativos e processuais desenvolvidos pela epistemologia científica e técnica. Desta maneira, por detrás da epistemologia da prática do conhecimento, está uma perspectiva construtivista e situada, contrapondo-se a visões que subjazem ao racionalismo técnico. Resta compreender como a aprendizagem desse conhecimento pode ser gerada nos programas de formação profissional, uma vez que a aprendizagem que se gera na prática é um elemento formativo importante.

A ideia presente na obra de Schön (2000) é que quando alguém aprende uma profissão, é iniciado em determinadas convenções, dificuldades, exigências, limitações, saberes e linguagens específicas, sistema de valores, conhecimentos de casos típicos, esquemas de pensamento e de ação. A iniciação na profissão pode assumir formas diferentes: pode-se aprender sozinho, pode-se aprender junto de um profissional - numa relação que Schön identifica como a de aprendiz e artesão - ou em um estágio orientado por um profissional, designado como coach (mentor, professor-formador, etc.). O coach, no sentido constantes no trabalho de Schön (2000), é aquele que organiza situações em que o aluno possa praticar e confrontar-se com problemas reais cuja solução implica reflexão, levantamento e verificação de hipótese, a experiência de cometer erros, consciência da necessidade do valor da ajuda dos outros e do aperfeiçoamento constante. Esta é a situação da prática orientada, cujo objetivo é a iniciação à profissão através da verificação de alternativas possíveis para agir em certas situações, além da imitação. A imitação também é colocada por Schön (2000) como um processo construtivo, já que a atuação do formador é interpretada e conceitualizada pelo formando. Este último interioriza-a como sua. Mas esse processo depende da atuação do formador ser positiva para o formando, proporcionando assim reflexão. A atuação do formador, para ser positiva ao formando, tem que contemplar uma estratégia pessoal, heurística, usando de experimentação e reflexão como elementos primordiais, além do 
formador ter de assumir uma postura empenhada. Desse modo, o papel do formador vai além da de facilitador da aprendizagem.

Nesta proposta de formação, além do formador ser parte fundamental do processo, a prática se constitui como uma fonte de conhecimento. A experimentação e a reflexão que a prática permite são os momentos privilegiados da integração de competências. Nesse momento, o aluno tem oportunidade de representar mentalmente a qualidade do produto final, apreciar a própria capacidade de agir e, ao mesmo tempo em que ocorre o diálogo entre formador e formando, clarificar o sentido da ação. Isso não exclui, diga-se de passagem, o ensino tradicional, expositivo, a aprendizagem de regras, fatos e conceitos fundamentais. Mas, sempre que possível, o formador deve retornar à demonstração, questionamento, aconselhamento e espírito crítico perante os alunos.

Logo, ao professor, formador, orientador, mentor ou coach cabe basicamente três funções diante da prática: abordar o problema que a tarefa coloca, escolher na sua atuação as estratégias formativas que melhor correspondem a personalidade e aos conhecimentos dos formandos com quem trabalha e tentar estabelecer com os alunos uma relação que propicia a aprendizagem. Quanto às estratégias formativas, o formador pode usar a experimentação em conjunto, a demonstração acompanhada por reflexão e a experiência e análise de situações homológicas. No bojo dessas estratégias, Schön (2000) propõe que o formador preconize: demonstrações acompanhadas de comentários sobre os processos seguidos, esclarecimentos sobre as contribuições que os vários domínios do saber podem trazer para o problema, crítica, reapreciação, valorização da verbalização do pensamento como reflexão da ação e diálogo com a situação, encorajamento, instruções, sugestão, iniciação do formando à linguagem própria da formação e nas formas de pensamento e de atuação características da profissão em questão. Para tanto, a proposta de Schön (2000) implica em algumas considerações: as situações práticas não devem portar muitos riscos; os profissionais, a quem os formandos irão recorrer, devem ser profissionais competentes; as relações entre formador e formando não podem se constituir de mecanismos de defesa entre os pares.

É importante salientar a visão de Schön (2000) sobre o papel do estágio. Este não pode ser considerado, segundo o autor, um aspecto menos importante nos currículos. O estágio deve ser reconhecido e os professores responsáveis por essa etapa devem ser escolhidos entre os melhores elementos do corpo docente. Schön (2000) adverte para o fracasso do estágio quando este se afasta muito das condições normais ou reais, em que os alunos fiquem demasiado sobrecarregados. 
Embora as propostas de Schön sejam promissoras ao trazer à luz a sala de aula como um contexto complexo e imprevisível, cujo os conhecimentos profissionais são gerados partindo da problematização e da reflexão - em substituição ao paradigma da racionalidade técnica e instrumental que concebe a sala de aula como um ambiente previsível e estático seu modelo foi alvo de críticas, principalmente frente a modelos de formação que propõem outras concepções do ser professor. Dentre os vários modelos de formação trazidos por diversos autores, pode-se citar o modelo da racionalidade crítica e do paradigma reflexivo (CONTRERAS, 2002; ZEICHNER, 19963; TARDIF, 2002). Mas, para os propósitos desta pesquisa, as ideias trazidas por Schön (2000) mostraram-se adequadas e suficientes. 


\section{A natureza da pesquisa}

Para ser possível investigar como é o processo formativo proporcionado por uma instituição de ensino na Licenciatura em Física sob o ponto de vista de alguns de seus egressos, o estudo foi separado em dois momentos diferentes de tomada de dados. O primeiro momento foi o da análise de documentos oficiais a respeito da legislação brasileira sobre a formação de professores e as estatísticas de concluintes de cursos de licenciatura em física no país. Além disso, também foram feitas análises dos documentos norteadores da Licenciatura investigada, tais como os projetos políticos pedagógicos e demais documentos que pudessem revelar o processo e as mudanças ocorridas nessa licenciatura. O segundo momento consistiu da obtenção de dados empíricos através da análise das informações trazidas nas entrevistas dos profissionais egressos da licenciatura em questão sobre o processo formativo vivenciado.

Através dos dados trazidos por essas duas fontes de informações, será possível comparar as ambições constantes nos documentos oficiais com as ambições dos egressos quanto à formação e apontar, de acordo com o olhar dos egressos, os parâmetros positivos de formação.

Assim, a configuração do estudo proposto neste trabalho é a de natureza qualitativa. Isso significa que, em linhas gerais, esse estudo não procurou enumerar ou medir os eventos estudados, nem empregar somente instrumental estatístico na análise dos dados. $\mathrm{O}$ estudo partiu de questões ou focos de interesses amplos, que foram se definindo à medida que a pesquisa se desenvolveu. Envolveu a obtenção de dados descritivos sobre os sujeitos, o ambiente, o contexto e os processos interativos pelo contato direto da pesquisadora com a situação estudada. Dessa maneira, buscou-se compreender os fenômenos segundo a perspectiva dos próprios sujeitos, ou seja, dos participantes da situação em estudo, que no caso são professores formados pelo Instituto de Física da USP.

O princípio norteador no início dessa pesquisa foi o de buscar as visões e opiniões dos alunos e ex-alunos sobre o curso de Licenciatura em Física oferecido pelo IFUSP. Através dos dados trazidos pelos sujeitos, propor uma descrição de como se dá o processo formativo no Instituto que nos ajude a compreender o processo. A escolha pelo Instituto de Física da USP como o ambiente do nosso estudo se deu pelo fato de que, de acordo com os dados sobre o número de formados por ano associado ao processo histórico de construção do currículo do curso, assumimos a hipótese de o curso ser considerado como um caso de sucesso em meio a cursos de Licenciatura em Física no país. Ao longo da pesquisa, foi possível verificar que a 
formação do currículo, as disciplinas, as ações de âmbito institucional e, principalmente, dos próprios professores nas disciplinas marcaram nossos sujeitos. Com os dados obtidos das entrevistas e por meio da análise desses dados pudemos definir nosso objetivo mais específico, que é o de compreender de que maneira o curso de Licenciatura em Física oferecido pelo IFUSP se posiciona de acordo com a proposta curricular e o Projeto Político Pedagógico. Com base nisso, atingir o objetivo geral de estabelecer parâmetros positivos de formação. Dessa maneira, neste estudo, diversamente de um estudo quantitativo, a pesquisadora não conduziu seu trabalho a partir de um plano estabelecido a priori, com hipóteses claramente especificadas e variáveis operacionalmente definidas. As hipóteses foram sendo construídas conforme a pesquisa foi se desenvolvendo e a pesquisadora se aprofundando no campo de estudo sobre o processo histórico de construção do currículo do curso e se envolvendo com o ambiente de pesquisa. Convém mencionar que a estratégia de investigação qualitativa assume alguns traços essenciais que podem ser resumidas em cinco características gerais (BOGDAN; BIKLEN, 1994):

a) Na investigação qualitativa, a fonte direta de dados é o ambiente natural, constituindo o investigador o instrumento principal;

b) A investigação qualitativa é descritiva;

c) Os investigadores qualitativos interessam-se mais pelo processo do que simplesmente pelos resultados ou produtos;

d) Os investigadores qualitativos tendem a analisar os seus dados de forma indutiva;

e) O significado é de importância vital na abordagem qualitativa.

Posto isso, é interessante frisar que nesta pesquisa todas as características gerais que resumem a investigação qualitativa foram contempladas ao longo do seu desenvolvimento. Nesse sentido, nesta pesquisa qualitativa, o olhar da pesquisadora estava voltado para a compreensão ou a descrição das ações dos sujeitos em determinados contextos. Essa compreensão ou descrição emergiu dos dados que, no contexto deste trabalho, são as entrevistas registradas e transcritas. O foco não se voltou para os resultados, se a formação inicial foi boa ou ruim, por exemplo, mas para o processo vivenciado pelos sujeitos. As hipóteses e as teorias que alicerçam o trabalho foram extraídas a partir do que os dados revelaram nas perspectivas trazidas pelos próprios sujeitos e como eles deram significado às experiências vividas.

Portanto, em função da natureza do problema que buscamos estudar, que é o da formação inicial oferecida pelo IFUSP, e das questões e objetivos que orientaram a investigação - compreender como se dá o processo formativo nessa instituição - a opção pelo 
enfoque qualitativo se tornou a mais apropriada. Lidamos com problemas de cunho exploratório, numa perspectiva descritiva e o que se buscou foi o entendimento do fenômeno como um todo, na sua complexidade, que são justamente as características mais apreciadas na pesquisa qualitativa.

\subsection{Os sujeitos ou informantes}

A escolha por ex-alunos e ex-alunas, egressos do curso de Licenciatura em Física como principal fonte de dados, teve como pressuposto a compreensão de que esses sujeitos contribuiriam com informações à luz de diferentes perspectivas e enfoques. Isso significa que, nesse processo, o olhar do entrevistado foi valorizado de forma que a experiência objetiva e subjetiva dos sujeitos se constituiu como nosso principal dado.

O critério de escolha dos sujeitos foi ter atuado como professor de física em escola ao se formar, além de ter se formado pelo Instituto de Física da USP, obviamente. Esses critérios tiveram como princípio o de buscar as informações das pessoas que viveram a realidade pragmática da profissão e, principalmente, do início da carreira como professor. Dessa maneira, era esperado que, ao falar diretamente sobre suas formações iniciais, os sujeitos revelassem, sob suas perspectivas, como elas aconteceram no cerne do lócus da pesquisa.

A busca pelos informantes ou sujeitos aconteceu por meio de dois métodos. O primeiro foi por meio da lista de alunos formados entre os anos de 2012 e 2016. Essa lista foi fornecida pela Comissão de Graduação do Curso de Licenciatura em Física. De posse da lista, iniciou-se o processo de contato por e-mail com esses alunos egressos. O teor do $e$-mail era o de um convite para contar um pouco sobre a Licenciatura em Física vivenciada no IFUSP. No entanto, o número de respostas foi extremamente baixo se comparado com o número total de pessoas contatadas. Somente um dos entrevistados retornou contato dessa primeira tentativa, sendo ele o nosso entrevistado de codinome Fermi.

O segundo método se deu através do contato direto com os sujeitos ou por indicação (método conhecido como Snowball). Isto é, através de convites feitos a pessoas da rede de relações da pesquisadora. Isso só foi possível depois que a pesquisadora passou a "vivenciar" o ambiente de pesquisa. A pesquisadora, que vinha de outra instituição de ensino superior localizada no interior do Estado de São Paulo, ao iniciar a pesquisa, não tinha contato com outras pessoas além do seu próprio grupo de pesquisa. Além de começar a frequentar as disciplinas da pós-graduação, ela passou a acompanhar algumas aulas da graduação como 
monitora. Também passou a frequentar reuniões, espaços de convivência, etc. Isso possibilitou que surgisse aquela rede de relações no Instituto. Apesar de mais demorado, esse método foi o mais frutífero. Essa abordagem é preconizada como um traço ou viés de investigação própria da pesquisa qualitativa ou etnociência, já que permite obter os dados diretamente da fonte, ambiente natural ou lócus de pesquisa (MINAYO, 2001). A busca por informantes através desse método rendeu um total de sete sujeitos.

Todos os sujeitos, como desejado, tinham dois pontos em comum: a formação inicial em Licenciatura em Física pelo IFUSP e a atuação, ao menos no início da carreira, em escolas do Ensino Básico - Fundamental ou Médio - públicas ou privadas. O ano de conclusão da graduação em Licenciatura em Física abrange um espectro amplo de tempo entre o sujeito formado há mais tempo e o sujeito formado recentemente (ou em vias de se formar), de quase 40 anos. Esse fato foi interessante, pois, como será discutido nas análises das entrevistas, possibilitou tomar contato com o cenário traçado por pelo menos um representante relativo a cada mudança estrutural do currículo do curso estudado nesta pesquisa. Na Tabela 1 são apresentados os sujeitos, os codinomes utilizados na pesquisa e o ano de conclusão da graduação:

Tabela 1 - Codinome dos sujeitos entrevistados e o ano de conclusão da graduação

\begin{tabular}{|l|c|c|}
\hline & Ano de Conclusão da Licenciatura & Codinome \\
\hline Sujeito 1 & 1985 & Herschel \\
\hline Sujeito 2 & 1995 & Heisenberg \\
\hline Sujeito 3 & 2002 & Maxwell \\
\hline Sujeito 4 & 2003 & Feynman \\
\hline Sujeito 5 & 2013 & Fermi \\
\hline Sujeito 6 & 2014 & Planck \\
\hline Sujeito 7 & 2016 & Gauss \\
\hline Sujeito 8 & 2018 & Mayer \\
\hline
\end{tabular}

Dos 8 sujeitos entrevistados para esta pesquisa, haviam duas pessoas do gênero feminino e os demais, do gênero masculino, mas esse dado pareceu não influenciar no conteúdo dos dados. Além disso, apenas uma informante não havia concluído a Licenciatura em Física na época da entrevista. Como consequência, até o momento da entrevista, ela não havia vivenciado a experiência em a sala de aula na escola básica como professora de Física. Entretanto, resolvemos manter seu depoimento pois, com ele foi possível obter informações 
importantes relativas à última mudança curricular sofrida pela Licenciatura em Física do IFUSP e, assim, traçar um cenário interessante da licenciatura.

Seria quase impossível, de acordo com os objetivos desta pesquisa, interpretar as falas dos sujeitos sem antes compreender qual o contexto que moldura o texto de cada um dos entrevistados. A compreensão de contexto atribuída nesta pesquisa ${ }^{4}$ é a situação históricasocial de um texto. Essa situação envolve elementos tanto da realidade do autor, quanto do receptor (no caso, o leitor ou pesquisador).

\subsection{As entrevistas}

Como o objetivo geral da pesquisa é o de compreender como é a formação de professores de Física que o Instituto de Física da USP oferece, na visão dos ex-alunos formados por esse instituto, utilizamos como principal instrumento de produção de dados as entrevistas abertas centradas na temática do percurso formativo na Licenciatura em Física vivenciado pelos sujeitos.

No contexto desta pesquisa, as entrevistas abertas aconteceram como uma conversa presencial entre o sujeito e a pesquisadora. A escolha pelas entrevistas presenciais, face-aface, como método para coleta de dados, está associada à expectativa de que é mais provável que os pontos de vista dos sujeitos entrevistados sejam mais bem expressos nessa situação, com um planejamento aberto, do que em uma entrevista padronizada ou em um questionário.

No encontro entre a pesquisadora e os entrevistados, os sujeitos foram convidados a falar livremente sobre a temática envolvida. Isso teve a finalidade de que fossem relatados os elementos marcantes e centrais do processo de formação como professor de física proporcionado pelo IFUSP e vivenciado pelos sujeitos. Para auxiliá-los nessa viagem reflexiva através da trajetória de formação, foi utilizada, no momento da entrevista, a grade do curso da licenciatura. As entrevistas foram todas gravadas em áudio e, posteriormente, transcritas, integralmente, uma a uma. Elas aconteceram em um período de um ano, entre março de 2017 e março de 2018, com duração entre 30 e 45 minutos cada uma. Das oito entrevistas realizadas, duas delas ocorreram através de meios digitais. Mas, apesar de ter ocorrido por meio de videoconferência, essas entrevistas não fluíram tanto quanto as presenciais. Essa impressão foi confirmada depois, quando as entrevistadas foram analisadas e percebeu-se que esses sujeitos comentaram menos sobre alguns pontos em relação aos outros

\footnotetext{
${ }^{4}$ Termo emprestado da compreensão dada pela Teoria da Análise do Discurso
} 
entrevistados. Uma hipótese para essa diferença é o fato de ocorrerem interferências externas no momento da entrevista por videoconferência, que não são as mesmas no ambiente do entrevistado e do entrevistador, o que pode gerar ruídos. Além disso, parece que as entrevistas presenciais proporcionam um momento mais confortável, os entrevistados pareceram falar mais e mais livremente.

A possibilidade da viagem pela grade do curso através da memória sobre a trajetória de formação, que vai desde a escolha pela Licenciatura em Física até o início da atuação na escola, concedeu às entrevistas a característica de entrevistas-narrativas (MINAYO, 2001). Esse tipo de entrevista visa encorajar e estimular o sujeito, entrevistado ou informante, a contar algo sobre algum acontecimento importante da sua vida e do seu contexto social, tendo como base a ideia de reconstruir acontecimentos sociais a partir do ponto de vista dos informantes.

Apesar de as entrevistas serem abertas, elas seguiram um roteiro. Esse roteiro era constituído por um conjunto de temas a serem contemplados no momento da entrevista. Essa estrutura balizadora de uma entrevista é conhecida como roteiro invisível (MINAYO, 2001). O roteiro invisível, apesar de ser definido previamente, não tem condição de estanque. A ordem dos temas não obedece a uma sequência fixa e rígida, muito menos as perguntas. A importância dessa condição, tal como aponta Minayo (2001), reside em possibilitar que os assuntos sejam frequentemente determinados pelas próprias preocupações, relevâncias e ênfases que o entrevistado dá ao assunto. O roteiro foi elaborado visando orientar de maneira lógica a entrevista, mas não cronológica, com ordenação temporal para os temas emergirem na entrevista, ou hierárquica um tema mais importante que outro. Todas as entrevistadas transcritas passaram por um longo e - diga-se de passagem - exaustivo processo de leitura e análise. O objetivo foi o de construir as dimensões de análise que constituíram os dados a serem analisados.

\section{Análise documental: o caso USP}

A proposta deste capítulo é a de recuperar algumas das principais mudanças ocorridas no currículo da Licenciatura em Física oferecida pelo Instituto de Física da USP - IFUSP entre os anos 1990 e 2015 através da análise dos Projetos Políticos Pedagógicos - PPP da Licenciatura em Física em questão, de outros documentos relevantes e dos currículos do curso 
entre 1980 até 2015. O objetivo é o de apresentar indícios que justifiquem o pioneirismo da instituição em termos de currículo.

\subsection{0 caso USP}

A média de concluintes, por ano, das Licenciaturas em Física no Brasil pode ser um indicativo de um cenário pouco animador acerca desses cursos de formação de professores. Das cerca de 115 instituições públicas que oferecem essa modalidade de formação no país, que somam um total de aproximadamente 250 cursos, formam-se apenas 1570 alunos, em média, por ano. Esse dado nos fornece uma média de 14 concluintes por ano por instituição de ensino superior e cerca 6 alunos formados por ano por curso (dados dos anos 2013 a 2016). Com a média de 40 vagas oferecidas por curso de Licenciatura em Física no país, isso fornece um percentual de $15 \%$ de formados apenas. Destoando desse quadro traçado sobre o número de concluintes nas licenciaturas em Física, desponta o caso da Universidade de São Paulo USP. De 2000 a 2016, o curso oferecido pelo Instituto de Física - IF (campus São Paulo) formou cerca de 60 alunos por ano, o que fornece uma média de 30 alunos formados em cada período - no diurno e no noturno - por ano. Como essa Instituição oferece um total de 110 vagas entre os dois períodos, portanto quase $50 \%$ dos ingressantes conseguem concluir o curso. Mas nem sempre a taxa de formados no Instituto foi assim. Esse contingente expressivo (comparado com a média nacional) parece não ser fruto do acaso. É um indicativo de sucesso que deve ser analisado com base no processo de construção do currículo do curso que desde 1993 sofreu importantes readequações curriculares que merecem nossa atenção.

O período pós-militar no Brasil colocou a educação no centro das preocupações políticas que visavam, dentre outras coisas, a mudança dos objetivos educacionais. Em meio a esse cenário, em 1992 nasce a nova Licenciatura em Física pelo IFUSP, em um período visto como favorável a reformas. No cenário compreendido pela transição para a democracia, iniciada em 1980, afloraram as discussões acerca das políticas educacionais no país que enfatizaram a função social da escola. Alicerçada nessas discussões, começou a ser elaborada a nova Lei de Diretrizes e Bases da Educação Brasileira (LDB). A nova LDB, promulgada em 1996, visava substituir a primeira, que durava mais de 30 anos, e teve dentre suas propostas, a eliminação do caráter propedêutico do Ensino Médio. Isso significou considerar essa etapa da educação como a final. Como consequência, a escola passou a ser repensada para buscar outro 
significado que não só o de preparar o aluno para o vestibular ou para o trabalho. Concomitantemente à elaboração da LDB 9.394/96, o Brasil trabalhou na criação de seus Parâmetros Curriculares Nacionais (PCN). O processo de elaboração dos PCN começou em 1995 e visava estabelecer diretrizes para os currículos da Educação Infantil e do Ensino Fundamental ( $1^{\mathrm{a}}$ a $8^{\mathrm{a}}$ série). O PCN pretendia servir como referencial nacional, seja para a prática educacional, seja para as ações políticas no âmbito da educação. Na esfera dessas reformas, buscava-se organizar e ordenar os currículos e o ensino no Brasil. Nesse bojo, a política de formação de professores, bem como a concepção de trabalho docente sofreram importantes alterações.

O período compreendido pelas décadas de 1970, 1980 e 1990 experimentou também o crescente embate entre as diferentes concepções de educação, de ensino e aprendizagem e de formação profissional. Dentre algumas pesquisas com grande repercussão, principalmente na formação de professores, estão os estudos que focalizam nos motivos para o fracasso escolar e que acabam atribuindo ao professor e sua formação inadequada a culpa por esse fracasso. Assim, começa a ser crescente também nesse período a onda de autocrítica das instituições de ensino superior frente ao desprestígio que as atividades didático-pedagógicas possuíam em relação às de pesquisa na universidade. Como consequência, começam a despontar nas instituições de ensino superior tentativas de romper com a tradição iniciada no país na década de 1930, quando os primeiros cursos de formação de professores foram criados.

O modelo tradicional para a formação de professores vigente no Brasil desde então, se baseava no currículo normativo. Esse currículo concebe que o futuro professor deveria frequentar primeiramente o curso normal ao bacharel por um período de três anos e só depois, no último ano, frequentar as disciplinas de cunho pedagógico. Esse modelo, apelidado de 3+1, vigorou ao longo de todo o século XX. Com grande aceitação pelos professores universitários vinculados às disciplinas pertencentes ao campo de conhecimento da área específica, nas licenciaturas em Física, o modelo era difundido. Os poucos alunos que optavam pela Licenciatura, o faziam com o olhar de uma habilitação suplementar ao Bacharel. Um dos efeitos do modelo de formação $3+1$ podia ser medido através das altas taxas de evasão e da diminuição da procura por cursos de licenciaturas. Uma compreensão da relação causal entre evasão/baixa procura pela licenciatura e o modelo $3+1$ pode ser feita ao concordarmos que para um aluno tornar-se professor, ele deve se submeter antes a toda carga de disciplinas da formação do bacharel. Isso pode ter um efeito negativo, já que a identidade curricular do Bacharelado é diferente da Licenciatura. O contato tardio com os aspectos próprios da profissão de professor e o exaustivo processo formativo pelo qual o futuro professor era 
submetido acabavam por desanimá-lo a prosseguir o curso (TARDIF, 2002). O contrário também poderia acontecer - aquele aluno que viria a se tornar um professor poderia ser cooptado para a pesquisa na Física. A estrutura curricular do Quadro 1 pertence à Licenciatura em Física oferecida pelo IFUSP durante a década de 80. Ela é um exemplo de uma proposta baseada no modelo $3+1$.

Quadro 1 - Estrutura Curricular da Licenciatura até 1993

\begin{tabular}{|c|c|c|c|}
\hline Período & Física & Física + Metodologia & Educação \\
\hline \multirow{7}{*}{$\begin{array}{c}\text { Núcleo Básico } \\
\text { Comum (a todos os } \\
\text { alunos do IFUSP) - } \\
\text { Duração de } 3 \text { anos } \\
\text { ou mais }\end{array}$} & Física I, II, III e IV & & \\
\hline & Física Moderna I e II & & \\
\hline & Física Aplicada & & \\
\hline & Física Matemática I & & \\
\hline & Evolução dos Conceitos & & \\
\hline & $\begin{array}{c}\text { Estudos dos Problemas } \\
\text { Brasileiros }\end{array}$ & & \\
\hline & $\begin{array}{l}10 \text { Disciplinas oferecidas } \\
\text { pelo IQ e IME }\end{array}$ & & \\
\hline \multirow{4}{*}{$\begin{array}{l}\text { "Especialização" - } \\
\text { Duração de } 2 \text { anos }\end{array}$} & & Tecnologia do Ensino & Psicologia da Educação I e II \\
\hline & & $\begin{array}{c}\text { Instrumentação para o Ensino } \\
\text { I e II }\end{array}$ & Prática de Ensino I e II \\
\hline & & & $\begin{array}{l}\text { Estrutura e Funcionamento do } \\
\text { Ensino do } 2^{\circ} \mathrm{Grau}\end{array}$ \\
\hline & & & $\begin{array}{l}\text { Estudos de Problemas } \\
\text { Brasileiros I e II }\end{array}$ \\
\hline
\end{tabular}

Fonte: Hamburguer (1981, p. 5).

A estrutura curricular acima é um exemplo de uma proposta alicerçada no modelo $3+1$. Como se pode observar, o aluno que desejasse tornar-se professor teria seu primeiro contato com as disciplinas de cunho pedagógico ou disciplinas relacionadas a aspectos da profissão tardiamente. Esse currículo propõe 19 disciplinas ${ }^{5}$ obrigatórias e mais 5 disciplinas optativas, ficando com a disciplina de Prática de Ensino, oferecida pela Faculdade de

\footnotetext{
${ }^{5}$ Naquela época usava-se a denominação de "semestre" para cada disciplina oferecida, ou seja, enquanto nos referimos a um total de 19 disciplinas obrigatórias e mais cinco disciplinas optativas, os documentos originais fazem referência a 19 "semestres" obrigatórios e mais cinco "semestres" optativos. Nesses documentos estudados não se usa também terminologia "créditos".
} 
Educação - FE, toda responsabilidade pelo estágio, a ser realizado somente no último ano da grade. Um semblante da visão dicotomizada da época da relação teoria e prática. As únicas disciplinas da grade que possibilitam a interface entre o conteúdo e didática da física estavam a cargo da Tecnologia do Ensino e Instrumentação para o Ensino de Física. Cabe notar que essa grade não contempla a oferta de disciplinas de laboratório - as conhecidas Físicas Experimentais, que somente passaram a ser oferecidas como disciplinas na nova grade de 1993.

Nesse cenário de reformas educacionais, legitimadas através da nova LDB e do PCN, das diferentes perspectivas e concepções de ensino propostas por pesquisas e do crescente descontentamento diante do modelo de formação vigente para professores, algumas licenciaturas procuram saídas para os novos problemas que passam a surgir como reflexo da situação educacional do país e do mundo.

No caso da Licenciatura em Física oferecida pelo Instituto de Física da USP, já na década 80, muitos dos problemas enfrentados por conta da dicotomia entre a nova situação educacional que vinha surgindo e os velhos modelos de formação profissional, foram focos de discussões entre alunos e professores do Instituto. Ocorreram no IFUSP, nesse período, vários encontros com o objetivo de tornar evidentes as inquietações sofridas pelos membros da instituição. Os temas principais que emergiram das discussões desses encontros foram formalizados em um colóquio e compilados pela Professora Dra ${ }^{\mathrm{a}}$. Amélia Império Hamburger. Isso deu origem a um documento intitulado Licenciatura em Física na USP em Perspectiva (HAMBURGUER, 1981), mesmo título do colóquio. A questão sobre a falta de uma situação institucional e funcional claramente definida para a formação de professores de física pelo IFUSP aparece no documento, entretanto fica entendido que, pelo que consta no documento, o Instituto não tinha ainda naquele momento alguma proposta de solução. Isso sugere que existia um sentimento de insatisfação com o modelo de formação vigente naquele contexto institucional. Esse sentimento fica mais evidente à medida que o documento apresenta os outros problemas enfrentados principalmente pelos alunos, tais como:

- Cursos muito difíceis, com matemática e teorias profundas que não eram compatíveis com as demandas do ensino básico;

- Falta de ligação entre o que se ensinava na graduação com o que se ensinava no secundário (atual ensino médio);

- Didática das aulas na licenciatura que não se adequavam ao ensino secundário;

- Falta de exercícios e laboratórios;

- Dificuldade sofrida pelos alunos em relação aos pré-requisitos do curso. 
Uma interpretação possível da causa para essas queixas é a falta de uma identidade curricular para a formação de professores. Essa hipótese vai se confirmar com a proposta curricular de 1993, conforme será discutido mais adiante. No âmbito institucional, foram ainda apresentados outros dilemas e indefinições enfrentados pela Licenciatura em Física da USP:

- Várias unidades da USP (FE, IP, FFLCH, IME, IQ) são responsáveis pelo curso, mas não ocorre coordenação e diálogo entre elas;

- Falta de identidade em relação a qual profissão o curso forma: professor de ciências $\left(1^{\circ} \mathrm{Grau}\right)$ ou professor de física $\left(2^{\circ} \mathrm{Grau}\right)$ ?

- O curso se aproxima de uma licenciatura plena ou de uma licenciatura curta?

- Haveria ou deveria haver distinção entre a Licenciatura e o Bacharelado?

- Formavam-se Licenciados ou Pedagogos?

- O conteúdo (de Física) deveria ser ministrado separadamente da Metodologia, ou as disciplinas deveriam ser mistas?

- O número baixo de formados revelaria uma desvalorização da profissão pelo instituto?

Outra preocupação recorrente no documento é sobre a alta taxa de evasão e a baixa procura pela Licenciatura em Física. Entre as décadas de 1970 e 1980, a Licenciatura em Física pela USP experimentou sucessivas baixas em relação ao número de formados. Isso resultou em um número inexpressivo de professores formados por ano, o que não daria conta das demandas da rede pública e particular de ensino por professores de física (ao menos na Cidade de São Paulo). Como consequência, o ensino de Ciências Integradas (como era chamado o $1^{\circ}$ Grau, atual Fundamental II) ficaria a cargo de professores de biologia, no $2^{\circ}$ Grau (atual Ensino Médio), o ensino de Física acabava a cargo de professores de matemática, cursos cujo contingente de professores formados por ano eram mais expressivos. Uma observação: apesar dos problemas evidenciados acima terem sido extraídos de um documento elaborado em meados de 1980, em que foram ouvidos alunos e professores em reuniões ocorridas ao longo da década de 1970 e 1980, parece que muitos daqueles problemas apresentados ainda são bastante atuais nas licenciaturas em física do Brasil.

Todas as questões apontadas durante o Colóquio revelam a preocupação de professores e alunos do IFUSP de colocar em xeque a formação inicial oferecida. A essência das questões trazidas parece indicar uma desconfiança se o Instituto estaria, de fato, preocupado com a formação de professores de Física e se aquele currículo condizia com uma formação adequada. Isso é um prognóstico da reforma curricular de 1992, e implementada em 1993, que propunha o estabelecimento de uma identidade curricular para a Licenciatura em 
Física como carro-chefe da proposta. Assim, a partir de 1993, o Instituto de Física IF da USP passou a contar com um novo Projeto Político Pedagógico - PPP. Esse PPP da "nova Licenciatura do IFUSP”, como ficou conhecido, preconizou a oferta do curso de Licenciatura em Física com ingresso (via vestibular) separado do Curso de Bacharelado - em outras palavras, o aluno escolhia antes do vestibular qual dos cursos ele desejava fazer. À parte dos possíveis questionamentos sobre o preparo do vestibulando para escolher seu curso (e para saber a diferença entre licenciatura e bacharelado), a principal consequência positiva para a formação universitária foi que a licenciatura passou a dispor de grade curricular própria, com todas as disciplinas podendo ser específicas e modeladas segundo as necessidades de sua formação. Essa proposta buscava atingir a especificidade da formação do profissional Educador em Física, tentando romper com o modelo $3+1$ e buscando uma identidade curricular própria.

Quadro 2 - Estrutura Curricular da Licenciatura após 1993 - Diurno (apenas disciplinas obrigatórias)

\begin{tabular}{|c|c|c|c|c|c|c|c|c|}
\hline 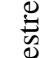 & \multicolumn{6}{|c|}{ Física e Ciências afins } & \multicolumn{2}{|c|}{ Educação } \\
\hline 1 & $\begin{array}{l}\text { Fundamentos da } \\
\text { Mecânica }\end{array}$ & $\begin{array}{l}\text { Introdução } \\
\text { às Medidas }\end{array}$ & Computação & & Cálculo I & $\begin{array}{l}\text { Geometria } \\
\text { Analítica }\end{array}$ & & \\
\hline 2 & Mecânica & $\begin{array}{l}\text { Termodinâ } \\
\text { mica I }\end{array}$ & Gravitação & Ótica & Cálculo II & $\begin{array}{l}\text { Probabilidade e } \\
\text { Estatística }\end{array}$ & & \\
\hline 3 & Eletricidade I & $\begin{array}{l}\text { Termodinâ } \\
\text { mica II }\end{array}$ & $\begin{array}{c}\text { Mecânica dos } \\
\text { Corpos Rígidos e } \\
\text { Fluidos }\end{array}$ & & Cálculo III & & $\begin{array}{c}\text { Introdução } \\
\text { aos Estudos } \\
\text { da Educação }\end{array}$ & \\
\hline 4 & Eletricidade II & Química II & $\begin{array}{l}\text { Laboratório de } \\
\text { Mecânica }\end{array}$ & & Cálculo IV & & $\begin{array}{c}\text { Psicologia da } \\
\text { Educação }\end{array}$ & \\
\hline 5 & $\begin{array}{c}\text { Oscilações e } \\
\text { Ondas }\end{array}$ & Relatividade & $\begin{array}{c}\text { Eletromag- } \\
\text { netismo }\end{array}$ & & & & Didática & $\begin{array}{c}\text { Estrutura e } \\
\text { Funciona- } \\
\text { mento da Educação }\end{array}$ \\
\hline 6 & Física Moderna I & $\begin{array}{c}\text { Laboratório } \\
\text { de } \\
\text { Eletromagne } \\
\text { tismo }\end{array}$ & & & & & & \\
\hline 7 & Física Moderna II & $\begin{array}{l}\text { Laboratório } \\
\text { de Física } \\
\text { Moderna }\end{array}$ & & & & & $\begin{array}{l}\text { Prática de } \\
\text { Ensino I }\end{array}$ & \\
\hline 8 & $\begin{array}{l}\text { Complementos de } \\
\text { Mecânica Clássica }\end{array}$ & & & & & & $\begin{array}{l}\text { Prática de } \\
\text { Ensino II }\end{array}$ & \\
\hline
\end{tabular}


Ocorreram nessa nova proposta uma pequena diminuição do total de créditos em disciplinas obrigatórias e o aumento substancial do número de créditos em disciplinas optativas. O objetivo desta mudança foi tornar o currículo mais flexível, reduzindo a carga horária em disciplinas obrigatórias e aumentando as optativas que deverão ser escolhidas dentro de um universo direcionado de alternativas.

A nova estrutura proposta para o currículo funciona da seguinte maneira: contém um número mínimo obrigatório de 118 créditos (o núcleo fundamental do currículo) comuns a todos os alunos da Licenciatura - Quadro 2 - e 44 créditos em disciplinas optativas. A oferta das disciplinas optativas é feita dentro de estruturas chamadas de Blocos. Essas disciplinas devem ser escolhidas pelos alunos dentro de cinco blocos distintos. Em cada bloco são exigidos determinados números mínimos obrigatórios de créditos a serem cursados, contabilizando um total de 28 créditos mínimos obrigatórios - Quadro 3 -. Os 16 créditos excedentes, também obrigatórios, para obtenção do diploma, são livres, ou seja, o aluno pode escolhe dentro dos Blocos, sem ter a preocupação de ter que ser de um bloco específico. Essa proposta visa garantir que o aluno escolha aquelas que estão relacionadas a profissão e que ainda, convenha ao seu perfil de aluno e de futuro profissional. Essa estrutura ancorada na proposta de uma dinâmica flexível é um indício da tentativa de ruptura com o currículo normativo. A seguir são apresentados os Blocos que compõem o currículo da Licenciatura em Física:

Quadro 3 - Estrutura dos Blocos

\begin{tabular}{|c|c|c|c|}
\hline Bloco & $\begin{array}{l}\text { Créditos } \\
\text { mínimos }\end{array}$ & & Exemplos \\
\hline $\begin{array}{l}\text { Instrumentação } \\
\text { para o Ensino de } \\
\text { Física }\end{array}$ & 12 & $\begin{array}{l}\text { Disciplinas de interface entre o } \\
\text { conteúdo e o ensino e são oferecidas } \\
\text { pelo Instituto de Física }\end{array}$ & $\begin{array}{l}\text { Elementos e Estratégias para } \\
\text { Ensino de Física, Propostas } \\
\text { Projetos de Ensino de Física } \\
\text { e } \\
\text { Produção de Material Didático. }\end{array}$ \\
\hline Integrador & 4 & $\begin{array}{l}\text { Propõe-se, com as disciplinas desse } \\
\text { bloco, a inter-relação entre a física e } \\
\text { aspectos históricos, sociais e } \\
\text { culturais. }\end{array}$ & $\begin{array}{l}\text { Evolução dos Conceitos da Física e } \\
\text { Tópicos de História da Física } \\
\text { Clássica. }\end{array}$ \\
\hline Temático & 8 & $\begin{array}{l}\text { Disciplinas que têm temas } \\
\text { abrangentes que são atravessados por } \\
\text { diferentes disciplinas da física. }\end{array}$ & $\begin{array}{l}\text { Física do Corpo Humano, Física do } \\
\text { Meio Ambiente e Meteorologia } \\
\text { Básica. }\end{array}$ \\
\hline Educação & 4 & $\begin{array}{l}\text { Disciplinas que ficam a cargo da } \\
\text { Faculdade de Educação, com foco na } \\
\text { educação geral, com a função de } \\
\text { complementar a formação oferecida } \\
\text { nas disciplinas do núcleo } \\
\text { fundamental. }\end{array}$ & \\
\hline Geral & $\begin{array}{c}\text { Sem } \\
\text { limite }\end{array}$ & $\begin{array}{l}\text { Disciplinas de Física e Matemática já } \\
\text { oferecida ao bacharelado, } \\
\text { selecionadas de modo a permitir o } \\
\text { aprofundamento do conhecimento do } \\
\text { aluno nessa área. }\end{array}$ & \\
\hline
\end{tabular}


Mantém-se um mínimo obrigatório de 2 créditos em disciplinas que discutem os problemas brasileiros, assim como na grade antiga, e é acrescido ainda um número de crédito para Monografia. Também entram para a grade as disciplinas de laboratório.

O Bloco Instrumentação para o Ensino de Física merece atenção, uma vez que as disciplinas que o compõem são aquelas que englobam aspectos da didática em Física. Tais disciplinas têm como objetivo a interlocução entre o conteúdo de Física e o conteúdo pedagógico e são oferecidas pelo próprio Instituto de Física. Porém, esse bloco não entra com disciplinas específicas obrigatórias na grade. $\mathrm{O}$ aluno deve escolher qual disciplina deseja cursar dentro daquelas disponíveis no semestre. Para obter o diploma era obrigatório que o licenciando completasse o mínimo de 12 créditos em disciplinas desse bloco. Esse bloco era composto pelas disciplinas de Elementos e Estratégias para o Ensino de Física, Propostas e Projetos para o Ensino de Física, Produção de Material Didático, O Computador e o Vídeo no Ensino de Física e Tecnologia do Ensino de Física I e II. Merece atenção a disciplina de Elementos e Estratégias para o Ensino de Física, pois por meio dela o docente procura colocar em evidência a Pedagogia através do contexto do Ensino de Física. Essa disciplina passou a fazer parte do núcleo comum obrigatório 10 anos mais tarde, na grade de 2006.

Comparando a grade proposta no Quadro 1 com a grade proposta no Quadro 2, constata-se que, através dessa última grade, o aluno da licenciatura consegue ter seus primeiros contatos mais diretos com os aspectos da profissão já no $3^{\circ}$ semestre. Esse é outro indício da tentativa de ruptura com o modelo $3+1$. Ressalta-se que mesmo as disciplinas do primeiro semestre já poderiam levar a um enfoque mais profissional, visto que passavam eram específicas da Licenciatura e estabelece disciplinas próprias da didática da Física.

Portanto, o projeto da nova Licenciatura em Física revela a antecipação da USP em relação à revisão sobre a sua própria concepção de educação, que a nova LDB de 1996 viria propor tornar explícito pelos institutos. Essa concepção é manifestada por meio do cuidado com a diferenciação entre os currículos da licenciatura e do bacharelado. Isso possibilitou que as disciplinas do núcleo fundamental comum da licenciatura em física pudessem ser oferecidas separadamente entre os cursos do IFUSP. Essa medida demandou, por exemplo, uma reestruturação das disciplinas como Física 1, Física 2, etc. (que passaram a ter nomes como Mecânica, Eletricidade e Magnetismo, etc.), e inserção de outras novas disciplinas de conteúdo a ensinar, tais como Óptica, Termodinâmica e Gravitação. Dessa maneira, o docente da disciplina que se dispusesse poderia direcionar as discussões para aspectos próprios da profissão, dando ênfases ou abordagens mais próprias para a licenciatura. Um exemplo disso é 
a disciplina de Gravitação, cuja ementa subjaz uma proposta de ensino através da história e da filosofia da física. Como Polati, Dias e Zanetic (2017) apontam:

\begin{abstract}
Estas disciplinas foram introduzidas no currículo para tentar apresentar a física como um empreendimento humano, como parte de um processo histórico que influencia e é influenciado pelas visões de mundo dos sujeitos que dele participa. Dessa forma, algumas disciplinas de Física do curso de Licenciatura se diferenciaram claramente da estrutura e dos conteúdos daquelas do Bacharelado. (POLATI, DIAS, ZANETIC, 2017, p. 76).
\end{abstract}

Essa disciplina de Gravitação exemplifica bem a preocupação do corpo docente da licenciatura em física do IFUSP com a formação mais adequada para futuro professor de física. Esse caso fica evidente quando analisamos a grade curricular: a disciplina é oferecida logo no segundo semestre do curso da licenciatura em física. Isso significa que, apesar da complexidade e da profundidade dos temas abordados, a disciplina incorpora elementos importantes da Física e outros ramos do conhecimento humanístico e cultural, como as artes, a história e a filosofia. Zanetic $^{6}$ (ZANETIC, 1989 apud POLATI, DIAS, ZANETIC, 2017), ao apresentar sua defesa acerca da necessidade desses elementos estarem presentes nas disciplinas de cursos de licenciatura em Física, argumenta que se a Física for ensinada envolvendo elementos da história e filosofia da ciência ela pode promover uma formação cognitiva e intelectual que vai além da formação técnica ou formulista (ZANETIC, 1989 apud POLATI, DIAS, ZANETIC, 2017, p. 72). Dessa forma, o aluno, ao se deparar com aqueles elementos logo no início do curso, é auxiliado a romper obstáculos didáticos e epistemológicos, o que pode favorecer uma formação científica mais conectada às disciplinas de conteúdos físicos e aos dos saberes pedagógico. Por conseguinte, propicia o desenvolvimento de uma visão integrada dos conhecimentos físicos e epistemológicos.

A implementação do novo currículo da Licenciatura em Física da USP, com propostas de mudanças estruturais e forma diferenciada de ingresso, revela a tentativa de solução de problemas que viriam a ser discutidos no âmbito nacional somente anos mais tarde, com o parecer do Conselho Nacional de Educação de 2001 (CNE/CP n ${ }^{\circ}$ 9/2001). Dois dos problemas discutidos no documento da CNE, a supracitada evasão e a baixa demanda pelas licenciaturas, principalmente em cursos de formação de professores de física que somente com esse documento as discussões desses problemas "considerados históricos nos cursos de licenciatura" (CNE, 2001) passam a ganhar destaque nas instituições do país. A proposta curricular implementada no novo currículo passa a revelar alguns efeitos: ano após ano o

\footnotetext{
${ }^{6}$ ZANETIC, J. Física também é cultura. Tese (doutorado). Faculdade de Educação, Universidade de São Paulo, 1989.
} 
Instituto de Física começa a registrar o aumento da permanência e do número de formados na Licenciatura em Física. O aumento do número de concluintes fica evidente no Gráfico 1, em que se mostra um levantamento dos números de concluintes da licenciatura em Física pelo IFUSP entre os anos de 1997 a $2016^{7}$.

Gráfico 1 - Evolução do número de concluintes da Licenciatura em Física (1997 a 2016).

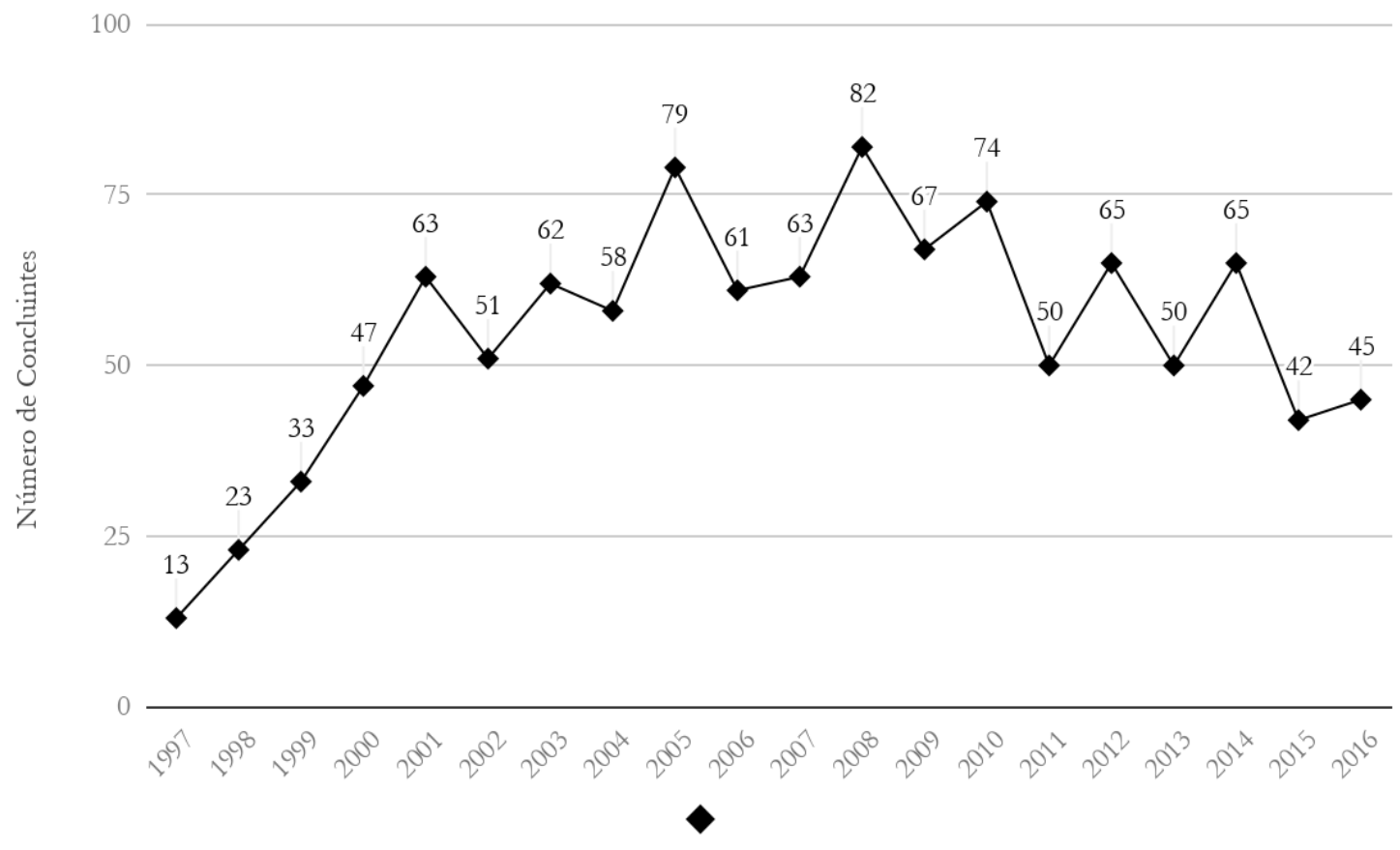

Fonte: Seção de alunos do IFUSP, 2018.

No entanto, a análise das mudanças ocorridas na Licenciatura em Física no decorrer dos anos não pode descolar tal empreendimento de seus atores. A reestruturação do curso demandou não somente modificações oficiais do currículo, mas também modificações nas práticas e na cultura de formação profissional. Isso exigiu envolvimento e comprometimento dos docentes do IFUSP. Muitos professores e professoras que possuíam alguma espécie de vínculo com as questões relacionadas ao ensino, ou que se sentiram sensibilizados com os objetivos da formação, passaram a serem os principais atores da reforma da Licenciatura. Dentre os protagonistas da reforma, podemos citar a Professora Dra . Maria Regina D. Kawamura, coordenadora do curso na época, a Professora Dr $^{\mathrm{a}}$. Yassuko Hosoume, a Professora Dra . Jesuína L. A. Pacca, o Professor Dr. Alberto Villani, o Professor Dr. Luis Carlos Menezes, o próprio Professor Dr. João Zanetic, entre outros. Originalmente, o número

\footnotetext{
${ }^{7}$ Fonte: Seção de alunos do IFUSP, 2018.
} 
de docentes do IF diretamente envolvido com a nova licenciatura era de 17. Eles são exemplos de docentes que estavam envolvidos de alguma maneira com questões relacionadas ao ensino de Física e a formação de professores, sendo referenciais importantes das discussões e da implementação da nova licenciatura.

O envolvimento dos docentes foi fundamental para garantir o sucesso da implantação das mudanças e, nesse sentido, a presença de um Programa de Pós Graduação Stricto Sensu em Ensino de Ciências teve grande influência. O programa, oferecido pelo Instituto de Física desde 1973, promove - para além do desenvolvimento de pesquisas da área de ensino - o contato e o aprofundamento dos próprios professores do IFUSP em temas atuais do ensino, dessa maneira colabora para a formação continuada dos docentes universitários. Através do Programa Interunidades de Pós-Graduação, vários docentes, que de alguma maneira se relacionam com o ensino básico, com a formação ou aperfeiçoamento de professores, puderam se envolver na produção de projetos e pesquisas de ensino de física. Alguns importantes projetos como o Projeto de Ensino de Física - PEF ou o Grupo de Reelaboração do Ensino de Física - GREF, tiveram seu berço nesse programa de Pós-Graduação. Outros projetos desenvolvidos entre as décadas de 1970 e 1980 acabaram sendo temas de diversas outras pesquisas e ajudaram a nortear outros novos projetos voltados à formação de professores. Por exemplo, entre o final da década de 1980 e início da década de 1990, a USP participava de um projeto financiado pelo Banco Interamericano de Desenvolvimento - BID. Esse programa deu origem ao BID/USP, que reunia professores das áreas de Ciências e da Matemática. No IF, contava com a participação dos professores Alberto Villani, Luiz Carlos de Menezes, Jesuína L. A. Pacca e Yassuko Hosoume, que se dedicavam na formação de professores e na capacitação de professores já atuantes no Ensino Básico. Outro projeto bastante proeminente era a "Construção de Conceitos de Física: Formação de Professores e Pesquisa em Ensino" coordenado pela Professora Dr $^{\mathrm{a}}$. Jesuína L. Pacca que rendeu muitos resultados e novos projetos, durando até 2004.

O contexto no qual os professores do Instituto de Física estavam inseridos poderia fortalecer o ambiente, tornando-o bastante profícua de concepções atuais de ensino, de aprendizagem e de formação. Com investimentos e apoios financeiros de instituições (CAPES, CNPq e FAPESP), os projetos organizados pelos professores do IFUSP puderam tornar-se mais sistemáticos. Isso promoveu a presença de docentes experientes e pesquisas sólidas relacionadas ao ensino e formação, o que ajudou a tornar o projeto da nova licenciatura coerente com as novas concepções de ensino e formação que perscrutam as discussões teóricas e das pesquisas vigentes. Por fim, o Projeto Político Pedagógico de 1993 
traz um Capítulo intitulado "Condições para Implementação" (PPP, 1993). Neste capítulo, o documento preconiza que para garantir o sucesso da implementação da nova Licenciatura em Física é necessária, além da vontade do instituto e diligência dos docentes, a criação de uma comissão de coordenação do curso da Licenciatura com postura efetiva e atuante (PPP, 1993). Essa exigência pressupõe que essa comissão seja responsável pelo acompanhamento e avaliação contínuos. Alguns anos depois essa comissão é criada: a Comissão de Coordenação da Licenciatura (Coc-Licenciatura).

Um segundo momento importante para a formação da identidade curricular do curso de licenciatura acontece em meados dos anos 2000. Com os pareceres do CNE/2002, após um longo processo de discussão, são então instituídas as Diretrizes Curriculares Nacionais para a Formação de Professores da Educação Básica, em nível superior, curso de licenciatura e de graduação plena. Essas diretrizes incorporaram em seus documentos concepções modernas sobre o ensino e sobre a formação. Uma das demandas do documento era a de que os projetos político pedagógicos de cursos de formação inicial deveriam garantir que os conteúdos a serem ensinados no ensino básico fossem tratados de maneira articulada com as suas didáticas específicas. Em outras palavras, as discussões relacionadas ao ensino e a educação, no geral, não devem ser restritas às disciplinas pedagógicas. Os cursos de licenciatura deveriam possibilitar então diferentes espaços de discussão e aprendizado sobre as questões relacionadas ao ensino. Um desses espaços deveria estar associado às próprias disciplinas de conteúdo específico - algo que o Instituto de Física já buscava dez anos antes da elaboração das novas diretrizes.

Além da preocupação com a superação da dicotomia conteúdo-pedagogia, os pareceres da CNE tentam romper com outra dicotomização vigente nos currículos de cursos de licenciatura: as aulas teóricas e as atividades práticas. Até então, eram exigidos pela LDB (e contemplada pela CNE/2001) um mínimo de 300 horas de prática de ensino. Mas dada a importância da superação do paradigma vigente que desvinculava as atividades teóricas das atividades práticas, percebeu-se que aquele mínimo de horas não seria suficiente, passando a serem instituídas 400 horas.

Entendendo que, numa visão mais ampla, a relação entre teoria e prática recobre múltiplas maneiras de acontecer na formação docente, houve a necessidade de se distinguir e definir essas maneiras dela acontecer para poder então ser normatizada nos currículos das licenciaturas. O parecer CNE/CP 9/2001 propõe:

Uma concepção de prática mais como componente curricular implica vê-la como uma dimensão do conhecimento, que tanto está presente nos cursos de formação nos momentos em que se trabalha na reflexão sobre a atividade profissional, como 
durante o estágio nos momentos em que se exercita a atividade profissional. (Parecer CNE/2001, p. 22).

Dessa maneira, distingue-se de um lado a prática como componente curricular e, de outro, o estágio obrigatório supervisionado, definidos em lei.

No currículo implementado pela Licenciatura em Física pela USP em 1993, são exigidas 120 horas de estágio. Originalmente essas horas estavam vinculadas à disciplina de Prática de Ensino, ofertada pela Faculdade de Educação. No entanto, as horas poderiam se estender a outras disciplinas, mas todas sob tutela da FE. Isso significa que, até 2005, apesar do modelo de currículo vigente no Instituto de Física legislar a favor da superação da dicotomia conteúdo e pedagogia, ao mesmo tempo, mantinha a dicotomização entre teoria e prática. Uma vez que a disciplina de Prática de Ensino I e II era oferecida somente nos dois últimos períodos do curso de Licenciatura, o licenciando teria seu primeiro contato com o ambiente profissional escolar tardiamente. Seria então necessária uma renovação do currículo para se adequar aos novos pareceres da CNE de 2001.

Os pareceres da CNE de 2001 trouxeram algumas exigências novas para as Licenciaturas. Nesse âmbito, a USP resolve criar a Comissão Permanente de Licenciaturas, que posteriormente veio a se tornar a Comissão Interunidades das Licenciaturas - CIL. Essa comissão seria responsável pela elaboração de um projeto de licenciatura a partir do qual a instituição poderia proceder à avaliação dos cursos superiores sob sua responsabilidade jurídica. Para essa finalidade, a USP optou por uma via que proporcionasse discussões e revisões sobre os currículos. Uma iniciativa pioneira nesse sentido já havia sido realizada no início dos anos 1990, com o Fórum das Licenciaturas, que influenciaram a construção do currículo da Licenciatura em Física pelo IF em 1992, além de que, cerca de três anos antes do surgimento da comissão, a Faculdade de Educação já havia sugerido mudanças substanciais na estrutura das licenciaturas, sem, contudo, obter uma adesão significativa das outras unidades. Portanto, os documentos que surgiram do Fórum das Licenciaturas daquela época foram lidos e reavaliados pela CIL. Tratavam-se, assim, de uma nova oportunidade de se pensar conjuntamente os novos rumos para a formação de professores do ensino básico e para a integração da universidade com as escolas públicas. Essa concepção da CIL torna evidente o objetivo da proposta da comissão, que é o de tornar mais amplas as discussões sobre a formação. Em decorrência disso, a partir de 2006, a licenciatura ofertada pelo Instituto de Física passa por novas adequações e a grade toma a seguinte forma: 
Quadro 4 - Estrutura Curricular da Licenciatura a partir de 2006 - Diurno (grade obrigatória)

\begin{tabular}{|c|c|c|c|c|c|c|c|c|c|c|}
\hline 苞 & \multicolumn{6}{|c|}{ Física e Ciências afins } & \multirow{2}{*}{$\begin{array}{l}\text { Formação } \\
\text { Pedagógica }\end{array}$} & \multicolumn{3}{|c|}{ Didática da Física } \\
\hline 1 & $\begin{array}{l}\text { Fundamentos } \\
\text { da Mecânica }\end{array}$ & $\begin{array}{l}\text { Introdução } \\
\text { às Medidas }\end{array}$ & $\begin{array}{c}\text { Introdução a } \\
\text { Computa- } \\
\text { ção }\end{array}$ & & $\begin{array}{l}\text { Cálculo I para } \\
\text { Licenciatura }\end{array}$ & $\begin{array}{c}\text { Geometria } \\
\text { Analítica }\end{array}$ & & & & \\
\hline 2 & Mecânica & $\begin{array}{l}\text { Termodi- } \\
\text { nâmica I }\end{array}$ & Gravitação & Ótica & $\begin{array}{c}\text { Cálculo II } \\
\text { para } \\
\text { Licenciatura }\end{array}$ & & $\begin{array}{c}\text { Política e } \\
\text { Organiza- } \\
\text { ção da } \\
\text { Educação } \\
\text { Básica no } \\
\text { Brasil }\end{array}$ & & & \\
\hline 3 & $\begin{array}{l}\text { Eletricidade e } \\
\text { Magnetismo I }\end{array}$ & $\begin{array}{l}\text { Termodi- } \\
\text { nâmica II }\end{array}$ & $\begin{array}{c}\text { Mecânica dos } \\
\text { Corpos } \\
\text { Rígidos e } \\
\text { Fluidos } \\
\end{array}$ & & $\begin{array}{c}\text { Cálculo III } \\
\text { para } \\
\text { Licenciatura }\end{array}$ & & $\begin{array}{l}\text { Psicologia da } \\
\text { Educação } \\
\text { (Bloco) }\end{array}$ & & & \\
\hline 4 & $\begin{array}{l}\text { Eletricidade e } \\
\text { Magnetismo II }\end{array}$ & $\begin{array}{l}\text { Química } \\
\text { Geral }\end{array}$ & $\begin{array}{l}\text { Laboratório } \\
\text { de Mecânica }\end{array}$ & & $\begin{array}{c}\text { Cálculo IV } \\
\text { para } \\
\text { Licenciatura }\end{array}$ & & $\begin{array}{l}\text { Didática } \\
\text { (Bloco) }\end{array}$ & & & \\
\hline 5 & $\begin{array}{l}\text { Oscilações e } \\
\text { Ondas }\end{array}$ & $\begin{array}{l}\text { Relativi- } \\
\text { dade }\end{array}$ & $\begin{array}{l}\text { Eletromag- } \\
\text { netismo }\end{array}$ & & & & & $\begin{array}{l}\text { Elementos } \\
\text { e } \\
\text { Estratégia } \\
\text { para o } \\
\text { Ensino de } \\
\text { Física }\end{array}$ & $\begin{array}{l}\text { Atividade } \\
\text { Acadêmico } \\
\text { Científico- } \\
\text { Cultural }\end{array}$ & $\begin{array}{l}\text { Práticas } \\
\text { em } \\
\text { Ensi- } \\
\text { no de } \\
\text { Física }\end{array}$ \\
\hline 6 & $\begin{array}{c}\text { Física } \\
\text { Moderna I }\end{array}$ & $\begin{array}{l}\text { Laboratório } \\
\text { de } \\
\text { Eletromag- } \\
\text { netismo }\end{array}$ & & & & & & & & \\
\hline 7 & $\begin{array}{c}\text { Física } \\
\text { Moderna II }\end{array}$ & $\begin{array}{c}\text { Laboratório } \\
\text { de Física } \\
\text { Moderna }\end{array}$ & & & & & & $\begin{array}{l}\text { Metodo- } \\
\text { logia do } \\
\text { Ensino de } \\
\text { Física I }\end{array}$ & & \\
\hline 8 & $\begin{array}{l}\text { Comple- } \\
\text { mentos de } \\
\text { Mecânica } \\
\text { Clássica }\end{array}$ & & & & & & & $\begin{array}{l}\text { Metodo- } \\
\text { logia do } \\
\text { Ensino de } \\
\text { Física II }\end{array}$ & & \\
\hline
\end{tabular}

Fonte: Projeto Político Pedagógico da Licenciatura em Física, 2006.

Acima estão descritas as disciplinas que compõem a base comum obrigatória do curso, totalizando 122 créditos-aulas. Nessa nova grade, antecipa-se em um semestre o início da oferta de disciplinas relacionadas à formação pedagógica, passando do $3^{\circ}$ para o $2^{\circ}$ Semestre. Já as disciplinas Psicologia da Educação e Didática tiveram alterações antes de 2005. Nas alterações que ocorreram, elas passaram a ser oferecidas dentro da estrutura de bloco e o aluno passa a poder escolher dentro de um campo de possibilidades e, de acordo a oferta da Faculdade de Educação (Bloco de Didática e Bloco de Psicologia da Educação), aquelas disciplinas que lhe interessassem mais. Já a disciplina de Elementos e Estratégias para o Ensino de Física, que compõe a didática da física - cuja importância já citamos anteriormente -, passa a se tornar obrigatória. Mantém-se ainda a estrutura de blocos, tal como previsto nos 
dois últimos projetos políticos pedagógicos, entretanto com um total de 38 créditos mínimos obrigatórios.

Outra novidade da grade é a disciplina de Práticas em Ensino de Física. É proposto pela CIL que uma parte das 400 horas obrigatórias de estágio curricular supervisionado fosse ofertada pelos próprios institutos, em vez de ser integralmente responsabilidade da Faculdade de Educação. Dessa forma, na Licenciatura em Física é criada a disciplina de Práticas de Ensino de Física. Nela, o aluno executa 100 horas de estágio supervisionado sob responsabilidade do IFUSP. As 300 horas restantes ainda ficam sob a responsabilidade da Faculdade de Educação, a cargo das disciplinas de Metodologia do Ensino. A proposta da criação da disciplina de Práticas em Ensino de Física é o de proporcionar a preparação dos alunos para atuarem na sala de aula, por meio de um tempo de permanência in loco no futuro espaço de exercício profissional com a supervisão de um professor qualificado na área. No IFUSP, a disciplina prevê ainda a problematização do conteúdo próprio da física e análise da prática com referenciais teóricos na perspectiva do ensino e da pesquisa. Assim, os alunos são convidados a se envolverem no planejamento de atividades em sala de aula, elaboração de planos de aula e regência. Os alunos devem ainda apresentar propostas iniciais de planos de aulas e auto avaliação por meio da elaboração de relatórios com caráter reflexivo sobre os próprios planos e regências. Sendo essa disciplina o primeiro contato do licenciando com o ambiente de sala de aula nas escolas, ela promove o olhar profissional do futuro professor. Sua oferta ocorre no terceiro ano do curso de licenciatura ao mesmo tempo em que a disciplina de Elementos e Estratégias para o Ensino de Física. A disciplina conta com uma equipe de monitores-educadores - alunos do Programa de Pós-Graduação Interunidades em Ensino de Ciências - PIEC, cujo objetivo é o de apoio ao processo formativo, a fim de dar conta dos múltiplos modos de ser da atividade acadêmico-científica.

Outras importantes mudanças na estrutura curricular ocorrem em conformidade com o Parecer CNE/CP 2, de 19 de fevereiro de 2002, que define que os projetos pedagógicos dos cursos de licenciatura passem a integrar o chamado Prática como Componente Curricular PCC, cuja suas 400 horas devem ser vivenciadas ao longo do processo formativo. Essa componente é definida como o conjunto de atividades formativas que proporcionam experiências docentes diluídas ao longo do curso entre as disciplinas de caráter propositivo. A PCC visa estabelecer a relação dialética entre teoria e prática, contra, portanto, o modelo aplicacionista, a partir do qual se estuda para depois "aplicar" somente nos estágios finais do curso. Mas a inserção da PCC nos currículos das licenciaturas, conforme mostram as pesquisas no campo educacional, ocorreu de formas enredadas, dificultando a realização dos 
seus objetivos. Mas, tipicamente, as horas vinculadas a essas práticas acabaram ficando subordinadas exclusivamente às disciplinas de educação ou ensino. Para incorporar o PCC na grade de 2006, além das horas de PCC estarem presentes em todas as disciplinas obrigatórias sob responsabilidade da FE, o Instituto de Física optou por alocar as horas de práticas também nas próprias disciplinas da Física, tais como na de Mecânica dos Corpos Rígidos e Fluidos, Física Moderna I e Eletricidade e Magnetismo II, além de Elementos e Estratégias para o Ensino de Física. Essa é uma tentativa de integrar as discussões entre os conteúdos próprios da física e a pedagogia, promovendo o conhecimento e a análise de situações pedagógicas. A proposta é evitar [ou mitigar] a dicotomização entre teoria e prática, sem precisar, no entanto, da observação direta nas escolas. Desse modo, busca-se estabelecer a relação dialética entre a matéria a ser ensinada e a prática, numa tentativa de superar a ideia da sala de aula como o lugar da teoria e o estágio, como o lugar da prática. Então, nas disciplinas, o licenciando vai estudar o conteúdo da Física e, além disso, poderá, por exemplo, desenvolver planos de aula sobre o conteúdo estudado, desenvolver experimentos de baixo custo relacionados ao tema, utilizar tecnologias da informação, propor narrativas orais e escritas de professores, situações simuladas, estudos de caso e produção de material didático.

Além das disciplinas que dariam conta da PCC e do estágio supervisionado, foi pensada também a disciplina de Ciência e Cultura, cujos saberes contemplam as 200 horas propostas pela RESOLUÇÃO CNE/CP 2, DE 19 DE FEVEREIRO DE 2002 para outras formas de atividades acadêmico-científico-culturais. Nessas 200 horas, sob tutela da disciplina de Ciência e Cultura, são realizadas atividades relacionados às artes, literatura, história e outras áreas das humanidades. Fazem parte das horas de atividades científicas, acadêmicas e culturais a proposta e organização de atividades explorando os espaços culturais da cidade, tais como visitas a museus, exposições, apresentações de grupos musicais ou de dança, oficinas, entre outros. Também é possível nesta disciplina convidar algum especialista para debater com os alunos um tema geral, mas de interesse da profissão, como por exemplo, a inclusão da arte, da ciência e da tecnologia na escola, entre outros.

Uma importante proposta que foi reivindicada no documento de 1993 e criada nos anos 2000, como falado brevemente, foi a CoC. - Licenciatura. Essa Comissão se responsabilizou pela avaliação e pela implementação da proposta curricular e de suas adequações. Cabe à Comissão o acompanhamento e a avaliação contínuos das atividades, assim como o encaminhamento das adequações e novos direcionamentos necessários. Essa comissão existe até hoje e vem desempenhando um papel importante de acordo com seus objetivos. 
A grade de 2006 manteve-se até o ano de 2015, quando ocorrem novas mudanças. Porém, em termos de estrutura curricular, há poucas alterações, se comparadas com as alterações curriculares anteriores, conforme se pode perceber pelo Quadro 4, da grade de 2015.

Quadro 5 - Estrutura Curricular da Licenciatura após 2015 - Diurno (grade obrigatória)

\begin{tabular}{|c|c|c|c|c|c|c|c|c|}
\hline 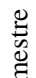 & \multicolumn{4}{|c|}{ Física e Ciências afins } & \multirow{2}{*}{$\begin{array}{l}\text { Formação } \\
\text { Pedagógica }\end{array}$} & \multicolumn{3}{|c|}{ Didática da Física } \\
\hline 1 & $\begin{array}{l}\text { Fundamen- } \\
\text { tos da } \\
\text { Mecânica }\end{array}$ & $\begin{array}{l}\text { Introdução } \\
\text { às Medidas }\end{array}$ & Ótica & $\begin{array}{l}\text { Cálc Fun } 1 \\
\text { Var. Real I }\end{array}$ & & & & \\
\hline 2 & Mecânica & $\begin{array}{l}\text { Física do } \\
\text { Calor }\end{array}$ & Gravitação & $\begin{array}{c}\text { Cálc Fun } 1 \\
\text { Var Real } \\
\text { II }\end{array}$ & $\begin{array}{c}\text { Política e } \\
\text { Organização da } \\
\text { Educação } \\
\text { Básica no Brasil }\end{array}$ & & & \\
\hline 3 & $\begin{array}{c}\text { Eletrici- } \\
\text { dade e } \\
\text { Magnetismo } \\
\text { I }\end{array}$ & $\begin{array}{l}\text { Laboratório } \\
\text { de } \\
\text { Mecânica I }\end{array}$ & $\begin{array}{c}\text { Mecânica } \\
\text { dos Corpos } \\
\text { Rígidos e } \\
\text { Fluidos }\end{array}$ & $\begin{array}{c}\text { Cálc Fun } 2 \\
\text { Var Reais } \\
\text { I }\end{array}$ & & & & \\
\hline 4 & $\begin{array}{l}\text { Eletricida- } \\
\text { de e } \\
\text { Magnetismo } \\
\text { II }\end{array}$ & $\begin{array}{l}\text { Química } \\
\text { Geral }\end{array}$ & $\begin{array}{c}\text { Oscilações } \\
\text { e Ondas }\end{array}$ & $\begin{array}{c}\text { Cálc Fun } 2 \\
\text { Var Reais } \\
\text { II }\end{array}$ & Didática & & & \\
\hline 5 & $\begin{array}{l}\text { Termoesta- } \\
\text { tística }\end{array}$ & $\begin{array}{c}\text { Relativida- } \\
\text { de }\end{array}$ & $\begin{array}{c}\text { Eletromag } \\
\text { netismo }\end{array}$ & $\begin{array}{c}\text { Geometria } \\
\text { Analítica }\end{array}$ & & $\begin{array}{c}\text { Elementos e } \\
\text { Estratégias para o } \\
\text { Ensino de Física }\end{array}$ & & Prática em \\
\hline 6 & $\begin{array}{l}\text { Física } \\
\text { Moderna I }\end{array}$ & $\begin{array}{l}\text { Laboratório } \\
\text { de } \\
\text { Eletromag- } \\
\text { netismo }\end{array}$ & $\begin{array}{l}\text { Comple- } \\
\text { mentos de } \\
\text { Mecânica } \\
\text { Clássica }\end{array}$ & & & $\begin{array}{l}\text { Propostas e } \\
\text { Projetos }\end{array}$ & $\begin{array}{c}\text { Ciência e } \\
\text { Cultura }\end{array}$ & $\begin{array}{l}\text { Ensino de } \\
\text { Física }\end{array}$ \\
\hline 7 & $\begin{array}{c}\text { Física } \\
\text { Moderna II }\end{array}$ & $\begin{array}{c}\text { Laboratório } \\
\text { de Física } \\
\text { Moderna }\end{array}$ & & & LIBRAS & $\begin{array}{l}\text { Metodologia do } \\
\text { Ensino de Física I }\end{array}$ & & \\
\hline 8 & & & & & & $\begin{array}{l}\text { Metodologia do } \\
\text { Ensino de Física II }\end{array}$ & & \\
\hline
\end{tabular}

Fonte: Projeto Político Pedagógico da Licenciatura em Física (2015).

Nas disciplinas do Bloco de Física a mudança ocorre na disciplina de Ótica, que passa a fazer parte das disciplinas obrigatórias já no primeiro semestre do curso de licenciatura. As disciplinas de Termodinâmica I e II são substituídas por Física do Calor e Termodinâmica Estatística. Essas são algumas das alterações que dizem respeito às disciplinas teóricas da Física. Além disso, ocorre uma redistribuição das disciplinas experimentais numa tentativa de torná-las mais integradas às disciplinas teóricas. No bloco das disciplinas da Formação Pedagógica, deixam de ser obrigatórios créditos em disciplinas da Psicologia da Educação (na 
grade de 2006 era exigido um número mínimo de créditos, dos quais o aluno poderia escolher em qual disciplina cursar, conforme a disponibilidade), mas com mudanças na legislação, passa a ser obrigatória a disciplina de Libras. Estão em andamento no momento da implementação desse currículo as discussões acerca de prever, desde o início do curso da Licenciatura o contato do aluno com aspectos da escola e do ensino. A duração da disciplina de Práticas de Ensino de Física passa a ser de 2 semestres. Isso visa distribuir de uma melhor maneira as horas de estágio e as horas de aula. A disciplina de Propostas e Projetos em Ensino de Física torna-se obrigatória e as horas de Atividades Acadêmicas Científicas e Culturais fica sob supervisão da disciplina de Ciência e Cultura.

No que diz respeito à redação do Projeto Político Pedagógico da Licenciatura em Física, o texto toca pontos importantes que subjazem à concepção de formação do Instituto. $\mathrm{O}$ antigo documento de 2005 apresentava uma proposta para o Estágio, para a Prática como Componente Curricular (PCC) e para as Atividades Acadêmicas Científicas e Culturais (AACC), mas não trazia explícitas as maneiras dessas propostas acontecerem dentro da grade. Já o novo documento de 2015 se preocupa em justamente tornar óbvias as maneiras pelas quais essas Dimensões Formativas podem ser contempladas dentro da grade. Isso significa a reiteração do reconhecimento de que essas dimensões têm impacto positivo na formação do professor. A descrição da PCC, por exemplo, é feita de uma maneira que ajuda o aluno a compreender em quais disciplinas essa dimensão formativa deve ocorrer e como ela deve ocorrer.

Quadro 6 - Disciplinas com horas de Práticas como Componente Curricular

\begin{tabular}{|l|c|}
\hline Disciplina & Horas de PCC \\
\hline Mecânica dos Corpos Rígidos e Fluidos & 60 \\
\hline Eletricidade e Magnetismo II & 60 \\
\hline Física Moderna I & 60 \\
\hline POEB & 20 \\
\hline Didática & 20 \\
\hline Elementos e Estratégias Ensino de Física & 60 \\
\hline Propostas e Projetos Ensino de Física & 60 \\
\hline
\end{tabular}

Fonte: Projeto Político Pedagógico Licenciatura em Física (2015). 
No Quadro 5 são apresentadas todas as disciplinas que preconizam essa dimensão formativa. Nas disciplinas do eixo formativo da Física o objetivo da PCC é o de "proporcionar experiências de aplicação de conhecimentos ou de desenvolvimento de procedimentos próprios ao exercício da docência, trabalhando com conteúdos ligados às disciplinas" (PPP, 2015). De acordo com o Projeto Político Pedagógico de 2015, os professores nessas disciplinas podem propor atividades a serem desenvolvidas pelos alunos que visem:

- Elaboração de experimentos para o ensino de determinados conceitos científicos;

- Produção de textos didáticos, paradidáticos e de divulgação científica relacionada ao conteúdo abordado na disciplina.

- Criação de planos de aula envolvendo diferentes recursos como filmes, objetos de aprendizagem, plataformas de ensino, etc.;

- Preparação de exposições dialogadas ou seminários, que podem ser apresentados aos docentes e alunos do curso, encaixando-se no conteúdo da disciplina.

(PPP, 2015)

O Estágio também passa a ter descrito dentro do Projeto Político Pedagógico seus objetivos gerais e os objetivos específicos dentro da disciplina de Práticas de Ensino de Física:

Quadro 7 - Disciplinas que têm horas de estágio

\begin{tabular}{|l|c|}
\hline Disciplina & Horas de Estágio \\
\hline POEB & 20 \\
\hline Didática & 20 \\
\hline Psicologia Da Educação & 100 \\
\hline Práticas em Ensino de Física & 120 \\
\hline Metodologia em Ensino de Física I & 120 \\
\hline Metodologia em Ensino de Física II & Física (2015). \\
\hline
\end{tabular}

Fonte: Projeto Político Pedagógico da Licenciatura em Física (2015).

O Projeto Político Pedagógico de 2015 traz outra novidade: um capítulo destinado aos Espaços Formativos Complementares. Essa é uma discussão inédita e que demonstra que o instituto reconhece que a formação inicial não acontece apenas nos espaços formais da sala de aula na Universidade. Com essa discussão colocada em evidência através do Projeto Político 
Pedagógico, fica documentado que as ações institucionais (da Universidade de São Paulo, do próprio Instituto de Física ou do Governo) são responsáveis por uma parte da formação. Algumas dessas ações são fomentadas por programas como o PIBID, o Programa Ensinar com Pesquisa - USP, o Aprender com Cultura e Extensão e o Programa de Estímulo ao Ensino de Graduação.

O Projeto Político Pedagógico de 2015 também manifesta a atuação da Coc Licenciatura, que passou a desempenhar o papel fundamental de ser a responsável pela coordenação, implementação e avaliação do projeto político-pedagógico do curso. Além disso, a comissão também é responsável por encaminhar propostas de reestruturação do projeto político-pedagógico e da respectiva estrutura curricular (disciplinas, módulos ou eixos temáticos) à Comissão de Graduação do Instituto. Essa foi uma exigência do Projeto Político Pedagógico de 1993, que visava garantir o sucesso das mudanças e que vêm surtindo efeitos positivos na Licenciatura. Resta informar que em 1993, o Instituto de Física contava com cerca de 17 docentes ligados à pesquisa em Ensino de Física que se dispuseram a colocar em prática as mudanças propostas pelo PPP daquele ano. Hoje (2019), o Instituto de Física conta com 7 com tal especialização.

As análises dos documentos oficiais da Licenciatura em Física oferecida pela USP, que no caso consistiram basicamente dos Projetos Políticos Pedagógicos, serviram como nossa principal fonte de dados sobre os indícios do pioneirismo do Instituto em termos de currículo. Fizemos isso por meio da descrição das principais mudanças ocorridas nos Projetos Pedagógicos e currículo. Também foi feita uma busca pelos documentos sobre algumas concepções de formação de professores e objetivos da formação presentes na Licenciatura. Dentre os objetivos presentes dos projetos:

- O Projeto Político Pedagógico de 1993 sugere que a formação da licenciatura em Física deve garantir ao professor o domínio do conteúdo de Física e as habilidades e os conhecimentos específicos da profissão. Isso aconteceria por meio da garantia de que os conteúdos específicos do Ensino estariam presentes em toda a atividade do curso.

- A proposta do Projeto Político Pedagógico de 2005 da Licenciatura em Física foca na formação de um professor de Física para o ensino básico com perfil de educador-pesquisador, de quem se espera: I) tenha consciência da função social do professor de física, compreendendo sua atividade como a de educador, no sentido de integrar seus alunos de maneira consciente à sociedade atual; II) tenha conhecimento sobre a natureza da ciência de tal modo que esse profissional seja capaz de integrar os dois 
conhecimentos, o físico e o pedagógico, em sua prática, e reconhece a necessidade de atualização contínua. Além disso, o Instituto busca formar professores que refletem sobre sua própria prática.

- O Projeto Político Pedagógico de 2015 preconiza que se deva considerar o contexto social da cidade de São Paulo na formação do professor, com isso propõe uma formação de professores que sejam capazes de atuar além da sala de aula. Propõe que a formação esteja ancorada em um conjunto de saberes: Saberes do domínio conceitual; Saberes do Domínio Procedimental e Saberes do Domínio Atitudinal. O curso deve ainda priorizar meios para promover aos licenciandos: o domínio dos conhecimentos científicos e das teorias físicas de forma atualizada; domínio da natureza e forma de abordagem desses conhecimentos; o domínio dos conhecimentos em educação e teorias pedagógicas; o conhecimento das experiências propostas e projetos já desenvolvidos no campo do Ensino de Física.

Todas as mudanças e adequações ocorridas na Licenciatura em Física oferecida pelo Instituto de Física da USP tiveram como foco principal, como se constata na análise documental, proporcionar aos alunos e alunas uma boa formação. Dessa forma, o objetivo deste capítulo foi o de apresentar algumas das principais mudanças ocorridas no currículo da Licenciatura ao longo de quase 30 anos e com isso descrever o processo histórico dessas mudanças. Buscamos alicerçar com isso o argumento do pioneirismo da Licenciatura em Física oferecida pelo IFUSP em termos de currículo.

Assim, os principais indícios do comprometimento e pioneirismo do IFUSP com a formação de professores de Física indicam que a Licenciatura está alinhada à boa formação. Os indícios são: a busca por uma identidade própria para a Licenciatura em Física através da criação de um currículo independente do curso de bacharelado em Física; a garantia da oferta de disciplinas dentro da estrutura de blocos, em um regime que torna a formação inicial mais flexível; a proposta de um currículo mais dinâmico, de acordo com os objetivos atuais de formação; a oferta de disciplinas que discutam aspectos epistemológicos da Física; a presença de um programa de Pós-Graduação que permite, dentre outras coisas, uma "formação continuada" dos próprios professores do Instituto de Física; criação de uma comissão permanente de avaliação e acompanhamento da licenciatura; tornar obrigatória a PCC em disciplinas do instituto e incorporar na grade a disciplina de Ciência e Cultura; trazer para o instituto a responsabilidade de uma parcela das horas de estágio; preconizar a discussão de aspectos profissionais dentro de disciplinas em que culturalmente isso não ocorria. Todas 
essas propostas parecem ter reflexo, ao menos, na alta taxa de formados por ano em relação à média nacional.

Apesar disso, embora as propostas e objetivos presentes no discurso dos projetos pedagógicos da Licenciatura em Física oferecida pela USP sejam promissores em termos de formação, em outros contextos a história parece demonstrar que a prática pode se distanciar das propostas preconizadas em documentos.

Posto isso, constatar como a Licenciatura em Física oferecida pelo IFUSP vem se posicionando de acordo com os objetivos das propostas curriculares e dos Projetos Pedagógicos é outro dos objetivos desta pesquisa. Desta maneira, buscaremos tecer uma compreensão sobre como a Licenciatura vem acontecendo na prática, de acordo com o olhar de profissionais egressos e com isso compreender como depois de tantas adequações e readequações curriculares visando proporcionar uma formação de professores mais consonante às demandas atuais de ensino e de formação, como foram encaminhados ou resolvidos os velhos problemas e dilemas discutidos no Colóquio ocorrido na década de 1980? Quais novos problemas surgiram? Como o currículo é realizado na prática? Como os atores principais desse processo, os professores do Instituto, vêm se posicionando frente a todas essas mudanças? Das informações trazidas pelos nossos sujeitos, pretendemos conseguir compreender alguns desses questionamentos. 


\section{Investigação empírica: O olhar dos egressos}

No capítulo anterior narramos alguns marcos históricos do desenvolvimento do currículo do curso de Licenciatura em Física pela USP. O objetivo foi fazer um levantamento através da análise documental dos projetos político pedagógicos, dos indícios que alicerçam a afirmação de que o IFUSP como lócus de nossa pesquisa, pode ser considerado um caso de sucesso em relação à formação, com indícios adicionais aos resultados, em termos de número de formandos, bastante superior ao de outras instituições do país. De fato, os documentos apresentam concepções contemporâneas de formação de professores de física e de ensino. Entretanto, o que é posto nos documentos oficiais não é suficiente para compreender como acontece o processo formativo na prática. Uma maneira para compreender como é o processo formativo do IFUSP é através do olhar de seus egressos, a maior parte profissional, formada pela instituição citada, revelado através das entrevistas. As falas desses sujeitos indicam os elementos que foram centrais e marcantes na formação e quais sentidos esses elementos possuem para os entrevistados. Essas informações vão dar subsídios para uma descrição de como ocorre o processo formativo na prática. Isso pode possibilitar verificar como a Licenciatura em questão vem se posicionando de acordo com a proposta curricular. Então, a proposta deste capítulo é a de tornar evidente os fundamentos das escolhas metodológicas de produção de dados desta pesquisa e descrever como foi esse processo até obtermos as informações esperadas, de maneira que seja possível tornar compreensível o processo de busca por informantes, o processo de entrevistas e o de análise das entrevistas. Dessa maneira,iniciaremos apresentando uma breve descrição de alguns elementos considerados importantes do contexto dos nossos sujeitos que estão relacionados com a motivação pela escolha da Licenciatura em Física oferecida pelo IFUSP, o currículo que o sujeito vivenciou e os aspectos gerais da primeira experiência como professores de física. Tais elementos auxiliaram na compreensão do sentido atribuído pelos sujeitos ao processo formativo proporcionado pelo IFUSP. As informações contidas nas descrições consistem de excertos extraídos das entrevistas e o objetivo não é o de fornecer ao leitor uma interpretação, apenas dados. Vale frisar que essa descrição é feita segundo a perspectiva do próprio entrevistado, tal como nos foi contado. 


\section{Herschel}

A entrevistada Herschel é a informante que vivenciou a Licenciatura em Física durante o período anterior à reforma do currículo e, por ter se formado em 1985, ela experimentou o curso ainda no molde $3+1$. Como muitos alunos que ingressam na Licenciatura em Física, seu objetivo inicial era o de se formar como Bacharel em Física. Mas, também pelos mesmos motivos sofridos por muitos alunos que deixam a Física, ela conta que o curso "não dava" o que ela "esperava". Em um tom romântico ela conta que quando era pequena, olhava o céu e sentia uma sensação muito boa. Herschel tinha em mente que, se ela pudesse compreender mais sobre o Universo, ela teria sempre aquela sensação experimentada quando criança. Assim, ela ingressou na Física, com a expectativa de se tornar astrônoma. Ela entendia que esse curso poderia dar conta de responder suas indagações e intensificar seu elo com a natureza e a sensação boa que sentia quando criança. Entretanto, com a vivência no curso ela percebeu que ele não estava dando conta dessa expectativa. Então, no seu terceiro ano como aluna do Bacharelado em Física, ela decidiu pedir transferência para a Licenciatura em Física. Antes dessa decisão, ela teve uma experiência interessante, uma aula na Faculdade de Educação que foi decisiva para a mudança de curso. Ela nos conta que fez uma disciplina e o professor, na época, era muito apaixonado pelo ensino. Isso a contagiou de tal maneira que fez com que ela se tornasse também "apaixonada pela educação". Assim, a Licenciatura em Física passou a ser a "sua opção número um”, como ela comenta. O início da sua carreira, em contrapartida, não teve um desfecho apaixonado. Foi numa escola que ela relembra não ter muitos problemas. Como Herschel estava muito motivada com as aulas que ela havia tido na Licenciatura, e principalmente com o GREF - recém "saído do forno", a entrevistada tenta "aplicar" a proposta do material com seus alunos. No entanto, ela fica desapontada, pois percebeu que a realidade na sala de aula na escola era diferente daquela prescrita na sala de aula na faculdade e o que ela acaba fazendo com seus alunos é o contrário do que propõe o GREF. Outro problema dessa escola era em relação ao ambiente de trabalho, que ela achava “depressivo". Havia pouca colaboração entre os professores, pouco contato e pouca troca entre os pares. Como consequência, certo tempo depois, ela acaba desistindo de lecionar e presta vestibular para outro curso em uma cidade do interior. Só depois de alguns anos é que Herschel retoma o contato com a escola. Na nova escola onde passa a trabalhar, ela se sente renovada, pois conta com uma equipe de professores e coordenação muito engajada com a educação e com uma proposta de ensino que Herschel considera "muito boa". A entrevistada 
começa se sentir animada novamente com o ensino e dessa vez investe no papel de professora, permanecendo até hoje na profissão.

\section{Heisenberg}

O entrevistado Heisenberg formou-se em 1995, período de transição entre o currículo da Licenciatura atrelado ao do bacharel em Física, na perspectiva 3+1, e o novo currículo proposto para Licenciatura em Física do IFUSP. Assim como a Herschel, Heisenberg veio de escola pública. Ele conta que por esse motivo enfrentou dificuldades em algumas disciplinas, tanto que sua primeira reprovação foi durante a graduação. Apesar dessa dificuldade, o seu olhar para o processo vivenciado na graduação é positivo. Sua fala revela que o ingresso em um curso no Instituto de Física possibilitou que ele conhecesse pessoas que tinham muito em comum com ele e das quais até hoje fazem parte do seu círculo de amizade. Um desfecho feliz de uma situação preocupante vivenciada por muitos estudantes do ensino básico ou do ensino superior: Heisenberg nos revela que era vítima de bullying na escola e ao ingressar em um curso de Física ele descobriu que outros alunos no Instituto também foram alvo desse tipo de agressão. Dessa união entre pares surge um grupo que enfrenta unido as dificuldades impostas pelo processo formativo. Uma delas é em relação ao dilema que a maioria dos alunos de Física sofre: conseguir ser aprovado nas disciplinas. Com esse intuito, Heisenberg e seus colegas se reúnem para estudar - prática que ele carrega consegue até hoje em relação às disciplinas que ele faz na Pós-Graduação. Outro aspecto em comum entre a entrevistada Herschel e o entrevistado Heisenberg é que os dois desejavam tornarem-se astrônomos. Mas a realidade do curso de Física impõe muitas vezes outros caminhos. Em 1992, antes de decidir mudar de curso, Heisenberg fez parte de um programa que concedia bolsa auxílio para alunos carentes. Os alunos que participavam desse programa exerciam 10 horas de monitoria em projetos da USP. O projeto que o entrevistado participou funcionava como uma exposição de experimentos de física. Como monitor nesse projeto, entre trabalhar com a manutenção e construção dos aparatos experimentais e apresentação, Heisenberg descobriu uma nova motivação. Isso significa que diante das dificuldades impostas pelo curso, ele descobre outros caminhos profissionais e passa a vislumbrar a possibilidade de ser professor. Sua primeira experiência como professor ocorre enquanto ainda estava cursando a Licenciatura. Mas ele revela que era um professor "tradicional, conteudista" e "sem didática", características que ele mesmo se atribui. Lamenta que, apesar de conhecer muitos experimentos de Física, ele não fazia nenhum em sala de aula e revela que, ao buscar saídas para dificuldades enfrentadas por 
ele na sala de aula na figura de professor, se espelhava em professores que teve no ensino médio e cursinho.

\section{Maxwell}

Maxwell ingressou na Licenciatura em Física pelo IFUSP em 1998 e formou-se em 2002. Isso significa que esse sujeito vivenciou plenamente o currículo da nova Licenciatura em Física do IFUSP. Entretanto, ele já havia feito uma boa parte da graduação em outro curso correlato à Física também pela USP e, antes de decidir ingressar na Licenciatura em Física, ele já lecionava. O descontentamento com o primeiro curso, a paixão pela Ciência e a experiência como professor em uma escola ajudaram Maxwell na decisão de ingressar na Licenciatura. Nosso entrevistado conta que a equipe pedagógica da escola era bastante fortalecida e engajada com o ensino e seguia uma linha socioconstrutivista.

Esse fator foi muito impactante na formação profissional desse sujeito. Enquanto muitos entrevistados descobrem o significado e importância de alguns aspectos da rotina da profissão de professor tardiamente, Maxwell ingressa na Licenciatura compreendendo a relevância desses aspectos da profissão. E isso foi algo que aquela experiência anterior à Licenciatura em Física embutiu nele. Por consequência, Maxwell atribui muito valor às disciplinas que tratam desses assuntos. Como Maxwell revela, antes dessa experiência, ele achava que qualquer pessoa poderia ser professor, bastava estar disposto e para isso não havia necessidade de uma formação ou preparação anterior. Mas depois da escola, ele passa a enxergar a importância que uma Licenciatura tem. E o que ele espera da Licenciatura é aprender a preparar um bom plano de aula e saber executá-lo, aprender a fazer uma avaliação adequada e que condiz com os objetivos da aprendizagem e aprender novas maneiras de ensinar.

\section{Feynman}

Diferentemente dos três sujeitos apresentados até agora, Feynman ingressou direto na Licenciatura em Física sem antes passar por outra graduação. Assim como Maxwell, Feynman também vivenciou plenamente o currículo da nova Licenciatura oferecida pelo IFUSP. Em 2003, poucos meses antes de se formar, esse entrevistado conta sua primeira experiência na escola. Na sua primeira semana de aula, cheio de empolgação depois das aulas na Licenciatura, resolveu fazer um jogo com os alunos. Mas revela que foi uma decepção, houve briga entre os alunos, ele não soube o que fazer e isso o desapontou muito. Nosso 
entrevistado também revela que demorou a se adequar a sala de aula, principalmente em relação ao conteúdo. De acordo com Feynman, o conteúdo visto no curso de Licenciatura em Física é diferente daquele de sala de aula. A maneira que ele encontrou para superar essa dificuldade foi através do foco no conteúdo do livro didático e nos exercícios que o livro adotado na escola propunha. Feynman também conta um pouco das dificuldades que sofreu durante a graduação, por residir em outra cidade. Ele nos fala do quanto se esforçava para chegar até a USP para assistir às aulas e de um episódio em que, depois de um temporal que alagou muitas regiões de São Paulo, foi muito difícil sua chegada ao campus. Além de ter chegado molhado, Feynman enfrentou muitas adversidades no caminho, tudo para assistir às aulas. Entretanto, ele conta como isso o decepcionou:

\footnotetext{
Cheguei à USP molhado e teve uma aula horrível e na sequência foi outra aula horrível e eu pensei que não iria mais assistir essas aulas. Então, não assisti mais a essas aulas e só fui fazer a prova. Porque, com alguns professores, você assistindo ou não a aula, é basicamente a mesma coisa. (Feynman)
}

\section{Fermi}

Fermi era aluno do curso de Bacharelado em Física e, enquanto se formava, lecionava como professor nessa mesma área em uma escola do Estado de São Paulo, na periferia. Hoje, ele mora no interior do Estado de São Paulo, onde continua lecionando para a rede pública de ensino como professor de física. Com uma diferença de 10 anos em relação ao Feynman, Fermi formou-se em 2013. Isso pressupõe que esse entrevistado tenha vivenciado o currículo da Licenciatura em Física do IFUSP implementado em 2006. Ele conta que, como já estava lecionando, "uma coisa levou a outra" e, mesmo depois de obtido o diploma de Bacharel, ele queria o diploma da Licenciatura. Isso funcionaria, conforme ele mesmo revela, como "ter uma carta na manga". Mesmo antes de ingressar na Licenciatura em Física, Fermi compreendia que os conhecimentos de um Físico não eram suficientes para ser professor. Ele concorda que entender como um aluno pensa ou o que seja uma boa aula são requisitos que só a Licenciatura daria conta de munir o professor. À parte dessa concepção, ele conta que a primeira avaliação que fez dos seus alunos foi bem ruim. Problemas semelhantes aconteceram em outros aspectos da prática, no dia a dia da sala aula, mas que com o tempo ele foi encontrando modos de ajustar. Mas revela que, muitas coisas que aprendeu sobre o ensino, ele não consegue levar para sua rotina de aula. Para ele, as discussões nas aulas da graduação sobre o ensino e a educação são distantes da realidade do ambiente escolar da rede pública, são idealizadas. 


\section{Planck}

Em 2009, Planck ingressou no curso de Bacharelado em Física pelo IFUSP, mas cerca de 2 anos depois, migrou para a Licenciatura. Essa opção foi uma alternativa de carreira, já que ele gostava de física, mas se sentia descontente com o rumo que o curso de graduação em Física assumiu, principalmente em relação às aulas. Tendo se formado em 2014, um ano depois de Fermi, Planck também teve contato com as mudanças implementadas na última reestruturação do currículo da Licenciatura em Física. Planck revela que o fato das aulas no Bacharelado focarem, segundo ele, na resolução mecânica de exercícios e os professores não valorizarem as dúvidas dos alunos, colocou a escolha pela Física em xeque. Com esse sentimento, ele começa a fazer algumas disciplinas de educação na Licenciatura em Física. Agora ele começa experimentar uma nova sensação que o agrada mais. Isso porque, conforme ele revela que as discussões travadas nas aulas, a abordagem dos professores e a maneira como a física é discutida o afetavam de uma maneira mais positiva. Ele sentia que estava aprendendo algo que mexia com ele. Com isso, Planck resolve pedir transferência para a Licenciatura em Física. Enquanto dava andamento ao projeto de se formar na Licenciatura em Física, Planck tornou-se monitor de cursinho. Em seguida, concomitantemente ao término do curso de Licenciatura, o entrevistado começou a dar aulas em uma escola particular. Essa escola era dirigida por uma equipe que preconizava uma visão de ensino que fugia da tradicional, com uma abordagem humanista. Então, a prática em sala de aula e a metodologia usada por Planck, não tinham como ser tradicionais. Planck salienta que vários aspectos do dia a dia da profissão ele aprendeu na própria escola.

\section{Gauss}

Gauss havia começado na semana concomitante à entrevista, a trabalhar em uma escola particular. Ainda um pouco sem saber como planejar a sua aula, ele revelou que se pautaria nas anotações em seu caderno. A ideia que ele tinha era a de que durante a aula ele falaria dos conceitos e faria exercícios. Gauss havia se formado há poucos meses, no final de 2016. A licenciatura em Física foi sempre sua primeira opção. Ele também passou por um momento de crise no curso. Isso é curioso, pois esse sentimento também foi vivenciado por Planck, Maxwell, Heisenberg e Herschel. Apesar do contexto da crise sofrida por Gauss ser um pouco diferente daquelas descritas pelos outros entrevistados, talvez a origem seja a 
mesma. Essa crise que Gauss descreve nasce, segundo ele, do sentimento de frustração. Os alunos, quando ingressam no curso, possuem expectativas em relação às aulas e aos professores, mas parece que, para esses entrevistados, eles acabam experimentando graus de desapontamento com ambos. Com Gauss não foi diferente. E assim como Heisenberg, Gauss também revelou como superou as dificuldades. Ele conta que se manteve - assim como outros alunos se mantêm - firme no objetivo de se formar através do apoio das relações que se estabelecem entre os alunos da Licenciatura em Física.

\section{Mayer}

Mayer é a nossa entrevistada que não havia se formado até o momento do depoimento. Ingressou no curso de Bacharelado em Física em 2014 e, em 2017, transferiu-se para a Licenciatura em Física. Ela conta que já pensava em ser professora desde antes do vestibular, mas sentia um pouco de pressão da família para escolher outra opção. Mayer revela que entendia que, para ser professora, o curso de bacharelado deveria ser feito antes da Licenciatura, pois, para ela, se deveria cursar primeiro as disciplinas da Física e só depois as disciplinas relacionadas à profissão - uma concepção ancorada no modelo tradicional de formação. Porém, Mayer revela que essa sua concepção mudou com o passar dos anos. Isso foi possível através dos conhecimentos proporcionados pela convivência com outros alunos veteranos da Licenciatura em Física. Esses alunos comentavam sobre como era a Licenciatura, discutiam aspectos do ser professor, falavam das disciplinas, as possibilidades de atuação profissional, etc. Além disso, os conhecimentos e trocas de ideias proporcionadas pela Semana da Licenciatura (evento promovido pelo Instituto de Física) colaboraram para a mudança da visão de Mayer sobre a Licenciatura e o ser professor. Aliado às suas próprias mudanças de concepção sobre o ensino e sobre a formação, Mayer revelou que se aborrecia muito com o curso de Bacharelado em Física. Os problemas giravam em torno, a seu ver, das práticas desastrosas de alguns professores. Como solução, ela busca a transferência para a Licenciatura em Física. Mayer vivencia o currículo proposto pelo Projeto Pedagógico de 2015.

\subsection{A organização dos dados - uma busca por dimensões de análise}

O objetivo central da análise das entrevistas é o de inferir, a partir dos textos gerados das transcrições, as dimensões que ajudarão a guiar a análise dados. Na pesquisa qualitativa, 
os dados são as informações que o pesquisador necessita para compor uma descrição e uma compreensão de algum fenômeno. Nesta pesquisa, o fenômeno estudado foi o da formação inicial, tendo como lócus a Licenciatura em Física do IFUSP. Os dados brutos são constituídos pelas opiniões, visões e experiências vividas na formação inicial, pelos elementos que foram centrais e marcantes nessa formação e pelos sentidos que alguns dos professores entrevistados, formados pelo IFUSP, deram a esse processo. Dos dados inferidos das entrevistas é possível estabelecer uma descrição do processo formativo da Licenciatura estudada. Tal descrição, por sua vez, pode fornecer subsídios que viabilizem a construção de uma compreensão do fenômeno estudado. Uma vez compreendido o fenômeno, a expectativa é a de que isso proporcione algumas reflexões e nos forneça alguns parâmetros positivos de formação.

Algo que esperamos constatar, através do olhar dos nossos sujeitos, é como essa formação ocorre na prática, apesar dos Projetos Pedagógicos proporem uma formação de professores de qualidade e consonante às demandas atuais de ensino e de formação. Quais os problemas e dilemas dessa formação? Porém, conceber uma análise de dados qualitativos de maneira objetiva, transparente e reprodutível não é uma tarefa simples. $\mathrm{Na}$ pesquisa qualitativa são possíveis diversos vieses interpretativos das falas e isso pode tornar o processo obscuro. Isso significa que, a todo o momento, o pesquisador deve estar atento para não incorporar interpretações pessoais, impressões falsas, inferências espontâneas ou literais na análise textual. Portanto, o pesquisador deve adotar a atitude de vigilância crítica diante do texto, buscando o significado das inferências em teorias fortes o bastante para que seja possível uma interpretação coerente desses dados. Em outras palavras, o elemento dedutivo deve ser justificado por meio das considerações teóricas (MAYRING, 2002, p. 116). Dessa maneira, buscaremos desenvolver a metodologia que forneceu os subsídios para a construção das dimensões de categorias que se originaram dos dados analisados. O objetivo é o de tornar esse procedimento.

\subsubsection{A Metodologia de Análise do Conteúdo}

Um percurso metodológico de construção de dimensões de análise que se enquadrou bem na proposta da presente pesquisa foi a Análise de Conteúdo. Bardin (2007) define essa metodologia de produção de dados como: 
(...) um conjunto de técnicas de análise das comunicações visando obter, por procedimentos sistemáticos e objetivos de descrição do conteúdo das mensagens, indicadores (quantitativos ou não) que permitam a inferência de conhecimentos relativos às condições de produção/recepção (variáveis inferidas) destas mensagens. (BARDIN, 2007, p.42)

Essa é uma abordagem historicamente construída que objetiva fornecer subsídios teórico-metodológicos para processos em que se acentuam a "inferência" (MINAYO, 2001, p. 301). Bardin (2007) e Franco (2008) propuseram três grandes etapas relativas ao desenvolvimento de uma pesquisa qualitativa ancorada na Análise do Conteúdo. Essas autoras buscaram sistematizar a metodologia, tornando evidentes os objetivos de cada fase e o procedimento mais adequado para alcançar os objetivos. Essa sistematização pode ser resumida de acordo com Quadro 7:

Quadro 8 - Fases do desenvolvimento da pesquisa qualitativa segundo Bardin (2007) e Franco (2008)

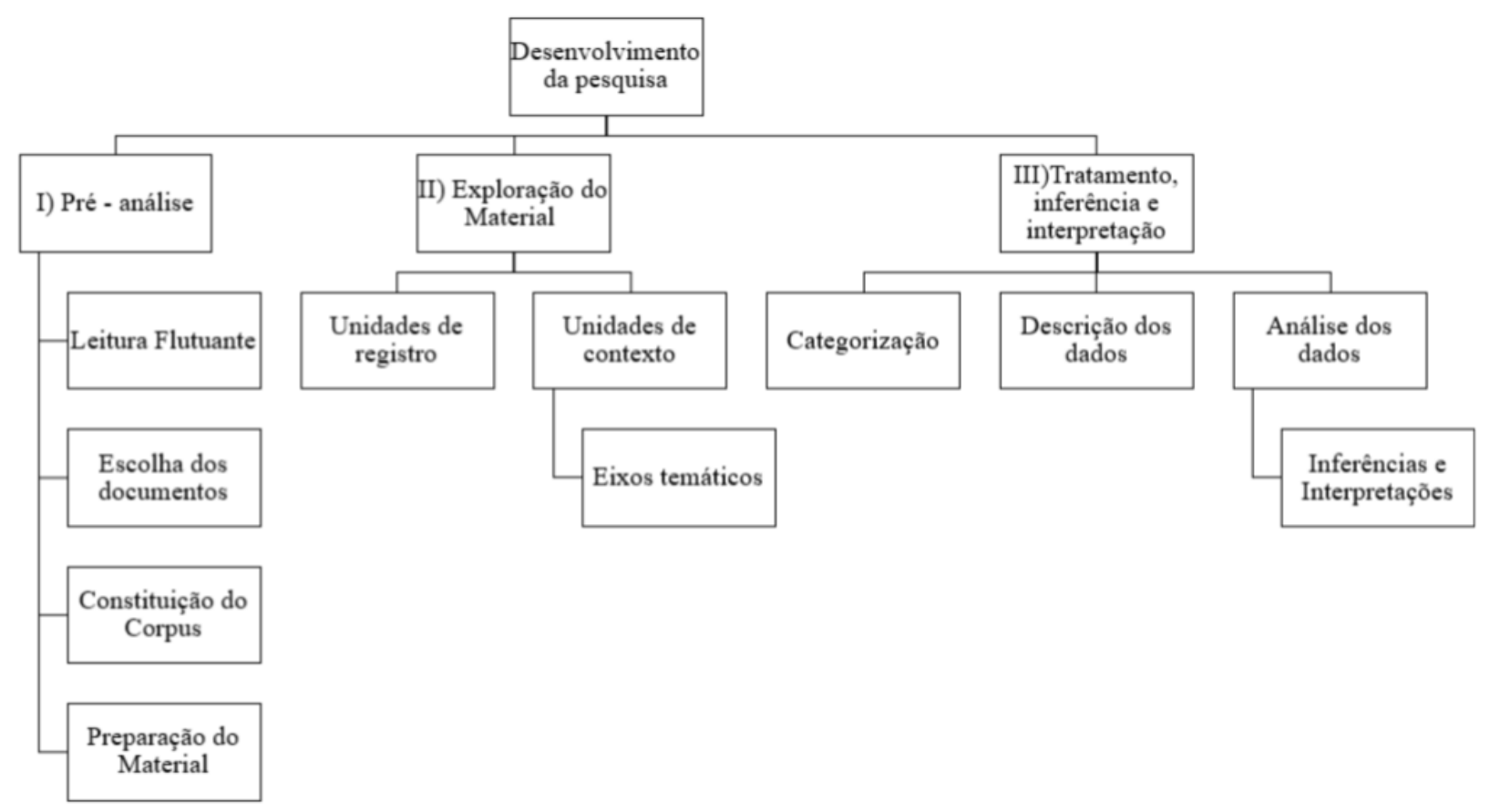

Fonte: Bardin (2007) e Franco (2008).

As etapas propostas por Bardin (2007) e Franco (2008) para o desenvolvimento de uma pesquisa qualitativa, no qual buscamos utilizar como fonte balizadora para a produção de dados do presente estudo são:

I) Pré-análise: Nessa fase, o documento foi organizado de maneira que fosse possível a constituição do corpus, que Bardin (2007) define como "o conjunto dos documentos obtidos em conta para serem submetidos aos procedimentos analíticos" (BARDIN, 
2007, p. 96). Nesta pesquisa, o corpus é constituído pelas transcrições das entrevistas. Logo em seguida às transcrições, foi realizada a leitura flutuante. Esse foi o primeiro contato com os dados, cujo objetivo foi ter as primeiras percepções das mensagens expressas. Essa fase auxilia na fase seguinte, de exploração do material, pois a leitura flutuante, fluida e corrida possibilita que os aspectos relevantes das entrevistas se desprendem naturalmente do texto. Já despontaram nessa fase alguns elementos mais marcantes na formação dos sujeitos entrevistados e algumas visões sobre a licenciatura, além da constatação de algumas similaridades e distinções entre as trajetórias dos sujeitos. Nessa fase há a necessidade de preocupação com as inferências espontâneas.

II) Exploração do Material: fase de aprofundamento assentado na atitude de vigilância crítica e sistematização das informações visando a elaboração das unidades de registro. As unidades de registro são as menores partes do conteúdo. A ocorrência é registrada de acordo com categorias, que podem ser de tipos distintos: palavra, tema, personagem, item (FRANCO, 2008). As unidades de registro escolhidas neste trabalho foram os temas, que são afirmações sobre determinado assunto que envolve "não apenas componentes racionais, mas também ideológicos afetivos e emocionais" (FRANCO, 2008, p. 43). Cada frase ou oração que remetia a algum tema foram extraídas do texto e copiadas para um documento à parte, formando a unidade de registro. Da unidade de registro, pudemos agrupar as frases e orações em temas recorrentes e deduzir as categorias, com a consciência de que cada tema deve se relacionar com algum arcabouço teórico. Vale frisar que essa identificação inicial dos temas pode ser derrubada ou substituída por outra, de acordo com o avanço dos estudos teóricos e isso ocorreu em alguns momentos durante o desenvolvimento dessa etapa. A exploração do material foi à fase que exigiu mais da pesquisadora. Etapa de morosidade, muitas idas e vindas entre as categorias e teorias, que levou cerca de um ano, atéque tenha sido "maturada".

III) Tratamento, inferência e interpretação: Esse é o momento de busca pela compreensão de um fenômeno. No caso desta pesquisa, o fenômeno é compreender como ocorre a Licenciatura em Física da USP na prática, de acordo com os sujeitos de pesquisa. Para isso, seria necessário que a pesquisadora pudesse construir uma descrição dos dados, a fim de compreender o fenômeno observado. Se os dados emergem de um texto - as entrevistas - a descrição deve ser feita baseada nas categorias de análise do texto. Para o propósito deste trabalho, a descrição foi feita 
com base em categorias de temas inferidas do conteúdo declarado explícito e implícito no texto. Estes conteúdos deram origem a dimensões de análise, que na proposta deste trabalho, são constituídos pelos elementos marcantes da formação, os sentidos que os entrevistados deram as práticas formativas, as práticas mais valorizadas, os conhecimentos, atitudes e valores que os egressos entrevistados salientaram como fundamentais nas práticas, além das opiniões sobre essa formação. Partindo da descrição é possível construir uma compreensão e uma interpretação do fenômeno alicerçada às teorias.

Para situar o leitor mais ou menos onde cada etapa se enquadra na organização desta dissertação, apresentamos o seguinte esquema: a etapa I) Pré-análise condiz com as descrições e informações desenvolvidas neste capítulo; a etapa II) Exploração do Material e da Categorização será descrita na sequência em Organização dos dados para análise: criação das dimensões; O Capítulo 7 contempla a etapa III) Tratamento, inferência $e$ interpretação.

\subsubsection{Organização dos dados para análise: criação das dimensões}

De modo geral, nesta fase de exploração do material são feitas as sistematizações e as decisões que possibilitem alcançar os objetivos formulados para a pesquisa. Essa exploração exige a codificação do material e categorização dos dados, processo pelo qual os dados brutos são sistematicamente transformados em unidades que descrevem de forma exata as características pertinentes ao corpus analisado. Três elementos são utilizados nesse método de sistematização da análise temática dos dados: unidades de registro, unidades de significação (sentido) e unidades de contexto. As unidades de registro indicam as regras de sentido do recorte escolhido: palavras, frases, segmentos do texto. Para o objetivo deste trabalho, as unidades de registro consistem em segmentos do texto - excertos das falas ou recortes das falas. As unidades de sentido (ou significação) são as ideias que foram destacadas pelo pesquisador e que propõem as significações obtidas do texto analisado, no caso desta pesquisa, são os temas. As unidades de contexto são segmentos ampliados que permitem compreender os recortes das unidades de registro (BARDIN, 2007), sendo que para o nosso propósito, essas unidades são constituídas pelas dimensões de análise.

O objetivo deste estudo é compreender como é o processo formativo oferecido pelo IFUSP na prática. Esse dado deve ser obtido sob o prisma das visões, opiniões e elementos 
marcantes trazidas pelos sujeitos através das entrevistas. Então, para alcançar esse objetivo, as falas (unidades de registro) de cada entrevistado que faziam menção a temas em comuns (unidades de significação) entre os entrevistados, foram agrupadas. Esses agrupamentos das falas em torno de temas comuns deram origem às dimensões de análise (unidades de contexto), a saber: I) A escolha pela Licenciatura; II) Apreciação geral dos sujeitos sobre a Licenciatura; III) Início da atuação como professor de Física em escola; IV) Disciplinas: Visões, opiniões, experiências e elementos marcantes. Essas dimensões serviram para fins de uma organização primeira dos dados, de modo a possibilitar a construção de uma análise descritiva das informações trazidas pelos sujeitos na entrevista. As dimensões de análise representam o olhar do pesquisador focado nos temas que foram abordados mais enfaticamente pelos entrevistados. Essas dimensões estão apresentadas no Quadro 8 abaixo:

Quadro 9 - Dimensões de análise que se desprenderam das entrevistas

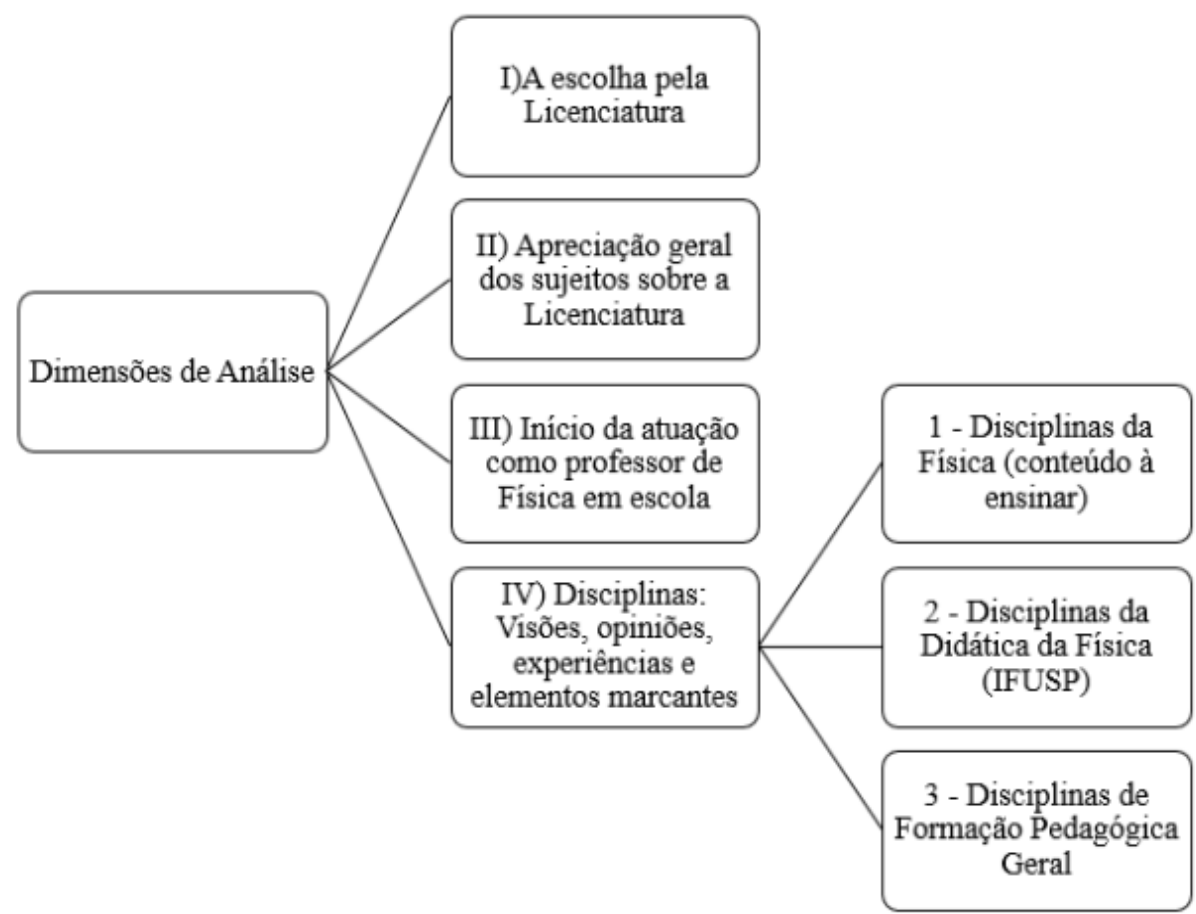

Na dimensão I) A escolha pela Licenciatura, as falas expressam quais foram os principais motivos que levaram os sujeitos a escolherem essa graduação. Na dimensão II) Apreciação geral dos sujeitos sobre a Licenciatura, os sujeitos revelam suas concepções e visões sobre o que a Licenciatura proporcionou em termos da profissão e que sentido teve a Licenciatura. Na dimensão III) Início da atuação como professor de Física em escola, o teor das falas giram em torno dos principais conflitos vividos pelos entrevistados no início da carreira. Finalmente, na dimensão de análise IV) Disciplinas: visões, opiniões, experiências e 
elementos marcantes, conseguimos agrupar as falas de acordo com os dados fornecidos pelos entrevistados a respeito das disciplinas da Física (conteúdo a ensinar), das disciplinas Didática da Física e das disciplinas da Formação Pedagógica Geral. Essas sub-dimensões de análise proporcionaram conhecer, sob o olhar dos sujeitos, quais foram os elementos marcantes das disciplinas e as práticas mais valorizadas (ou não) pelos entrevistados. A seguir, apresentamos um quadro com todas as falas separadas por dimensões de análise e quando possível, indicamos o tema ao qual a fala se refere. Além disso, as falas estão ordenadas cronologicamente, do sujeito que se formou a mais tempo ao sujeito que se formou a menos tempo. Quando possível, também indicamos a qual categoria de análise teórica o sentido da fala se enquadra. Para o leitor, avisamos que pode ser que a leitura pormenorizada desse quadro pode ser desnecessária, visto que faremos a descrição pormenorizada das dimensões no próximo capítulo. Dessa forma, se o leitor preferir, pode seguir para o próximo capítulo e, se sentir necessidade, retornar às falas, sem ocorrer perda o sentido.

\section{I) A escolha pela Licenciatura}

Quadro 10 - Falas sobre a escolha pela a Licenciatura

\begin{tabular}{|l|l|l|}
\hline Sujeito & $\begin{array}{l}\text { Tema: } \\
\text { motivo da } \\
\text { escolha }\end{array}$ & Unidade de sentido \\
\hline Herschel & $\begin{array}{l}\text { Crise com o } \\
\text { Bacharelado }\end{array}$ & $\begin{array}{l}\text { Me formei em 85. Comecei com o Bacharelado. Eu queria fazer astronomia (...) } \\
\text { gostava da natureza [compreender a natureza]. Descobri que Física estudava a } \\
\text { natureza, então eu resolvi fazer Física. Mas quando eu entrei foi uma decepção, } \\
\text { pois o curso não fornecia o que eu esperava. Eu comecei a olhar o céu quando } \\
\text { eu era pequena, e eu tinha uma sensação muito boa, então eu achava que se eu } \\
\text { conhecesse mais sobre o universo, continuaria a ter aquela sensação, mas o } \\
\text { curso não era nada disso. Fiquei em crise muito tempo, mas não conseguia } \\
\text { deixar à Física. Fiz um curso de introdução à astronomia, tinha algo que eu } \\
\text { buscava e não encontrava no curso. Uma satisfação. Então em um curso da } \\
\text { Licenciatura, na Faculdade de Educação, o professor foi muito importante. Ele } \\
\text { era muito apaixonado pelo ensino e pela educação. Foi no curso de Estrutura e } \\
\text { Funcionamento da Educação, e essa disciplina com esse professor me deu uma } \\
\text { visão da educação que eu nunca tinha pensado, foi daí que eu fiquei apaixonada } \\
\text { pela educação. }\end{array}$ \\
\hline Heisenberg & $\begin{array}{l}\text { Crise como o } \\
\text { Bacharelado }\end{array}$ & $\begin{array}{l}\text { Diferente dos meus colegas eu vim de uma escola pública. Então apesar de ter } \\
\text { feito o curso técnico, eu tinha muita dificuldade em matemática. Então foi bom } \\
\text { porque aqui na USP temos uma série de benefícios, como assistência médica } \\
\text { bandejão, etc. Por outro lado, para passar nessas disciplinas eu levei bastante } \\
\text { tempo. Aqui foi a primeira vez que repeti na minha vida. (..) Para ser sincero } \\
\text { eu não queria dar aula. Quando entrei eu queria ser astrônomo, na época para } \\
\text { ser astrônomo você fazia Geofísica, Geologia ou Física. Só que eu estava tendo } \\
\text { dificuldade para seguir o plano, e era por causa da matemática. Fui sendo } \\
\text { realista e me perguntando qual curso que eu poderia fazer, já que tinha } \\
\text { dificuldade em algumas disciplinas. Em 1992 trabalhei em uma exposição de } \\
\text { Física como monitor e percebi ali que sabia algo. E as pessoas gostavam da }\end{array}$ \\
\hline
\end{tabular}




\begin{tabular}{|c|c|c|}
\hline & & $\begin{array}{l}\text { minha explicação. Então se tinha dificuldade em algumas matérias, mas ainda } \\
\text { gostava de Física e gostava de ensinar, por que não? Aos poucos fui me } \\
\text { conscientizando dos meus atributos, e descobrindo outros. }\end{array}$ \\
\hline Maxwell & $\begin{array}{l}\text { Contato com } \\
\text { a sala de } \\
\text { aula/ensino e } \\
\text { crise com o } \\
\text { Bacharelado }\end{array}$ & $\begin{array}{l}\text { Não fiz o curso inteiro da licenciatura, fiz uma parte no Bacharelado (...). O } \\
\text { curso era integral e eu precisava de dinheiro, então comecei a trabalhar em } \\
\text { cursinho no plantão de dúvidas e na Estação Ciência. Lá tive contato com o } \\
\text { ensino e outras pessoas da Licenciatura. Adoro ciência, só que ao fazer } \\
\text { Iniciação e ir ficando mais velho no curso, comecei a entrar em contato com o } \\
\text { mercado de trabalho e o mundo acadêmico, então pensei que não era bem } \\
\text { aquilo que eu queria. E comecei entrar em crise sobre o curso. Nesse período, } \\
\text { alguns colegas da Licenciatura que já lecionava em escola pública me } \\
\text { convidaram para dar algumas aulas. Mas eu nunca tinha dado aula, mas a escola } \\
\text { estava sem professor desde o começo do ano e meu amigo me influenciou } \\
\text { dizendo que eu tinha "jeito" com os jovens, então me daria bem. Esse amigo } \\
\text { acrescentou que eu poderia sentir como é dar uma aula. Fiquei curioso e fui lá } \\
\text { conhecer a escola (...) essa experiência de sala de aula me "fisgou". Minha crise } \\
\text { veio em } 97 \text { e essa experiência em sala de aula me ajudou na escolha. }\end{array}$ \\
\hline Fermi & $\begin{array}{l}\text { Contato com } \\
\text { a sala de } \\
\text { aula/ensino }\end{array}$ & $\begin{array}{l}\text { Antes de ingressar na Licenciatura, enquanto estava no Bacharelado eu comecei } \\
\text { a dar aula em uma escola pública, assim percebi que na prática a pessoa que } \\
\text { tem a visão de Bacharelado, que nunca entrou numa sala de aula, acha que a } \\
\text { aula tem que ser de um jeito. O bacharel tem aquela visão... por exemplo, um } \\
\text { amigo físico que falava que a aula ideal tinha que ser igual àquela aula de } \\
\text { cursinho pré-vestibular, ele acha que aquilo é uma aula ideal, com continha e } \\
\text { que todos entendem, e essa é uma visão de um bacharel, não é a visão do aluno } \\
\text { do ensino médio. Mas eu senti isso em sala de aula, porque se você quer fazer } \\
\text { os alunos aprenderem alguma coisa, então tem que ter outras abordagens. } \\
\text { Abordagens que sendo Bacharel em Física, não te dá respaldo. A escolha pela } \\
\text { Licenciatura me ajudou nesse sentido. }\end{array}$ \\
\hline Planck & $\begin{array}{l}\text { Crise com o } \\
\text { Bacharelado }\end{array}$ & $\begin{array}{l}\text { Eu entrei no Bacharelado, fiz dois anos, e mudei para a licenciatura. Sentia-me } \\
\text { muito mal no Bacharelado. Não suportava mais pegar o livro e fazer } 30 \\
\text { exercícios. Perguntava-me o motivo de estar fazendo esse exercício repetidas } \\
\text { vezes. Acontecia nas aulas do Bacharelado de não entender o professor ou a } \\
\text { professora, mas se eu perguntasse, eles falavam "como assim, você não } \\
\text { entendeu, não é simples?" Eu falava, não, não é simples. Isso é algo que hoje ao } \\
\text { olhar para meus alunos, me pergunto se faço isso com eles - me policio } \\
\text { bastante. E quando eu mudei para a Licenciatura, a parte do início do curso eu } \\
\text { já tinha tido no bacharelado, então foquei nas disciplinas de educação, } \\
\text { principalmente as que são do IF. E eu gostei muito! Mas na Faculdade de } \\
\text { Educação também tiveram umas boas disciplinas que me marcaram bastante - } \\
\text { POEB e Metodologia do Ensino de Física. Essas duas me marcaram bastante } \\
\text { porque elas traziam abordagens bem diferentes sobre o ensino. Como eu tinha } \\
\text { uma visão de ensino muito tradicional, elas já conseguiram desconstruir muita } \\
\text { coisa dessa visão (...). Os professores nessas disciplinas levantavam questões } \\
\text { dentro da aula, que exigia reflexão. E ficamos nos questionando e isso motivava } \\
\text { a buscar mais conhecimento (...). Então deixei o Bacharelado por desilusão com } \\
\text { o curso, eu gostava muito de física, não queria desistir, queria dar uma segunda } \\
\text { chance. Mas no bacharelado não deu certo, então fui para o ensino, para a } \\
\text { Licenciatura para ver se o foco do curso mudava. E mudou totalmente. Percebi } \\
\text { que na Licenciatura abordava a Física que eu gostava, me motivava a aprender } \\
\text { e querer ensinar Física - do jeito que os professores na Licenciatura falavam que } \\
\text { era Física. }\end{array}$ \\
\hline Mayer & $\begin{array}{l}\text { Crise com o } \\
\text { Bacharelado }\end{array}$ & $\begin{array}{l}\text { Antes de prestar o vestibular, eu já pensava em fazer a Licenciatura, mas como } \\
\text { saí do Ensino Médio com uma visão ingênua sobre ensino, eu pensava que o } \\
\text { Bacharelado em Física era hierarquicamente superior a Licenciatura de modo } \\
\text { que, me formando no Bacharelado eu seria uma escolha melhor. Ser } \\
\text { pesquisador de física pura, trabalhar com física teórica, experimental, enfim, é }\end{array}$ \\
\hline
\end{tabular}




\begin{tabular}{|l|l|}
\hline & $\begin{array}{l}\text { muito melhor do que você pensar em como ensinar física. Parece que não se } \\
\text { passava pela minha cabeça que você tem que pensar na Física também para } \\
\text { ensinar, além de pensar em como ensinar. (...) No meio do ano passado eu } \\
\text { comecei a repensar isso. O Bacharelado estava me deixando muito chateada. } \\
\text { Daí eu desisti de vez e me transferi para a licenciatura (...). As aulas estavam } \\
\text { ruins (...). Em algumas disciplinas do Bacharelado, dependendo do professor, } \\
\text { ficava um coisa meio parecida, todas as aulas eram iguais (...) Eu já tinha } \\
\text { alguns amigos na Licenciatura que me contavam sobre as disciplinas do curso. } \\
\text { Então comecei a descobrir outras possibilidades de atuação, além de ser } \\
\text { professor: que os alunos da Licenciatura faziam Mestrado em Ensino, em } \\
\text { História da Ciência, por exemplo. E fui descobrindo coisas novas sobre a } \\
\text { Licenciatura vindo à Semana da Licenciatura. }\end{array}$ \\
\hline
\end{tabular}

\section{II) Apreciação geral dos sujeitos sobre a Licenciatura}

Quadro 11 - Falas sobre apreciação da Licenciatura

\begin{tabular}{|c|c|c|}
\hline Sujeito & $\begin{array}{l}\text { Tema: } \\
\text { Licenciatura } \\
\text { proporciona }\end{array}$ & Unidade de sentido \\
\hline Herschel & $\begin{array}{l}\text { Fornece base } \\
\text { geral. }\end{array}$ & $\begin{array}{l}\text { Eu acho que a Licenciatura tem que fornecer uma visão geral (...) fornece uma } \\
\text { base para você aprender e o conteúdo de física que a gente precisa e } \\
\text { desenvolver em aula, que é o que é mais importante (...) e eu sempre tive uma } \\
\text { tendência de buscar uma cultura geral (...). Não vou dizer que não aprendi } \\
\text { nada na Licenciatura, mas assim, conceitualmente, eu aprendi mesmo dando } \\
\text { aula e principalmente porque eu sou uma pessoa questionadora. Como eu sou } \\
\text { muito de ouvir, os alunos fazem pergunta, então eu aprendi muito com os } \\
\text { alunos. Por isso eu acho que tive uma base boa. Eu sempre soube responder } \\
\text { tudo, mas para isso você tem que preparar aula, foi uma coisa que aprendi [na } \\
\text { prática], porque até a linguagem é diferente. O que eu percebi foi que a } \\
\text { graduação me deu base para pensar. Por exemplo, porque Física Matemática } \\
\text { foi importante? Porque eu posso pegar qualquer assunto, leio, vejo a equação e } \\
\text { sei interpretar a equação, a conceituação você lê, então. Mas eu adoro } \\
\text { pesquisar, isso é importante, eu sabia onde estava a informação, e eu sou da } \\
\text { época que não tinha internet, então era livro, eu tenho uns livros, uma } \\
\text { biblioteca pequena por causa da graduação, mas que me ajudava também } \\
\text { (....). Nós no IFUSP éramos tratados de uma maneira muito madura, então não } \\
\text { tinha obrigatoriedade de entrar na sala de aula, mas a cobrança era alta, então a } \\
\text { gente tinha que estudar muito. Então, a autodisciplina aqui e a maturidade era } \\
\text { muito importante. }\end{array}$ \\
\hline Heisenberg & $\begin{array}{l}\text { Fornece } \\
\text { autonomia }\end{array}$ & $\begin{array}{l}\text { A USP me deu autonomia (...). Apesar de eu ter reprovado em algumas } \\
\text { disciplinas, acho esse processo importante para quem quer conseguir } \\
\text { realmente se virar na vida. Tanto que hoje em dia, se eu encontrar algum } \\
\text { problema [relacionado às aulas] pela frente e não ter ninguém para ajudar, eu } \\
\text { sei me virar. }\end{array}$ \\
\hline Maxwell & $\begin{array}{l}\text { Faltam } \\
\text { discussões } \\
\text { relacionadas à } \\
\text { epistemologia } \\
\text { e história }\end{array}$ & $\begin{array}{l}\text { Não cheguei a ver algumas discussões sobre Física Moderna, História da } \\
\text { Física ou aspectos epistemológicos, ou foi pouco. O que eu sei,eu li em muitos } \\
\text { livros e também fiz cursos em outros lugares (...). E assim vamos ganhando } \\
\text { elementos e se aprofundando. (...) Toda essa parte de física moderna e } \\
\text { contemporânea, evolução do universo, eu tive uma pincelada no curso, mas fui } \\
\text { aprender mesmo fora. Como vamos falar de física, se não falarmos sobre o que } \\
\text { física está fazendo hoje? Eu senti isso, saí do curso sem olhar para a física do } \\
\text { século XXI. Eu não conseguia falar nem da física do século XX direito. }\end{array}$ \\
\hline Feynman & $\begin{array}{l}\text { Gera } \\
\text { autonomia e }\end{array}$ & $\begin{array}{l}\text { Uma das coisas que o curso na USP gera pra gente é a questão de autonomia e } \\
\text { capacidade de adaptação (...). O conteúdo que estudamos em física, quando }\end{array}$ \\
\hline
\end{tabular}




\begin{tabular}{|c|c|c|}
\hline & $\begin{array}{l}\text { capacidade de } \\
\text { adaptação }\end{array}$ & 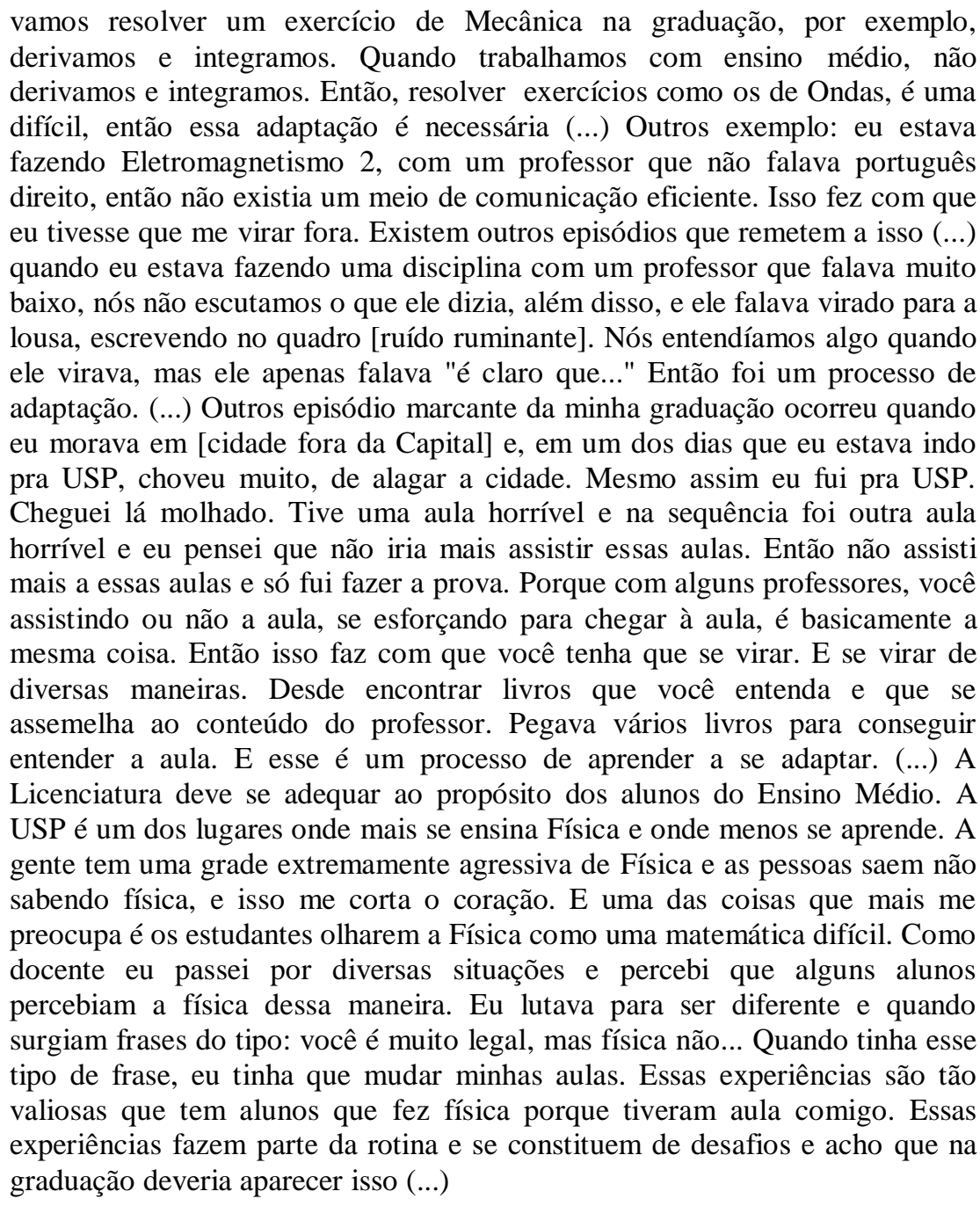 \\
\hline Gauss & $\begin{array}{l}\text { Proporciona a } \\
\text { construção da } \\
\text { autonomia }\end{array}$ & $\begin{array}{l}\text { Alguns professores são rudes. Um dia que uma aluna saiu chorando da sala, o } \\
\text { professor não se preocupou (...). Além disso, a lousa dele era rabiscos, } \\
\text { garranchos, garrancho pequenos, escrevia fraco (...). Quando alguém } \\
\text { reclamava, o professor era rude. (...) então das aula, eu não conseguia extrair } \\
\text { nada, estudava dos livros. Disso eu comecei a ter autonomia na graduação. } \\
\text { Tem um lado bom. Eu aprendi a estudar sozinho, aprendi algo? Não } \\
\text { totalmente, mas deu certo para ser aprovado. }\end{array}$ \\
\hline
\end{tabular}

\section{III) Início da atuação como professor de Física em escola}

Quadro 12 - Falas sobre início da carreira de professor

\begin{tabular}{|l|l|l|}
\hline Sujeito & $\begin{array}{l}\text { Tema: } \\
\text { conflitos do } \\
\text { início da } \\
\text { carreira }\end{array}$ & Unidade de sentido \\
\hline Herschel & $\begin{array}{l}\text { Fase de } \\
\text { preocupações } \\
\text { posteriores }\end{array}$ & $\begin{array}{l}\text { Só comecei a dar aula quando terminei a licenciatura. Eu estava me sentindo } \\
\text { muito segura e com uma concepção bastante idealizada de ensino. Então } \\
\text { comecei aplicando o GREF, recém-saído do forno e muito relacionado com } \\
\text { minha visão de ensino. Eu tinha todo o material. Mas aconteceu que, apesar } \\
\text { dessa segurança e idealização, comecei perceber as dificuldades. O GREF tem } \\
\text { muito de o aluno ir construindo os conceitos, e de repente eu me peguei }\end{array}$ \\
\hline
\end{tabular}




\begin{tabular}{|c|c|c|}
\hline & $\begin{array}{l}\text { Conflitos } \\
\text { relacionados a } \\
\text { questões de } \\
\text { currículo e } \\
\text { instrução. } \\
\text { Conflito } \\
\text { institucional } \\
\text { Escola como } \\
\text { formadora }\end{array}$ & $\begin{array}{l}\text { induzindo demais na busca pelas respostas [conceitos]. Chegava num ponto } \\
\text { em que os alunos aceitavam o que eu falava, ao invés de entenderem (...). } \\
\text { Outra dificuldade foi relacionada à questão de aprender a lidar com a realidade } \\
\text { de escola que é uma empresa. Tem cobranças e você tem que aprender a } \\
\text { trabalhar com isso e aprender a ter jogo de cintura. Existem diretores e outras } \\
\text { pessoas que vão cobrar (...). Conquistar o seu chefe, a coordenação, a direção e } \\
\text { provar que você faz um bom trabalho é muito exaustivo (...) E o grupo dos } \\
\text { professores criava um ambiente muito depressivo. As pessoas não estavam } \\
\text { envolvidas, era uma sala silenciosa, professores reclamando, isso me } \\
\text { desanimou a ser professora (...). Depois saí dessa escola e fui para outra mais } \\
\text { perto da minha casa e nessa nova escola a equipe era boa, muito engajada com } \\
\text { a educação e as discussões nas reuniões eram interessantes, então eu comecei a } \\
\text { ficar animada (...). E quando iniciei eu discutia com os alunos, "batia boca", } \\
\text { depois aprendi que não é certo (...). E a parte Pedagógica da minha formação a } \\
\text { graduação foi responsável por uma parte, mas a maior parte aprendi nas } \\
\text { escolas que eu trabalhei, nas boas escolas, com um bom Coordenador } \\
\text { Pedagógico. Ele também dá formação. }\end{array}$ \\
\hline Heisenberg & $\begin{array}{l}\text { Fase de } \\
\text { preocupações } \\
\text { Conflitos } \\
\text { pessoais } \\
\text { Conflito } \\
\text { institucional }\end{array}$ & $\begin{array}{l}\text { Eu lembro que no começo, as minhas aulas eram bem teóricas, não tinha } \\
\text { experimento, era mais tradicional. Eu lembro que tocava música clássica para } \\
\text { o pessoal ouvir, não sei por que eu fazia isso [risos] Eu tive uma professora de } \\
\text { física no colegial que era meu exemplo de como ser um professor. Ela era } \\
\text { autoridade sem ser autoritária. Eu buscava exemplos de como dar aulas nos } \\
\text { professores que tive no cursinho. Eles eram cínicos, faziam umas perguntas e } \\
\text { eles mesmos respondiam de uma forma engraçada, mas menosprezando os } \\
\text { alunos. Hoje não sou mais assim, mas na época da graduação para dar aula, eu } \\
\text { seguia algum desses professores. Às vezes dava certo, outras não. Tanto é que } \\
\text { hoje em dia eu sei que não devo partir direto para matéria nova sem antes fazer } \\
\text { uma revisão. Preparar o aluno para o conteúdo, fazendo perguntas que vão } \\
\text { instigando e acostumando o aluno. Na graduação nunca tinha visto isso, ou } \\
\text { visto alguém falar sobre outras formas de ensino. Se ouvi, esqueci. Era uma } \\
\text { escola pública que ficava longe da minha casa (...). Mas eu não tinha didática, } \\
\text { escrevia a fórmula na lousa e depois aplicava. Era passar o conteúdo, sem falar } \\
\text { bom dia, sem fazer uma brincadeira, uma piada, sem fazer analogia com um } \\
\text { problema, sem fazer transposição, sem dar exemplo do cotidiano. Eu tive uma } \\
\text { experiência péssima em uma escola. Eram alunos rebeldes e eu tinha aquela } \\
\text { mentalidade de passar as coisas na lousa e o aluno faz a prova sem consulta. } \\
\text { Aconteceu que os alunos começaram a conversar durante a prova, e eu briguei } \\
\text { com os alunos e com a direção, que não fazia nada. Em outra escola mudei da } \\
\text { água para o vinho. Porém essa nova escola era complicado, era noturno e fui } \\
\text { ameaçado de morte umas três vezes. }\end{array}$ \\
\hline Maxwell & $\begin{array}{l}\text { Fase de } \\
\text { preocupações } \\
\text { Escola como } \\
\text { formadora }\end{array}$ & $\begin{array}{l}\text { Como eu não tinha um percurso na licenciatura, eu não conhecia outras } \\
\text { metodologias, mas a diretora concordou que eu fosse dar aula. Fiquei seis } \\
\text { meses lecionando. Nesse momento eu não sabia fazer Plano de Aula, não sabia } \\
\text { fazer Diário, não tinha sido preparado para nada disso. Mas foi uma } \\
\text { experiência boa, dei aula para o Fundamental } 2 \text {, aprendi um monte de coisa } \\
\text { com os alunos e descobri que para ser professor necessitaria de uma } \\
\text { preparação. Quem ajudou nesse sentido foi a equipe de professores. Se eu não } \\
\text { tivesse tido essa experiência, de sala de aula, eu ainda acharia que qualquer um } \\
\text { poderia ser professor, bastando saber o conteúdo... Essa experiência me fez ver } \\
\text { isso. Por ser uma escola sócio construtivista, uma equipe de professores } \\
\text { bastante envolvida politicamente, isso me abalou. Pois com a crise do curso, } \\
\text { essa experiência me motivou. Acontece que na sala de aula reproduzimos } \\
\text { aquilo tudo que achamos legal da formação passada. Mas, como nunca tinha } \\
\text { tido uma discussão sobre avaliação, comecei a fazer discussões sobre } \\
\text { avaliação na escola, porque eu vi os professores nas htpc's fazendo discussões } \\
\text { sobre esse tema. Então eu percebi que eu não entendia nada. Eram propostas } \\
\text { muito interessantes, como trabalhar com RPG em sala de aula, por exemplo. }\end{array}$ \\
\hline
\end{tabular}




\begin{tabular}{|c|c|c|}
\hline & & $\begin{array}{l}\text { Era outro nível, e eu estava achando que prova era em papel. Aquelas coisas } \\
\text { que você fez na escola, vem para a Universidade, reproduz na Universidade } \\
\text { (...). Por isso eu falo que essa experiência que eu tive de } 6 \text { meses de "hardcore" } \\
\text { na escola, com um grupo preocupado com a educação, com uma equipe que se } \\
\text { preocupava comigo, por eu ser novo e sabiam que eu não era professor, eles } \\
\text { ajudavam na prova, nas atividades. Comecei o primeiro semestre super } \\
\text { tradicional e terminei de outra maneira. Eu fui incorporando naquele semestre } \\
\text { as coisas que eu estava discutindo com os colegas e isso fez a diferença na } \\
\text { minha formação. Mas eu não via isso nos colegas na licenciatura (...). Na } \\
\text { graduação fiz algumas discussões em Didática (sobre plano de aula, } \\
\text { avaliações, aulas não tradicionais). Fizemos em Elementos e Estratégias } \\
\text { muitas discussões sobre isso e em aulas de alguns professores que já faziam as } \\
\text { avaliações de formas diferenciadas e eles nos apresentavam outros aspectos da } \\
\text { avaliação. Mas o que mais marcou foi a vivência na prática. Quando eu dei } \\
\text { aula eu tive minha primeira experiência com formas diferenciadas de } \\
\text { avaliações isso me marcou e me chacoalhou. Nas disciplinas aqui ficou claro o } \\
\text { porquê daquilo estar sendo feito daquela maneira. Eu dei uma sorte de cair } \\
\text { numa escola com uma equipe muita boa e que fazia avaliações das mais } \\
\text { diversas formas e isso me influenciou profundamente. Na escola particular, } \\
\text { nós tínhamos que fazer uma prova tradicional, mas o restante, eu fazia das } \\
\text { mais diversas formas. Sempre valorizei o laboratório e ele fazia parte do } \\
\text { processo avaliatório. }\end{array}$ \\
\hline Feynman & 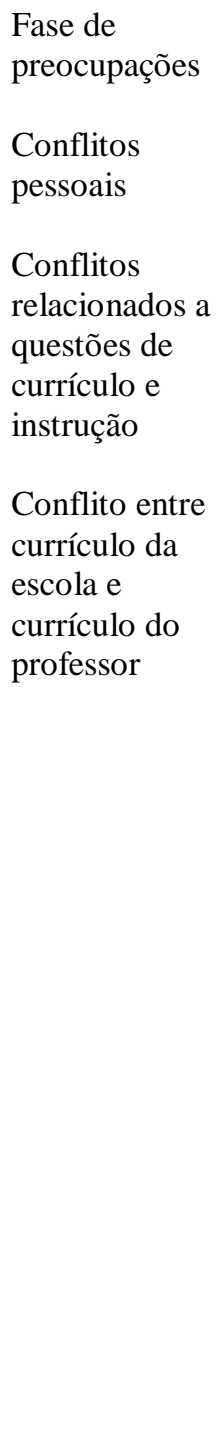 & 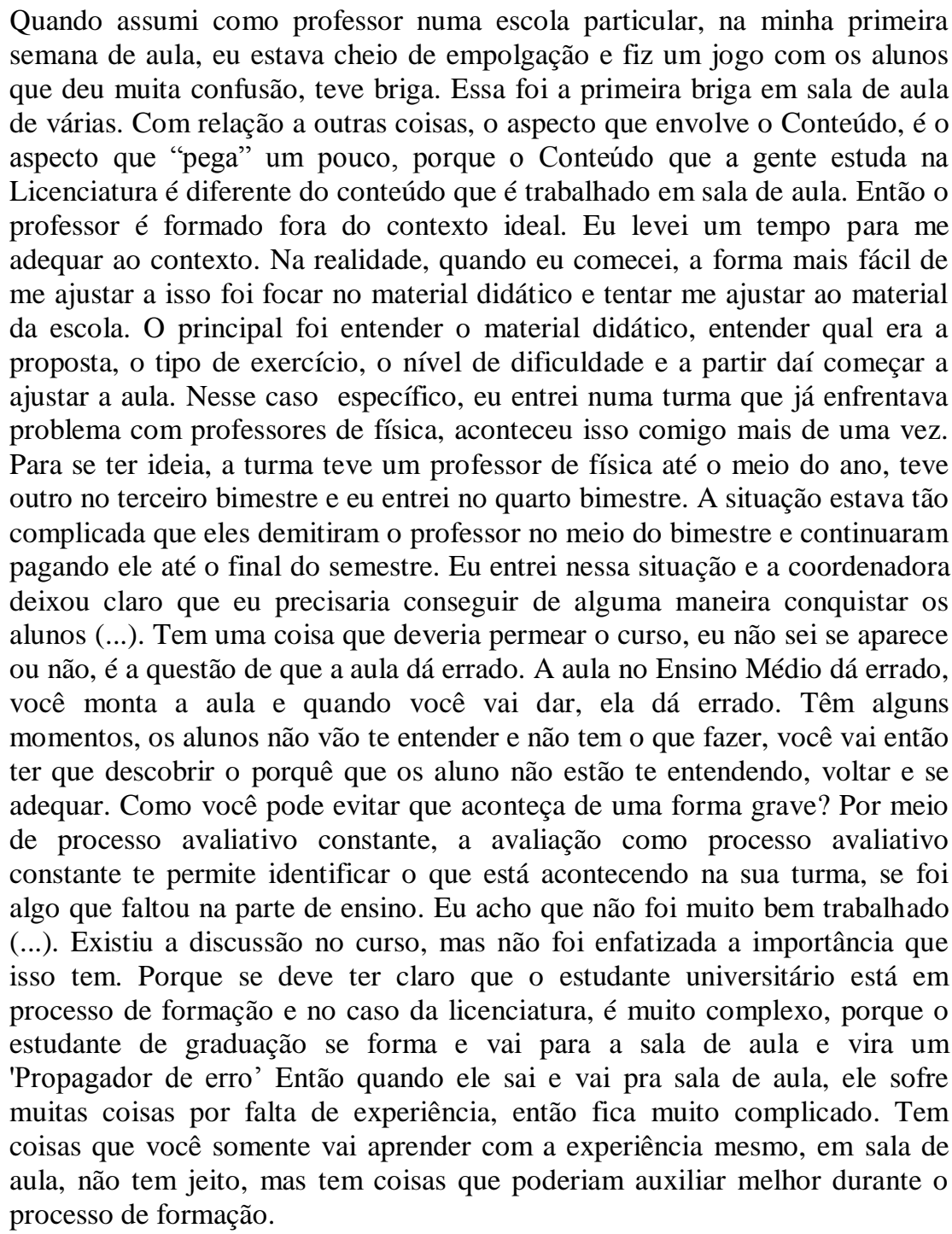 \\
\hline
\end{tabular}




\begin{tabular}{|c|c|c|}
\hline Fermi & $\begin{array}{l}\begin{array}{l}\text { Fase de } \\
\text { preocupações } \\
\text { posteriores }\end{array} \\
\text { Conflitos } \\
\text { relacionados a } \\
\text { questões de } \\
\text { currículo e } \\
\text { instrução }\end{array}$ & $\begin{array}{l}\text { Era uma escola estadual de periferia com condições ruins e quando comecei a } \\
\text { dar aula, saber entender como o aluno pensa, a gente entende, aprende na } \\
\text { faculdade, mas sinceramente, na minha opinião, tinha muita coisa que na } \\
\text { prática não se enquadram direito às teorias. As teorias vistas nas disciplinas de } \\
\text { educação não davam respaldo para o dia-a-dia em uma escola da periferia (...). } \\
\text { Eu lembro que quando eu dei uma prova individual, quando eu comecei, foram } \\
\text { um fiasco, notas vermelhas. Percebi que não funcionaria se eu desse prova } \\
\text { individual, então eu vi que nesse sistema, se eu quiser deixar a Física mais } \\
\text { quantitativa e prova em um nível maior, não dá. Então eu comecei a rever como } \\
\text { dar prova então eu passei a dar as provas com coisas mais parecidas do dia-a- } \\
\text { dia, com consulta ou em dupla. }\end{array}$ \\
\hline Planck & $\begin{array}{l}\text { Fase de } \\
\text { preocupações } \\
\text { posteriores } \\
\text { Escola como } \\
\text { formadora }\end{array}$ & $\begin{array}{l}\text { A maior dificuldade do início da carreira foi pensar o que os alunos pensavam. } \\
\text { Porque a ideia da aula é você tentar fazer ele aprender. Você tem um objetivo } \\
\text { ao dar aula. Através dessa aula eu vou querer que ele pensasse em como tratar } \\
\text { uma determinada lógica matemática e um conceito de física, trabalhar essa } \\
\text { lógica com ele. E é difícil você extrair essa informação do aluno, geralmente } \\
\text { você pede uma atividade, então dois alunos estão meio que fazendo junto, e o } \\
\text { professor não sabe se foi um ou se foi outro que conseguiu chegar no ponto da } \\
\text { questão. E é difícil o professor realmente compreender o que o aluno pensa e a } \\
\text { maneirado aluno resolver o problema. Essa é a pior parte, conseguir acessar o } \\
\text { que o aluno sabe ou não sabe (...). Eu tinha mais uma preocupação em como } \\
\text { ensinar minimamente a pensar como eu penso, a pensar o conteúdo, o jeito que } \\
\text { eu faço para resolver determinado problema dentro da física (...) Em relação ao } \\
\text { conteúdo, foi tranquilo, porque antes de começar a dar aula eu trabalhei como } \\
\text { plantonista, então era todo dia vendo todos os conteúdos de física do ensino } \\
\text { médio. Então a parte do conteúdo de ensino médio para mim não foi problema } \\
\text { nenhum (...) era uma escola com uma visão de ensino que não era tradicional. } \\
\text { Acho que a ideia que a Diretora implantou na escola era muito próxima ao que } \\
\text { a gente discute aqui [na graduação] sobre Educação, sobre Ensino de Física. } \\
\text { Por isso, não tive tantos problemas. A parte prática eu não sabia, mas a } \\
\text { Diretora foi dando todo apoio, muita coisa aprendi sozinho. A parte técnica, } \\
\text { por exemplo, o que você fazer com o aluno que não vai ser preparado para o } \\
\text { vestibular. Essa pergunta fica indo e voltando, o tempo todo: o que eu devo } \\
\text { levar para aula que não seja totalmente focado no vestibular, mas que os } \\
\text { alunos aprendam alguma coisa da Física. Qual o objetivo da aula dessa } \\
\text { semana, que é interessante para os alunos? Essa pergunta ficava o tempo todo } \\
\text { em mim. }\end{array}$ \\
\hline Gauss & \begin{tabular}{|l}
$\begin{array}{l}\text { Fase de } \\
\text { preocupações }\end{array}$ \\
Conflitos \\
pessoais \\
Conflito \\
instrução
\end{tabular} & $\begin{array}{l}\text { Eu comecei a dar aula semana passada, um dia só, é muito difícil pegar aula } \\
\text { com o "barco andando", porque o planejamento não estava correto. Isso foi um } \\
\text { problema, porque eu estava me pautando no planejamento. Mas, quando eu vi } \\
\text { o caderno do aluno, percebi que não poderia fazer o que eu tinha planejado. } \\
\text { Tive que dar um passo atrás, então foi difícil, no improviso, mas para amanhã } \\
\text { está tudo planejado (...). Uma coisa que eu não o gosto é que lá na escola eles } \\
\text { seguem um livro. Eu não vou conseguir terminar o livro. Eu queria que os } \\
\text { alunos tivessem um caderno, queria desenvolver junto com meus alunos o } \\
\text { nosso material, dar a lista, dar os textos. Então, estou preso a um livro, } \\
\text { digamos assim. O problema é que os alunos estão em defasagem. Então estou } \\
\text { tendo mais que voltar que adiantar (...). Para o primeiro ano eu vou falar } \\
\text { amanhã e quarta-feira do Movimento Circular. Eu queria montar uns } \\
\text { experimentos, mas não consegui montar nada. Não vou levar nada } \\
\text { experimental. Eu queria levar umas coisas de demonstração, só que eu não } \\
\text { consegui. E eu já dei lição de casa para eles, de modo que começarei a aula } \\
\text { fazendo com eles as tarefas que eu pedi: resolvendo os exercícios. E vou falar } \\
\text { vetorialmente, como é a Velocidade no MCU, o que é Aceleração Centrípeta } \\
\text { (...). Tenho muitas coleções de livros didáticos em casa, geralmente as aulas } \\
\text { que eu planejo são pontuais, nunca dou muita coisa numa mesma aula. } \\
\text { Primeiro eu estudo em várias coleções de livros, o que por um lado é bom, }\end{array}$ \\
\hline
\end{tabular}




\begin{tabular}{|l|l|}
\hline & $\begin{array}{l}\text { pois são todas iguais, por outro lado é ruim, porque eu queria expandir. } \\
\text { Dependendo do assunto, se eu conheço mais, eu olho no livro do ensino } \\
\text { superior, Para ter uma ideia um pouco mais complexa do assunto. Nem } \\
\text { sempre dá, até agora não deu. E o que eu faço no meu "caderninho" é tentar } \\
\text { montar como vai ser minha lousa. E de acordo com a lousa, eu já sei o que vou } \\
\text { falar, porque as ideias já estão frescas. Só que nem sempre dá tempo. Eu não } \\
\text { tenho o ritual ainda de, ao fim da aula, anotar onde eu parei. Mas se } \\
\text { desenvolve. O meu caderno é minha lousa. Esse é meu ideal de planejamento } \\
\text { de aula. O resto vai mais à intuição. E não estou preocupado com o que } \\
\text { pensam, eu dou aula com um caderninho na mão, se eles acham que eu sou } \\
\text { incapaz de decorar, não me importo, é a minha segurança. Eu vou conseguir } \\
\text { um dia ainda dar aula só com o que está na minha cabeça, mas ainda não } \\
\text { consegui chegar nesse ponto. Só que é muito difícil, a indisciplina na escola é } \\
\text { uma coisa absurda. É uma escola particular e estou dando aula numa coisa que } \\
\text { eles chamam de Curso Regular. Só que tem um Curso Especial que é para } \\
\text { alunos com Síndrome de Down, Autismo em vários níveis. E toda semana eu } \\
\text { entro na aula dos alunos mais velho, que tem Autismo, ali é muito bom, eles } \\
\text { ficam prostrados para você, à sua disposição, eles ficam interessados. Parecem } \\
\text { criancinhas. Os Alunos do Regular, eu imaginei que fosse ao contrário, entrei } \\
\text { com muito preconceito. Nessa turma tem o aluno indisciplinado e o arteiro, e } \\
\text { tem malandro. Alguns chegam a ser pedantes. Desrespeitosos, ainda mais com } \\
\text { professor jovem. Eles acham que eu sou um amigo, não sei como, mas eu vou } \\
\text { ter que dar algum jeito superar isso. }\end{array}$ \\
\hline
\end{tabular}

\section{IV) Disciplinas: Visões, opiniões, experiências e elementos marcantes}

\section{1 - Disciplinas de Física (conteúdo a ensinar)}

Quadro 13 - Falas sobre disciplinas da Física

Herschel

Ótica não tive na graduação. Aprendi mais dando aula e um pouco mais numa disciplina que fiz na PósGraduação.

Relatividade eu aprendi, por exemplo, num minicurso que tinha aqui.

Eu não gostava de Laboratório quando fiz na Licenciatura. As partes experimentais acabei desenvolvendo para dar aula. Eu fui aprender a fazer experimento, a dar aula de Laboratório de Física, quando eu trabalhei com um professor muito bom de Laboratório de Física, em uma escola. Ele era muito bom em Laboratório, então eu fui aprendendo a fazer experiência. O laboratório de física daqui é distante do laboratório que a gente tem na escola, então é outra história. O GREF acho que tem uns experimentos, mas eu diria que aprendi a dar aula de Laboratório trabalhando com esse professor. (...) A habilidade que desenvolvi por causa do Laboratório é o de saber operar alguns instrumentos, mesmo que fossem um pouco diferentes daqueles que trabalhamos nas aulas de Laboratório. Eu percebi isso quando eu fui dar aula de laboratório, eu estava muito insegura porque os equipamentos eram diferentes, mas eu tinha uma noção de operar (...) Então eu acho que quando a gente está na licenciatura, não sei por ter tido na escola do Estado, não tinha maturidade. E diferente, por exemplo, dos meus alunos que fizeram Laboratório na escola, eles tiveram dois anos de Laboratório de Física e de Química. Meus que colegas tinham feito escola particular para eles, era fácil o curso de Física. Era difícil para mim e os colegas de escolas mais fracas.

Física Aplicada com um professor que, o que ele falava na minha época é mesma coisa que e fala até hoje [sic]. Se você assistir as palestras, é a mesma coisa. Mas foi bom... 
Em Eletromagnetismo, mesmo sendo um curso de Bacharelado, cheio de matemática, mas, o professor procurou transcender em muitos aspectos e sair da caixinha. Ele discutia aspectos da religião judaica cristã e como isso influenciou o pensamento ocidental e, portanto, a ciência que a gente estuda. Então ele sai do conteúdo da Física, dialogando com outros conhecimentos e traz para dentro da Física. Isso é fascinante. Fora a própria estrutura do conteúdo do eletromagnetismo que tem uma beleza própria.

Quando eu entrei na Licenciatura, a primeira disciplina que eu fiz foi Gravitação, E me abalou. Vim para essa disciplina de Gravitação pensando que ia ser fácil. Mas o pessoal falava que essa tinha uma "pegada" [sic] histórica, e eu pensava que ia ser muito legal. Mas foi um "chute na cara". Divertido, porque eu nunca tinha pensado sobre isso, para você ver, no Bacharelado você vai estudando (mecanicamente), tem a beleza própria do conhecimento, mas não se se reflete sobre o conhecimento. Então o curso começa discutindo o conceito de gravidade. Você se pergunta como assim a gravidade não é a Newtoniana? Como assim? A gente não pára para pensar em gravidade Eisteiniana [sic]. Eu nunca tinha conectado o que eu estava fazendo com os modelos de gravidade. E essa questão de modelagem me pegou (...) a gente tem um curso de Gravitação no primeiro ano, com a abordagem histórica, mas depois não temos mais uma retomada daquilo [das discussões históricasepistemológicas]. Não conseguimos refletir. Fico me perguntando, quais influências que o curso aqui do Instituto de Física tem para só ter isso uma vez.

Alguns professores faziam os alunos refletirem sobre o papel do Físico. Os demais despejavam o conteúdo, lista de exercícios, prova. Eram matérias interessantes. Alguns tiravam dúvida, professore, mas não no sentido que eu aprendi a entender o Professor. Era no sentido que estava acostumado [na graduação]: uma pessoa que joga o conteúdo na lousa e os alunos tinha que se virar. Nas escolas básicas o professor deve ter outro perfil. Aqui eles não são professores, são pesquisadores que tem que dar aula. Infelizmente, aprendi o conteúdo que eles estavam apresentando, alguns virados para a lousa o tempo todo, tanto que tínhamos que esperar eles saírem da frente para você entender qual era a matéria do dia [risos].

Faltou na Licenciatura Física Moderna e Contemporânea. Nós não tivemos também Física de Partículas, por exemplo. Não sei se não tinha optativa, mas eu não vi nada nessa parte. Por exemplo, toda essa discussão sobre o Big Bang, Relatividade Geral, não vi nada disso. Nem como introdutório. Por exemplo, numa introdução sobre a Evolução do Universo com os alunos, usando o que aprendemos de Física Moderna e Contemporânea na graduação, não conseguiria. Eu dou. Aprendi depois. Mas, tem uma parte matemática que eu não sei. Eu senti isso, saí do curso sem olhar para a física do século XXI. Eu não conseguia falar nem da física do século XX direito. A gente tem na grade um curso de Laboratório e um curso de Física Moderna. Mas não foi um curso que foi discutindo epistemologicamente o que está acontecendo. Essa discussão, por exemplo, sobre o caminho epistemológico que aconteceu, eu fui ver depois, num curso de um colega da PósGraduação. Era um curso de Epistemologia e os Modelos da Física.

Eu fiz 4 laboratórios e a teve uma professora que se destacou, não estou falando que os outros professores eram ruins, mas se saia um aluno e entrava o outro, era a mesma coisa, eles consideravam os alunos todos iguais. Então eu cheguei ao final do Laboratório um e pensei que eu tinha passado o curso inteiro sem nunca ter feito uma reflexão do porquê de estarem coletando aqueles dados, como eles poderiam ser analisados. Pegamos a apostila, coletamos os dados, escrevíamos o relatório no padrão, mas sem nenhuma reflexão.

Feynman

Eletromagnetismo dois, foi com um professor que não falava português direito, então na aula não existia um meio de comunicação, e isso fez com que eu tivesse que me virar fora. Então tem outros episódios que remetem a isso. Então, voltando na grade, para o terceiro semestre, quando eu estava fazendo uma disciplina com um professor que falava muito baixo, então nós não escutávamos e ele falava virado para a lousa, escrevendo no quadro, nós só entendíamos quando ele virava e ele falava "é claro que..." era a única coisa que entendíamos. Como falei, eletricidade dois foi algo muito similar a isso. O curso de termo dois também foi um ritmo muito próximo.

Esse que falarei é um dos episódios marcantes da minha graduação (...) teve uma aula horrível e na sequência foi outra aula horrível. Pensei não ir mais assistir essas aulas. Então, não assisti mais a essas aulas e só fui fazer a prova. Porque com alguns professores, você assistindo ou não a aula, é basicamente a mesma coisa. Isso faz com que você tenha que se virar. E se virar de diversas maneiras. Desde encontrar livros que você entenda e que se assemelhava ao conteúdo do professor. Então eu pegava vários livros para conseguir 
entender o que estava no livro adotado pelo professor. E esse processo, é um processo que você se aprende a se adaptar.

Tivemos alguns cursos interessantes. Por exemplo, os cursos de uma determinada professora eram bons, pois ela tinha toda essa questão de trabalhar as concepções que os alunos possuem e discutir isso com a gente.

Óptica foi com um professor era meio "terrorista" e sempre que você falava alguma coisa sobre a Física ele indagava o porquê você está falando isso? Então você tinha que pensar muito antes de falar alguma coisa para não falar bobagem, era interessante porque você sabia que se falasse alguma bobagem ele iria voltar para você e você ia ter que repensar e reformular aquilo que você falou. A aula não era ruim. Pelo contrário, era interessante. Tinha umas coisas bem interessantes, por exemplo, de vez em quando tinha umas provas surpresa no fim da aula, então todo mundo ficava até o final da aula porque não sabia se ia ter prova (...). Alguns fazem coisas que você não quer colocar na sua prática e outros trazem coisas que você quer colocar na sua prática, às vezes com uma característica diferente, mas todo professor acaba trazendo alguma coisa positiva ou negativa. E no caso dele tinhas as duas coisas.

Como a vida universitária interfere na formação de um profissional, positiva ou negativamente, eu acho que a graduação precisa que os professores sejam mais humanos ao longo do processo. Um dos cursos mais tenebrosos que eu tive foi o curso de Física Moderna, um curso difícil, mas aprendi algumas coisas com essa professora. E uma das coisas eu aprendi com esta professora é ser coerente nas provas, a prova dela era difícil, mas era coerente com a aula, e isso é algo que não acontece, tem muitos professores que dão uma aula em um nível, mas cobra outro muito mais alto. No caso dela não, o nível de dificuldade era coerente com o que aprendemos.

Laboratório foram bem ruins, eu tive um laboratório que foi de Medidas, fazia porque tinha que fazer, mas não se refletia a respeito. Calculamos várias coisas, mas aquilo vira porcaria porque não faz sentido, não é trabalhado (...)

Porém o Laboratório de Mecânica foi muito legal. Foi no quarto semestre, o professor que trabalhou com a gente no laboratório de mecânica fazia com que os experimentos dessem errado. Tínhamos que entender o que deu errado, era proposital. O normal é o experimento dar errado e você forçar ele dar certo. Mas nessa aula, os experimentos já eram feitos para darem errado. Ali se desenvolvia o senso crítico.

O laboratório de eletromagnetismo foi muito legal, mas eu não aproveitei. Justamente porque o professor tinha uma boa proposta, mas não ficou claro o que era e quando ficou claro, o semestre acabou. Era a produção de um fotômetro. Construímos um fotômetro que mede a intensidade luminosa ao longo do dia, fizemos isso ao longo do semestre inteiro. Com a construção de vários tipos de fotômetros, usamos LED, até então, eu não sabia que o LED funciona como receptor. Tivemos uma série de coisas que foram legais, mas foram perdidas porque a proposta não estava clara

Fermi

Tive dois professores que me marcaram muito, que foi quando fiz Física 3 e 4 e Mecânica dos Fluidos. Me marcou profundamente porque os professores tinham uma aula profunda, uma didática diferente dos outros professores do IF e eu tento seguir a linha. Eles conseguiam explicar coisas pesadíssimas, mas era de um jeito que todo mundo ficava preso. Uma didática, uma simplicidade, como se estivesse dando aula para criança. Tanto que na lousa, quando resolvo exercício, eu vou passo a passo, justamente por causa deles. Vamos resolver essa equação: pegar na mão e não pular etapa. E consegui ter essa visão, através dessas disciplinas. Fazer passo a passo, quando você ia ver, estava aquela conta grande na lousa, mas quando você pegava o seu caderno para estudar, você conseguia entender as etapas.

O Laboratório, por exemplo, foi asqueroso. O que era para ser algo prazeroso era dilacerante porque os professores tornavam assim. A crítica que tenho ao IFUSP é a parte de experimental. Foi horrorosa, muito ruim. $\mathrm{O}$ instituto deve perder muitos alunos para outras áreas por causa do péssimo laboratório (...). Eu lembro que quando a gente ia para o laboratório, somente a barra de erro era valorizada e não o conceito. Preocupação grande com o erro, com a incerteza, eu ficava bravo, por exemplo, laboratório de física moderna conseguiu identificar alguma coisa, mas era uma preocupação em excesso com a parte estatística e ninguém 
te orienta. E o instituto tem essa cultura de perfeccionismo, mas com equipamentos antigos que falharam. (...) Eu sempre era péssimo. Tinha alguém que montava e a gente só apertava o botão. Você chegava na bancada e já estava montado. Tinha meu colega de laboratório e ele fazia as coisas. Era uma tortura, acho que 10\% ou menos dos alunos achavam bom o laboratório. E acho que eles já tinham habilidade com isso. era uma matéria de caráter punitivo. Semestre de laboratório era de morte porque eu sabia que não aprenderia nada e iria passar sofrendo. Faltam professores bons de laboratório e acho que na licenciatura, a opinião era a mesma.

Planck

Nas disciplinas da Física, parece que a distância entre o aluno e o professor é enorme. Se você tem uma dúvida, parece que problema é do aluno. O aluno tem que se virar [sic] para descobrir, para sanar a dúvida. Ou ainda, os professores passam a impressão de que se o aluno tem dúvida porque não estudou o suficiente. Este é o discurso básico dessas disciplinas.

Acho que a disciplina de Física Moderna ficou muito mais próxima da Física do Bacharelado do que da Licenciatura. Mas ainda assim o professor conseguia levar alguns aspectos da educação. Não eram puramente conta e coisas do tipo. Ele discutia os fenômenos e conceitos da Física Quântica, mostrava os cálculos. Tratamos alguns fenômenos com bastante cálculo, mas não tanto quanto no Bacharelado, mas algumas aulas ele trazia um aspecto mais, num era histórica, era mais experimental acho, numa abordagem mais prática. (...) não tinha tanto uma relação com ensino, acho que seria legal, inclusive o professor dessa disciplina, tratar um pouco da Física Moderna dentro do contexto do ensino básico, e isso não aconteceu. Essa abordagem ou discussão não teve, talvez seja por isso que eu tenha achado que tenha ficado mais perto do Bacharelado. Mas envolve toda uma questão curricular, não sei se o professor teria paciência para discutir tudo isso, é muita coisa, porque você fala: e no ensino, como é que é? E isso torna a discussão muito longa.

Eu acho que o que mais eu aproveitei foi o Laboratório de Eletromagnetismo, que é justamente de onde eu tirei algumas das ideias para aplicar em sala, as outras, Moderna 1 eu não me lembro de quase nada, eu lembro que tinha um ou outro experimento, as raias espectrais e coisas do tipo. Laboratório de física 1 e 2 não lembro nada, eu lembro como fazia algumas coisas, lembro como a gente fazia determinadas coisas, determinar a aceleração da gravidade, lembro que tinha a bolinha caindo, determinar a escala. Elas não traziam nada de discussão voltada para dentro do ensino médio, era aprender física experimental (...). Acho que a maioria das coisas... Foi mais ou menos nessa pegada. A gente fazia os experimento, calculava a equação da onda, geralmente era uma incógnita que você ia atrás e geralmente com essa equação você chegava naquela incógnita, era mais uma parte matemática do que uma parte física de entender o que estava acontecendo ali fisicamente. Acho que foi isso, foi essa impressão que eu acho que eu mais tive dos labs assim. Eles queriam que você aprendesse a trabalhar com equações e tentar a relacionar aquelas equações com o equipamento, os relatórios eram desnecessários. Eram relatórios imensos que na hora você sabia o que você estava fazendo, mas dois meses depois você não sabia mais nada.

Gauss

Na graduação eu achei ruim a disciplina de Óptica, eu não tive nada de ótica no Ensino Médio, então tive que estudar por conta. Além disso, alguns professores são rudes. Um dia que uma aluna saiu chorando da sala, o professor não se preocupou (...). Além disso, a lousa dele era rabiscos, garranchos, garrancho pequenos, escrevia fraco (...). Quando alguém reclamava, o professor era rude. (...) então das aulas, eu não conseguia extrair nada, estudava dos livros. Disso eu comecei a ter autonomia na graduação. Tem um lado bom. Eu aprendi a estudar sozinho, aprendi algo? Não totalmente, mas deu certo para passar. Tanto que tinha uma senhora na minha sala, que entrou comigo na graduação, de uns 60 anos. Um dia ela pediu ao professor para que ele escrevesse com a letra maior, no entanto, o professor, ao invés de aumentar a letra mandou que ela se sentasse na cadeira dele "para ficar mais pertinho da lousa", e disse ainda "não vou escrever maior não, é o meu jeito". E ele não dava explicações. A disciplina esvaziou depois do primeiro mês que tem trancamento parcial.

Tudo de Física Moderna e Contemporânea não foi satisfatório. Eu sinto que não sei nada. Sinto que não sei nada de Física Moderna, porque o curso que fiz aqui foi totalmente canônico, totalmente formal, em termos de não ter sido mais nada além de conta. Se você perguntar pra mim o que é dualidade onda-partícula eu não sei 
te dizer, só que eu sei escrever a equação do comprimento de onda de De Broglie. Eu sei as Equações do Efeito Fotoelétrico. Eu sei as equações das coisas, mas conceitualmente, na graduação foi totalmente deficiente.

Complementos de Mecânica fizeram com uma professora que no Bacharelado é adorada (...) ela sempre deu Mecânica 1 ou Mecânica 2 e ela veio dar a disciplina para a Licenciatura, mas acho o curso muito ruim. Não porque ela é uma professora ruim, mas ela não conseguia se comunicar com os alunos. Além disso, por ser muito formalista, apesar de muito entusiasmada com a matéria, ela focava a aula em um tipo de raciocínio apenas. Tanto que em algumas aulas ela se recusou a fazer alguns exercícios. Ela alegou que não teríamos capacidade matemática para isso. Isso demonstra que ela não está entendendo o público dela, não está tendo empatia e nem humildade. Ela não teve condição de pensar que quem ela está formando são professores e ela não deveria agir assim com professores.

Introdução às Medidas fiz numa época que não tinha professor, então quem me deu foi um aluno de doutorado, só que foi incrivelmente bom o curso. Uma pessoa aberta, ao invés de dar aula daquele como se fosse uma lecture, uma palestra, ele se sentava ao nosso lado, ajudava a resolver os exercícios. Era uma relação como se ele fosse minha dupla de laboratório, Ele era a pessoa que ajudava a compor "o trio". Ele ajudava todo mundo, e isso fez muita diferença (...). Provavelmente não era um professor que conhecia teorias pedagógicas ou métodos inovadores de ensino. Apesar disso ele compreendia o que era o mínimo para estabelecer uma relação de ensino-aprendizagem: ele tinha empatia e interesse. E quando a pessoa tem interesse, ela vai tentar do jeito que for fazer com que você entenda aquilo. E ele conseguia isso. E tinha vezes que eu falava: não entendi. E ele se sentia incomodado de não estar conseguindo se comunicar comigo. E é uma coisa que falta em muitos professores, e é legal, ele é aluno de doutorado, que é sinal de que se ele virar professor aqui um dia, vai ser um a menos na lista dos ruins.

Aqui! Aqui sim ouve o que você perguntou [sobre ter elementos da profissão de professor na aula], em Mecânicas dos Corpos Rígidos e dos Fluidos. Eu fiz com a professora que hoje é minha orientadora. Essa disciplina tem crédito de trabalho e nos créditos de trabalho dela, ela dava atividades experimentais que a gente fazia virtualmente, então era meio que assim, às vezes a atividade é numa sala mesmo, experimental de fato, às vezes era virtual. E ela tem isso, de falar. Ela não é da área de ensino, mas ela é muito bem informada e muito entusiasmada. Ela não tem experiência em educação básica. Mas ela sempre tenta transmitir para os alunos as dificuldades e problemas epistemológicos até dos cursos de antigamente, então ela deu muitas vezes esse curso. Mas esse curso de mecânica ela reformulou, mudando a ordem dos assuntos, pulando assuntos, introduzindo assuntos, ela tem hoje estabelecido um caminho epistemológico para a disciplina e como o conhecimento vai evoluindo que não está em nenhum livro, é dela, apesar de usar livro texto.

Gravitação era para ser um curso com um viés histórico, mas eu fiz o curso com um professor da Física Matemática. O curso foi basicamente aprender a manipular equações. Tanto que ele tentou, mas não deu certo, falar de teoria de perturbação. Nem sei direito o que é isso, e uma coisa que ele fez foi deduzir com cálculo as Equações de Kepler, que é uma coisa que fui ver direito e que entendi somente em Complementos de Mecânica. Foi terrível, acho que é um erro dar esta disciplina a pessoas que não sejam da área da História da Ciência. Acho que é um erro institucional e estrutural.

\section{Mayer}

Quando eu estava no meu segundo ano [ainda no Bacharelado] eu fiz a disciplina de Relatividade na Licenciatura. Eu estava fazendo Física 2, disciplina que tem como conteúdo Oscilações e Ondas, Termodinâmica e Relatividade. Então, me matriculei em Relatividade da Licenciatura porque eu pensei que eu não ia entender direito a Relatividade no curso de Física 2 , mas era um conteúdo que eu queria entender (...) Aconteceu que de fato eu não entendi Relatividade em Física 2. Eu entendi relatividade no curso ofertado para a Licenciatura. Ou seja, eu entendi Física 2 porque eu já havia feito Relatividade. Muitas vezes eu comparava as duas aulas e pensava que o professor na disciplina de Física 2, poderia explicar de várias maneiras diferentes, com abordagens melhores e mais adequadas do que aquela que ele estava fazendo. Têm disciplinas de física que dependendo do professor, fica algo coisa meio parecida sempre.

Tem disciplinas de Física que dependendo do professor, fica uma coisa meio parecida. Em Física Moderna 2 para a Licenciatura, deu para entender mais ou menos, parece uma matéria do Bacharelado, mesmo eu fazendo essa disciplina na Licenciatura e apesar dela ser obrigatória não tinha muita diferença daquela do 
Bacharelado. Por exemplo, Física 4, que fiz no Bacharelado, o professor explicava bem. Então, não sei se tem muita diferença entre as disciplinas do curso de Bacharelado em Física e do curso de Licenciatura em Física. Parece que só tem diferença quando o professor olha para a disciplina, parece.

Parece que os alunos da Licenciatura tem um olhar mais para como está sendo a aula do professor e os do Bacharelado não tem. Isso é um problema muito grave do bacharelado, porque às vezes tinha vários problemas das aulas dos professores que me incomodavam, mas não porque eu tinha um olhar para a aula, mas porque tinha era difícil de entender o professor, não ficava claro o que seria cobrado na avaliação, então além de do olhar para a matéria que se está aprendendo, os alunos da licenciatura têm uma postura mais crítica em como isso está sendo ensinado pelo professor. Em física 2 [no curso do Bacharelado] eu e meus colegas achávamos que o professor explicava muito mal, que era muito difícil de entender, mas tinham muitos alunos que consentiram com essa postura. Já na Licenciatura, quando eu fiz Moderna 2, não senti tanto isso. Por exemplo, estava tendo um problema também, pois moderna 2 é muito densa e são conteúdos que são muito complexos, e os alunos sentiram que o professor estava indo rápido, então acabou tendo muita gente no movimento de falar para o professor que está rápido. Curiosamente, as pessoas que estavam nessa mesma aula e impunha um ritmo mais acelerado a aula, eram pessoas que paravam a aula para falar com o professor sobre assuntos que ele ainda não tinha comentado e esses mesmos alunos insinuavam que já estavam entendendo, isso é algo vi acontecer com alunos do curso de Bacharelado em Física. São pessoas do Bacharelado que estavam fazendo Moderna 2, da Licenciatura, como optativa e eletiva, e ficavam adotando posturas que incomodavam nós, da Licenciatura.

Somente na disciplina de Gravitação a professora discutiu ou levava aspectos do ensino de Física para a aula. Gravitação não é sobre o Ensino de Física, é uma matéria de história e tem um pouquinho de Física, mas vamos vendo historicamente como as teorias da Gravitação e a matemática foram se desenvolvendo ao longo da história. Não é propriamente de ensino, mas durante a aula a professora vai falando: isso aqui é um método de ensino que a gente conhece capaz de ajudar aluno com tal coisa ou que ajuda o aluno do Ensino Básico a entender tal ponto. Por exemplo, teve uma vez e a professora deu para nós umas folhas para fazermos as elipses e desenhar os pontos das órbitas dos planetas com alfinetes e com um cordão, Método do Jardineiro, colocar duas estacas e fazer a elipse com corda, com o objetivo de olhar a elipse e olhar para as órbitas e saber que apesar de fazermos elipses, elas parecem circulares. Então ela passou isso para começar a falar de Kepler e no final ela falou: se vocês olharem vocês pensam que são elipses? Não, é um círculo! Por isso que as pessoas achavam que as órbitas eram circulares.....e no meio disso ela falou que isso era um método que poderia usar com os alunos. Os outros professores não tem isso.

Laboratório é um problema. Quando eu fiz foi muito caótico. Primeiro, nós nunca sabemos direito o que estamos fazendo. A introdução da aula é uma apresentação de slides, com o professor falando mais ou menos sobre a teoria, é assim porque nós devemos observar o que vai acontecer a partir da teoria. São-nos dados experimentos "prontos". É-nos dado numa folha tudo o que devemos fazer: ligar tal botão, posicionar tal coisa em tal lugar, medir tal coisa xis vezes, construir gráfico disso por isso e ajustar o gráfico com base em tal teoria. Mas, mesmo assim, não entendamos nada. Algo que aprendi que fez diferença foi montar circuito. Porque quando eu vi isso no ensino médio ou em Física 3 ou 4, vemos o desenho lá, mas nunca imaginamos como aquilo fica com os fios. E o laboratório proporcionou, pela primeira vez, a possibilidade de montar os circuitos que vemos somente em desenhos, onde é tudo um quadradinho perfeito, retinho: resistores, lâmpadas, etc. Sabemos onde está tudo, mas quando vamos montar, não sabemos direito como trabalhar com isso. Em laboratório, no começo eu tinha muita dificuldade em como montar um circuito paralelo e algo que eu percebi é que é muito mais intuitivo você entender um circuito em paralelo quando você está com os fios brincando e você descobre aquilo dos três nós. Faz toda diferença. Você montar um circuito, pensando que não está em paralelo ou não e não dá certo o que você queria.

\section{2 - Didática da Física}

Quadro 14 - Falas sobre disciplinas da Didática da Física

\section{Herschel}

Natureza

epistemológica

Instrumentação do Ensino de Física, o professor dava a parte de História da Ciência. Eu acho que foi muito eficiente no meu curso, eu tive uma formação, uma base de Epistemologia e história da Ciência e Filosofia da Ciência. 


\begin{tabular}{|c|c|}
\hline & $\begin{array}{l}\text { Tecnologia do Ensino } 1 \text { e } 2 \text {, eu não sei direito o que eu aprendi. Foi dado por um } \\
\text { professor que era meio lenda no IFUSP [sic]. Outro dia me perguntaram se eu tive aula } \\
\text { com esse professor. Eu falei que tive então o que eu aprendi? Não sei, não lembro. }\end{array}$ \\
\hline \multirow[t]{2}{*}{$\begin{array}{l}\text { Natureza } \\
\text { metodológica }\end{array}$} & $\begin{array}{l}\text { O meu curso de Prática em Ensino, acompanhávamos os alunos da Faculdade de } \\
\text { Educação. Fazíamos uma aula experimental que era gravada. Depois era discutida. } \\
\text { Então, de uma maneira geral, apesar do meu curso ter sido meio conturbado, eu saí me } \\
\text { sentindo segura para dar aula. Prática de Ensino para mim foi fundamental, eu } \\
\text { valorizava muito a aula, lia todos os textos, isso me ajudou bastante para trabalhar em } \\
\text { sala de aula. Saí desse curso sentindo isso. Mas não era nesse molde de assistir } 5000 \\
\text { aulas. A professora trabalhava dando parte da aula a teoria e a outra parte era Estágio. } \\
\text { Em grupo dávamos aula e a professora gravava. E esse vídeo era mostrado em aula e } \\
\text { discutido entre todos os alunos. E tinha ainda um trabalho com os alunos da Faculdade } \\
\text { de Educação. Na Faculdade de Educação lemos os textos e discutimos os casos e os } \\
\text { vídeos, mas eram textos de situaçães que a gente pode encontrar em sala de aula. Eram } \\
\text { textos de ensino de Física ou de Conteúdo. Mas eu acho que hoje é um exagero de } \\
\text { observação de aula, acho isso um absurdo, não aprendemos nada só observando aula. }\end{array}$ \\
\hline & $\begin{array}{l}\text { Então, o professor dava aula com instrumento simples. Com coisa do dia a dia mas, no } \\
\text { ano que eu fui fazer, todo mundo queria fazer com o ele, porque ele bolava umas } \\
\text { experiências super legais com coisas super simples. E ele foi para França, daí eu fiz com } \\
\text { essa professora que estava entrando, e eu gostei mais ou menos. }\end{array}$ \\
\hline
\end{tabular}

\begin{tabular}{|l|l|}
\hline Heisenberg & \multicolumn{2}{|l|}{$\begin{array}{l}\text { Natureza } \\
\text { metodológica }\end{array}$} & $\begin{array}{l}\text { Em uma disciplina de Ensino de Física [não se lembra de qual] o professor fez um } \\
\text { histórico dos projetos que ocorreram aqui no Brasil, me ensinou como se monta uma } \\
\text { apostila. Por exemplo, falou para escrever uma apostila como se estivesse conversando } \\
\text { com o leitor; E a gente vê como são poucos os livros que fazem isso. Quando eu lia as } \\
\text { apostilas que ele escrevia, era muito gostoso. }\end{array}$ \\
\hline $\begin{array}{l}\text { Natureza } \\
\text { metodológica }\end{array}$ & $\begin{array}{l}\text { Na disciplina de Práticas do Ensino eu tive a chance de fazer um estágio em um } \\
\text { programa para ensinar para os funcionários da USP que não tiveram chance. Então eu } \\
\text { dava aula de Física para os últimos no Laboratório de Física da Faculdade de Educação. } \\
\text { Para mim foi muito bom, pois esse projeto tinha o acompanhamento de uma professora. } \\
\text { Era um paraíso, pois eu tinha acesso ao laboratório e às experiências. Eu podia fazer } \\
\text { praticamente qualquer experiência que eu quisesse e tinha o acompanhamento da } \\
\text { professora. Eu montava uma aula e perguntava para ela se estava bom. Eu tinha todos os } \\
\text { instrumentos que precisava e um apoio teórico por trás disso. }\end{array}$ \\
\hline
\end{tabular}

\begin{tabular}{|l|l|}
\hline \multicolumn{2}{|l|}{ Maxwell } \\
\hline $\begin{array}{l}\text { Experimentos de } \\
\text { Baixo } \\
\text { custo/natureza } \\
\text { metodológica }\end{array}$ & $\begin{array}{l}\text { Gostei muito das disciplinas de educação, mas as que me ajudaram na minha formação } \\
\text { como professor e me pegaram de outro jeito foram as disciplinas que eu fiz aqui da } \\
\text { Didática da Física (...). Fiz uma disciplina em que fazíamos montagens experimentais } \\
\text { (...). O professor fazia a gente refletir sobre a questão experimental em sala de aula, com } \\
\text { muito material de baixo custo, e eu que estava lecionando em escola pública... toda } \\
\text { aquela preocupação que a gente tinha de fazer o Laboratório do Bacharelado, cheio de } \\
\text { equipamentos, eu ficava pensando como eu vou transpor isso para a escola? Então essa } \\
\text { disciplina ajudou muito nesse aspecto, descobrimos um mundo. }\end{array}$ \\
\hline $\begin{array}{l}\text { Contato com a } \\
\text { produção } \\
\text { acadêmica da } \\
\text { pesquisa em } \\
\text { Ensino de Física }\end{array}$ & $\begin{array}{l}\text { Elementos e Estratégias. Elementos e Propostas e Projetos foram as que me } \\
\text { apresentaram para outro mundo que eu não conhecia que é a Pesquisa em Ensino De } \\
\text { Física. Se hoje estou na Pós-Graduação, é por causa dessas disciplinas. Eles discutiam e } \\
\text { traziam artigos das revistas, tais como o Caderno Catarinense, da Revista Brasileira de } \\
\text { Ensino de Física... E nós descobrimos que aquilo [ensino] se pesquisa e tem gente que } \\
\text { está produzindo esse tipo de conhecimento! Apesar de ter tido um pouco disso na }\end{array}$ \\
\hline
\end{tabular}




\begin{tabular}{|l|l|}
\hline & $\begin{array}{l}\text { disciplina [suprimido], a discussão lá era muito teórica. Mas agora começamos a ver que } \\
\text { tinha mais que isso, e eles estavam produzindo há mais de 10 anos material sobre Ensino } \\
\text { e sobre atividades em sala de aula. Então essas disciplinas me abalaram nesse aspecto. }\end{array}$ \\
\hline $\begin{array}{l}\text { Análise crítica de } \\
\text { livros } \\
\text { didáticos/natureza } \\
\text { metodológica }\end{array}$ & $\begin{array}{l}\text { Propostas e Projetos: essa disciplina abriu outra vertente, de onde nasceu o meu projeto } \\
\text { de mestrado. Lá estudamos PSSC, GREF, etc. Que são todas uma produção viva de } \\
\text { currículo, propostas e atividades em ensino além do livro didático. Agora, nos últimos } \\
10 \text { anos aconteceram uns modificados nos livros por causa do PNLD. Mas naquela } \\
\text { época, o livro didático era incipiente. Então naquela época, os livros eram muitos iguais. } \\
\text { Você tinha o Ramalho, você tinha outro, tinha somente a Beatriz que era diferente, e eu } \\
\text { tinha uns colegas que não gostavam, achavam que o livro da Beatriz tinha muito texto, } \\
\text { mas tinha uma discussão teórica e de história que não nos tinha outros livro. E hoje nós } \\
\text { temos diversos livros, com diversas propostas de ensino e antes não tinha. Então } \\
\text { descobrir aquele mundo de propostas, foi fantástico. Descobrimos que poderíamos sair } \\
\text { da caixinha, descobrimos, por exemplo, que não precisávamos começar com cinemática } \\
\text { as aulas do primeiro ano. }\end{array}$ \\
\hline
\end{tabular}

Feynman

Faltou discussão sobre

Acho que a questão que envolve experimentos voltados para o Ensino Médio é muito experimentos/natu reza metodológica frágil graduação. Por ser um curso voltado para docentes em especial para o ensino básico, acho que deveria ter uma prática que trabalhasse essa questão. Os laboratórios didáticos que a gente tem são da Física, então a parte de didática, produção de material e experimentos era algo que não deveria ser optativa, deveria ser obrigatória e permear o curso inteiro. Pois é algo que você só constrói ao longo do tempo.

faltou discussão sobre a

Tem uma coisa que deveria permear o curso, eu não sei se aparece ou não, é a questão de que a aula dá errado. A aula no Ensino Médio dá errado, você monta a aula e quando avaliação/natureza metodológica você vai dar, ela dá errado. Em algum momento, os alunos não vão te entender e não tem o que fazer você vai então ter que descobrir o porquê que os alunos não está te entendendo, voltar e se adequar. E isso é uma coisa que...Como você pode evitar que aconteça de uma forma grave? Por meio de processo avaliativo constante que te permite identificar o que está acontecendo na sua turma, se foi algo que faltou na parte de ensino? Eu choque não foi muito bem trabalhado. E física é tenso porque se você deixar para avaliar só no final do processo, então... Existiu a discussão no curso, mas não foi enfatizada a importância que isso tem. Porque se deve ter claro que o estudante universitário está em processo de formação e no caso da licenciatura, é muito complexo, pois ele se forma e vai para a sala de aula e vira um 'Propagador de erro'. Então quando ele sai e vai pra sala de aula, ele sofre muitas coisas por falta de experiência, então fica muito complicado.

Docentes não têm conhecimento Tem coisas que você somente vai aprender com a experiência mesmo, em sala de aula, não tem jeito, mas tem coisas que poderiam auxiliar melhor durante o processo de prático da escola básica/natureza metodológica formação. Uma das maneiras de resolver isso, que foi algo que eu senti falta no curso, é a maneira como é pensado o Estágio, que eu acho que a universidade é pensada de uma maneira que ela só olha para dentro dela mesmo. Por exemplo, nós temos docentes que trabalham a questão de ensino, mas nunca estiveram numa sala de aula. A universidade contrata docentes para o Ensino que nunca trabalharam em sala de aula. Isso para mim é estranho. Então, eu sou um docente que vai formar licenciados para atuarem junto ao Ensino Médio, mas que nunca entrou numa sala de ensino médio, isso é sinistro. Muitas dessas coisas podem ser que aconteça porque muitos professores do ensino não conhecem a escola. Por exemplo, muitos professores se formaram no Bacharelado e perceberam que ensino é uma coisa legal e começaram a ir pro ensino. Mas isso não significa que a grade foi pensada de acordo com o que é necessário para o Ensino. 


\begin{tabular}{|c|c|}
\hline $\begin{array}{l}\text { Natureza } \\
\text { cognitiva do } \\
\text { ensino de } \\
\text { ciências/natureza } \\
\text { metodológica }\end{array}$ & $\begin{array}{l}\text { Na Faculdade de Educação o que ajudou foi Metodologia de Ensino } 1 \text { e } 2 \text {, em que eu } \\
\text { percebi que ali sim ajudava, era relacionado com a Física. A gente tinha um estágio mais } \\
\text { pesado, com mais tempo em sala de aula. A professora dava respaldo, como o aluno } \\
\text { pensa e essas coisas. Mas era numa abordagem construtivista, que é uma abordagem } \\
\text { dificílima, que você não consegue aplicar numa sala de aula real. O construtivismo, } \\
\text { você consegue aplicar com } 2 \text { ou } 3 \text { alunos. Em condições ideais, em que eu brinco "em } \\
\text { condições termodinâmicas ideias" que aí você consegue explorar mais, mas não com } 40 \\
\text { alunos, dos quais } 25 \text { estão conversando e não estão dando "bola" para você. E mesmo } \\
\text { assim, era difícil aplicar, por exemplo, numa sala de aula do estado. }\end{array}$ \\
\hline $\begin{array}{l}\text { Natureza } \\
\text { metodológica }\end{array}$ & $\begin{array}{l}\text { Tecnologia do Ensino de física era uma disciplina legal, porque o professor era muito } \\
\text { prático. E isso me ajudou a querer ser mais prático e mais objetivo no ensino. Por } \\
\text { exemplo, não dar uns exercícios muito elaborados. Ele também dava exemplos de como } \\
\text { era o ensino em outros países, como era na China, por exemplo. Aqui no Brasil ele } \\
\text { brincava sobre MU e MUV. Então você começa a ver que ensinar MU e MUV, } \\
\text { sorvetão, gráficos, etecetera é um besteirol gigante. (...) E isso eu procurei levar para as } \\
\text { minhas aulas, comecei dando exercícios mais curtos, mais objetivos, que de certa forma } \\
\text { me trazem frutos. }\end{array}$ \\
\hline \multirow[t]{2}{*}{$\begin{array}{l}\text { Natureza } \\
\text { metodológica }\end{array}$} & $\begin{array}{l}\text { Práticas em Ensino de Física vimos um pouco de experimentos de baixo custo (...). Mas } \\
\text { Quando você tem } 40 \text { alunos desinteressados, sem bancada, sem técnico, e aula de } 50 \\
\text { minutos, com um monte de aula, eu acabo não fazendo. Eu lembro que quando eu fazia } \\
\text { em Práticas, era trabalhoso, exige apetrecho. Você precisa ter em casa um } \\
\text { laboratoriozinho [sic]. }\end{array}$ \\
\hline & $\begin{array}{l}\text { Ciência e Cultura, era interessante, via a parte cultural da cidade, mas não consigo, } \\
\text { como Físico, falar que tem aplicabilidade na sala de aula, eu digo que não. Não via } \\
\text { muito sentido, era legal porque a gente passeava, mas em termos práticos de aula não foi } \\
\text { útil. Não fez sentido. }\end{array}$ \\
\hline $\begin{array}{l}\text { conhecimento } \\
\text { metodológico }\end{array}$ & $\begin{array}{l}\text { Teve uma professora que tentava mostrar como encaminhar o ensino, numa abordagem } \\
\text { bem construtivista, você tentar levar o aluno devagarzinho, depois produzir um material, } \\
\text { eu não lembro muito. No fim acabamos produzindo um material e mostramos como } \\
\text { colocaríamos esse material na sala de aula. }\end{array}$ \\
\hline
\end{tabular}

Planck

\begin{tabular}{|l|l|}
\hline $\begin{array}{l}\text { Natureza } \\
\text { metodológica }\end{array}$ & $\begin{array}{l}\text { Nas disciplinas da Licenciatura, quando o aluno tem alguma dúvida, ou quando o aluno } \\
\text { tem alguma coisa na cabeça, um questionamento, parece que os professores percebem. } \\
\text { Então o professor faz perguntas que provocam no sentido de uma reflexão. E nós } \\
\text { passamos a repensar nossos conceitos sobre Física ou algo do ensino. Não sei se é uma } \\
\text { característica da "física dura" e da educação - do ensino de física - não sei se é próprio } \\
\text { de cada curso, mas eu senti muito essa diferença. }\end{array}$ \\
\hline $\begin{array}{l}\text { Natureza } \\
\text { epistemológica }\end{array}$ & $\begin{array}{l}\text { O professor na disciplina de Gravitação abordou bastante a parte histórica da } \\
\text { Gravitação, ela foi umas das primeiras disciplinas que começou a abordar a questão } \\
\text { histórica. No Bacharelado não existe isso, a abordagem histórica da Física não acontece, } \\
\text { somente exercício. A Gravitação trouxe uma problemática do ponto de vista do cientista } \\
\text { da época. Então você começa a pensar como o cientista pensou no contexto da época } \\
\text { dele, você começa a pensar como que Newton pensava no contexto dele. Tinha toda a } \\
\text { parte de religião envolvida, de como o mundo funcionava naquela época, o que já tinha } \\
\text { sido descoberto ou o que não tinha. Essa disciplina começou a abrir o meu olhar e } \\
\text { descobri que falar de física vai muito além do exercício. Não é só sentar e ficar fazendo } \\
\text { exercício. Tem coisas, além disso, tem toda uma construção. Você começa a } \\
\text { compreender a Física como uma construção humana, ferramenta que vai se } \\
\text { desenvolvendo. }\end{array}$ \\
\hline
\end{tabular}




\begin{tabular}{|c|c|}
\hline \multicolumn{2}{|l|}{ Gauss } \\
\hline $\begin{array}{l}\text { Natureza } \\
\text { epistemológica }\end{array}$ & $\begin{array}{l}\text { Quando fiz Elementos e Estratégias para o Ensino de Física foi em um semestre que eu } \\
\text { quis trancar o curso pois não estava fazendo sentido. Então fiz essa disciplina e no } \\
\text { começo da disciplina o professor dá textos do Mario Bunge, do Rubem Alves, e sabe } \\
\text { quando você lembra-se de tudo aquilo que te fez prestar física no vestibular? Quando o } \\
\text { professor apresentou a epistemologia, discutimos trechos de textos que falam sobre } \\
\text { como é a Ciência, no caso da "ciência exata", como é o trabalho do cientista, que era o } \\
\text { tipo de coisa que eu sentia que estava perdendo. E essa disciplina ao propor o estudo de } \\
\text { algumas epistemologias e com as ideias do Thomas Kuhn, que era o propósito dessa } \\
\text { disciplina, me deu um "gás" novo no curso. }\end{array}$ \\
\hline $\begin{array}{l}\text { Natureza } \\
\text { metodológica/aleg } \\
\text { a falta de } \\
\text { conhecimento de } \\
\text { sala de aula no } \\
\text { ens. básico do } \\
\text { professor }\end{array}$ & $\begin{array}{l}\text { Práticas em Ensino de Física eu sentia muito que os discursos eram lindos, mas não } \\
\text { correspondia a nada da escola onde eu estava fazendo estágio. Eu sinto que o discurso } \\
\text { idealizado é tão bonito academicamente, mas chega num ponto que ele não corresponde } \\
\text { a nada da realidade escolar e fica simplesmente teórico. Isso me incomodou } \\
\text { profundamente. Vou dar um exemplo que mais me incomodou. Teve uma aula onde o } \\
\text { texto prévio, não era do Paulo Freire, foi sobre o Paulo Freire. E foi um texto do } \\
\text { Delizoicov, explicava o pensamento do Paulo Freire, o que era a educação } \\
\text { problematizadora. E o engraçado que o Paulo Freire que prega um discurso de } \\
\text { dialogicidade, de você ao mesmo tempo ser um educador, ser um educando, e essa aula } \\
\text { foi um monólogo da Professora. E pra mim, uma aula onde é um monólogo sobre o } \\
\text { Paulo Freire, é uma aula incoerente. Uma das coisas que ela propôs nos estágios de } \\
\text { Práticas foi a montagem de uma sequência didática baseada nos Três Momentos } \\
\text { Pedagógicos (...). O momento da problematização acontecia, mas depois surgiam os } \\
\text { entraves que a teoria não previa, como esse de ter que improvisar, foi algo que muitos } \\
\text { grupos não conseguiram fazer direito. O meu grupo, por exemplo, tentou fazer uma } \\
\text { atividade experimental, fazer experimentos como parte da problematização. Não deu } \\
\text { certo, a gente não sabia o que estava fazendo. Hoje eu vejo que o erro aconteceu porque } \\
\text { não conhecemos nosso público. Em uma disciplina com estágio eu acho muito ruim } \\
\text { porque o aluno precisa conhecer o público antes de intervir. As aulas não deram certo. }\end{array}$ \\
\hline & $\begin{array}{l}\text { Ciência e Cultura, eu tenho amigos que fazem outra licenciatura e as horas de } \\
\text { Atividades Culturais Científicas e Acadêmicas que eles fazem, eles de fato fazem. Eles } \\
\text { precisam provar que visitaram museus, visitaram exposições, que eles realmente fizeram } \\
\text { a atividade e são muitas horas. E em Ciência e Cultura eu sinto que existe uma } \\
\text { maquiagem em torno dessas horas. Então eu sinto que meu contato na graduação com } \\
\text { espaços não formais, que era a proposta, foi muito aquém do que eu esperava. Só que a } \\
\text { disciplina, apesar disso, foi boa. Quando ele fala de Bourdieu, eu acho incrível. A } \\
\text { primeira vez que eu achei interessante a ideia do capital cultural, acho que ele falou } \\
\text { muito bem e em todo lugar que a gente ia, eu conseguia fazer correlações. }\end{array}$ \\
\hline
\end{tabular}

Mayer

Dimensão epistemológica e metodológica
Na disciplina de Prática em Ensino de Física, tivemos que fazer uns planos de aula. Tivemos uma aula em que utilizamos baralho para falar de Física de Partícula e a professora aplicou primeiro em nós, isso é bacana. Primeiro a professora faz com a gente, depois nós podemos usar com nossos alunos. E a professora falou depois que você pode aplicar nas suas próprias aulas. Pelo menos pra mim faz diferença, você ver, fazer e depois você aplicar. Para você ter melhor noção. E fez isso também com uma atividade de refração que ela pegou uma pedra que duplica a imagem e era para a gente refletir sobre aquele fenômeno de Óptica, que era a birrefringência, mas só depois de refletirmos e discutirmos é que a professora explicou. É uma coisa que faz diferença. Em relação ao plano de aula, acho que fazer o plano de aula é muito difícil, eu tenho muita dificuldade e quando você vai dar aula você tem um conteúdo inteiro para dar, toda semana você tem que estar na escola, duas vezes por semana, dando aula pra mais de uma turma e você tem que planejar cada uma daquelas aulas, dá trabalho. Se você não 
tiver tudo pronto num banco de dados, aula de Termodinâmica, aula de Cinemática, etc., talvez isso seja complicado. Se você é um professor de primeira viagem, sem um banco de dados seus com planos de aula, você geralmente vai dando aulas iguais a que você teve.

\section{3 - Formação Pedagógica Geral}

Quadro 15 - Falas sobre disciplinas da Formação Pedagógica Geral

\begin{tabular}{|l|l|}
\hline \multicolumn{2}{|l|}{ Herschel } \\
\hline $\begin{array}{l}\text { Outros alunos } \\
\text { da Licenciatura } \\
\text { tem preconceito } \\
\text { dessas } \\
\text { disciplinas }\end{array}$ & $\begin{array}{l}\text { No geral o pessoal não gosta muito dos cursos da Faculdade de Educação, para mim eles } \\
\text { ajudaram, mas eu acho que existe certo preconceito em quem faz Licenciatura em } \\
\text { rada, às vezes eu acho que é arrogância. Aço que, como na Ciência criticamos o senso } \\
\text { comum, também acho que existe uma resistência de ver a Pedagogia e Educação como } \\
\text { uma área específica de conhecimento, então essas pessoas tratam muitas questões de } \\
\text { Educação por senso comum. E isso eu ouço de Doutores em outras áreas, e nas escolas. } \\
\text { Isso é preconceito. Eles falam que é tudo besteira o que tem na Pedagogia. Entretanto, eu } \\
\text { sempre me dei bem concurso porque eu sempre li todos os textos daqui da licenciatura. }\end{array}$ \\
\hline & $\begin{array}{l}\text { Estrutura e Funcionamento da Educação, o professor me deu uma visão da educação que } \\
\text { eu nunca tinha visto e eu fiquei apaixonada pela educação. }\end{array}$ \\
\hline
\end{tabular}

Heisenberg

Outros alunos

da Lic. têm desprezo dessas disciplinas

Eu gostei bastante das disciplinas da educação. No geral, o pessoal desprezava as disciplinas da educação, mas eu gostava bastante. Tanto é que na disciplina de Práticas do Ensino eu tive a chance de fazer um estágio no (...). É um programa para ensinar para os funcionários da USP que não tiveram chance. Então eu dava aula de física para os últimos anos do fundamental no laboratório da faculdade de educação. Então para mim foi muito bom, pois esse projeto tinha o acompanhamento de uma outra professora que estava organizando. Era um paraíso pois eu tinha acesso ao laboratório, às experiências. $\mathrm{Eu}$ podia fazer praticamente qualquer experiência que eu quisesse e tinha o acompanhamento da professora. Eu montava uma aula e perguntava para ela se estava bom. Eu tinha todos os instrumentos que precisava e um apoio teórico por trás disso. Para mim foi bom. De qualquer forma eu tive essa chance de ter um laboratório na faculdade disponível e um apoio teórico por trás. Então foi um momento bem rico. (...) Ela usava bastante vídeo. Eu me lembro de um livro que ela que são os passos para você analisar uma aula, verificar o que é uma aula boa. Esse livro foi um dos meus referenciais. Eu seguia na hora de montar uma aula. Depois de um tempo você vai vendo que tem uma ou outra coisa que precisa modificar adaptar para a escola.

Didática eu gostei bastante, a professora respondia tudo, sem frescura. Acredito que o professor influencia muito na hora de você fazer a disciplina mais que o conteúdo. Independente do conteúdo o professor pode tornar a aula motivante.

Maxwell

Outros alunos da Lic. têm desprezo por essas disciplinas.
Quando vim para a Licenciatura eu já queria ser professor e eu percebia em alguns colegas, na disciplina da Educação certo desprezo por elas, mesmo em colegas da Licenciatura. E para mim, o que era discutido nas disciplinas era muito importante, eu discutia isso com eles, eu falava que não dava para ter essa postura: você pode não gostar de um texto, ou não gostar de um professor, mas a discussão sobre didática, por exemplo, é super fundamental (...) As pessoas achavam que para ser professor não 


\begin{tabular}{|l|l|}
\hline & $\begin{array}{l}\text { precisava daquilo que era discutido nas disciplinas da Faculdade de Educação. Eu } \\
\text { pensava que isso é por que aquele aluno da graduação não tinha ido para a sala de aula. } \\
\text { Por isso eu falo que essa experiência que eu tive de } 6 \text { meses de "hardcore" na escola, } \\
\text { com um grupo preocupado com a educação, com uma equipe que me adicionava e que } \\
\text { se preocupavam comigo, por eu ser novo e sabiam que eu não era professor, eles me } \\
\text { ajudavam na prova, nas atividades. Comecei o primeiro semestre super tradicional e } \\
\text { terminei de outra maneira. Eu fui incorporando naquele semestre as coisas que eu estava } \\
\text { discutindo com os colegas e isso fez a diferença na minha formação. Mas eu não via isso } \\
\text { nos colegas na licenciatura. }\end{array}$ \\
\hline $\begin{array}{l}\text { POEB já foi fundamental, por como eu já tinha vivido e estava vivendo essa experiência } \\
\text { na escola, eu comecei a entender como era formada a escola. Nesse sentido, essas } \\
\text { disciplinas fizeram muito sentido, Psicologia da educação também. }\end{array}$ \\
\hline $\begin{array}{l}\text { Em Psicologia da Educação nós vimos Piaget, Wallon, um pouco de Vygotsky, um } \\
\text { pouco de Freud. Acho que um pouco de tudo e é essa função da disciplina, não é } \\
\text { aprofundar, é ser mais geral e se a pessoa quiser, ela consegue aprofundar. }\end{array}$ \\
\hline
\end{tabular}

\section{Fermi}

Entender como o aluno pensa, a gente entende, mas sinceramente, em minha opinião, tinha muita coisa que na prática não se enquadram direito. Muita matéria que eu fiz na educação, por exemplo. Na Faculdade de Educação tinham umas matérias gerais que não são nenhuma da Física, lá você faz um monte de matéria, umas seis ou sete, de vários cursos tais como POEB, Psicologia da Educação, mas você não sente respaldo, você tem que fazer porque tem que fazer, mas não dão respaldo para a sala de aula. Eram teóricas demais, você lia alguns autores e discutia o que eles pensam, mas não sei se esses autores eram do estrangeiro e tinham alunos ideais, educados, formados. Mas não condiz com a realidade do Brasil, que são alunos que não tem bagagem, não tem pré-requisito, que você tem que montar o pré-requisito com o aluno. Mas como eu já estava dando aula durante as aulas na Faculdade de Educação, elas não se adequam a realidade da sala de aula. Era muito distante o que era tratado lá do que eu vivia.

A visão que eu tenho, alguns docentes da Faculdade de Educação estão há muito tempo afastados da sala de aula, de uma escola pública, por exemplo. Nos últimos 10 anos a escola mudou muito, para entender como é uma sala de aula de escola pública tem que estar ha pelo menos há um ano, todo dia lá vendo. E a impressão que davam aquelas aulas, é que eram docentes, as aulas eram bem-feitas, eles eram bons na área deles, mas não refletia muito o quê é uma sala de aula. Era teórico demais, não dava solução.

\section{Planck}

Mas na Faculdade de Educação também tiveram umas boas disciplinas que me marcaram bastante - POEB e Metodologia do Ensino de Física. Essas duas me marcaram bastante porque elas traziam abordagens bem diferentes sobre o ensino. Como eu tinha uma visão de ensino muito tradicional, elas já conseguiram desconstruir muita coisa dessa visão (...). Os professores nessas disciplinas levantavam questões dentro da aula, que exigia reflexão. E ficamos nos questionando e isso motivava a buscar mais conhecimento (...). Então deixei o Bacharelado por desilusão com o curso, eu gostava muito de física, não queria desistir, queria dar uma segunda chance. Mas no bacharelado não deu certo, então fui para o ensino, para a Licenciatura para ver se o foco do curso mudava. E mudou totalmente.

Gauss

POEB É uma disciplina útil. Concordo. Mas mal dada. E eu acho que ela está no 


\begin{tabular}{|l|l|}
\hline & $\begin{array}{l}\text { momento errado, quando eu tive no segundo semestre, era muito imaturo para entender } \\
\text { tudo aquilo que era dado e eu acho que ela é mais útil no fim do curso. Porque você } \\
\text { estuda a legislação, você estuda teorias de currículo? Acho que tem que ser mais para os } \\
\text { últimos semestres, porque muita gente acha que por ela ser uma disciplina muito } \\
\text { informativa, as pessoas se afastam pelo menos as pessoas da Física, não sei de outras } \\
\text { licenciaturas. Eu me senti muito afastado, e depois que eu me formei, foi incrível, um } \\
\text { dia eu sentei e fui ler a LDB, por iniciativa própria. }\end{array}$ \\
\hline & $\begin{array}{l}\text { Didática eu fiz com uma professora muito boa que baseava as aulas em textos, como } \\
\text { todos os professores da educação, mas ela é uma das poucas professoras que eu digo que } \\
\text { sabe o que está fazendo. Porque ela não pulou de paraquedas na academia. Ela foi } \\
\text { professora da educação básica durante muitos anos. Então esse foi um diferencial } \\
\text { tremendo. }\end{array}$ \\
\hline
\end{tabular}

\begin{tabular}{|l|l|}
\hline Mayer & $\begin{array}{l}\text { POEB acho que quando escolhemos ser professor funciona assim, eu serei contratada } \\
\text { por uma escola, vou dar aula e acabou. Pois o que eu tenho com a escola é um contrato } \\
\text { e um compromisso de dar aulas. Mas em POEB, por exemplo, você acaba conhecendo } \\
\text { todas as esferas políticas e administrativas do que acontece dentro da escola. Como } \\
\text { funciona toda organização, como a escola é planejada, o que tem por traz do } \\
\text { financiamento da escola, como o projeto político é planejado, como isso interfere nos } \\
\text { aspectos do dia a dia, como a escola enxerga o conselho participativo, se ela adota como } \\
\text { ela adota... todas essas coisas que na disciplina ficou mais claro. Outra coisa que eu } \\
\text { aprendi em POEB é sobre a escola democrática, sempre ouvia falar, mas não sabia seu } \\
\text { funcionamento. Então, depois da disciplina, eu tive maior noção de como funciona de } \\
\text { fato e o que significa uma escola democrática. No próprio estágio de POEB pude fazer } \\
\text { em uma escola de ensino fundamental e este estágio me possibilitou perceber a visão dos } \\
\text { professores, da direção, dos alunos, conhecer o diretor e a coordenadora, a presença } \\
\text { deles e sua relação com todos, professores, alunos e funcionários. Que nessa escola a } \\
\text { relação é diferente de onde faço estágio da disciplina de Práticas, então consigo } \\
\text { comparar as duas escolas, pois elas funcionam de maneiras diferentes. }\end{array}$ \\
\hline
\end{tabular}

\subsubsection{As dimensões descritivas}

As dimensões de análise forneceram a base para construir a análise descritiva dos dados. Esse processo de análise descritiva, entretanto, demandou um novo reagrupamento das ideias contidas nas dimensões de análise, para fins de melhor organização de ideias. Esse reagrupamento serviu para facilitar a descrição do processo de acordo com os temas emergentes das falas e as tendências desses temas. Vamos denominar essas novas dimensões por Dimensões Descritivas. Elas são a decodificação dos dados brutos contido nas falas que anteriormente foram reunidos em dimensões de análise: 
Quadro 16 - Dimensões descritivas que se desprenderam das dimensões de análise

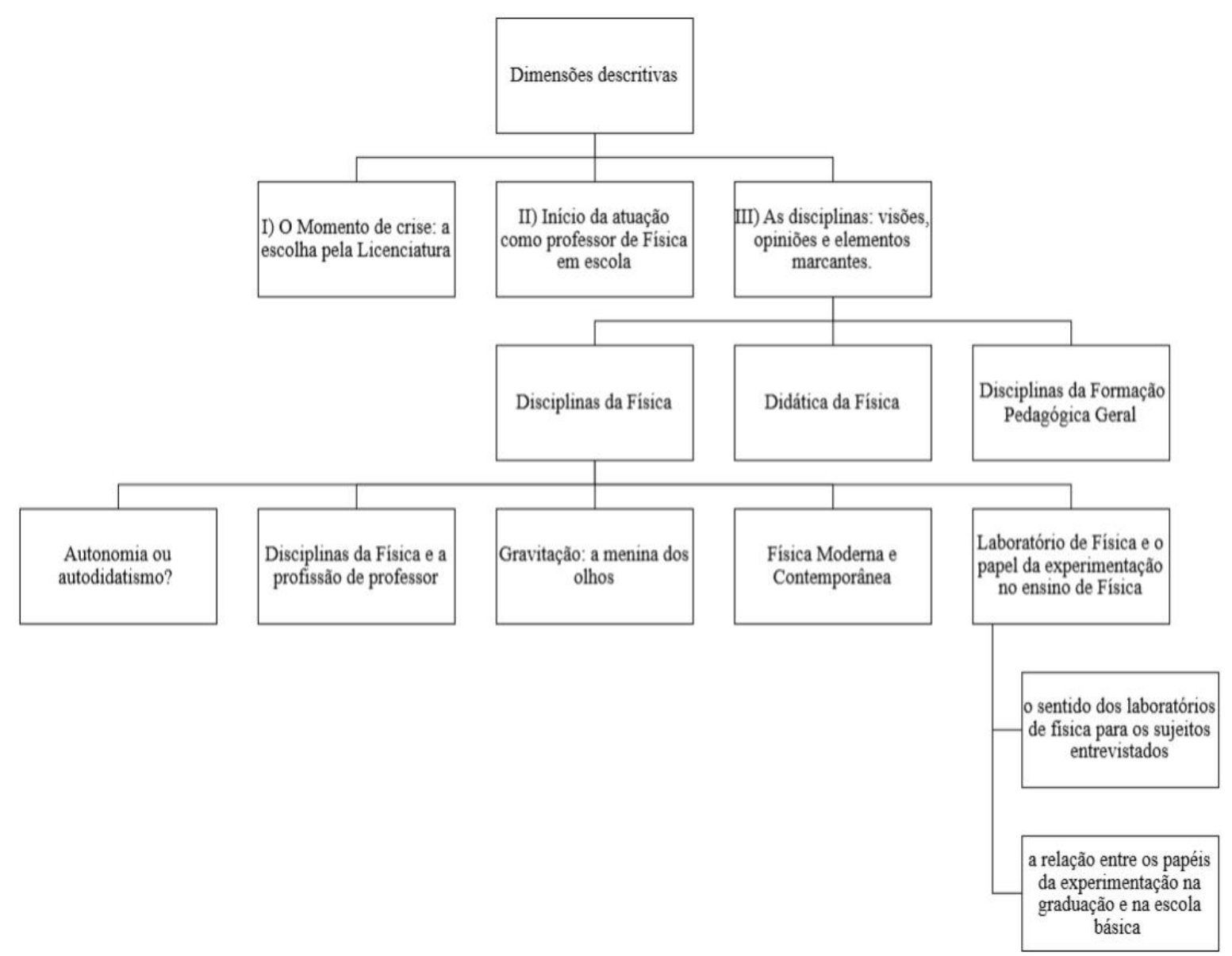

O leitor pode encarar essa nova divisão ou reagrupamento segundo certa ordem cronológica correspondente às fases do processo de formação inicial. É como se a cada fase (início, meio e fim) fosse atribuído um marco estabelecido com base nas próprias informações trazidas pelas entrevistas. O marco que pode ser estabelecido para o início do processo de formação inicial para os nossos entrevistados são as motivações que levaram à escolha da licenciatura em física. O marco do fim do processo da formação inicial compreende a descrição dos conflitos de início da carreira. O meio do processo, que corresponde à formação inicial propriamente dita, tem como marco as disciplinas. A descrição gira em torno dos elementos marcantes dessas fases.

Sobre o início do processo formativo que compreendemos como sendo a escolha da licenciatura, os depoimentos dos nossos sujeitos revelaram os motivos pelos quais escolheram a Licenciatura em Física. Um dado curioso surgiu dessas falas: dos oito sujeitos entrevistados, seis vieram de curso de Bacharelado (em Física ou de área correlata). Esse fato não foi intencional. A informação de que os sujeitos vieram evadidos do Bacharel foi revelada somente no momento da entrevista e essas falas apontam que os sujeitos vivenciaram graus de 
desapontamento em sua primeira graduação. Aliado a essa experiência, os sujeitos entrevistados tiveram a oportunidade de ter algum contato com o ensino - seja dando aula em escola, seja em disciplinas da Faculdade de Educação ou através do convívio social - e isso colaborou para fomentar nos nossos entrevistados a expectativa de que a Licenciatura em Física fosse capaz de oferecer oportunidades diferentes das do Bacharelado e até mais positivas, de acordo com nossos sujeitos de pesquisa. Para ajudar na compreensão do fenômeno descrito por nossos informantes, recorremos aos estudos de Tinto (1987) sobre evasão e retenção em cursos de universidades americanas e a ideia proposta por esse autor de que cursos que promovem boas práticas institucionais são capazes de proporcionar a retenção eficaz dos seus alunos.

No outro extremo do processo formativo, está o início da carreira profissional. Esse início da carreira de um professor, geralmente, ocorre através da atuação em escolas do ensino básico. Pesquisas apontam que essa fase é um momento crucial para a carreira profissional, pois nesse momento o professor vive tensões e conflitos. Porém, para superar essas adversidades, o recém-formado elabora estratégias que muitas vezes estão ancoradas em crenças que prevalecem apesar de todo o processo da formação inicial. Nesse sentido, nossos sujeitos revelaram através das entrevistas algumas das principais preocupações e conflitos vividos por eles. Para ajudar na categorização destes sentimentos, os instrumentos utilizados foram os estudos de Fuller ${ }^{8}$ (1975 apud BEJARANO; \& CARVALHO, 2004) no qual o autor propõe um modelo de 3 fases para desenvolvimento do professor e de Beach \& Pearson ${ }^{9}$ (1998 apud BEJARANO; \& CARVALHO, 2004) que caracterizaram 4 tipos principais de conflitos que podem surgir no período que compreende o início da profissionalização.

O período compreendido entre a escolha pela Licenciatura em Física e o início da atuação profissional está a formação inicial. Nessa fase os alunos têm a rotina das disciplinas da Física, da Didática da Física e da Formação Pedagógica Geral. Esses três blocos de disciplinas formam o coração da formação. Com o intuito de compreender quais foram os elementos marcantes da formação inicial dos nossos sujeitos, buscamos ouvir suas críticas às marcas deixadas pelas disciplinas da grade da Licenciatura. Essas informações deram origem a novas subcategorias: Disciplinas da Física, Didática da Física e Formação Pedagógica. Além dessa divisão, buscamos elencar as falas que remetem às informações que desejávamos

${ }^{8}$ FULLER, F.F. Concerns of teachers: A developmental conceptualization. American Educational Research Journal, V. 6, N. 2, P. 207-226, 1969.

${ }^{9}$ BEACH, R.; PEARSON, D. Changes in preservice teachers' perceptions of conflicts and tensions. Teaching and Teacher Education, v. 14, n. 3, p. 337-351, 1998. 
através de uma ordem cronológica, tal como foi feito nas categorias Momento de Crise: a escolha pela Licenciatura e Início da atuação como professor de Física em escola. Isso significa que, na categoria Disciplinas da Física, as unidades de sentido estão ordenadas na seguinte configuração: a fala de Herschel aparece primeiro, depois a de Heisenberg, seguida por Maxwell, Feynman, Fermi, depois Planck, Gauss e finalmente Mayer. O mesmo foi feito na categoria de análise da Didática da Física e da Formação Pedagógica Geral. Isso foi feito com o objetivo de ser possível diferenciar as opiniões e elementos marcantes nos sujeitos de acordo com as grades da Licenciatura. Posterior à divisão das falas proposta acima se iniciou o processo de análise e comparação desses depoimentos.

Desse processo, depreenderam-se outras novas subcategorias. Ao analisar as falas dos nossos informantes sobre as disciplinas da Física, elas forneceram cinco novas categorias. A primeira delas aborda a questão da autonomia. Durante a produção de dados, essa dimensão de análise estava separada, como uma dimensão isolada, mas durante o processo de análise foi possível compreender que essa dimensão se relaciona com as disciplina do conteúdo a ensinar da Física. Por esse motivo, resolvemos incorporar essa dimensão de análise dentro da dimensão de descrição sobre as disciplinas do conteúdo a ensinar. Sobre o sentido dado pelos sujeitos à "autonomia”, isso parece estar mais próximo ao autodidatismo. A segunda categoria revela alguns indícios de como aspectos profissionais são discutidos dentro do escopo das disciplinas da Física, já que essa é uma proposta que o Projeto Pedagógico de 1993 preconizava. As falas sugerem que alguns professores procuram seguir a proposta do Projeto. No entanto, parece que a compreensão por parte de professores e alunos do significado do que seja levar aspectos da profissão para as disciplinas não esteja adequado. Na categoria Gravitação, a menina dos olhos, os entrevistados parecem revelar que as abordagens fenomenológica, histórica e filosófica da Ciência e da Física são valorizadas e alguns sujeitos parecem indicar um pedido (implícito) de que essas abordagens sejam trabalhadas também em outras disciplinas. Já as falas dos sujeitos sobre os Laboratórios de Física revelam críticas negativas sobre essas disciplinas. Embora os entrevistados pareçam compreender que as atividades experimentais e práticas do laboratório são importantes, principalmente como uma ferramenta importante no ensino básico, as falas parecem indicar que os laboratório de física não propiciaram o desenvolvimento dessa cultura científica. Isso sugere que a compreensão de alguns sujeitos sobre o papel da experimentação no ensino de Física parece ter sido desenvolvida em outros espaços da formação (atuando como monitores em projetos de divulgação científica) ou em outras disciplinas do curso (Prática em Ensino de Física). 
Para analisar as falas dos sujeitos sobre as disciplinas da Didática da Física, foi utilizado um instrumento teórico que identifica três dimensões de conhecimento que essas disciplinas devem desenvolver nos futuros professores: a dimensão epistemológica, a dimensão cognitiva e a dimensão metodológica. Dessas três dimensões propostas, as dimensões metodológicas e epistemológicas foram as mais aludidas nas falas dos nossos sujeitos. Essas alusões podem sugerir que as disciplinas que desenvolvem esses aspectos (Gravitação e Práticas em Ensino de Física, por exemplos) sejam apreciadas pelos entrevistados. 


\section{Análise Descritiva}

No Capítulo anterior, descrevemos como os dados foram produzidos e organizados. Com auxílio da Metodologia de Análise do Conteúdo, os temas recorrentes contidos nas entrevistas e que se relacionavam com as questões e objetivos desta pesquisa foram organizados. Da organização dos recortes das entrevistas em temas, foi possível inferir as Dimensões de Análise, que contém ainda os dados brutos. Essas dimensões, por sua vez, serviram como base para a próxima etapa que é a descrição das informações contidas nesses dados brutos, isto é, do olhar dos egressos sobre o processo formativo investigado. Essas informações constituem os dados propriamente ditos e para obtê-los é necessário um processo de decodificação - ou lapidação -. Através dessa decodificação é que esperamos constatar como foi o processo formativo para nossos sujeitos, os elementos marcantes, suas as opiniões e visões sobre esse processo. A Análise Descritiva, como o nome indica, consiste em descrever as principais tendências existentes nos dados e observar informações explícitas e implícitas. Essa descrição das informações será balizada, quando possível, com algum aporte teórico que ajude a aprofundar a análise.

\subsection{O Momento de crise: a escolha pela Licenciatura}

No total, oito sujeitos concederam um depoimento sobre seus processos formativos. Desse número de entrevistados, apenas dois ingressaram na Licenciatura sem ter passado por uma experiência prévia no Bacharelado em Física ou em curso correlato a Física. Todos os outros informantes experimentaram, antes da escolha pela Licenciatura, uma trajetória no Bacharelado que foi interrompida. Focaremos a análise nos motivos que alicerçaram a escolha pela Licenciatura em Física dos sujeitos que vieram de outra graduação: Herschel, Heisenberg, Fermi, Maxwell, Planck e Mayer.

Nas falas dos entrevistados Herschel, Heisenberg, Maxwell, Planck e Mayer chama atenção o sentimento de "crise", "desilusão" ou "chateação" como estopim para a mudança de curso, um sentimento recorrente nesses entrevistados e que parece ter como alavanca, especificamente, a experiência anterior no Bacharelado em Física. Herschel, Planck e Mayer sinalizam que a alavanca, para esses sujeitos, foi a insatisfação com as aulas, as propostas didáticas ou objetivos do curso. Por exemplo, revela Planck: 
Eu entrei no Bacharelado, fiz dois anos, e mudei para a licenciatura. Me sentia muito mal no Bacharelado. Não suportava mais pegar o livro e fazer trinta exercícios. Me perguntava o motivo de estar fazendo esse exercício repetidas vezes. Acontecia nas aulas do Bacharelado de não entender o professor ou a professora, mas se eu perguntasse, eles falavam "como assim, você não entendeu, não é simples?" (...) Então deixei o Bacharelado por desilusão com o curso, eu gostava muito de física, não queria desistir, queria dar uma segunda chance. Mas no bacharelado não deu certo, então fui para o ensino, para a Licenciatura para ver se o foco do curso mudava. (Planck)

Para Heisenberg, a alavanca foi a dificuldade que ele enfrentava nas disciplinas em relação ao pré-requisito do curso. Para esse sujeito, o fato de ter vindo de escola pública, o faz supor que sua base matemática e da própria Física eram deficitárias, por isso decide migrar para um curso em que, de acordo com a visão dele, não houvesse tantas exigências quanto ao formalismo matemático:

Diferente dos meus colegas eu vim de uma escola pública. Então, apesar de ter feito o curso técnico, eu tinha muita dificuldade em matemática (...) para passar nessas disciplinas [do Bacharelado] eu levei bastante tempo. Aqui foi a primeira vez que repeti na minha vida (...). Para ser sincero, eu não queria dar aula. Quando entrei eu queria ser Astrônomo, na época para ser Astrônomo você fazia Geofísica, Geologia ou Física. Só que eu estava tendo dificuldade para seguir o plano, e era por causa da matemática. Fui sendo realista e me perguntando qual curso que eu poderia fazer, já que tinha dificuldade em algumas disciplinas. (Heisenberg).

A fala de Maxwell, tal como a de Fermi (no capítulo anterior), em contrapartida, revela que as insatisfações estavam alicerçadas na escassa perspectiva de atuação profissional dos Bacharéis:

Adoro ciência, só que ao fazer Iniciação [Científica] e ir ficando mais velho no curso, comecei a entrar em contato com o mercado de trabalho e o mundo acadêmico, então pensei que não era bem aquilo que eu queria. E comecei entrar em crise sobre o curso. (Maxwell)

O Fermi revela ainda que "queria ter uma carta na manga", ou seja, queria o diploma da Licenciatura para, caso fosse necessário, pudesse atuar como professor em escola básica. Uma visão da Licenciatura em Física como um curso extra. Apesar de terem vieses diferentes, todos os motivos para o desapontamento com o Bacharelado em Física parecem convergir para uma mesma origem. Tal origem pode ser entendida analisando como é a estrutura das disciplinas no Bacharelado em Física. De acordo com Lima Júnior (2013), neste curso ocorre o predomínio de disciplinas de cunho puramente abstrato e com denso formalismo matemático. Essas disciplinas também apresentam certa invariabilidade em termos de estratégias de ensino e avaliação que são praticamente as mesmas entre as disciplinas introdutórias e finais dos cursos de bacharelado (LIMA JÚNIOR, 2013). Todas as disciplinas envolvem aulas expositivas, deduções na lousa, pouca interação em sala de aula, muito estudo em casa, resolução de listas de exercícios e provas individuais. Ainda conforme Lima Júnior 
(2013), geralmente não ocorrem discussões fenomenológicas sobre a Física, muito menos são solicitadas outras atividades por parte dos professores. $\mathrm{O}$ autor concluiu, portanto que isso exigiria uma rotina que para muitos alunos pode ser maçante. Essa poderia ser uma explicação para o desânimo sentido pelos nossos sujeitos em relação ao curso de Bacharel:

As aulas estavam ruins (...). Em algumas disciplinas do Bacharelado, dependendo do professor, ficava uma coisa meio parecida, todas as aulas eram iguais. (Mayer)

Fora isso, cursos que formam bacharéis, em específico de Física, culturalmente valorizam o desempenho ostensivo do alunado e o individualismo, o que exige uma rotina de estudos severa (LIMA JUNIOR, 2013). Se essa rotina for a causa do desconforto com o Bacharelado sentido pelos nossos sujeitos, isso ajuda na compreensão do motivo pelo qual alguns dos nossos entrevistados passaram a ver na Licenciatura em Física um recurso para completar a graduação: seja por julgarem que o curso seja menos exigente (o que não necessariamente seja verdade) ou que as discussões sobre a física fossem mais prazerosas.

As diferentes circunstâncias que proporcionam o contato com o ensino, através da sala de aula na escola como professor, em projetos de divulgação científica, através do convívio social com alunos da Licenciatura em Física ou por meio de eventos de divulgação da Licenciatura também colaboraram com a ideia de que a Licenciatura em Física, através das disciplinas, seria capaz proporcionar aos sujeitos aquilo que o curso de bacharel não conseguiu. Como apontam Herschel, Heisenberg e Mayer:

Fiquei em crise muito tempo, mas não conseguia deixar à Física. Fiz um curso de introdução à astronomia, tinha algo que eu buscava e não encontrava no curso. Uma satisfação. Então em um curso da Licenciatura, na Faculdade de Educação, o professor foi muito importante. Ele era muito apaixonado pelo ensino e pela educação. Foi no curso de Estrutura e Funcionamento da Educação, e essa disciplina com esse professor me deu uma visão da educação que eu nunca tinha pensado, foi daí que eu fiquei apaixonada pela educação. (Herschel)

Em 1992 trabalhei em uma exposição de Física como monitor e percebi ali que sabia algo. E as pessoas gostavam da minha explicação. Então, se tinha dificuldade em algumas matérias, mas ainda gostava de Física e gostava de ensinar, por que não? (Heisenberg)

Eu já tinha alguns amigos na Licenciatura que me contavam sobre as disciplinas do curso. Então comecei a descobrir outras possibilidades de atuação, além de ser professor: que os alunos da Licenciatura faziam Mestrado em Ensino, em História da Ciência, por exemplo. E fui descobrindo coisas novas sobre a Licenciatura vindo à Semana da Licenciatura. (Mayer)

De fato, os entrevistados demonstram um sentimento revigorado com as perspectivas que a Licenciatura parece oferecer. E esse sentimento parece manter-se depois que ingressam na Licenciatura. Podemos compreender isso considerando que na Licenciatura em Física, o aluno encontra uma abordagem mais conceitual e fenomenológica da Física, pois o intuito das 
aulas é de dar aos alunos uma formação menos distante da sala de aula da educação básica de acordo com o Projeto Político Pedagógico da Licenciatura. De acordo com as propostas do documento que direciona a Licenciatura em Física pelo IFUSP, as estratégias de ensino, os propósitos das disciplinas e os métodos de avaliação também deveriam ser mais diversos, isso poderia contribuir para que o ambiente da própria sala de aula se torne mais integrador e favorável à colaboração. É o que a fala de Planck parece revelar:

E quando eu mudei para a Licenciatura, a parte do início do curso eu já tinha tido no bacharelado, então foquei nas disciplinas de educação, principalmente as que são do IF. E eu gostei muito! Mas na Faculdade de Educação também tiveram umas boas disciplinas que me marcaram bastante - POEB e Metodologia do Ensino de Física. Essas duas me marcaram bastante porque elas traziam abordagens bem diferentes sobre o ensino. Como eu tinha uma visão de ensino muito tradicional, elas já conseguiram desconstruir muita coisa dessa visão [...] Os professores nessas disciplinas levantavam questões dentro da aula, que exigia reflexão. E ficamos nos questionando e isso motivava a buscar mais conhecimento. (Planck)

Alguns resultados de um estudo realizado por Tinto (1987), cujo objetivo era o de compreender a evasão e retenção em cursos de algumas universidades Americanas, pode colaborar com a compreensão sobre esse dado. Através de seu estudo, o autor conseguiu definir algumas características sociais, individuais e institucionais que podem contribuir com a evasão ou com a retenção dos alunos nos cursos. O modelo proposto por Tinto (1987) sustenta a ideia de que um sujeito, antes de ingressar em um curso superior, possui alguns atributos que dependem da história da família, das habilidades individuais e da escolarização. Ao ingressar na graduação, esse sujeito estabelece intenções e comprometimentos que dependem daqueles atributos anteriores. Se as experiências institucionais (sistema acadêmico e sistema social) forem capazes de promover a integração social e acadêmica do aluno, promovem a atualização ou sustentação das intenções e comprometimentos anteriores do aluno. O resultado disso é a permanência desse aluno na graduação. Por outro lado, se as experiências institucionais não forem positivas, capazes de promover a integração acadêmica e social, o aluno acaba evadindo do curso. Para ter sucesso na retenção dos alunos, em oposição à evasão, a instituição deve promover o que o autor chama de boas práticas. Tinto (1987) observou os princípios que alicerçam tais práticas e conseguiu tipificá-las em 3 categorias:

a) Comprometimento com bem estar do aluno, acima de qualquer outro objetivo institucional (acima até da produção científica);

b) Comprometimento com a educação de todos, não deixando a educação de seus alunos ao acaso ou predominantemente sob responsabilidade dos próprios alunos; 
c) Comprometimento com as comunidades acadêmicas e sociais, que significa a valorização da vida comunitária (social e intelectual) dentro e fora de sala de aula.

Isso nos permite descrever o seguinte quadro: parece que a Licenciatura em questão foi capaz de proporcionar a retenção eficaz dos sujeitos entrevistados, possivelmente através de boas práticas institucionais. Com isso, as intenções e comprometimento que os alunos tinham no Bacharelado, ao ingressar na Licenciatura se transformam e se renovam em outras intenções e comprometimentos que, para os que ingressam na Licenciatura em Física são de aprender a ensinar Física e tornar-se Professor de Física.

Um dado curioso é que a maioria das falas sugere que a Licenciatura em Física só tenha se tornado uma opção depois do contato do sujeito com o ensino, ou seja, até certo momento da graduação, os entrevistados parecem não compreender ou não perceber o significado de um curso para formar professores. As concepções configuram-se como ancoradas no senso comum:

Eu pensava que o Bacharelado em Física era hierarquicamente superior a Licenciatura de modo que, me formando no Bacharelado eu seria uma escolha melhor. Ser pesquisador de física pura, trabalhar com física teórica, experimental, enfim, é muito melhor do que você pensar em como ensinar física. Parece que não se passava pela minha cabeça que você tem que pensar na Física também para ensinar, além de pensar em como ensinar. [...] No meio do ano passado eu comecei a repensar isso. (Mayer)

Mas isso parece mudar depois do contato em algum grau com a profissão de professor e/ou com o ensino (não mais na figura de aluno). Depois dessas experiências os sujeitos começam a atribuir à Licenciatura em Física outros significados e importância:

Antes de ingressar na Licenciatura, enquanto estava no Bacharelado eu comecei a
dar aula em uma escola pública, assim percebi que na prática a pessoa que tem a
visão de Bacharelado, que nunca entrou numa sala de aula, acha que a aula tem que
ser de um jeito. O bacharel tem aquela visão... por exemplo, um amigo Físico falava
que a aula ideal tinha que ser igual àquela aula de cursinho pré-vestibular, ele acha
que aquilo é uma aula ideal, com continha e que todos entendem, e essa é uma visão
de um bacharel, não é a visão do aluno do ensino médio. Mas eu senti isso em sala
de aula, porque se você quer fazer os alunos aprenderem alguma coisa, então tem
que ter outras abordagens. Abordagens que sendo Bacharel em Física,não te dá
respaldo. A escolha pela Licenciatura me ajudou nesse sentido. (Fermi)

A fala do Fermi resume bem qual a visão de uma parte dos entrevistados antes e depois da experiência com o ensino. Para alguns dos entrevistados, as falas sugerem que o processo que colaborou com a mudança de visão foi como a de Fermi, através da experiência concreta em sala de aula de escola. Para outros sujeitos, as falas indicam que aquele processo foi potencializado por outras experiências. Por exemplo, para Herschel e Planck a experiência mais significativa que parece ter possibilitado a mudança de visão sobre a Licenciatura em Física foram as disciplinas da Faculdade de Educação e da Didática da Física. Já para 
Heisenberg, foi em um trabalho como monitor em projeto de divulgação científica. Tanto Maxwell quanto Fermi, foram através da atuação em escola como professor. E, Mayer, foi através do convívio social com alunos da Licenciatura.

O sentido dado à Licenciatura parece mudar ao longo da trajetória na formação inicial dos nossos sujeitos, mas parece que essa ruptura de concepções é potencializada no contato com o Ensino ou na socialização com os pares. De acordo com as falas, mesmo tendo sido alunos durante boa parte da vida, a ideia de que ser Professor é uma profissão e que para tornar-se Professor o candidato também deve passar por um processo de formação (e transformação) específico, tal como para tornar-se médico ou o engenheiro, não está incutido no pensamento dos entrevistados. Essa ideia e as concepções desses sujeitos, que até então estavam ancoradas no senso comum sobre a profissão de professor, passam por um processo de transformação que toma corpo quando se desiludem com o Bacharelado em Física e se descobrem professores. Além disso, já que esses sujeitos não sentiram perspectivas de mudanças das práticas vindas do curso de Bacharelado em Física, e apesar disso, continuam tendo interesse em Física e Ciência, a Licenciatura parece ser um ambiente mais receptivo e profícuo para esses sujeitos.

\subsection{Início da atuação como professor de Física em escola}

A literatura sobre a formação inicial aponta que o início da carreira é um momento crucial na vida profissional (TARDIF, 2002; BEJARANO \& CARVALHO; 2004). Um momento que compreende muitos conflitos e tensões gerados por crenças incutidas nos recém-formados. É natural e esperado surgirem tensões no início da carreira profissional. Mas as estratégias adotadas pelos profissionais para superarem tais conflitos podem influenciar toda uma carreira. De acordo com as pesquisas sobre o início da carreira profissional, certas crenças prevalecem nos recém formados mesmo depois de todo o processo da formação inicial. Isso significa que a formação inicial de um modo geral, parece não ser bem sucedida em munir os inciantes com ferramentas adequadas que os ajudem na superação dos dilemas próprios do início da carreira. Isso se reflete nas estratégias utilizadas pelos iniciantes, que acabam sendo balizadas pelo senso comum, ao invés de ancoradas nos conhecimentos científicos e acadêmicos. No caso do professor novato, o quadro de conflitos é agravado, pois, geralmente, esses professores experimentam o início da carreira em escolas com estrutura 
fragilizada, em zonas periféricas da cidade e que enfrentam suas próprias tensões. Como consequência, os conflitos e tensões do início da carreira do professor podem nunca serem superados. Desta forma, interessam-nos saber quais foram os principais conflitos e tensões dos nossos entrevistados no início de suas carreiras.

Nesse sentido, os estudos de Fuller (1975 apud BEJARANO; CARVALHO, 2004) e Beach \& Pearson (1998 apud BEJARANO; CARVALHO, 2004) nos ajudarão na categorização e compreensão dos conflitos vividos pelos nossos entrevistados. Fuller propôs um modelo do desenvolvimento do professor de 3 fases: a fase do pré-ensino, caracterizada pela escassa ou inexistente experiência de ensino do sujeito; a fase de preocupações, nos quais o professor tem seus primeiros contatos com o ensino, em que a preocupação é autocentrada na sua própria figura, e ele tenta avaliar os limites de sua aceitação dentro do novo ambiente, é observado a obsessão pelo controle da sala de aula, o medo de não dominar o conteúdo e dificuldades com os processos de avaliação; a fase de preocupações posteriores dirigida aos próprios alunos, seus ganhos e seus processos de aprendizagem. Das sete entrevistas (a informante Mayer não tinha iniciado a carreira ainda) foram identificados que Herschel, Fermi e Planck, estavam na fase de preocupações posteriores no início da carreira, enquanto Gauss, Feynman, Maxwell e Heisenberg, estavam na fase de preocupações. Essas fases foram identificadas nas falas tomando-se por base as principais preocupações que nossos sujeitos tiveram quando iniciaram a carreira.

Beach \& Pearson (1998 apud BEJARANO; \& CARVALHO, 2004) detectaram em seus estudos quatro tipos principais de conflitos que podem surgir no período que compreende o início da profissionalização: 1) conflitos pessoais: em suas relações com os estudantes, com professores cooperadores, colegas professores, administradores. A origem desse conflito surge do insucesso no progresso com os estudantes, pois não concordavam com as crenças educacionais dessas pessoas, mas eles não sabiam como conciliar essas diferenças; 2)conflitos relacionados a questões de currículo e instrução: esse conflito se relaciona principalmente com o fato de, a despeito de prepararem suas aulas com atenção, os estudantes não responderem positivamente a instrução como o professor previa; 3) conflito entre o currículo da escola e o currículo do professor: professores em curso de pré-serviço podem desenvolver conflito relacionado ao seu autoconceito ou papel como professor. Incluem-se aqui problemas com a ambiguidade durante a transição de estudante para professor, os conflitos relacionados à expectativa com o programa da universidade; 4)conflito institucional: que estão relacionadas às dificuldades dos professores para lidar com as complexidades e políticas do sistema escolar e pressões para se socializar com a cultura das 
escolas e do ensino. Analisando as falas dos sujeitos desta pesquisa, podem-se identificar alguns conflitos presentes no início da carreira desses entrevistados:

Só comecei a dar aula quando terminei a licenciatura. Eu estava me sentindo muito segura e com uma concepção bastante idealizada de ensino. Então comecei aplicando o GREF, recém-saído do forno e muito relacionado com minha visão de ensino. Eu tinha todo o material. Mas aconteceu que, apesar dessa segurança e idealização, comecei perceber as dificuldades. O GREF tem muito de o aluno ir construindo os conceitos, e de repente eu me peguei induzindo demais na busca pelas respostas [conceitos]. Chegava num ponto em que os alunos aceitavam o que eu falava, ao invés de entenderem. (Herschel)

Este trecho da entrevista de Herschel permite inferir que esta entrevistada tinha preocupações com os ganhos, em termos de aprendizagem, dos alunos. Portanto, muito provavelmente a entrevistada estava na fase de preocupações posteriores quando iniciou a carreira de professora. Entretanto, o mesmo trecho indica que ela vivenciava o conflito de currículo e instrução. Apesar de a entrevistada compreender a metodologia proposta pelo GREF e tentar trilhar o caminho da proposta, ela percebeu que não conseguia fugir do tradicional e ela revela que acabava fornecendo a resposta pronta ao aluno. Em outro trecho da entrevista, Herschel transparece ainda sofrer o conflito institucional:

Outra dificuldade foi relacionada à questão de aprender a lidar com a realidade de escola que é uma empresa. Tem cobranças e você tem que aprender a trabalhar com isso e aprender a ter jogo de cintura. Existem diretores e outras pessoas que vão cobrar [...] Conquistar o seu chefe, a coordenação, a direção e provar que você faz um bom trabalho é muito exaustivo [...] E o grupo dos professores criava um ambiente muito depressivo. As pessoas não estavam envolvidas, era uma sala silenciosa, professores reclamando, isso me desanimou a ser professora [...] Depois saí dessa escola e fui para uma outra mais perto da minha casa e nessa nova escola a equipe era boa, muito engajada com a educação e as discussões nas reuniões eram interessantes, então eu comecei a ficar animada. (Herschel)

O que esse trecho indica é que, provavelmente, a crença de Herschel era a de que como estava lidando com ensino, ela não esperava que a escola "jogasse as regras" do mundo empresarial. Além disso, a cultura escolar pouco produtiva no qual ela se inseriu não condizia com as suas próprias expectativas. O entrevistado Feynman, que foi identificado como estando na fase de preocupação ao ingressar na carreira, também revela ter vivido, além dos conflitos pessoais,conflitos de currículo e instrução e conflito entre o currículo de professor e o da escola:

Quando assumi como professor numa escola particular, na minha primeira semana de aula, eu estava cheio de empolgação e fiz um jogo com os alunos que deu muita confusão, teve briga. Essa foi a primeira briga em sala de aula de várias. Com relação a outras coisas, o aspecto que envolve o Conteúdo, é o aspecto que "pega" um pouco, porque o Conteúdo que a gente estuda na Licenciatura é diferente do conteúdo que é trabalhado em sala de aula. Então o professor é formado fora do contexto ideal. Eu levei um tempo para me adequar ao contexto. (Feynman)

Esse trecho aponta para o conflito de instrução, pois, a despeito do entrevistado ter feito uma tentativa de ensino utilizando uma abordagem que, numa primeira aproximação, 
deveria ser interessante e divertida para os alunos, o resultado foi o avesso disso. Outro conflito identificado foi o relacionado aos currículos da escola e do professor. Feynman propõe que os conteúdos aprendidos na Universidade são diferentes dos da escola, tanto em métodos como em abordagens. Feynman continua:

Em alguns momentos, os alunos não vão entender o professor e não tem o que fazer,
o professor vai ter que descobrir o porquê de os alunos não estarem entendendo,
voltar e se adequar. Como evitar que aconteça de uma forma com consequências
grave? Por meio de processo avaliativo constante, a avaliação como processo
constante permite identificar o que está acontecendo na sua turma, se foi algo que
faltou na parte de ensino. Mas eu acho que não foi muito bem trabalhado na
graduação [...]. Existiu a discussão no curso, mas não foi enfatizada a importância
que isso tem. Porque se deve ter claro que o estudante universitário está em processo
de formação e no caso da licenciatura, é muito complexo, porque o estudante de
graduaçâo se forma e vai para a sala de aula e vira um "Propagador de erro".
Quando ele sai e vai pra sala de aula, sofre muitas coisas por falta de experiência,
então fica muito complicado. Tem coisas que o professor somente vai aprender com
a experiência mesmo, em sala de aula, não tem jeito, mas tem coisasno processo de
formação. Que poderiam auxiliá-lo melhor. (Feynman)

Esse trecho revela claramente o desapontamento desse entrevistado com a Licenciatura que para ele falha em munir o sujeito com estratégias para lidar com as adversidades da sala de aula. A adversidade, no caso desse trecho, é a preocupação em saber avaliar se o ensino e a aprendizagem estão sendo bem sucedidos. Com exceção de Planck e Maxwell, desprendem-se das falas de 5 sujeitos 2 ou mais conflitos. Beach \& Pearson (1998 apud BEJARANO; \& CARVALHO, 2004) também identificaram estratégias que os professores utilizam para enfrentar os conflitos. Os autores sugeriram uma tipificação das estratégias em três níveis hierárquicos:

Nível I: Atitude de negação, recusa e afastamento dos conflitos, com evidências de declínio com o passar do tempo, sem questionamento sobre as crenças sobre o ensino e aprendizagem. Participantes descrevem o conflito mascarando-o ou racionalizando$\mathrm{o}$;

Nível II: Solução de curto prazo, tentativa de mudar os fatores externos (disciplinando os alunos, por exemplo), pouca interrogação sobre as teorias pessoais de ensino ou sistema de crenças;

Nível III: Consciência da complexidade do ensino, tornam-se abertos a interrogar suas próprias percepções e teorias de ensino, sentimento de necessidades de mudança, reconhecimento de que visões simplistas não explicam a complexidade da escola.

Infelizmente, os nossos dados não permitiram obter informações suficientes para ser possível identificar as estratégias utilizadas por cada sujeito na tentativa de solucionar seus conflitos. Contudo, as falas parecem sugerir que não houve espaços suficientes dentro da 
graduação para a discussão dos conflitos e das preocupações que podem surgir da prática. Uma hipótese plausível, contrapondo a visão dos sujeitos, é que tais conflitos pudessem talvez não existir ou não ter sentido no momento da graduação. Por esse motivo, até pode ter havido discussões sobre alguns dos aspectos relacionados aos dilemas de início de carreira (ao menos, a partir de 1993, essa era a proposta do Projeto Pedagógico da Licenciatura em Física), mas como não fazia sentido para os entrevistados naquele momento de formação inicial, elas não foram significativas. Corroboram com essa hipótese as trajetórias dos entrevistados Maxwell e Fermi. Como Maxwell teve especificamente a experiência de professor em sala de aula em escola do ensino básico, antes de ingressar na licenciatura, ele viveu a experiência concreta dos problemas e das demandas da sala de aula (conhecimento na prática):

\begin{abstract}
Como eu não tinha um percurso na Licenciatura [...] Nesse momento eu não sabia fazer Plano de Aula, não sabia fazer Diário, não tinha sido preparado para nada disso. Mas foi uma experiência boa, dei aula para o Fundamental 2, aprendi um monte de coisa com os alunos e descobri que para ser professor necessitaria de uma preparação [...] Quando eu dei aula eu tive minha primeira experiência com formas diferenciadas de avaliações isso me marcou e me chacoalhou. Nas disciplinas aqui [na Licenciatura] ficou claro o porquê daquilo estar sendo feito daquela maneira. Eu dei uma sorte de cair numa escola com uma equipe muita boa e que fazia avaliações das mais diversas formas e isso me influenciou profundamente. Na escola particular, nós tínhamos que fazer uma prova tradicional, mas o restante, eu fazia das mais diversas formas. Sempre valorizei o laboratório e ele fazia parte do processo avaliatório. (Maxwell)
\end{abstract}

A conjuntura traçada por Maxwell indica que quando este sujeito ingressou na Licenciatura em Física, ele "já sabia o queria saber". Isto é, a experiência concreta na sala de aula propiciou ao sujeito a formulação de perguntas nos quais esperava que a Licenciatura proporcionasse as respostas, por esse motivo, até mesmo sua visão sobre algumas disciplinas era diferente da de outros alunos da Licenciatura:

\footnotetext{
Quando eu vim, eu vim querendo ser professor e eu percebia em alguns colegas, na disciplina da Educação certo desprezo por elas, mesmo em colegas da Licenciatura. E para mim, aquilo discutido na disciplina era muito importante, eu discutia isso com eles, eu falava que não dava para ter essa postura. Tudo bem, você pode não gostar de um texto, ou não gostar de um professor, mas a discussão sobre didática, por exemplo, é super fundamental. (Maxwell)
}

Fermi também vai para a Licenciatura depois de iniciar na carreira de professor. Assim como Maxwell, ele vivenciou a experiência concreta na sala de aula. As falas não revelam, mas supomos que talvez este sujeito tenha ingressado na Licenciatura com expectativas de "solução" para conflitos que provavelmente ele vivenciou. Essa suposição pode ser feita com base na seguinte revelação que Fermi faz sobre a Licenciatura:

Algumas coisas sim, por exemplo, saber entender como o aluno pensa, a gente entende, mas sinceramente, em minha opinião, tinha muita coisa que na prática não 
se enquadra direito. Muita matéria que eu fiz da Faculdade de Educação, mas você não sente respaldo. Você tem que fazer porque tem que fazer, mas não dão respaldo para a sala de aula. Eram teóricas demais, você lia alguns autores e discute o que eles pensam, mas não sei, talvez por esses autores serem do estrangeiro ou terem alunos ideais, educados, formados, não condiz com a realidade do Brasil, que são alunos que não tem bagagem, não tem pré-requisito, que você tem que montar o prérequisito com o aluno. Mas como eu já estava dando aula durante as aulas na graduação (...) elas [as disciplinas] não se adequam a realidade da sala de aula. Era muito distante o que era tratado lá, do que eu vivia. (Fermi)

As falas de Maxwell e Fermi sugerem a seguinte asserção: não é que a hipótese de como a experiência concreta em sala de aula auxilia os Licenciandos na formulação de perguntas esteja equivocada. Mas parece que, se a escola na qual o sujeito se inicia proporciona experiências positivas sobre o ensino e a aprendizagem, o graduando consegue enxergar na Licenciatura o "respaldo" que necessita. Mas, se a escola não for capaz de proporcionar tais experiências (por falta de estrutura, por exemplo), o licenciando parece não perceber ajuda vinda da formação inicial. Acontece que, como sugere Fermi, a situação das escolas no Brasil está ruim e os problemas tão complexos, que parece "não haver saída".

Algo similar parece ocorrer ao sujeito que inicia a carreira depois de formado. Se a escola que receber esse professor novato oferecer condições favoráveis e desse modo, os sujeitos perceberem apoio vindo da equipe pedagógica ou da equipe de professores, isso os ajudaria a criar estratégias eficazes de superação dos conflitos. Parece ter sido isso o que aconteceu com Planck:

Era uma escola com uma visão de ensino que não era tradicional. Acho que a ideia que a Diretora implantou na escola era muito próxima ao que a gente discute aqui [na graduação] sobre Educação, sobre Ensino de Física. Por isso, não tive tantos problemas. A parte prática eu não sabia, mas a Diretora foi dando todo apoio, muita coisa aprendi sozinho. (Planck)

Mas, se a escola não for capaz de oferecer tais condições, o que as falas sugerem é que o professor novato acaba tendo que criar suas próprias estratégias, tal como Heisenberg fez:

Eu tive uma professora de Física no colegial que era meu exemplo de como ser um professor. Ela era autoridade sem ser autoritária. Eu buscava exemplos de como dar aulas nos professores que tive no cursinho. Eles eram cínicos, faziam umas perguntas e eles mesmos respondiam, de uma forma engraçada, mas menosprezando os alunos. (Heisenberg)

Além da escola (equipe pedagógica, coordenadores e professores,) parece que a PósGraduação e cursos de formação continuada também conseguem fornecer os subsídios necessários aos iniciantes na profissão de professor e fazer o papel de coach:

Como eu já fui direto da graduação para o Mestrado, lembro que tinha reuniões com a minha orientadora e era uma terapia. Porque ela me ajudava, tirava dúvidas em relação às aulas, como fazia com aquele aluno indisciplinado, por exemplo, (...) Então foi depois de formado, durante o mestrado tive outras noções. Isso ampliou o meu leque de aprendizado. (Heisenberg) 
A hipótese que se configura é que parece que os conhecimentos teóricos estudados na graduação são melhores assimilados e parecem fazer mais sentido para os sujeitos quando ocorrem concomitantes às experiências concretas na sala de aula. Também sugerem que provavelmente conflitos surgirão no início da carreira, mas segundo nossos sujeitos, o papel de um professor-formador (ou mentor) ou de uma equipe (pedagógica, de coordenadores ou de professores) que seja capaz de mediar a prática desse iniciante se configura como fundamental para ajudar os iniciantes a superar os conflitos de maneira eficazes.

\subsection{As disciplinas: visões, opiniões e elementos marcantes.}

\subsubsection{Disciplinas da Física (Conteúdo a ensinar)}

Em 1993, o currículo da Licenciatura em Física do IFUSP passou a contar com uma grade própria. Isso significa, entre outras coisas, a possibilidade de oferta de disciplinas com enfoque específico para a Licenciatura dentro do Instituto de Física. Essa proposta visou possibilitar que aspectos próprios da profissão de professor pudessem ser trabalhados também dentro das disciplinas de conteúdo Físico, a ensinar, isso quando o docente se dispusesse a fazê-lo. Com isso em mente, buscamos ouvir dos sujeitos entrevistados suas opiniões e visões sobre as disciplinas da Física da grade da Licenciatura. O intuito foi o de fazer um levantamento sobre os elementos que foram importantes e marcantes para esses sujeitos nessas disciplinas.

\section{Autonomia ou autodidatismo?}

Uma primeira informação que se depreendeu do texto ainda na etapa da leitura flutuante foi sobre a percepção que os sujeitos têm de que as disciplinas de Física - e algumas da Matemática - propiciam aos alunos o desenvolvimento de uma autonomia. Esse termo aparece especificamente em três das oito entrevistas: Heisenberg, Feynman e Gauss. O sentido que esses sujeitos dão a essa palavra está relacionado ao "saber se virar" para buscar conhecimento, sem ajuda do professor ou sem depender da aula. Sem utilizar a palavra “autonomia”, Herschel e Maxwell fazem menção a mesma alegação: 
também fiz cursos em outros lugares [...] E assim vamos ganhando elementos e se aprofundando. [...] Toda essa parte de física moderna e contemporânea, evolução do universo, eu tive uma pincelada no curso, mas fui aprender mesmo fora." (Maxwell)

"Porque Física Matemática foi importante? Porque eu posso pegar qualquer assunto, leio, vejo a equação e sei interpretar a equação, a conceituação você lê, então. Mas eu adoro pesquisar, isso é importante, eu sabia onde estava a informação, e eu sou da época que não tinha internet, então era livro, eu tenho uns livros, uma biblioteca pequena por causa da graduação, mas que me ajudava também [...] nós no IFUSP éramos tratados de uma maneira muito madura, então não tinha obrigatoriedade de entrar na sala de aula, mas a cobrança era alta, então a gente tinha que estudar muito. Então, a autodisciplina aqui e a maturidade era muito importante. (Herschel)

O que nossos entrevistados chamam de autonomia e que parece ser algo positivo está relacionado à competência e a disposição para aprender apesar da falta do suporte que poderia ser oferecido pelo professor ou pela instituição. Acontece que muitas instituições de ensino superior avaliam com rigor, mas oferecem pouco suporte aos estudantes ou de maneira descomprometida (LIMA JÚNIOR, 2013). Já os professores, por vezes, se justificam por meio do propósito razoável de formar profissionais autônomos. Isto acaba inculcando nos alunos que eles são os principais e, na maioria das vezes, os únicos responsáveis pela própria formação. Isso foi o que se percebeu pelas falas dos entrevistados:

A USP me deu autonomia [...] Apesar de eu ter reprovado em algumas disciplinas, acho esse processo importante para quem quer conseguir realmente se virar na vida. Tanto que hoje em dia, se eu encontrar algum problema [relacionado às aulas] pela frente e não ter ninguém para ajudar, eu sei me virar. (Heisenberg)

Uma das coisas que o curso na USP gera pra gente é a questão de autonomia e capacidade de adaptação [...] O conteúdo que estudamos em física, quando vamos resolver um exercício de Mecânica na graduação, por exemplo, derivamos e integramos. Quando trabalhamos com ensino médio, não derivamos e integramos. Então, resolver exercícios como os de Ondas, é difícil então essa adaptação é necessária [...] Outro exemplo: eu estava fazendo Eletromagnetismo 2, com um professor que não falava português direito, então não existia um meio de comunicação eficiente. Isso fez com que eu tivesse que me virar fora. Existem outros episódios que remetem a isso [...] quando eu estava fazendo uma disciplina com um professor que falava muito baixo, nós não escutamos o que ele dizia, além disso, e ele falava virado para a lousa, escrevendo no quadro. Nós entendíamos algo quando ele virava, mas ele apenas falava "é claro que..." Então foi um processo de adaptação. [...] Outro episódio marcante da minha graduação ocorreu quando eu morava em [cidade fora da Capital] e, em um dos dias que eu estava indo pra USP, choveu muito, de alagar a cidade. Mesmo assim eu fui pra USP. Cheguei lá molhado. Tive uma aula horrível e na sequência foi outra aula horrível e eu pensei que não iria mais assistir essas aulas. Então não assisti mais a essas aulas e só fui fazer a prova. Porque com alguns professores, você assistindo ou não a aula, se esforçando para chegar na aula, é basicamente a mesma coisa. Então isso faz com que você tenha que se virar. E se virar de diversas maneiras. Desde encontrar livros que você entenda e que se assemelha ao conteúdo do professor. Pegava vários livros para conseguir entender a aula. E esse é um processo de aprender a se adaptar. (Feynman)

Alguns professores são rudes. Um dia que uma aluna saiu chorando da sala, o professor não se preocupou [...] Além disso, a lousa dele era rabiscos, garranchos, garrancho pequenos, escrevia fraco [...] Quando alguém reclamava, o professor era rude. [...] então das aulas, eu não conseguia extrair nada, estudava dos livros. Disso 
eu comecei a ter autonomia na graduação. Tem um lado bom. Eu aprendi a estudar sozinho, aprendi algo? Não totalmente, mas deu certo para ser aprovado. (Gauss)

O que percebemos é que, embora essas ações possam contribuir para formar alunos mais "autônomos", em contrapartida, o ambiente parece ser hostil para muitos deles. Isso não é uma surpresa, visto que não é que o professor esteja fomentando a autonomia, é apenas que os alunos não percebem ajuda alguma partindo desse professor ou de um conjunto de professores e se veem obrigados a solucionar sua formação por conta própria, fomentando, em muitos casos, o individualismo. As falas dos nossos entrevistados sugerem ainda que eles percebem que alguns professores do curso são por vezes marcadamente alheios ao currículo ou ao Projeto Pedagógico, individualizados. Isso acarreta que as disciplinas acabam sendo planejadas e executadas sem se levar em consideração o curso, a necessidade formativa ou os interesses dos alunos. Masetto (2003) diz ser isso uma consequência de graduações em que as disciplinas são concebidas como independentes do projeto pedagógico, então cabe ao aluno descobrir sozinho o significado para o seu curso e sua profissão (MASETTO, 2003). Com isso, podemos inferir que o que os entrevistados nomeiam como "autonomia", na verdade parece ter outro sentido, que se aproxima mais do autodidatismo. Isso pode ser uma consequência de um ambiente hostil, nos quais as falas dos entrevistados indicam que é legitimado pelas ações de alguns professores que são indiferentes às necessidades dos alunos e negligentes em suas atividades, deixando de fornecer suporte quando possível e necessário. De acordo com as informações trazidas pelos profissionais entrevistados, isso acontece no Bacharelado em Física em maior grau (o que parece ser um dos motivos da evasão neste curso) e também na Licenciatura em Física. Embora aconteça nas disciplinas da Licenciatura, existem outros fatores concorrentes que parecem conseguir garantir a permanência dos alunos nesse curso, como trataremos mais adiante.

As maneiras com que os entrevistados se referem às suas experiências autodidatas são bastantes variadas: alguns com orgulho, outros com frustração e indignação. Ao mesmo tempo, associam a autonomia (autodidatismo) a outros temas importantes que nos permitem perceber mais precisamente como foi a experiência desses alunos no Instituto de Física. É justamente a análise dessas associações temáticas que pretendemos nesta seção.

Em primeiro lugar, e mais frequentemente, os alunos alegam negligência dos professores. Argumentam que, embora haja professores muito competentes e dedicados no Instituto de Física, há também aqueles que prejudicam ou deixam de contribuir substancialmente para o aprendizado dos alunos: 
Alguns professores faziam os alunos refletirem sobre o papel do Físico. Os demais despejavam o conteúdo, lista de exercícios, prova. Eram matérias interessantes. Alguns tiravam dúvida, professores, mas não no sentido que eu aprendi a entender como ser professor. Era no sentido que estava acostumado [na graduação]: uma pessoa que joga o conteúdo na lousa e os alunos tinham que se virar. (Maxwell)

Nas disciplinas da Física, parece que a distância entre o aluno e o professor é enorme. Se você tem uma dúvida, parece que problema é do aluno. O aluno tem que se virar [sic] para descobrir, para sanar a dúvida. Ou ainda, os professores passam a impressão de que se o aluno tem dúvida porque não estudou o suficiente. (Planck)

Sobre as disciplinas específicas da Física, alguns sujeitos reclamaram ainda da presença de professores sem formação específica no Ensino de Física:

[...] nas escolas básicas o professor deve ter outro perfil. Aqui eles não são professores, são pesquisadores que têm que dar aula. Infelizmente, aprendi o conteúdo que eles estavam apresentando, alguns virados para a lousa o tempo todo, tanto que tínhamos que esperar eles saírem da frente para você entender qual era a matéria do dia. (Maxwell)

Complementos de Mecânica fiz com uma professora que no Bacharelado é adorada [...] ela sempre deu Mecânica 1 ou Mecânica 2 e ela veio dar a disciplina para a Licenciatura, mas acho o curso muito ruim. Não porque ela é uma professora ruim, mas ela não conseguia se comunicar com os alunos. Além disso, por ser muito formalista, apesar de muito entusiasmada com a matéria, ela focava a aula em um tipo de raciocínio apenas. Tanto que em algumas aulas ela se recusou a fazer alguns exercícios. Ela alegou que não teríamos capacidade matemática para isso. Isso demonstra que ela não está entendendo o público dela, não está tendo empatia e nem humildade. Ela não teve condição de pensar que quem ela está formando são professores e ela não deveria agir assim com professores. (Gauss)

Uma inferência que essa fala permite fazer é que a participação de docentes do Bacharelado no curso da Licenciatura é bastante permeável a professores que parecem não compreender o "seu público alvo", tal como a afirmação de Gauss acima.

Um fato curioso é que os sujeitos entrevistados que se formaram há mais tempo, ou não tinham muito a falar sobre as disciplinas da Física, ou quase não se queixaram delas. Por vezes, as falas sugeriram um olhar mais positivo por parte destes entrevistados (a não ser sobre as disciplinas de Física Experimental, a qual trataremos mais adiante). Porém, conforme comparamos as falas dos sujeitos em ordem cronológica de tempo entre os formados, aqueles entrevistados com menos tempo de formação apresentavam uma visão mais crítica e até mesmo mais dura sobre as disciplinas. Parece haver uma relação inversamente proporcional entre o tempo de formado e o olhar mais crítico.

\section{Disciplinas da Física e a profissão de professor}

No momento do depoimento de cada sujeito, a entrevistadora questionou como os professores das disciplinas da Física levavam para as aulas algum conhecimento, informação 
ou dimensão da profissão de professor. O objetivo era o de compreender se, na visão dos entrevistados, era perceptívelo compromisso dos professores com a valorização do perfil do profissional que estavam formando. Apenas um sujeito, o Feynman, conseguiu identificar com clareza a valorização deste aspecto partindo de uma professora: "os cursos de uma determinada professora eram bons, pois ela tinha toda essa questão de trabalhar as concepções que os alunos possuem e discutir isso com a gente" (Feynman). Os outros sujeitos entrevistados não conseguiram fazer essa identificação com clareza.

O que as falas dos sujeitos parecem revelar, entretanto, é que algumas ações de alguns professores são marcantes, mesmo os sujeitos não tendo clareza se isso faz parte ou não de uma tentativa do professor de levar para a aula da graduação aspectos da profissão de professor. Ficaram marcadas para os sujeitos principalmente aquelas ações que parecem contribuir com dimensões didáticas e metodológicas do ensino. Mas, no geral, são tentativas que se configuram como isoladas e até mesmo impensadas, que dependiam muito das características do docente. Por exemplo:

Um dos cursos mais tenebrosos que eu tive foi o curso de Física Moderna, um curso difícil, mas aprendi algumas coisas com essa professora. E uma das coisas eu aprendi é ser coerente nas provas, a prova dela era difícil, mas era coerente com a aula, e isso é algo que não acontece, tem muitos professores que dão uma aula em um nível, mas cobra outro muito mais alto. No caso dela não, o nível de dificuldade era coerente com o que aprendemos. (Feynman)

O que a fala de Feynman indica é que mesmo que o objetivo específico da professora não tenha sido o de colaborar com a compreensão dos sujeitos sobre o processo de avaliação, a sua ação avaliativa foi vista como um exemplo de boa prática docente. Isso marcou o entrevistado. A fala demonstra que Feynman, ao comparar as disciplinas da Física, nota que aquela professora elabora uma prova coerente com as aulas. Isso sugere que essa prática foi encarada pelo entrevistado como uma exceção à regra, no caso daquelas disciplinas. Fermi também contribui com algo no mesmo sentido, mas no que tange às "passagens" dos cálculos pelos professores:

Tive dois professores que me marcaram muito, que foi quando fiz Física três e quatro e Mecânica dos Fluidos. Me marcou profundamente porque os professores tinham uma aula profunda, uma didática diferente dos outros professores do IF e eu tento seguir a linha. Eles conseguiam explicar coisas pesadíssimas, mas era de um jeito que todo mundo ficava preso. Uma didática, uma simplicidade, como se estivesse dando aula para criança. Tanto que na lousa, quando resolvo exercício, eu vou passo a passo, justamente por causa deles. Vamos resolver essa equação: pegar na mão e não pular etapa. E consegui ter essa visão, através dessas disciplinas. Fazer passo a passo, quando você ia ver, estava aquela conta grande na lousa, mas quando você pegava o seu caderno para estudar, você conseguia entender as etapas. (Fermi)

Quando o sujeito enfatiza a ação do professor na disciplina, ele acaba revelando que essa foi uma boa prática valorizada. Para o Fermi, no caso, a boa prática do professor foi a de 
não "pular" passagens ou etapas de cálculos ou demonstrações e conduzir a demonstração explicando cada passo do pensamento em uma dedução ou resolução de um exercício difícil mesmo que algum dos passos seja trivial. Isso vai ao encontro da ideia do entrevistado anterior já que a fala sugere que essas práticas não foram comuns ao longo da graduação desses entrevistados. Então, se algum professor se preocupa com a demonstração de tais passagens ou elabora uma prova coerente com a aula,isso acaba marcando positivamente os alunos.

Apesar dos Projetos Pedagógicos da Licenciatura em Física do IFUSP preconizarem a valorização de aspectos da profissão de professor também nas disciplinas da Física, parece que para o entrevistado Fermi não é esse o papel dos professores nessas disciplinas:

\begin{abstract}
Acho que a disciplina de Física Moderna ficou muito mais próxima da Física do Bacharelado do que da Licenciatura. Mas ainda assim o professor conseguia levar alguns aspectos da educação. Não era puramente conta e coisas do tipo. Ele discutia os fenômenos e conceitos da Física Quântica, mostrava os cálculos. Tratamos alguns fenômenos com bastante cálculo, mas não tanto quanto no Bacharelado, mas algumas aulas ele trazia um aspecto mais, não era histórico, era mais experimental acho, numa abordagem mais prática. [...] não tinha tanto uma relação com ensino, acho que seria legal, inclusive o professor dessa disciplina, tratar um pouco da Física Moderna dentro do contexto do Ensino Básico, e isso não aconteceu. Essa abordagem ou discussão não teve, talvez seja por isso que eu tenha achado que tenha ficado mais perto do Bacharelado. Mas envolve toda uma questão curricular, não sei se o professor teria paciência para discutir tudo isso, é muita coisa, porque você fala: e no ensino, como é que é? E isso torna a discussão muito longa. (Fermi)
\end{abstract}

Ao falar sobre a disciplina de Física Moderna, a fala de Fermi parece elucidar alguns pontos que são preocupantes, pois revelam crenças incutidas tanto em professores (da graduação ou do ensino básico) quanto em alunos dos cursos de Bacharel em Física e Licenciatura em Física. O primeiro ponto sugere que tanto o professor como o aluno parecem não saber o que seria um enfoque profissional para uma disciplina de Física para a Licenciatura: Fermi afirma que o professor discute os conceitos e traz menos carga matemática - o que não se constitui de um enfoque profissional específico, nem do bacharelado e nem da licenciatura, haja vista que no bacharelado também devem ser discutidos os conceitos e a fenomenologia da Física, e na licenciatura, não significa colocar em segundo plano o formalismo matemático. Já Maxwell reclama da falta de uma discussão epistemológica, o que demonstra que este sujeito considera esse tipo de enfoque, um enfoque mais profissional:

Por exemplo, toda essa discussão sobre o Big Bang, Relatividade Geral, não vi nada disso. Nem como introdutório. Por exemplo, numa introdução sobre a Evolução do Universo com os alunos, usando o que aprendemos de Física Moderna e Contemporânea na graduação, não conseguiria. Eu dou. Aprendi depois. Mas, tem uma parte matemática que eu não sei. Eu senti isso, saí do curso sem olhar para a física do século XXI. Eu não conseguia falar nem da física do século XX direito. A 
gente tem na grade um curso de Laboratório e um curso de Física Moderna. Mas não foi um curso que foi discutindo epistemologicamente o que está acontecendo. Essa discussão, por exemplo, sobre o caminho epistemológico que aconteceu, eu fui ver depois, num curso de um colega da Pós-Graduação. Era um curso de Epistemologia e os Modelos da Física. (Maxwell)

O outro ponto é que Fermi parece querer que se discuta a Física Moderna do Ensino Básico na disciplina, mas, como o próprio Fermi admite, não caberia no tempo disponível. A fala sugere, portanto, uma hipótese de que os professores até procuram seguir o que está escrito no Projeto Pedagógico do curso em relação aos aspectos da profissão, embora sem uma compreensão adequada. A fala de Feynman contribui com essa compreensão:

\footnotetext{
Óptica foi com um professor era meio "terrorista" e sempre que você falava alguma coisa sobre a Física ele indagava o porquê você está falando isso? Então você tinha que pensar muito antes de falar alguma coisa para não falar bobagem, era interessante porque você sabia que se falasse alguma bobagem ele iria voltar para você e você ia ter que repensar e reformular aquilo que você falou. A aula não era ruim. Pelo contrário, era interessante. Tinha umas coisas bem interessantes, por exemplo, de vez em quando tinha umas provas surpresa no fim da aula, então todo mundo ficava até o final da aula porque não sabia se ia ter prova [...] Alguns fazem coisas que você não quer colocar na sua prática e outros trazem coisas que você quer colocar na sua prática, às vezes com uma característica diferente, mas todo professor acaba trazendo alguma coisa positiva ou negativa. E no caso dele tinhas as duas coisas. (Feynman)
}

Essa fala sugere que Feynman percebeu que mesmo o docente da disciplina não estando abordando diretamente a questão da didática e da metodologia do ensino, a prática questionadora do docente em relação ao raciocínio dos alunos impactou este egresso e foi positiva para sua formação profissional.

Todavia, com as mudanças ocorridas nas grades da Licenciatura em 2006 e 2015 no que diz respeito à Prática como Componente Curricular, era esperado que os sujeitos que vivenciaram essas grades pudessem contribuir com alguns elementos sobre como esse aspecto foi abordado em sala de aula pelos professores da Física. Entretanto, apenas Gauss trouxe um parecer sobre isso:

Aqui! Aqui sim houve o que você perguntou [sobre ter elementos da profissão de professor na aula], em Mecânicas dos Corpos Rígidos e dos Fluidos. Eu fiz com a professora que hoje é minha orientadora. Essa disciplina tem crédito de trabalho e nos créditos de trabalho dela, dava atividades experimentais que a gente fazia virtualmente, então era meio que assim, às vezes a atividade é numa sala mesmo, experimental de fato, às vezes era virtual. E ela tem isso, de falar. Ela não é da área de ensino, mas ela é muito bem informada e muito entusiasmada. Ela não tem experiência em educação básica. Mas ela sempre tenta transmitir para os alunos as dificuldades e problemas epistemológicos até dos cursos de antigamente, então ela deu muitas vezes esse curso. Mas esse curso de mecânica ela reformulou, mudando a ordem dos assuntos, pulando assuntos, introduzindo assuntos, ela tem hoje estabelecido um caminho epistemológico para a disciplina e como o conhecimento vai evoluindo que não está em nenhum livro, é dela, apesar de usar livro texto. (Gauss) 
A fala de Gauss sugere que ele encara como sendo um enfoque profissional a discussão epistemológica do conteúdo e das dificuldades que os alunos podem apresentar sobre os conceitos. Também parece que valoriza a autonomia e a criatividade do professor ao elaborar um plano de aula e valoriza também quando o docente da disciplina focaliza aspectos históricos e objetivos transversais da física. Maxwell também parece valorizar quando o professor aborda temas transversais:

Em Eletromagnetismo, mesmo sendo um curso de Bacharelado, cheio de matemática, com muita Física, o professor procurou transcender em muitos aspectos e sair da caixinha. Ele discutia aspectos da religião judaica cristã e como isso influenciou o pensamento ocidental e, portanto, a ciência que a gente estuda. Então ele sai do conteúdo da Física, dialogando com outros conhecimentos e traz para dentro da Física. Isso é fascinante. (Maxwell)

\section{Gravitação: a menina dos olhos}

$\mathrm{Na}$ contramão em relação aos sentidos dados pelos sujeitos às disciplinas da Física (conteúdo a ensinar), a disciplina de Gravitação, no que concerne a abordagens epistemológicas, fenomenológicas e históricas dos conceitos e fenômenos, parece ter sido a "menina dos olhos" dos alunos da Licenciatura. Essa disciplina foi tratada com muito cuidado pelo Projeto Político Pedagógico de 1993 e parece ter sido um dos grandes trunfos das mudanças ocorridas nessa época e, de fato, são muito apreciadas pelos nossos informantes. Inferimos das falas de Maxwell (formado em 2002), de Planck (formado em 2014) e de Mayer (ingressante em 2015) um teor que sugere que essa disciplina marcou muito nossos entrevistados:

Quando eu entrei na Licenciatura, a primeira disciplina que eu fiz foi Gravitação, E me abalou. Vim para essa disciplina de Gravitação pensando que ia ser fácil. Mas o pessoal falava que essa tinha uma "pegada" [sic] histórica, e eu pensava que ia ser muito legal. Mas foi um "chute na cara". Divertido, porque eu nunca tinha pensado sobre isso, para você ver, no Bacharelado você vai estudando [mecanicamente], tem a beleza própria do conhecimento, mas não se se reflete sobre o conhecimento. Então o curso começa discutindo o conceito de gravidade. Você se pergunta como assim a gravidade não é a Newtoniana? Como assim? A gente não para para pensar em gravidade Einsteiniana [sic]. Eu nunca tinha conectado o que eu estava fazendo com os modelos de gravidade. E essa questão de modelagem me pegou. (Maxwell)

O professor na disciplina de Gravitação abordou bastante a parte histórica da Gravitação, ela foi umas das primeiras disciplinas que começou a abordar a questão histórica. No Bacharelado não existe isso, a abordagem histórica da Física não acontece, somente exercício. A Gravitação trouxe uma problemática do ponto de vista do cientista da época. Então você começa a pensar como o cientista pensou no contexto da época dele, você começa a pensar como que Newton pensava, no contexto dele. Tinha toda a parte de religião envolvida, de como o mundo funcionava naquela época, o que já tinha sido descoberto ou o que não tinha. Essa disciplina começou a abrir o meu olhar e descobri que falar de física vai muito além do exercício. Não é só sentar e ficar fazendo exercício. Tem coisas, além disso, tem toda uma construção. Você começa a compreender a Física como uma construção humana, ferramenta que vai se desenvolvendo. (Planck) 
Somente na disciplina de Gravitação a professora discutiu ou levava aspectos do ensino de Física para a aula. Gravitação não é sobre o Ensino de Física, é uma matéria de história e tem um pouquinho de Física, mas vamos vendo historicamente como as teorias da Gravitação e a matemática foram se desenvolvendo ao longo da história. Não é propriamente de ensino, mas durante a aula a professora vai falando: isso aqui é um método de ensino que a gente conhece capaz de ajudar aluno com tal coisa ou que ajuda o aluno do Ensino Básico a entender tal ponto. Por exemplo, teve uma vez e a professora deu para nós umas folhas para fazermos as elipses e desenhar os pontos das órbitas dos planetas com alfinetes e com um cordão, Método do Jardineiro, colocar duas estacas e fazer a elipse com corda, com o objetivo de olhar a elipse e olhar para as órbitas e saber que apesar de fazermos elipses, elas parecem circulares. Então ela passou isso para começar a falar de Kepler e no final ela falou: se vocês olharem vocês pensam que são elipses? Não, é um círculo! Por isso que as pessoas achavam que as órbitas eram circulares... E no meio disso ela falou que isso era um método que poderia usar com os alunos. Os outros professores não têm isso. (Mayer)

O que essas falas estão sugerindo é que essa disciplina causa um impacto positivo na formação - estes sujeitos parecem valorizar abordagens fenomenológicas e históricas da Ciência e da Física nas disciplinas -. Então, quando em uma disciplina o professor apresenta essa abordagem como mote do processo de ensino, esses entrevistados acabam se sentindo revigorados como alunos e reconectados com a Física. Entretanto, o cuidado em levar para a disciplina de Gravitação essa abordagem, ao que a fala do Gauss indica, parece depender do professor:

Gravitação era para ser um curso com um viés histórico, mas eu fiz o curso com um professor da Física Matemática. O curso foi basicamente aprender a manipular equações. Tanto que ele tentou, mas não deu certo, falar de teoria de perturbação. Nem sei direito o que é isso, e uma coisa que ele fez foi deduzir com cálculo as Equações de Kepler, que é uma coisa que fui ver direito e que entendi somente em Complementos de Mecânica. Foi terrível, acho que é um erro dar esta disciplina a pessoas que não sejam da área da História da Ciência. Acho que é um erro institucional e estrutural. (Gauss)

Comparando a fala de Gauss com as de Mayer e de Planck, o que se configura é que o Gauss provavelmente tinha conhecimento da reputação da disciplina de Gravitação no que tange abordagens históricas e fenomenológicas. Mas parece que ele se sentiu frustrado ao não ter sido oportunizado para a sua "turma" a mesma abordagem que os outros entrevistados presenciaram. Essa frustração reitera a percepção que nossos entrevistados têm de que disciplinas com viés histórico-epistemológico dos conceitos físicos parecerem ser conectadas com a profissão, além de serem muito apreciadas por esses sujeitos. Maxwell também revela um pouco de frustração:

[...] a gente tem um curso de Gravitação no primeiro ano, com a abordagem histórica, mas depois não temos mais uma retomada daquilo [das discussões histórico-epistemológicas]. Não conseguimos refletir. Fico me perguntando, quais influências que o curso aqui do Instituto de Física tem para só ter isso uma vez. (Maxwell) 
Apesar de esse sujeito ter tido um curso de Gravitação que possibilitou discussões de cunho histórico, parece que para ele faltou um pouco dessa abordagem em outras disciplinas. A impressão que essa fala sugere é a de que ocorre compartimentalização dessa abordagem a essa disciplina. Essa é uma reivindicação implícita de Maxwell de que deveria haver outras disciplinas que abordem aspectos históricos, epistemológicos e filosóficos da Física ao longo de todo o curso. Isso sustenta a hipótese da percepção de conexão entre a profissão e o enfoque histórico-epistemológico presente nas falas dos nossos sujeitos. Essa percepção parece ser adequada já que várias pesquisas sugerem que o debate epistemológico, histórico e filosófico da Ciência nos espaços formativos docentes se configura como uma estratégia profícua para uma melhor preparação dos professores e à superação do ensino dogmático e memorístico que ainda perdura na Educação Científica. Além disso, alguns autores apontam que os conceitos estruturantes da ciência, decisivos para o desenvolvimento científico, podem ser usados como ferramenta capaz de auxiliar na transformação do sistema cognitivo do aluno, levando-os a incorporar novos conhecimentos (GAGLIARDI; GIORDAN,1986). Gagliardi (1988) propõe que a utilização da História da Ciência possibilita aos estudantes uma análise dos momentos de transformação da ciência e de suas teorias, bem como a identificação dos conceitos que promoveram tais transformações. Esse autor considera que a utilização da História da Ciência está no seio de uma transformação do ensino de Ciências, porque pode contribuir para sair de um ensino pautado na transmissão e memorização em direção a um ensino pautado na construção de conhecimentos. Esta é também a defesa de Giordan e De Vecchi (1996). Os autores citados argumentam que o ensino-aprendizagem, que considera a História e a Filosofia da Ciência, favorece a superação do ensino dogmático e fechado e leva à compreensão do empreendimento científico como uma conquista de conhecimentos por aproximações sucessivas através de retificações e múltiplas rupturas. Lombardi (1997) acrescenta que o conhecimento da História e da Filosofia da Ciência pode contribuir para o desenvolvimento do pensamento crítico e para a interpretação de textos e de fatos. Não conseguimos, entretanto, compreender de onde parte ou de onde surge essa valorização dos aspectos histórico-epistemológicos-filosóficos da Física nos entrevistados. Talvez - uma hipótese - venha de expectativas que surgiram antes de ingressarem na Física, quando ainda eram alunos do ensino básico. 


\title{
Física Moderna e Contemporânea
}

Os sujeitos Maxwell, Planck, Gauss deixaram explícito em suas falas que as disciplinas que abordam tópicos de Física Moderna e Contemporânea não foram satisfatórias do ponto de vista do conhecimento gerado. Os depoimentos denotam a sensação dos sujeitos de que não conseguiram aprender:

\begin{abstract}
Eu sinto que não sei nada. Sinto que não sei nada de Física Moderna, porque o curso que fiz aqui foi totalmente canônico, totalmente formal, em termos de não ter sido mais nada além de conta. Se você perguntar pra mim o que é dualidade ondapartícula eu não sei te dizer, só que eu sei escrever a equação do comprimento de onda de De Broglie. Eu sei as Equações do Efeito Fotoelétrico. Eu sei as equações das coisas, mas conceitualmente, na graduação foi totalmente deficiente. (Gauss)
\end{abstract}

A reclamação dos sujeitos parece ter relação com a necessidade de uma discussão conceitual que permita a abordagem da Física Moderna e Contemporânea na escola. Aqui, abre-se um parêntese para comentar que, embora não tenhamos conseguido extrair dados sobre este tema nesta pesquisa, sabemos que já houve manifestações de licenciandos que exigiram que as disciplinas de Física da Licenciatura se aproximassem mais do formalismo trabalhado no bacharelado. De qualquer forma, reclamações como a do Gauss denunciam um fenômeno que ocorre na Licenciatura em Física e que talvez merecesse especial atenção: os conteúdos físicos trabalhados na formação inicial são essencialmente diferentes dos que o professor precisará para ensinar, se ele optar por trabalhar com a Escola Básica. Esse dado é curioso uma vez que temas de Física Moderna são hoje considerados importantes e muito atuais no ensino básico. Entretanto, a formação inicial não está conseguindo munir os professores em formação de elementos que os capacite a tratar dos temas que são relevantes para o ensino básico. Parece que os próprios docentes da graduação talvez não consigam estabelecer quais enfoques parecem ser mais adequados para os licenciandos.

\section{Laboratório de Física}

Se haviam críticas às disciplinas que tratam da Física Moderna e Contemporânea presentes nas falas de alguns entrevistados, as críticas se tornam mais frequentes quando o assunto é Física Experimental ou Laboratório de Física. As críticas aparecem nas falas de cinco sujeitos, desde o formado há mais tempo, até o sujeito formado a menos tempo, e todas são muito semelhantes, isso significa que os sujeitos enxergam os mesmos problemas ou muito próximos nessas disciplinas ao longo de mais de 30 anos. Tipificamos as manifestações em duas categorias de análise: i) o sentido dos laboratórios de física para os sujeitos 
entrevistados; ii) a relação entre os papéis da experimentação na graduação e na escola básica. Buscaremos analisar essas duas categorias com base nas afirmações dos nossos sujeitos.

\section{i) Sentido dos laboratórios de física para os sujeitos entrevistados}

Foi recorrente nas entrevistas afirmações do tipo: "Eu não gostava de Laboratório na Licenciatura" (Herschel), ou "os laboratórios foram ruins" (Feynman), ou "O Laboratório foi asqueroso (...) a parte experimental foi horrorosa, muito ruim” (Fermi), "Eram relatórios imensos que na hora você sabia o que você estava fazendo, mas dois meses depois você não sabia mais nada" (Planck), "Laboratório é um problema. Quando eu fiz foi muito caótico. Primeiro, nós nunca sabemos direito o que estamos fazendo" (Mayer). Essas manifestações negativas sobre os Laboratórios de Física (no geral) estão sempre relacionadas à falta de percepção de propósito, clareza ou sentido das práticas. Por outro lado, nos documentos oficiais (Projeto Pedagógico e Currículo) fica evidente que o objetivo das disciplinas de cunho experimental é o de propiciar aos alunos:

[...] a investigação de diferentes fenômenos físicos através de uma abordagem fenomenológica com o propósito de ser possível que os alunos desenvolvam habilidades fundamentais do trabalho científico, como o levantamento de hipóteses, a construção de procedimentos experimentais e o tratamento de dados quantitativos e a comunicação desses resultados. (PPP, 2015).

Mas é fato que as disciplinas de laboratório no Instituto de Física da USP, e em outros centros de formação, têm relatórios que devem ser preenchidos passo a passo, que pode dificultar o fomento da investigação autônoma dos fenômenos. Fora isso, as disciplinas de laboratório são oferecidas na grade logo após as disciplinas teóricas correspondentes - fato que sugere uma interpretação sobre a função de "aplicação e visualização" de conceitos versus a função de investigação. Parece que foi isso o que aconteceu com os sujeitos Mayer e Maxwell:

Nos são dados experimentos prontos. Nos é dada uma folha com tudo o que devemos fazer: ligar tal botão, posicionar tal coisa em tal lugar, medir tal coisa xis vezes, construir gráfico disso por isso e ajustar o gráfico com base em tal teoria. Mas, mesmo assim, não entendamos nada. (Mayer)

Então eu cheguei ao final do Laboratório 1 e pensei que eu tinha passado o curso inteiro sem nunca ter feito uma reflexão do porquê de estar coletando aqueles dados, como eles poderiam ser analisados. Pegamos a apostila, coletamos os dados, escrevíamos o relatório no padrão, mas sem nenhuma reflexão. (Maxwell)

A fala de Herschel transmite a ideia de que as atividades desenvolvidas nessas disciplinas priorizaram o desenvolvimento de habilidades práticas de manuseio do equipamento e possivelmente a verificação/comprovação de leis e teorias: 
A habilidade que desenvolvi por causa do Laboratório é o de saber operar alguns instrumentos, mesmo que fossem um pouco diferentes daqueles que trabalhamos nas aulas de Laboratório. Eu percebi isso quandoeu fui dar aula de laboratório, eu estava muito insegura porque os equipamentos eram diferentes, mas eu tinha uma noção de operar. (Herschel)

Embora estes aspectos auxiliem na compreensão dos conceitos e transmitam o conhecimento sobre o método científico, práticas desta natureza não são suficientes em processos que visem ao desenvolvimento, no aluno, dos conhecimentos que envolvem o trabalho científico (HODSON, 1994, p. 313). Por abordarem somente aspectos técnicos e práticos, impedem que os estudantes desenvolvam qualquer aspecto representativo quanto à compreensão dos elementos complexos que envolvem a experimentação. Nesse sentido, as falas sugerem que nossos entrevistados tiveram uma percepção de que as atividades dos laboratórios são alicerçadas em concepção empirista-indutivista que compreendem que o conhecimento pode ser obtido através da observação neutra. Se isso se configura nas aulas como nos foi trazido pelos nossos sujeitos, parece então que o caminho memorísticorepetitivo-imitativo se impõe comotransmissor do conhecimento do método científico nas aulas de laboratório dessa instituição. E isso não parece ter um impacto positivo na formação inicial, pelo menos para nossos entrevistados.

As falas dos entrevistados sugerem que seja considerada a hipótese de que o caráter tradicional permeia o ensino, dessa maneira a maioria das práticas experimentais tem como objetivo principal comprovar leis e teorias que visam mostrar aos estudantes a veracidade de tais elementos, levando os alunos a aceitarem determinada teoria como única e verdadeira. Culminam disso meros treinamentos e exercícios de constatações. Colabora com essa hipótese a seguinte fala de Planck:

Nós fazíamos gente fazia os experimentos, calculávamos a equação da onda, geralmente era uma incógnita que você ia atrás e geralmente com essa equação você chegava naquela incógnita, era mais uma parte matemática do que uma parte física de entender o que estava acontecendo ali fisicamente. Acho que foi isso, foi essa impressão que eu acho que eu mais tive dos laboratórios. Eles queriam que você aprendesse a trabalhar com equações e tentar a relacionar aquelas equações com o equipamento, os relatórios eram desnecessários. Eram relatórios imensos que na hora você sabia o que você estava fazendo, mas dois meses depois você não sabia mais nada. (Planck)

Feynman revela através de sua experiência que ele compreende que uma prática experimental deve proporcionar momentos em que os estudantes reflitam sobre o que estão executando e os caminhos que devem ser percorridos para atingir os objetivos da investigação. Quando isso é possibilitado nas disciplinas de laboratório, essa abordagem é valorizada: 
O professor fazia com que os experimentos dessem errado. Tínhamos que entender o que deu errado, era proposital. O normal é o experimento dar errado e você forçar ele dar certo. Mas nessa aula, os experimentos já eram feitos para darem errado. Ali se desenvolvia o senso crítico. (Feynman)

O que essa fala mostra é que esse sujeito valoriza quando a atividade de laboratório preconiza um posicionamento crítico frente às experiências e quando isso acontece através da discussão com o professor e com os colegas, contestando os resultados obtidos e ainda, se possível, encontrando maneiras alternativas de resolver o mesmo problema. Parece que estes momentos são os responsáveis por propiciar aos entrevistados o desenvolvimento da desejada cultura científica, capacitando-o na compreensão do processo científico existente na construção de um conhecimento científico. Então, as falas parecerem contém um pedido implícito de revisão das abordagens instituídas nos Laboratórios de Física.

\section{ii) A relação entre os papéis da experimentação na graduação e na escola básica}

É comum, tanto nas escolas, quanto no ambiente acadêmico, o discurso de que o laboratório e a atividade prática podem ser instrumentos poderosos no processo de ensinoaprendizagem da Ciência e da Física. O pressuposto é o de que por meio da atividade prática ou da experimentação o aluno adquire conhecimento não apenas teórico, mas também de atitudes e conhecimentos próprios da atividade científica. Desta maneira, tanto professores quanto alunos da graduação apontam que o uso de atividades experimentais como estratégia para o ensino de Física tem sido uma das maneiras mais frutíferas de diminuir as dificuldades da aprendizagem dos conceitos da disciplina de Física (ARAÚJO; ABIB, 2003). Embora haja algum consenso sobre a importância da experimentação no ensino, as propostas são discutidas na literatura de maneira bastante diversa quanto ao significado que essas atividades podem assumir em diferentes contextos e em diferentes aspectos. E como as propostas de atividades experimentais no ensino de Física são discutidas no âmbito da formação inicial de professores de Física pelo IFUSP? As falas dos entrevistados parecem sinalizar que, para esses sujeitos, houve alguns espaços fora das aulas de laboratório em que as abordagens experimentais foram discutidas.

Nas aulas de laboratório, o que falas indicam é que os entrevistados percebem a valorização da matematização que focalizam os aspectos quantitativos dos resultados, e com menor peso, do manuseio do equipamento, além do predomínio do caráter demonstrativo ou de verificação em detrimento do caráter investigativo. As falas também demonstraram que os 
sujeitos consideraram as atividades e até as aulas de laboratório como substancialmente negativas. Mas, a despeito de saber como nossos entrevistados utilizam a experimentação em suas aulas, as falas indicam ainda assim que os sujeitos consideram essas atividades importantes. Então, o que isso sugere é que essa ideia não parece ter sido desenvolvida nas aulas de laboratório, mas em outros espaços e momentos da formação, que podem ter sido, por exemplo, através de outras disciplinas.

Herschel revela que desenvolveu a habilidade operacional dos equipamentos experimentais na própria escola onde iniciou a carreira, com auxílio de outro professor da escola:

Eu fui aprender a fazer experimento, a dar aula de Laboratório de Física, quando eu trabalhei com um professor muito bom de Laboratório de Física, em uma escola. Ele era muito bom em Laboratório, então eu fui aprendendo a fazer [experimentos]. (Herschel)

Ela revela ainda que apesar do instrumental ser valorizado nas aulas de laboratório na graduação, ela se sentia insegura, pois os equipamentos das escolas eram diferentes dos da universidade. Já o entrevistado Heisenberg revela que ele desenvolveu habilidades experimentais em duas ocasiões diferentes na Licenciatura: em um projeto em que atuou como monitor de um programa de divulgação científica e na disciplina de Práticas em Ensino de Física. No projeto em que Heisenberg foi monitor, além de auxiliar o público nas atividades da exposição, ele trabalhou com serviços técnicos de montagem dos equipamentos:

Tinha um pátio no salão da pós da mecânica e tinham diversas experiências envolvendo Eletrostática, Termodinâmica etc.[...] Eu aprendi quais eram os princípios físicos envolvidos e aprendi como fazia experiência. Para minha formação inicial foi extremamente importante. Tenho certeza que aprendi muito mais por esse projeto do que se fosse só fazendo os cursos na graduação. Fiquei lá por um ano. Eu fazia a manutenção de alguns experimentos. (Heisenberg)

Na disciplina de Práticas em Ensino de Física,oferecida pela Faculdade de Educação na época de Heisenberg, a professora responsável ajudava com as dúvidas sobre a atividade experimental:

[...] dava aula de física para os últimos anos do fundamental no laboratório da Faculdade de Educação para os funcionários da universidade que não tiveram estudo. Então, para mim foi muito bom, pois esse projeto tinha o acompanhamento de outra professora que estava organizando. Era um paraíso pois eu tinha acesso ao laboratório, às experiências. Eu podia fazer praticamente qualquer experiência que eu quisesse e tinha o acompanhamento da professora. Eu montava uma aula e perguntava para ela se estava bom. Eu tinha todos os instrumentos que precisava e um apoio teórico por trás disso. (Heisenberg)

Então, Heisenberg além de reger suas próprias aulas, tinha uma espécie de mentoria da professora responsável pelo projeto. 
Os entrevistados que vivenciaram a Licenciatura em Física durante a década de 1990 citaram um professor específico do Instituto que levava experimentos de baixo custo para os alunos das disciplinas que ele ministrava. Essas aulas faziam parte do bloco do ensino de física. Segundo os entrevistados, este professor sempre procurava instigar seus alunos a refletirem sobre alguma questão de Física através dos experimentos que levava e procurava relacioná-los com aspectos da sala de aula na escola básica. Os sujeitos que tiveram aula com este professor relembram da disciplina com carinho e, aqueles que não tiveram a oportunidade de ter estas aulas, lamentam um pouco:

\footnotetext{
Fiz uma disciplina em que fazíamos montagens experimentais [...] O professor fazia a gente refletir sobre a questão experimental em sala de aula, com muito material de baixo custo, e eu que estava lecionando em escola pública... Toda aquela preocupação que a gente tinha de fazer o Laboratório do Bacharelado, cheio de equipamentos, eu ficava pensando como eu vou transpor isso para a escola? Então essa disciplina ajudou muito nesse aspecto, descobrimos um mundo. (Maxwell)

Então, o professor dava aula com instrumento simples. Com coisa do dia a dia mas, no ano que eu fui fazer, todo mundo queria fazer com o ele, porque ele bolava umas experiências super legais com coisas super simples. E ele foi para França, daí eu fiz com essa professora que estava entrando, e eu gostei mais ou menos. (Herschel)
}

Já os sujeitos que viveram a Licenciatura a partir dos anos 2000 não fazem referências de terem sido oportunizados em outros espaços ou disciplinas da graduação momentos de desenvolvimento, discussão ou aprendizado sobre a experimentação e o ensino básico. Isso se reflete na fala de Feynman:

Acho que a questão que envolve experimentos voltados para o Ensino Médio é muito frágil na graduação. Por ser um curso voltado para docentes, em especial para o ensino básico, acho que deveria ter uma prática que trabalhasse essa questão. Os laboratórios didáticos que a gente tem são da Física, então a parte de didática, produção de material e experimentos era algo que não deveria ser optativa, deveria ser obrigatória e permear o curso inteiro. Pois é algo que você só constrói ao longo do tempo. (Feynman)

O professor responsável por levar experimentos de baixo custo e discussões sobre a experimentação e o ensino básico se aposentou. Depois dele, no Instituto de Física parece não ter havido outro docente que se dispusesse a trabalhar com essas questões na Licenciatura. Atualmente existe um projeto de divulgação científica, entretanto o professor responsável por esse projeto não ministra aulas do ensino na graduação.

Em contrapartida, parece ter permanecido na disciplina de Práticas em Ensino de Física a tradição entre algumas professoras que a ministram de valorizar as atividades experimentais com materiais de baixo custo. Apesar de a disciplina ter um enfoque mais amplo, ela ainda dá conta de suprir, ao menos em parte, a aparente deficiência da Licenciatura em Física em relação a esse aspecto: 
Na disciplina de Práticas em Ensino de Física [...] fez isso também com uma atividade de refração que ela pegou uma pedra que duplica a imagem e era para a gente refletir sobre aquele fenômeno de Óptica, que era a birrefringência, mas só depois de refletirmos e discutirmos é que a professora explicou. É uma coisa que faz diferença. (Mayer)

Em suma, a hipótese que sustentamos inferida das falas é a de que os entrevistados percebem o papel importante que a experimentação tem como instrumento de ensino. Mas parece ser pouco oportunizado ao longo da graduação espaços para os alunos desenvolverem habilidades em relação a essas atividades. O que inferimos das falas é que existe uma tradição entre algumas professoras do instituto em desenvolver atividades práticas com diferentes enfoques, mas em disciplinas cujo escopo é amplo. Como se pode perceber, quando existe uma oportunidade de trabalhar com a experimentação, os alunos valorizam essa prática e a consideram um elemento significativo da formação.

\subsubsection{Didática da Física: o "brilho nos olhos"}

As disciplinas de Didática da Física são as disciplinas-chave para a formação de professores de Física. Para analisar as falas dos entrevistados acerca desse bloco de disciplinas, tomaremos como ponto de partido um referencial teórico que tenta normatizar quais conhecimentos que se deve esperar que essas disciplinas contemplem na formação. Espera-se que através desse quadro de disciplinas seja desenvolvida sistematicamente uma didática específica da Física que estimule no futuro professor os conhecimentos de natureza epistemológica, de natureza cognitiva e metodológica (NARDI; CASTIBLANCO, 2014). Na dimensão epistemológica insere-se às questões sobre o que ensinar ao aluno da escola básica. Para isso, as disciplinas que focalizam o Ensino de Física devem proporcionar ao licenciando o desenvolvimento de um elemento pouco visível, que é a própria constituição e natureza intrínseca do conhecimento que se pretende ensinar. Para essa finalidade, esse conhecimento tem que ser modificado e alterado para assim permitir a apropriação por outrem. Desta maneira, as disciplinas que focalizam na dimensão epistemológica do ensino da Física devem dar conta de ajudar os licenciandos a compreenderem que os conhecimentos apresentam alguns conceitos que, para uma melhor compreensão pelos alunos do ensino básico, é necessário levar em consideração alguns elementos como: a origem da produção do conhecimento de Física, suas definições formais, a evolução e a natureza dos conceitos de Física, dentre outros. A partir da compreensão desses elementos de ordem endógena, o professor poderá ter uma perspectiva de qual a melhor maneira de ensinar esses 
conhecimentos de forma que o aluno entenda e compreenda a utilidade dos conteúdos aprendidos nas aulas de Física para sua vida cotidiana. Além disso, a apropriação pelo professor da dimensão epistemológica capacita esse profissional a fazer as modificações e alterações da parte do conhecimento que deseja ensinar de maneira adequada e garantir que não sejam perdidos nesse processo o valor científico.

As disciplinas destinadas ao Ensino e à didática da Física também devem conseguir valorizar a dimensão cognitiva. Essa dimensão se refere ao fenômeno multifacetado da aprendizagem, que deve ter como base teorias e vertentes teóricas, que são capazes de produzir descrições e explicações sobre os processos que ocorrem na e para a aprendizagem. A relevância dessa dimensão é a de que o professor consiga estreitar laços entre o que se deseja ensinar e o que é realmente aprendido pelos alunos, servindo, desse modo, como instrumental para a prática do professor. Dessa forma, é necessário que as disciplinas auxiliem o licenciando na compreensão de como os processos de aprendizagemocorrem na estrutura cognitiva do aluno.

A dimensão metodológica deve servir como sustentáculo da superação de modelos de ensino tradicionais transmissivos (em que os alunos têm que permanecer fisicamente estáticos, concentrados, fazendo suas tarefas, nada prazerosas, por longo período de tempo, centrados mais na memorização repetitiva e na assimilação mais ou menos compreensível de conceitos). Através dessa dimensão, o licenciando deve ser convidado a refletir tanto sobre os conhecimentos específicos de Física que vai ensinar, quanto sobre os tratamentos que serão aplicados aos conteúdos específicos no contexto educativo (NARDI; CASTIBLANCO, 2014). Desse modo, espera-se que os futuros professores incorporem repertórios metodológicos e que sejam capazes de movimentar esse reportório adequadamente, de acordo com os objetivos da aula.

Embora as disciplinas do bloco de Didática em Física devessem enfatizem as dimensões acima elencadas, a concepção vigente entre alunos da graduação e em alguns docentes, tanto da Licenciatura quanto do Bacharelado em Física, é a de que se os professores dominarem somente os conteúdos da Física, isso já seria uma garantia de sucesso nas aulas. As dimensões epistemológica, cognitiva e epistemológica viriam na e da prática, sendo, portanto, dispensáveis na formação ou passíveis de serem colocadas em segundo plano. Essa visão dificulta que disciplinas da Didática da Física alcancem seus objetivos, pois, em muitos momentos, não são valorizadas institucionalmente e academicamente. Essa é uma herança das concepções de formação ancoradas no modelo 3+1. O fato é que o professor obviamente precisa ter o domínio do conteúdo como uma condição necessária para o ensino. Mas saber 
bem ou saber muita Física não é suficiente nos processos que focalizam na aprendizagem dos alunos e, por isso, não são garantias de sucesso. O conhecimento específico produzido cientificamente nem sempre é de fácil "digestão intelectual” para os alunos do ensino básico. É essencial, deste modo, que o professor ancore suas práticas em dimensões didáticas e pedagógicas que facilitem o processo de aprendizagem.

Por essa dimensão de importância é que buscaremos analisar o que os nossos entrevistados consideraram como elementos marcantes nas disciplinas que compõem o bloco da Didática em Física, além das suas opiniões e visões. Através das falas dos sujeitos, poderemos identificar as dimensões (epistemológica, cognitiva e metodológica) que foram valorizadas nas aulas. Cabe ressaltar que nos pautamos em uma proposta teórica que tenta criar uma normalização das incumbências da Didática da Física. Esse modelo proposto contem aproximações que tentam traçar um panorama geral sobre o que esperar dessas disciplinas.

O primeiro elemento que chama atenção e que já foi abordado na nossa análise em momentos anteriores (5.2) são as expectativas que os sujeitos deram às disciplinas do Ensino da Física. Os entrevistados sugerem que, através delas e por causa delas, o graduando se sente com os ânimos revigorados para continuar a graduação. Ao analisar as falas, percebemos que esse sentimento relaciona-se a disciplinas que focalizam principalmente a dimensão epistemológica do ensino de Física, que é um dos papéis de várias disciplinas desse bloco, por exemplo, a de Elementos e Estratégias para o Ensino de Ciências:

\begin{abstract}
Quando fiz Elementos e Estratégias para o Ensino de Física foi em um semestre que eu quis trancar o curso pois não estava fazendo sentido [a graduação]. Então, fiz essa disciplina e no começo da disciplina o professor dá textos do Mario Bunge, do Rubem Alves e sabe quando você lembra-se de tudo aquilo que te fez prestar Física no vestibular? Quando o professor apresentou a epistemologia, discutimos trechos de textos que falam sobre como é a Ciência, no caso da "ciência exata", como é o trabalho do cientista, era o tipo de coisa que eu sentia que estava perdendo. E essa disciplina, ao propor o estudo de algumas epistemologias e com as ideias do Thomas Kuhn, que era o propósito, me deu um "gás" novo no curso. (Gauss)
\end{abstract}

A proposta da disciplina em questão é a de proporcionar ao aluno o conhecimento sobre aspectos que compõem o Ensino de Física através do estudo da construção histórica do conhecimento científico, do papel da ciência, da natureza do conhecimento científico, da relação entre o formalismo matemático e a física, a relação entre ciência-cultura-tecnologia, etc. Nas disciplinas da Física, no geral, não são proporcionadas tais discussões. Mesmo porque, tradicionalmente, um Físico (em sua maioria os professores são também pesquisadores) que trabalhe dentro da ciência normal, embora trabalhe fazendo ciência, no geral, não foi treinado para refletir sobre a natureza do conhecimento com o qual trabalha 
(KUHN, 2017). Então, quando surge uma disciplina com um enfoque mais filosófico e epistemológico, os sujeitos apreciam. Apesar da disciplina de Gravitação não fazer parte do bloco da Didática da Física, ela também ilustra bem como as discussões de natureza epistemológica da Física são valorizadas pelos nossos sujeitos (ver seção 5.3.1.3).

O que compreendemos das falas é que discussões das dimensões fenomenológica, histórica, filosófica e epistemológica da Física e do conhecimento científico são ansiadas por muitos alunos da Licenciatura e também do Bacharelado. Parece que a Física, dessa maneira, faz mais sentido em comparação com o sentimento atribuído pelos sujeitos ao modo como são ministradas as disciplinas no curso de Bacharel em Física. Além disso, são disciplinas que promovem conhecimentos que estão contextualizados com o ensino básico e são transversais (ao ensino e à ciência). A hipótese é que, desta forma, além de refletir sobre questões que já devem fazer parte do imaginário dos licenciandos, também refletem aspectos da profissão.

De acordo com as entrevistas, parece colaborar com o sentimento de ânimo revigorado a característica dos professores que são docentes das disciplinas do Ensino contrapondo-se aos das disciplinas da Física. Essa dicotomização fica mais evidente à luz das comparações entre as críticas feitas pelos sujeitos às práticas dos professores nas disciplinas da Física e às práticas (principalmente os que tinham se formado mais recentemente) dos professores do Ensino. Por exemplo, Planck ilustra bem essa oposição nas duas falas abaixo:

\footnotetext{
Nas disciplinas da Licenciatura, quando o aluno tem alguma dúvida, ou quando o aluno tem alguma coisa na cabeça, um questionamento, parece que os professores percebem. Então o professor faz perguntas que provocam no sentido de uma reflexão. E nós passamos a repensar nossos conceitos sobre Física ou algo do ensino. Não sei se é uma característica da "física dura" e da educação - do ensino de física - não sei se é próprio de cada curso, mas eu senti muito essa diferença. (Planck)

Nas disciplinas da Física, parece que a distância entre o aluno e o professor é enorme. Se você tem uma dúvida, parece que problema é do aluno. O aluno tem que se virar [sic] para descobrir, para sanar a dúvida. Ou ainda, os professores passam a impressão de que se o aluno tem dúvida porque não estudou o suficiente. Este é o discurso básico dessas disciplinas. (Planck)
}

Através dessa comparação, pode ser traçado um quadro de oposição entre o que os sujeitos revelaram sobre as disciplinas do Ensino de Física, ministradas por professores pesquisadores da área de Ensino, e as disciplinas da Física, ministradas por professores pesquisadores em Física. Enquanto as disciplinas do conteúdo da Física parecem partir, segundo os entrevistados, da prerrogativa de formação que valoriza o individualismo, a dificuldade, o desempenho ostensivo e o formalismo matemático, no bojo das disciplinas do Ensino de Física, os entrevistados parecem esperar (mesmo que isso não tenha ocorrido) que os professores valorizassem nessas aulas o espírito de colaboração, a compreensão e a 
valorização da dúvida e a análise contextualizada e conceitual dos fenômenos. Sob o prisma dessas oposições, faz muito sentido os alunos da licenciatura não tecerem as mesmas críticas (ou no mesmo teor) aos professores do ensino. E, de certo modo, o teor ${ }^{10}$ das falas sugere implicitamente até certo olhar por parte dos entrevistados de carinho e admiração por esses professores. Não entraremos nas discussões acerca das latentes marginalizações e prestígios de um grupo de professores em detrimento de outro, mas talvez influenciem nas práticas desses grupos de professores e por consequência, o impacto na formação dos alunos.

Além da dimensão epistemológica, outra dimensão aludida nas falas é a metodológica. Essa dimensão é valorizada pelos egressos entrevistados quando elas aparecem, além das disciplinas da Didática da Física, em disciplinas da Física (ver seção 5.3.1). Essa dimensão apareceu quando alguns sujeitos falaram positivamente da extinta disciplina de Tecnologia para o Ensino de Física e da disciplina de Metodologia do Ensino de Física. Entretanto, Práticas em Ensino de Física foi a disciplinas mais comentada (aparece na fala de 5 sujeitos) e por esse motivo, focalizaremos a atenção nela. Dos comentários sobre essa disciplina, pudemos inferir que os sujeitos valorizaram os aprendizados proporcionados por essa disciplina no que diz respeito a como elaborar plano de aula, utilizar experimentos como instrumento de ensino e conduzir uma aula tendo como princípios o construtivismo:

\footnotetext{
Na disciplina de Prática em Ensino de Física, tivemos que fazer uns planos de aula. Tivemos uma aula em que utilizamos baralho para falar de Física de Partícula e a professora aplicou primeiro em nós, isso é bacana. Primeiro a professora faz com a gente, depois nós podemos usar com nossos alunos. E a professora falou depois que você pode aplicar nas suas próprias aulas. Pelo menos pra mim faz diferença, você ver, fazer e depois você aplicar. Para você ter melhor noção. E fez isso também com uma atividade de refração que ela pegou uma pedra que duplica a imagem e era para a gente refletir sobre aquele fenômeno de Óptica, que era a birrefringência, mas só depois de refletirmos e discutirmos é que a professora explicou. É uma coisa que faz diferença. Em relação ao plano de aula, acho que fazer o plano de aula é muito difícil, eu tenho muita dificuldade e quando você vai dar aula você tem um conteúdo inteiro para dar, toda semana você tem que estar na escola, duas vezes por semana, dando aula pra mais de uma turma e você tem que planejar cada uma daquelas aulas, dá trabalho. Se você não tiver tudo pronto num banco de dados, aula de Termodinâmica, aula de Cinemática, etecetera, talvez isso seja complicado. Se você é um professor de primeira viagem, sem um banco de dados seus com planos de aula, você geralmente vai dando aulas iguais a que você teve. (Mayer)
}

Comparando a fala de Mayer com a dos sujeitos que se formaram há mais tempo, Herschel, Heisenberg e Maxwell, pudemos perceber que apesar da disciplina de Práticas em Ensino de Física ter passado a fazer parte das disciplinas oferecidas pelo Instituto de Física

${ }^{10} \mathrm{O}$ "teor" ao qual nos referimos diz respeito à entonação da voz, além da expressão facial e corporal dos sujeitos no momento da fala. São aspectos que, embora subjetivos, também se constituem de fontes de informação. Aqui se justifica a relevância das entrevistas face-a-face. 
(antes era ofertada pela Faculdade de Educação), em termos dos conteúdos e objetivos ela não mudou. E isso parece ter sido positivo, uma vez que a disciplina valoriza aspectos práticos da aula, busca auxiliar o licenciando, a saber, planejar a aula, a organizar e avaliar o aprendizado dos alunos. Tudo isso é proposto através da regência assistida (professoras da disciplina no papel de mentoras), da ênfase ao uso da experimentação (os alunos têm alguns créditos de aula destinados a oficinas dentro do laboratório), e da proposta de promover no licenciando o "hábito" de refletir sobre a prática (os alunos constroem um portfólio de carácter reflexivo). Além disso, essas disciplinas contam com o apoio, muitas vezes, de uma equipe de professores-monitores, alunos do Programa de Pós-Graduação em Ensino de Ciências que participam efetivamente as aulas, acompanham os alunos nas regências e os auxiliam, através de oficinas, a planejar as aulas. A hipótese que se configura para que essa disciplina seja uma das mais valorizadas, podem ser uma consequência do planejamento e da condução das aulas de Práticas em Ensino de Física.

Embora as falas indiquem muitos parâmetros positivos de formação proporcionados pelas disciplinas do bloco de Didática da Física, houve algumas críticas negativas pontuais. Segundo as falas de Gauss e de Feynman, pareceu que eles perceberam vindos de alguns professores das Disciplinas do Ensino, uma falta de conhecimentos práticos, do dia a dia da sala de aula de escola do ensino básico:

\footnotetext{
Por exemplo, nós temos docentes que trabalham a questão de ensino, mas nunca estiveram numa sala de aula. A universidade contrata docentes para o Ensino que nunca trabalharam em sala de aula. Isso para mim é estranho. Então, eu sou um docente que vai formar licenciados para atuarem junto ao Ensino Médio, mas que nunca entrou numa sala de ensino médio, isso é sinistro. Muitas dessas coisas [auxiliar melhor durante o processo de formação inicial] pode ser que aconteça porque muitos professores do ensino não conhecem a escola. Por exemplo, muitos professores se formaram no Bacharelado e perceberam que ensino é uma coisa legal e começaram a ir para o ensino. Mas isso não significa que a grade foi pensada de acordo com o que é necessário para o Ensino. (Feynman)
}

A despeito de alguns professores terem comprovadamente experiência em sala de aula no ensino básico ou não, a crítica é que em alguns momentos da formação nessas disciplinas, os graduandos sentiram que as discussões tomaram consistências teóricas demais ou "muito idealizadas", que culminaram na interpretação de falta de conexão entre teoria e prática sentida por esses entrevistados. Essa mesma sensação parece ter sido experimentada por alguns sujeitos em disciplinas da Formação Pedagógica Geral. Isso pode ser ilustrado através da fala de Gauss:

Práticas em Ensino de Física eu sentia muito que os discursos eram lindos, mas não correspondia a nada da escola onde eu estava fazendo estágio. Eu sinto que o discurso idealizado é tão bonito academicamente, mas chega num ponto que ele não corresponde a nada da realidade escolar e fica simplesmente teórico. Isso me 
incomodou profundamente. Vou dar um exemplo que mais me incomodou [...] Uma das coisas que ela propôs nos estágios de Práticas foi a montagem de uma sequência didática baseada nos Três Momentos Pedagógicos [...] $\mathrm{O}$ momento da problematização acontecia, mas depois surgiam os entraves que a teoria não previa, como esse de ter que improvisar, foi algo que muitos grupos não conseguiram fazer direito. (Gauss)

Além do desapontamento frente ao insucesso da metodologia utilizada na regência, Gauss parece sinalizar a ausência de relação entre a teoria (vista na sala de aula) e a prática (no estágio). Dito de outro modo, o que a fala de Gauss e de Feynman sugere é que era esperado por estes entrevistados que o docente responsável pela disciplina tivesse uma participação mais sistemática de apoio ao aluno e conseguisse direcionar os alunos no sentido de interligar a teoria e a prática. O que se infere das falas é que parece que os sujeitos esperavam que a disciplina proporcionasse a análise e investigação dos aspectos que deram errados da aula, do levantamento de questões e discussões sobre os problemas relacionados aos erros e metodologias, que os licenciandos trariam da experiência concreta. Mas parece que isso não aconteceu da maneira como nossos sujeitos esperavam. Então, a compreensão que os sujeitos construíram sobre essa ausência foi a de que os próprios docentes das disciplinas não têm conhecimento sobre os problemas que acontecem na sala de aula na escola e também não sabem aplicar as metodologias que discutem teoricamente. Críticas surgem também nas falas dos sujeitos sobre a disciplina de Ciência e Cultura:

Ciência e Cultura, era interessante, via a parte cultural da cidade, mas não consigo, como Físico, falar que tem aplicabilidade na sala de aula, eu digo que não. Não via muito sentido, era legal porque a gente passeava, mas em termos práticos de aula não foi útil. Não fez sentido. (Fermi)

A fala de Fermi sugere que ele não conseguiu perceber a conexão entre os objetivos da disciplina e o ensino de Física. O que isso sugere é que não ocorreu o estabelecimento dos vínculos entre a ciência, a educação e a cultura nos entrevistados.

Em contrapartida, os sujeitos consideraram como um elemento importante da formação as disciplinas que abordam outros aspectos da profissão do professor: pesquisas, elaboração de material didático, livro, etc. As disciplinas que abordam essa temática são Propostas e Projetos para o Ensino de Física e Produção de Material Didático. O objetivo da disciplina de Propostas e Projetos para o Ensino de Física é o de analisar projetos nacionais e internacionais de ensino de Física, além das diretrizes e parâmetros que norteiam o ensino no Brasil. À disciplina de Produção de Material cabe o papel de proporcionar aos licenciandos a análise de texto e experimentos, a produção de textos, a produção de material didático, etc. Portanto, essas duas disciplinas abrem portas à outras percepções sobre o trabalho do 
professor que vai além da sala de aula. Ao professor também cabe o papel de produzir e analisar o material que será usado no ensino, rompendo dessa maneira com concepções de professor como mero aplicador de metodologias, didáticas e materiais que foram produzidos por especialistas. Além disso, as duas disciplinas citadas contribuem ao incutir nos futuros professores a dimensão da produção científica que também envolve a educação, tal como Maxwell revela:

Foram as [disciplinas] que me apresentaram para outro mundo que eu não conhecia que é a Pesquisa em Ensino De Física. Se hoje estou na Pós-Graduação, é por causa dessas disciplinas. Eles discutiam e traziam artigos das revistas, tais como o Caderno Catarinense, da Revista Brasileira de Ensino de Física... E nós descobrimos que aquilo [ensino] se pesquisa e tem gente que está produzindo esse tipo de conhecimento! Apesar de ter tido um pouco disso na disciplina [suprimido], a discussão lá era muito teórica. Mas agora começamos a ver que tinha mais que isso, e eles estavam produzindo há mais de 10 anos material sobre Ensino e sobre atividades em sala de aula. Então essas disciplinas me abalaram nesse aspecto. (Maxwell)

Maxwell elucida uma concepção que talvez esteja presente nos licenciandos que é a de que a pesquisa não faça parte da formação do professor e da função do professor. Entretanto, a fala sugere que quando a formação consegue abordar essa dimensão profissional, isso pode dar condições de ajudar a incutir nesse futuro professor processos que os ajudem a assumir a sua própria realidade escolar como um objeto de pesquisa, de reflexão e de análise. De acordo com Nóvoa (2001), isso constitui-se em um movimento contra hegemônico, frente ao processo de desprofissionalização do professor e de instrumentalização da sua prática (NÓVOA, 2001). Nesse sentido, Maxwell indica que quando foram apresentados a ele esse universo de atuação, começou a se desenvolver nele uma (re) configuração do conceito do ser professor que tiveram frutos o fato de hoje, ele ser também pesquisador, além de professor.

As disciplinas de Metodologia do Ensino de Física 1 e 2, apesar de serem ofertadas pela Faculdade de Educação, devido a dimensão do conhecimento que elas abordam, se enquadram na dimensão descritiva Didática da Física.

\subsubsection{Disciplinas da Formação Pedagógica Geral}

Quando falamos de disciplinas identificadas como de "Formação Pedagógica Geral" nos referimos às disciplinas que são oferecidas, geralmente, pela Faculdade de Educação (no caso da USP). São disciplinas que abordam um conjunto de conhecimentos comuns a todo e qualquer professor, independente da área de ensino, e tratam de aspectos relativos às ciências da educação (SHULMAN, 1986). Os conhecimentos tratados nessas disciplinas, explicita 
Gauthier et al (1998), ainda que não ajudem diretamente o professor a ensinar, são indispensáveis, na medida em que desenvolvem no futuro professor conhecimentos a respeito das facetas da sua profisssão ou da educação de um modo geral. São exemplos desses conhecimentos as noções sobre o sistema escolar, sua administração e gestão, as políticas educacionais, os fundamentos sociais, históricos e filosóficos da educação, a evolução da própria profissão, a aprendizagem e o desenvolvimento humano (entre outros).

Mas, historicamente, a formação pedagógica em cursos de licenciatura é secundarizada em relação ao conhecimento disciplinar do conteúdo a ser ensinado, tanto do ponto de vista legal, quanto da organização e desenvolvimento dos currículos, de suas disciplinas e atividades. Mesmo diante do consenso acadêmico-científico acerca da importância e da imprescindibilidade das componentes pedagógicas e disciplinares para a formação adequada de um professor, as disciplinas de formação pedagógica recebem tratamentos desarticulados e desconexos das propostas de formação.

A secundarização e tratamentos desarticulados e desconexos das propostas parecem ser herança do modelo de formação 3+1. A formação pedagógica, mediante esta organização, além de desarticulada da formação disciplinar e do sistema educacional em que o professor irá atuar, acaba colaborando com a visão de que a Licenciatura é um mero apêndice das diferentes formas dos bacharelados atuarem. A ideia que se transmitia é a de que a Licenciatura - e, por consequência, suas disciplinas - são apenas "requisito burocrático para o exercício do magistério" (SCHEIBE, 1983, p.32).

Colaboram com essa desarticulação e falta de conexão entre a formação pedagógica geral e a formação específica o fato dessas disciplinas serem função de duas unidades distintas. Isso pode dar margem à criação de duas estruturas institucionais distintas de formação do professor - a da faculdade de educação, ou de filosofia, de um lado, e os institutos que tratam do conteúdo a ensinar, de outro. Essas estruturas institucionais distintas configuram-se como desdobramentos do modelo 3+1. Desta maneira, acentua-se a desvinculação entre o conteúdo específico e o conteúdo pedagógico da formação do professor.

Ocorre que Institutos de Ensino Básico são os responsáveis pelos estudos dos conteúdos específicos a serem objetos da docência e a Faculdade de Educação é responsável pelos assuntos de cunho pedagógico, necessários à formação do professor. No caso da Licenciatura em Física pelo Instituto de Física da USP, existe documentado (HAMBURGUER, 1981) que desde 1980, os alunos se queixam da dicotomização da formação. Tais queixas aludem que, a despeito da Licenciatura em Física ser de responsabilidade de dois institutos (O Instituto de Física e a Faculdade de Educação), não 
ocorria diálogo e coordenação entre eles. Sendo assim, pelos motivos apresentados até aqui, procuramos ouvir dos nossos entrevistados quais marcas as disciplinas da Faculdade de Educação deixaram na formação desses sujeitos.

O primeiro aspecto nas falas dos sujeitos sobre as disciplinas da Formação Pedagógica Geral que chama atenção é o desprezo que foi relatado existir entre os alunos da Licenciatura pelas disciplinas desse bloco: "eu percebia em alguns colegas, na disciplina da Educação certo desprezo por elas, mesmo em colegas da Licenciatura." (Maxwell), "No geral, o pessoal desprezava as disciplinas da educação, mas eu gostava bastante.” (Heisenberg), "eu acho que existe certo preconceito em quem faz Licenciatura em relação às disciplinas de educação. Isso eu ouço de colegas, eles falam que não serve pra nada" (Herschel). Esses relatos indicam que nossos sujeitos parecem enxergar o predomínio de um consenso entre os alunos da Licenciatura. Esse consenso reflete uma ideia de secundarização das disciplinas de formação pedagógica geral frente às disciplinas de formação disciplinar. Mayer parece corroborar com esses relatos ao apontar a sua própria concepção sobre as duas áreas do conhecimento:

Daí você acaba vendo que o pessoal dessa área [do ensino] não é bobo. Eu pensava isso, no ensino médio talvez eu visse as coisas como desse jeito que a gente vê, uma coisa como hierarquicamente melhor que a outra [dicotomização entre Bacharelado e Licenciatura]. Ser pesquisador de Física Pura, você trabalhar com Física Teórica, Experimental, enfim, é muito melhor do que você pensar em como Ensinar Física. E parece que não passava pela minha cabeça que você tem que pensar na Física e em pensar em como saber ensinar. Antes, era como se fosse uma coisa pronta, que aprendemos e aplicamos. E não é bem assim. (Mayer)

Mayer indica que, embora houvesse nela uma concepção hierarquizada, essa concepção mudou. Comparando as falas, parece que nossos entrevistados percebem uma visão dicotomizada partindo de alunos da Licenciatura sobre as disciplinas da Formação Pedagógica Geral e as de Física. Alguns entrevistados sugerem que eles mesmos tinham essa visão. Mas, analisando o percurso formativo dos nossos entrevistados, parece ter acontecido algo diferente na trajetória dos nossos sujeitos que pôde, porventura, ter provocado mudanças nas suas concepções sobre as disciplinas em questão, indo a um sentido oposto da concepção dos outros alunos. Mayer e, possivelmente Planck, Fermi, Maxwell, Heisenberg e Herschel encaram as disciplinas de Formação Pedagógica Geral sob enfoques diferentes em relação aos outros alunos da Licenciatura em Física. Nesse sentido, é interessante a fala de Maxwell:

Quando vim para a Licenciatura eu já queria ser professor [...]. E, para mim, o que era discutido nas disciplinas [de Formação Pedagógica] era muito importante, eu discutia isso com eles, eu falava que não dava para ter essa postura: você pode não gostar de um texto ou não gostar de um professor, mas a discussão sobre didática, por exemplo, é fundamental [...] As pessoas achavam que para ser professor não precisava daquilo que era discutido nas disciplinas da Faculdade de Educação. Eu pensava que esse isso é porque aquele aluno da graduação não tinha ido para a sala de aula. Por isso eu falo que essa experiência que eu tive de seis meses de hardcore 
na escola, com um grupo preocupado com a educação, com uma equipe que me adicionava e que se preocupavam comigo [...]. Eu fui incorporando naquele semestre as coisas que eu estava discutindo com os colegas e isso fez a diferença na minha formação. Mas eu não via isso nos colegas na licenciatura. (Maxwell)

O que a fala sugere é que como Maxwell vivenciou a experiência concreta em sala de aula, pode decorrer disso que as discussões teóricas da Formação Pedagógica, para esse sujeito, tinham sentidos diferentes que para seus colegas. A leitura que se pode fazer daí tem o mesmo teor das discussões travadas em "O momento de crise: a escolha pela licenciatura": uma hipótese é que os saberes das disciplinas teóricas da Formação Pedagógica parecem fazer mais sentido para o aluno quando a estes são oportunizados momentos de, ele próprio, formular as perguntas ou o problema. Dito de outro modo, parece que a experiência concreta da sala de aula oportuniza momentos de observação e reflexão que, por sua vez, proporcionam indagações. Essas indagações têm como ponto de partida os problemas emergentes da prática cotidiana dos professores, do contexto da escola e dos processos de ensino e aprendizado, relativamente aos quais quer se dar respostas. Isso sugere que, num primeiro momento, os entrevistados até tinham concepções que refletem ideias hierarquizadas entre as disciplinas da Formação Pedagógica e as de Física, mas a importância e o sentido daquelas disciplinas na profissão de professor ganham corpo quando esses sujeitos conseguem relacionar as teorias discutidas com a experiência concreta. A fala de Gauss sobre a disciplina de Política e Organização da Educação Básica no Brasil - POEB parece ir ao sentido da hipótese proposta:

POEB é uma disciplina útil. Concordo. Mas mal dada. E eu acho que ela está no momento errado, quando eu tive no segundo semestre, era muito imaturo para entender tudo aquilo que era dado e eu acho que ela é mais útil no fim do curso. Por que você estuda a legislação, você estuda teorias de currículo? Acho que tem que ser mais para os últimos semestres, porque muita gente acha que por ela ser uma disciplina muito informativa, as pessoas se afastam pelo menos as pessoas da Física, não sei de outras licenciaturas. Eu me senti muito afastado, e depois que eu me formei, foi incrível, um dia eu sentei e fui ler a LDB, por iniciativa própria. (Gauss)

Um aspecto curioso da fala de Gauss é a sua percepção de imaturidade frente às discussões propostas na disciplina. No sentido da nossa hipótese, parece que o sentimento relatado por Gauss tem origem na ideia de que os problemas que eram discutidos na disciplina não faziam sentido para ele naquele momento da formação. Tais problemas foram fazer mais sentido quando o sujeito se encontrava em estágios mais avançados do curso, o que pressupõe mais conhecimento sobre o ensino, os processos de ensino, da escola, etc. e por consequência, mais perguntas a serem respondidas.

A fala de Mayer ajuda a corroborar a hipótese, pois essa entrevistada viveu a grade da Licenciatura de 2015. Uma novidade nessa grade em relação às disciplinas da Formação 
Pedagógica são as horas de estágio que estão diluídas entre as disciplinas obrigatórias oferecidas pela Faculdade de Educação. POEB é uma dessas disciplinas que, além das horas teóricas, exige 20 horas de observação em escola:

[...] acho que quando escolhemos ser professor funciona assim, eu serei contratada por uma escola, vou dar aula e acabou. Pois o que eu tenho com a escola é um contrato e um compromisso de dar aulas. Mas em POEB, por exemplo, você acaba conhecendo todas as esferas políticas e administrativas do que acontece dentro da escola. Como funciona toda organização, como a escola é planejada, o que tem por trás do financiamento da escola, como o projeto político é planejado, como isso interfere nos aspectos do dia a dia, como a escola enxerga o conselho participativo... todas essas coisas que na disciplina ficou mais claro. Outra coisa que eu aprendi em POEB é sobre a escola democrática, sempre ouvia falar, mas não sabia seu funcionamento. Então, depois da disciplina, eu tive maior noção de como funciona de fato e o que significa uma escola democrática. No próprio estágio de POEB pude fazer em uma escola de ensino fundamental e este estágio me possibilitou perceber a visão dos professores, da direção, dos alunos, conhecer o diretor e a coordenadora, a presença deles e sua relação com todos, professores, alunos e funcionários. Que nessa escola a relação é diferente de onde faço estágio da disciplina de Práticas, então consigo comparar as duas escolas, pois elas funcionam de maneiras diferentes. (Mayer)

Então, desde seu primeiro momento como aluna da Licenciatura, Mayer esteve inserida no contexto da escola. Desta maneira, a fala de Mayer sugere que por ela ter experienciado a escola, parece que isso ajudou com que as discussões travadas na disciplina fossem melhores assimiladas e fizessem mais sentido, diferentemente de Gauss.

A disciplina POEB foi a mais citada entre os entrevistados, cinco sujeitos falaram sobre ela. Isso significa que foi uma disciplina que marcou substancialmente nossos sujeitos. O fato de ela estar alocada no primeiro ano da graduação pode ser que contribua como marco na formação:

POEB e Metodologia do Ensino de Física. Essas duas me marcaram bastante porque elas traziam abordagens bem diferentes sobre o ensino. Como eu tinha uma visão de ensino muito tradicional, elas já conseguiram desconstruir muita coisa dessa visão [...] Os professores nessas disciplinas levantavam questões dentro da aula, que exigia reflexão. E ficamos nos questionando e isso motivava a buscar mais conhecimento [...] (Planck)

Entretanto, analisando os sentidos dados pelos sujeitos às marcas deixadas pela disciplina POEB, ocorre muita variação de sentido (vide Quadro 14). Entretanto, é curiosa a fala de Fermi, que foi um dos sujeitos que ao iniciar a Licenciatura, já lecionava em escola do ensino básico:

Na Faculdade de Educação tinham umas matérias gerais que não são nenhuma da Física, lá você faz um monte de matéria, umas seis ou sete, de vários cursos tais como POEB, Psicologia da Educação, mas você não sente respaldo, você tem que fazer porque tem que fazer, mas não dão respaldo para a sala de aula. Eram teóricas demais, você lia alguns autores e discutia o que eles pensam, mas não sei se esses autores eram do estrangeiro e tinham alunos ideais, educados, formados. Mas não condiz com a realidade do Brasil [...] (Fermi) 
Apesar de ele ter vivido a experiência concreta da sala de aula, parece que Fermi vê a problemática proposta nas disciplinas da Formação Pedagógica Geral como muito distanciadas do seu dia a dia como professor. Isso sugere uma hipótese. Parece que este sujeito reivindica implicitamente mais diálogo entre a teoria vista nas disciplinas e os problemas reais que ele enfrenta na sala de aula. Era esperado que a experiência do Fermi em escola talvez pudesse colaborar com a atenuação da dicotomização entre teoria e prática, mas, de acordo com sua fala, acabou por reafirmar essa dicotomização. 


\section{Conclusão}

Através desta pesquisa, buscamos compreender como é o processo formativo proporcionado pelo Instituto de Física da USP no curso de Licenciatura em Física sob o ponto de vista de egressos. Buscamos também comparar as percepções dos entrevistados sobre a Licenciatura com as ambições constantes nos Projetos Políticos Pedagógicos e, dessa forma, procuramos compreender alguns parâmetros positivos de formação que essa instituição promove ou promoveu, de acordo com a percepção dos entrevistados.

Para atingir esse objetivo foram feitas análises documental dos Projetos Políticos Pedagógicos e demais documentos que pudessem revelar informações importantes sobre essa Licenciatura e os processos de reestruturações curriculares pelas quais passou. Estes processos de reestruturações do currículo foram analisados à luz das Legislações brasileiras que norteiam a formação e o ensino. Também foram analisados dados que revelam o número de concluintes de cursos de Licenciatura em Física no país e da Instituição lócus desta investigação. Além disso, ouvimos de alguns profissionais egressos do curso suas opiniões, visões e elementos marcantes sobre o processo formativo vivenciado. Dos temas que os entrevistados abordaram mais enfaticamente nas entrevistas, foram construídas as dimensões descritivas. Essas dimensões revelaram os aspectos da formação que foram mais relevantes profissionalmente (positiva ou negativamente) e isso nos auxiliou na compreensão do processo de formação vivenciado pelos sujeitos.

Sobre o dado do número de concluintes do curso da Licenciatura em Física oferecido pelo IFUSP, é interessante a análise do Gráfico 1 - Evolução do número de concluintes da Licenciatura em Física (1997 a 2016). Neste gráfico é notório o aumento da taxa de formados durante os primeiros 10 anos após a implementação da nova licenciatura. Esse dado é muito importante pois revela o esforço do IFUSP em levar adiante as propostas de reformulação do currículo do curso. O bem-sucedido aumento do número de concluintes da Licenciatura em Física durante a primeira década sugere três pontos promissores em termos de formação: o primeiro é que, o fato de se ter desvinculado o currículo da Licenciatura do currículo do Bacharelado, contribuiu com a formação de uma identidade curricular de formação de professores de Física Essa é a principal sugestão preconizada por McDermott (1990) para diminuir alguns problemas presentes em cursos de formação de professores. Essa proposta de desvinculação dos currículos visou diminuir ou acabar com os efeitos do modelo $3+1$, o que demonstra que já era conhecido entre os membros docentes do Instituto que os efeitos de um 
curso padrão para ambas as formações não era adequado à formação de professores de Física. A partir dessa ruptura de currículos fica evidente quais são os objetivos e intenções da formação. O segundo ponto é que ao focalizamos nosso olhar para as enormes reformulações estruturais que a Licenciatura em Física pela USP sofreu, é possível constatar que houve uma intenção muito clara da comunidade acadêmica em torno de uma concepção de formação. Isso garantiu que o Projeto Político Pedagógico de 1993 não se tornasse apenas uma carta de intenções. O que se configura é que houve um esforço muito grande por parte dos docentes do Instituto para garantir que o projeto fosse efetivamente colocado em prática. Esse esforço dos docentes pode ser medido através do empenho na reformulação e construção dos planos das disciplinas para adequá-las às necessidades formativas do professor de Física. Isso significa a valorização do corpo docente frente à profissão que se deseja formar. O terceiro ponto diz respeito ao fato de a reformulação da Licenciatura em Física pela USP ter precedido a Legislação, o que demonstra que não somente havia no Instituto um corpo docente comprometido com a formação, mas que foi capaz de diagnosticar uma realidade e propor soluções. Isso possibilita avaliar que a Legislação, ao corroborar práticas que já estavam em andamento no IFUSP, não foi adotada impositivamente, de cima para baixo, mas, ao invés disso, colaborou para legitimar ideias e práticas que já se configuravam como relevantes pelos atores diretamente envolvidos com o fenômeno. Esses pontos colocados em relevância através da análise do Gráfico 1, por si só já permitiriam propor alguns parâmetros bem sucedidos de formação de professores e explicar o que fez com que os alunos da Licenciatura permanecessem no curso e conseguissem concluí-lo.

Em relação às entrevistas, um tema recorrente na fala dos egressos relaciona-se com os motivos que levaram os informantes a escolherem a Licenciatura. A dimensão descritiva $O$ Momento de crise: a escolha pela Licenciatura mostra que boa parte de nossos entrevistados vieram para a Licenciatura em Física evadidos do Bacharelado. Com base no modelo de Tinto (1984), uma hipótese possível é a de que a experiência institucional vivenciada por esses egressos no curso de Bacharelado em Física (ou correlato) não tenha sido capaz de promover a integração social e acadêmica destes alunos. As entrevistas mostraram que esses egressos não possivelmente não desistiram totalmente do curso de Física porque tiveram a opção de mudar de curso através da transferência para a Licenciatura em Física. A licenciatura seria, nesse caso, uma última chance que o aluno dá para Física antes de evadir totalmente do curso. Nesse processo, os alunos vão para a Licenciatura, tristes por dois motivos: porque não era a primeira opção enquanto carreira profissional e por causa da decepção na sua experiência com a Física. Porém, ao chegar na Licenciatura os alunos são surpreendidos positivamente e 
renovam sua motivação para concluir o curso. A Licenciatura estaria, portanto, sendo capaz de acolher os alunos que desejavam ser físicos, mas que ficaram descontentes com o curso de Bacharelado em Física. Esse dado em colabora com parte da explicação sobre o maior número de formados na Licenciatura em Física pelo IFUSP - afinal, apesar de nossos dados não terem relevância estatística, sugerem que pode estar havendo duas formas majoritárias de ingresso: via vestibular e via transferência entre cursos.

Embora existam críticas dos alunos da Licenciatura em Física em relação às disciplinas de Física, é curioso que tais críticas, embora contundentes, não culminaram na evasão desses entrevistados. A permanência desses alunos no curso sugere a hipótese (já mencionada anteriormente) de que algo dentro desta formação inicial consegue gerar disposição (ou parâmetros positivos de formação) nos alunos para que eles se mantenham no curso com o objetivo de se formarem professores. Contudo, as entrevistas revelaram que não são as disciplinas da Física as responsáveis por essa disposição. O que nossos sujeitos revelaram como o fator mais preponderante de contentamento com o curso são as discussões situadas que aconteciam em determinadas disciplinas, que nós englobamos dentro do conjunto chamado de Didática da Física. Essas disciplinas são aquelas ministradas pelo Instituto de Física e Faculdade de Educação (no caso da disciplina de Metodologia de Ensino de Física) e que são interdisciplinares entre o conteúdo de Física e o conteúdo histórico, ou pedagógico, ou filosófico. E foram essas instâncias que, de acordo com os profissionais entrevistados, os "encantaram" enquanto alunos. Assim, seria esse um parâmetro positivo de formação, de acordo com a percepção dos profissionais entrevistados e um fator que colabora com a permanência dos alunos na Licenciatura em Física.

Além disso, acreditamos que as disposições que garantem a permanência dos alunos na Licenciatura também são geradas, em grande medida, como consequência das disciplinas que cunham questões epistemológicas, históricas e filosóficas do conhecimento Físico junto a uma discussão conceitual da Física. Tais disciplinas são, principalmente, Gravitação e Elementos e Estratégias para o Ensino de Física. Referenciais em formação de professores nos autorizam a inferir que tal fenômeno acontece porque essas disciplinas são ministradas por professores mais diretamente ligados ao estudo da profissão docente, do aprendizado e do ensino da física, e que, portanto, são mais preparados para tratar dos temas com ênfase no que o profissional em formação reconhece como relevante, em termos de conhecimento específico para atuar. Essas disciplinas dão conta ainda de contribuir com a compreensão fenomenológica da física e de familiarizar os licenciandos com os processos de construção do conhecimento. Os alunos veem sentido na formação e se sentem, por consequência, 
motivados a continuar com a graduação - o já referido "brilho nos olhos". Assim, as discussões propostas por essas disciplinas e suas abordagens estão dentro do contexto de atuação profissional dos licenciandos. Esse fato também se constitui de outro parâmetro positivo de formação e que colabora com o sucesso relativo da Licenciatura em Física pelo IFUSP.

Entretanto, um fato curioso é os entrevistados terem mencionado as abordagens Epistemológica e Histórica da Física como sendo importantes dimensões do conhecimento para o trabalho pedagógico desses profissionais, e não terem citado outras abordagens ou dimensões. Por exemplo, a abordagem cognitivista ou abordagem experimental não foram apontadas pelos profissionais entrevistados como conhecimentos importantes para a atuação do professor na escola básica. Uma hipótese para a omissão de algumas dimensões ou abordagens nas falas dos entrevistados pode estar relacionada com a característica das linhas de pesquisa desenvolvidas pela equipe docente do Ensino do Instituto de Física hoje. A equipe que compõe o quadro docente no IFUSP atualmente trabalha com as dimensões Epistemológicas e Históricas do Ensino de Física e Ciência. Talvez por essa razão não enfatizem as outras abordagens em suas aulas para a Licenciatura. Referenciais que tratam sobre o currículo oculto (SACRISTÁN, 2000) podem dar conta de explicar esse fenômeno.

O dado acima parece colaborar com a ideia de que o papel do formador seja fundamental na constituição de parâmetros positivos de formação, na percepção dos sujeitos. O papel do docente consiste também de um fator preponderante em relação a permanência dos entrevistados no curso. Para os entrevistados, a prática dos professores no conjunto de disciplinas da Didática da Física é positiva. O referencial de Schön (2000) permite interpretar que os entrevistados valorizaram a prática dos professores nessas disciplinas, pois, estes preconizaram ou preconizam abordagens heurísticas e propostas que envolvem reflexão relacionada à prática. Essa pode ser uma consequência do fato de que os docentes que costumam atuar no bloco da Didática da Física fazem parte do Programa de Pós-Graduação Interunidades em Ensino de Ciências. Isso contribui para que esses professores estejam constantemente em uma espécie de formação continuada, que tem como reflexo suas práticas em sala de aula.

Se, de um lado é observado o quanto as disciplinas do bloco da Didática da Física são importantes para o currículo e pela permanência dos alunos no curso, um fato muito alarmante é que os entrevistados não percebem as outras disciplinas dessa forma. Ao olhar para os dados referentes à dimensão descritiva As disciplinas: visões, opiniões e elementos marcantes, nossa população amostral nas entrevistas não foi capaz de corroborar todas as intenções elencadas 
no Projeto Político Pedagógico. Apesar de todas as propostas dos projetos da graduação em questão serem modernas e bem embasadas em referenciais teóricos adequados para a formação profissional, aparentemente, as reclamações dos nossos sujeitos de pesquisa, principalmente em relação às disciplinas do conteúdo da Física, não parecem diferir muito das reclamações dos alunos de outros institutos do país.

Tais críticas aconteceram principalmente em relação às práticas que ocorrem nas disciplinas, tais como: avaliações que não condizem com as aulas, promoção do autodidatismo e valorização da dificuldade em detrimento da ajuda do professor para superação da mesma. Algumas considerações também se estendem à ementa das disciplinas, tais como: valorização da análise matemática formal que não é compatível com o ensino básico e falta de elo entre o que os alunos aprendem na graduação e o que vão ensinar na escola. Os entrevistados apontam, adicionalmente, que a ênfase no formalismo e na operacionalização matemática ocorre em detrimento de discussões aprofundadas do ponto de vista conceitual. Consistindo essa em uma avaliação negativa dos egressos sobre o curso e em um dos conhecimentos que os egressos sentiram falta em relação às suas necessidades profissionais

No entanto, quando os licenciandos reclamam de muito formalismo, há de se ter um cuidado de não compreender que os anseios seriam da abolição da operacionalização matemática na formação. Implicitamente, está contido nas reclamações que os alunos sentem falta de uma base conceitual mais sólida. Somente o enfoque formal e operacional, sem a discussão do formalismo e do conceito, não está sendo suficiente para dar a fundamentação necessária ao licenciando para que ele consiga transpor a Física para o aluno da escola básica, algo que deve acontecer com o rigor e a precisão característica da ciência, mas sem o formalismo matemático que é visto na graduação. Esse é um conhecimento que os egressos sentiram falta em sua atuação profissional. A análise dessa situação poderá ser feita de maneira mais pormenorizada em trabalhos posteriores utilizando-se o referencial teórico proposto por Chevallard.

É mister reconhecer ainda que, embora haja reclamações sobre as disciplinas da Física (conteúdo a ensinar), algumas práticas docentes foram valorizadas e consideradas positivas na formação pelos entrevistados (consistindo de uma avaliação positiva sobre a formação de acordo com os egressos). Isso demonstra que alguns docentes dessas disciplinas tentam levar aspectos da profissão de professor para as aulas e é fato que os alunos apreciam quando essas tentativas acontecem. Quando as tentativas são bem sucedidas, positivas, os alunos acabam incorporando tais práticas e interiorizando-as como suas - processo chamado por Schön 
(2010) de imitação. Isso acontece principalmente quando os licenciandos percebem empenho por parte dos docentes, personalização do ensino, adequações dos planos de aula ao longo da disciplina e dos anos, transversalidade das discussões e postura questionadora perante a compreensão dos alunos sobre os conceitos. Essas tentativas docentes são valorizadas e apreciadas pelos egressos, porém elas não são comuns e não parecem revelar uma apropriação adequada das propostas e das concepções de formação contidas nos projetos pedagógicos da Licenciatura. De acordo com a percepção dos egressos, parece que alguns dos docentes da Licenciatura não compreendem o que significa levar para as aulas aspectos do Ensino de Física na educação básica ou da profissão de professor de Física do ensino básico para as aulas da graduação.

Quanto aos Laboratórios de Física, os Projetos PolíticoPedagógicos nas versões de 2006 e 2015 não fazem menção a essas disciplinas. Tal fato preocupa, pois, se não estão postos no projeto do curso os objetivos formativos dessas disciplinas, cada professor fica autorizado a conferir uma leitura pessoal sobre esse objetivo. A literatura preconiza que essas disciplinas devessem contribuir com o aprendizado dos conceitos e dos métodos científicos, visando o conhecimento dos experimentos desenvolvidos na Física. Mas, diante das reclamações dos entrevistados, as experiências e o trabalho prático tradicionalmente desenvolvido nas aulas de Laboratório de Física não têm sido adequados para aproximar os alunos de conceitos importantes, dificultando mais que estimulando o desenvolvimento de conhecimentos científicos, outra avaliação sobre o curso e um dos conhecimentos que os egressos mais sentiram falta na sua formação e atuação. Embora essas disciplinas estejam entre espaços e tempos mais adequados para promover aos futuros professores discussões aprofundadas sobre o papel da atividade experimental no fazer científico e sobre os próprios conceitos e modelos da Física, parece não haver competência por parte da instituição formadora em reconceitualizar o papel que as atividades desenvolvidas nos laboratórios desempenham para a formação de professores. As queixas mostram que este conhecimento é lacunar na formação, pois as atividades desenvolvidas não motivam os alunos, são distanciadas das necessidades profissionais, as técnicas adquiridas não se relacionam positivamente com o ponto de vista educacional, o trabalho no laboratório não contribui para ajudar os alunos a compreender melhor os conceitos científicos, a imagem que os alunos adquirem sobre a ciência e a atividade científica não se ajustam a prática científica real. Os laboratórios parecem estar sendo, nesse sentido, mais do que inúteis, contraproducente na formação desses profissionais. 
Todavia, algumas das deficiências das aulas de laboratório foram supridas durante algum tempo por docentes que se dispunham a oferecer disciplinas da Didática da Física cujas propostas envolviam a experimentação e a sala de aula do ensino básico (tal como a disciplina de Produção de Material Didático que foi mencionada por entrevistados que se formaram antes do ano 2000), mas com as aposentadorias que começaram a ocorrer no Instituto a partir de 2000, essa prática não foi assumida por outros docentes, tornando-se uma parte lacunar na formação.

Com esse dado, voltamos novamente nossa atenção para o Gráfico 1 - Evolução do número de concluintes da Licenciatura em Física (1997 a 2016). Após a reforma da Licenciatura de 1993, que culminou no bem sucedido aumento do número de concluintes desse curso durante alguns anos, o número de concluintes permaneceu mais ou menos estável durante a década seguinte. Porém, percebemos que a taxa de concluintes vem caindo ano a ano desde 2010. Coincidentemente, durante os anos 2000, a Licenciatura em Física viu muitos dos seus docentes se aposentarem. Isso significou a redução do quadro de docentes ligados ao Ensino de Física de 17 para 7 (2018). Como a maior parte dos docentes do Instituto que atuavam no Ensino foram contratados na década de 70, por volta dos anos 2000, esses docentes completaram mais de 30 anos de carreira. Por esse motivo, se aposentaram. Porém, esse contingente não foi suprido em sua totalidade com novas contratações de professores voltados para o Ensino de Física e, a maioria dos novos docentes contratados, parece não ter se envolvido com essa questão. Então, talvez a queda do número de concluintes possa ser um reflexo do número menor de professores que estão próximos ou envolvidos mais diretamente com as questões do Ensino de Física. Se houvesse no Instituto 17 docentes do Ensino de Física como há 20 anos, isso significaria que boa parte desses professores eventualmente ministraria aulas de Física (conteúdo a ensinar), ou de Laboratórios de Física, além das próprias disciplinas da Didática da Física. Os dados de concluintes e as falas dos entrevistados apontam na direção da hipótese de que o número atual de docentes no Instituto parece não ser insuficientes para dar conta da formação de professores de Física. Outra hipótese é que ocorre uma carência de formação específica para os docentes que ministram aulas para a Licenciatura.

Quanto às disciplinas da Formação Pedagógica Geral, os dados deixam evidente que há pouco interesse dos alunos por elas e que os entrevistados pouco compreendem a relevância das propostas das aulas e os objetivos dessas disciplinas. Um dado interessante que merece investigação é que os egressos que relataram apreciação positiva de tais disciplinas foram aqueles que tiveram a oportunidade de vivenciar a prática profissional antes ou 
concomitantemente às disciplinas. Essa pode ser vista como uma evidência da dicotomização entre teoria e prática. Percebemos que houve um movimento da grade curricular de $2006 \mathrm{em}$ alocar disciplinas pedagógicas a partir do primeiro ano de curso, o que parece não ter sido uma boa estratégia em termos de formação. As entrevistas demonstram que as disciplinas pedagógicas gerais são concebidas segundo a lógica disciplinar - altamente fragmentadas, especializadas como unidades autônomas, fechadas em si mesmas e de curta duração (TARDIF, 2002), faltando interlocução entre os diferentes locus de formação-. Desse modo, elas acabam revitalizando a dicotomização e, portanto, a ideia de que "na prática, a teoria é outra". Os dados das entrevistas permitem construir algumas hipóteses. A primeira sugere que a maneira como essas disciplinas estão organizadas hoje, nos faz imaginar que elas pertenceriam mais adequadamente à formação continuada. A segunda hipótese que os dados sugerem, é que essas disciplinas possam carecer de horas de trabalho ou estágio associadas, de modo que, permanecendo numa grade de paradigma disciplinar, pudessem diminuir a dicotomização teoria-prática. E uma última hipótese que podemos traçar é a de que esse bloco de disciplinas devesse voltar a ser alocado no final do curso. Dessa maneira, a comunidade poderia escolher outras disciplinas, talvez dentre as mais específicas da formação de professor de Física, para os anos iniciais do curso.

Talvez a segunda hipótese tenha sido percebida pela comunidade docente, o que pode ter tido reflexo na proposta da grade de 2015, que alocou horas de estágio em todas as disciplinas da Formação Pedagógica. De fato, essa mudança pode ser promissora no sentido de minimizar esse problema ao colocar o estágio como parte do processo, e não como fim do processo da formação inicial. Infelizmente não foi possível verificar se essa modificação foi fortuita para o fenômeno, pois nossa investigação teve apenas um representante do currículo novo.

Mesmo não tendo sido o enfoque desta investigação voltar a atenção para o início da carreira profissional dos egressos, essa temática apareceu espontaneamente nas entrevistas. Por esse motivo, buscamos analisar essas informações e o que os egressos revelam na dimensão descritiva Início da atuação como professor de Física. Tal como as pesquisas indicam acontecer nas Licenciaturas em Física em geral, os egressos da Licenciatura em Física da USP também passam por momentos de tensão e conflitos no início da carreira, muito similares a de egressos de outras instituições. Entretanto, quando o início da carreira dos egressos entrevistados aconteceu em ambientes favoráveis à aprendizagem, de trocas entre os pares, que ofereceram poucos riscos de desgaste ou de sobrecarga de trabalho e, quando os egressos perceberam acompanhamento vindos de "mentor" ou coach que oriente a 
prática (que pode ser a coordenação pedagógica da escola, outros professores experientes ou ainda, orientadores da Pós-Graduação), a transição entre a formação inicial e o início da carreira aparenta ser mais suave. Alguns dos nossos entrevistados receberam esse suporte. Todavia, isso não partiu de ações institucionais. Com isso é possível compreender que a instituição não se compromete com a inserção profissional de seus egressos e com o início da carreira: salvo quando os egressos ingressam no Programa de Pós-Graduação em Ensino de Ciências.

Contudo, o fato de termos muitos entrevistados evadidos do Bacharelado extremamente descontentes, desanimados e quase desistindo do curso de Física que ingressaram Licenciatura por esses motivos e que, apesar de estarem na Licenciatura, ainda apresentam queixas quanto as disciplinas de Física, esses mesmos entrevistados mantiveramse dispostos a dar andamento no curso e obter o diploma (diferentemente de quando estavam no Bacharelado, cujo pensamento recorrente era desistir dessa graduação). Esse dado sugere a seguinte hipótese: apesar de esses entrevistados terem criticado muito as disciplinas de Física, ocorreu alguma diferença significativa no modo como as disciplinas de Física (conteúdo a ensinar) são planejadas e conduzidas pelos docentes entre o Bacharelado e a Licenciatura. Isso sugere que os docentes que ministram disciplinas de Física para a Licenciatura têm um cuidado maior ao planejar as aulas para esses alunos. Os egressos revelam, a partir das suas críticas que, apesar de não ser ideal, pelo menos não contribuem negativamente na formação. Esse dado fica interessante à luz de uma fala da entrevistada Meyer em que ela afirma que os alunos da Licenciatura parecem ser mais críticos em relação às práticas dos docentes nas disciplinas. Isso sugere a hipótese de que os alunos da licenciatura observam as ações docentes mais atentamente e por isso, também acabam sendo mais exigentes em relação às aulas.

Assim, tendo em vista o objetivo desta pesquisa, que era o de compreender como o Instituto de Física da USP vem se posicionando diante das propostas dos Projetos PolíticosPedagógicos, analisamos os documentos que norteiam a Licenciatura. A análise documental dos projetos político pedagógico evidenciou que as propostas contidas nos documentos são pioneiras em termos de formação de professores e de concepções de ensino. Além disso, a análise forneceu indícios de que a formação oferecida pelo Instituto está alinhada com modelos e concepções contemporâneas de formação. Os indícios são: a formação de uma identidade curricular própria para a Licenciatura em Física através da criação de um currículo independente do curso de bacharelado em Física; a garantia da oferta de disciplinas dentro da estrutura de blocos, em um regime que torna a formação inicial mais flexível; a proposta de 
um currículo mais dinâmico, de acordo com os objetivos atuais de formação; a oferta de disciplinas que discutam aspectos epistemológicos da Física; a presença de um programa de Pós-Graduação que permite, dentre outras coisas, a formação continuada dos próprios professores do Instituto de Física; criação de uma comissão permanente de avaliação e acompanhamento da licenciatura; tornar obrigatória a PCC em disciplinas do Instituto e incorporar na grade a disciplina de Ciência e Cultura; trazer para o Instituto a responsabilidade de uma parcela das horas de estágio; preconizar a discussão de aspectos profissionais dentro das disciplinas. Todas essas propostas tiveram reflexo, pelo menos, na alta taxa de concluintes por ano em relação à média nacional.

Era esperado ser possível verificar tais indícios através das entrevistas. Porém, diante das informações trazidas pelos egressos, parece que nem sempre ocorre uma compreensão clara e uma apropriação adequada das propostas do Projeto Político Pedagógico da Licenciatura em Física oferecida pelo IFUSP pelos docentes.

A partir dessas informações, é possível propor que seria profícuo que a comunidade docente do Instituto avaliasse a possibilidade de fazer algum tipo de formação continuada com os professores que trabalham na Licenciatura hoje, de modo a garantir a continuidade da tradição pioneira de formação de professores iniciada em 1990. Nossas entrevistas permitem sugerir que essa formação continuada devesse promover discussões que ajudassem os docentes a:

- Como fazer a formalização matemática nas aulas de Física e ao mesmo tempo fazer uma discussão conceitual compatível com as demandas do ensino básico;

- Como as disciplinas de Física podem constituir um elo entre o que se ensina na graduação e o que se ensina no ensino médio;

- Como a didática das aulas na Licenciatura nas disciplinas de Física poderiam inspirar as práticas dos futuros professores na escola básica;

- Como os laboratórios podem ser ressignificados tendo em vista dos objetivos conceituais, atitudinais e epistemológicos de acordo com as necessidades dos licenciandos;

- Como diminuir as distâncias entre as disciplinas de Formação Pedagógica Geral e as disciplinas da Física e da Didática da Física;

- Como promover a interlocução entre os diferentes institutos responsáveis pela formação; 
- Como a Licenciatura poderia ajudar o egresso na sua inserção profissional.

Aparte essas recomendações, o Instituto de Física da USP consegue proporcionar aos licenciandos uma formação bastante promissora frente a outros centros do País. Isso pode ser verificado pela constatação do número de concluintes. Além disso, muitos professores formados pelo Instituto são profissionais muito bem colocados no meio educacional. Portanto, da compreensão de como a Licenciatura em Física pela USP ocorre na prática e do posicionamento desta licenciatura diante dos documentos norteadores da formação, dos dados dos números de concluintes do curso e das percepções dos egressos sobre essa Licenciatura, reveladas através de entrevistas, pudemos atingir o objetivo mais geral da pesquisa. Inferimos desses dados que o Instituto de Física consegue promover os seguintes parâmetros positivos de formação:

- O primeiro e principal deles foi ter criado um currículo da Licenciatura desvinculado ao da formação do Bacharel, que garante uma identidade curricular específica de formação de professores;

- Oferecer ao licenciando disciplinas com enfoques em dimensões epistemológicas (fenomenológica, histórica e filosófica) da Ciência e da Física como acontece na disciplina de Gravitação e em Elementos e Estratégias para o Ensino de Física;

- Também são parâmetros positivos de formação as disciplinas que proporcionem conhecimentos que estão contextualizados com o ensino básico e que são transversais (ao ensino e à ciência);

- Oferecer disciplinas que focalizam a dimensão metodológica: como elaborar plano de aula, utilizar experimentos como instrumento de ensino e conduzir uma aula tendo como princípios o construtivismo;

- Disciplinas que valorizem os aspectos práticos da aula, que busquem auxiliar o licenciando na maneira como planejar e organizar a aula, que deem ênfase ao uso da experimentação e que promovam reflexão sobre a prática.

Todos estes são elementos preconizados pelos Projetos Políticos-Pedagógicos da Licenciatura desde 1993. O papel do docente mostrou-se ser também fundamental na constituição de parâmetros positivos de formação, de acordo com os entrevistados. Isso quando na sua atuação, o docente valoriza o espírito de colaboração e de compreensão; valoriza a dúvida dos alunos; promove análise contextualizada e conceitual dos fenômenos físicos; demonstra empenho no planejamento e execução da aula; é heurística; usa a 
experimentação e reflexão como elementos primordiais do processo; usa elementos da prática profissional para privilegiar a integração de competências; oportuniza o diálogo entre formador e formando; ajude o aluno a "clarificar o pensamento" através de questionamento e aconselhamento. 


\section{REFERÊNCIAS $^{11}$}

ADMIRAL, T. D. Dificuldades conceituais e matemáticas apresentadas por alunos de física dos períodos finais.Revista Brasileira de Ensino Física [online]. 2016, v. 38, n.2, apr 19, 2016. ISSN 1806-1117. doi: http://dx.doi.org/10.1590/S1806-11173822122. Acessado em 23/04/2019.

ALARCÃO, I. Professores reflexivos em uma escola reflexiva. v. 104, São Paulo: Cortez, 2003. (Coleção questões da nossa época).

ALVES FILHO, J de P. Atividades experimentais: do método à prática construtivista. 2000. 312 f. Tese (doutorado) - Universidade Federal de Santa Catarina, Florianópolis, 2000.

ALVES, J. A. P. A formação inicial de professores de física e a construção de uma identidade. 2010. 233 f. Tese (doutorado) - Universidade Estadual Paulista, Bauru, 2010.

ANDERSON, O. R. A neurocognitive perspective on current learning theory and science instructional strategies.Science Education, v. 81, n. 1, p. 67-89, 1997.

ARAÚJO, M. S. T; ABIB, M. L. V. S. Atividades experimentais no ensino de física: diferentes enfoques, diferentes finalidades. Revista Brasileira de Ensino de Física, v. 25, n. $2,2003$.

ARAUJO, R. S.; VIANNA, D. M. A história da legislação dos cursos de Licenciatura em Física no Brasil: do colonial presencial ao digital a distância.Revista Brasileira de Ensino de Física, São Paulo, São Paulo, v. 32, n. 4, p. 1-12, 2010.

BARDIN, L. Análise de conteúdo. Lisboa: Edições 70, 2007.

BEJARANO, N. R. R.; CARVALHO, A. M. P. de. A história de Eli. Um professor de Física no início de carreira. Revista Brasileira de Ensino de Física, v. 26, n. 2, p. 165 -178, 2004.

BOGDAN, R. C.; BIKLEN, S. K. Investigação qualitativa em educação. Tradução Maria João Alvarez, Sara Bahia dos Santos e Telmo Mourinho Baptista. Porto: Porto Editora, 1994.

BRASIL, Ensino Médio. Parâmetros curriculares nacionais: língua portuguesa. Brasília: MEC/SEF, 1997.

BRASIL. CONSELHO NACIONAL DE EDUCAÇÃO (CNE). CONSELHO PLENO (CP). Resolução CNE/CP n ${ }^{\circ}$, de 18 de fevereiro de 2002. Institui Diretrizes Curriculares Nacionais para a Formação de Professores da Educação Básica, em nível superior, curso de licenciatura, de graduação plena. Diário Oficial da União, 2002.

BRASIL. Lei de Diretrizes e Bases da Educação Nacional. LDBEN. Lei, 1996.

BRASIL. Parâmetros Curriculares Nacionais. Ciências da Natureza e Matemática e suas Tecnologias. Secretaria de Educação Fundamental, Brasília: MEC, 2000

BRASIL. Parâmetros Curriculares Nacionais: Ciências Naturais. Brasília: MEC, 1998.

\footnotetext{
${ }^{11}$ De acordo com a Associação Brasileira de Normas Técnicas (ABNT NBR 6023).
} 
CACHAPUZ, A. et al. A necessária renovação do ensino das ciências. São Paulo: Cortez, 2005.

CARR, W.; \& KEMMIS, S. Becoming Critical: Education. Knowledge and Action Research. London: Falmer: 1986.

CARVALHO, A. M. P. O ensino de Ciências e a proposição de sequências didáticas investigativas. In: (Org.) Ensino de Ciências por investigação: condições para implementação em sala de aula. cap.1, p.1-20, São Paulo: Cengage Learning, 2013.

CARVALHO, A. M. P.; \& GIL-PÉREZ, D. Formação de professores de ciências: tendências e inovações. v. 26, 4º ed. São Paulo: Cortez, 2000 (Coleção questões da nossa época).

CARVALHO, J.S.F. Construtivismo: uma pedagogia esquecida da escola. Porto Alegre: Artes Médicas, 2001.

CONTRERAS, J. A autonomia de professores. São Paulo: Cortez Editora, 2002. 296 p.

FERNÁNDEZ, I.; GIL-PÉREZ, D.; CARRASCOSA, J.; CACHAPUZ, A.; PRAIA, J.

Visiones deformadas de la ciencia transmitidas por la enseñanza. Enseñanza de las Ciencias, n. 20, p.477-488, 2002.

FRANCO, M. L. P. B. Análise de Conteúdo. 3 ed. Brasília: Liber livro editora, 2008.

GAGLIARDI, R. Cómo Utilizar la Historia de las Ciencias en la Enseñanza de las Ciencias.

Enseñanza de las Ciencias, 6 (3), p. 291-296, 1988.

GAGLIARDI, R.; GIORDAN, A. La História de las Ciencias: Una Herramienta para la Enseñanza. Enseñanza de las Ciencias, v.4 (3), p. 253-258, 1986.

GASPAR, A. Cinqüenta anos de ensino de física: muitos equívocos, alguns acertos e a necessidade do resgate do papel do professor. In: XV Encontro de Físicos do Norte e Nordeste, 1995, Natal. Anais ... Natal: 1995.

GATTI, B. A. Formação de professores no Brasil: características e problemas. Educação \& Sociedade, Campinas, v. 31, n. 113, p. 1355-137931, dez - out, 2010. Disponível em: <http://www.redalyc.org/articulo.oa?id=87315816016>Acesso em: 22 mar. 2019.

GAUTHIER, C. et al. Por uma teoria da pedagogia: pesquisas contemporâneas sobre o saber docente. Ijuí: Unijuí, v. 2, p. 131-151, 1998.

GIL-PÉREZ, D. et al. ¿Puede hablarse de consenso Constructivista en la educación Científica? Enseñanza de las Ciencias, v.17, n.3, p.503-12, 1999.

GIORDAN, A.; DE VECCHI. As Origens do Saber. Porto Alegre: Artes Médicas, 1996.

GLASERSFELD, E. V. Cognition, Construction of Knowledge, and Teaching. Synthese, v. 80 (1), p.121-140, 1989.

GUERRA, L. B. O diálogo entre a neurociência e a educação: da euforia aos desafios e possibilidades. Revista Interlocução, v. 4, n. 4, p. 3-12, jun. 2011. 
GUIMARÃES, Y. A. F. Identidade Curricular da formação inicial de professores de física. 2014. 342 f. Tese (doutorado) - Faculdade de Educação, Instituto de Física, Instituto de Química e Instituto de Biociências, Universidade de São Paulo, São Paulo, 2014.

HAMBURGUER, A. I. Licenciatura em Física na USP em perspectiva. In: Colóquio do Instituto de Física, Instituto de Fìsica da USP, São Paulo, 1981. Colóquio... 1981.

HODSON, D. Hacia um Enfoque más Crítico del Trabajo de Laboratório. Enseñanza de las Ciências, Barcelona, v. 12, n.3, p. 299-313, 1994.

HORKHEIMER, M. Eclipse da razão. São Paulo: Centauro, 2002

INSTITUTO DE FÍSICA DA UNIVERSIDADE DE SÃO PAULO. Projeto Político Pedagógico da Licenciatura em Física de 1993. IFUSP, 1992.

INSTITUTO DE FÍSICA DA UNIVERSIDADE DE SÃO PAULO. Projeto Político Pedagógico da Licenciatura em Física de 2006. IFUSP, 2005.

INSTITUTO DE FÍSICA DA UNIVERSIDADE DE SÃO PAULO. Projeto Político Pedagógico da Licenciatura em Física de 2015. IFUSP, 2015.

KUHN, T. A estrutura das revoluções científicas. $13^{\circ}$ ed. São Paulo: Perspectiva, 2017

LIMA JÚNIOR, P. Evasão do ensino superior de Física segundo a tradição

disposicionalista em sociologia da educação. 2013. 258 f. Tese (doutorado) - Programa de Pós-Graduação em Ensino de Física, Instituto de Física, Universidade Federal do Rio Grande do Sul, Rio Grande do Sul, 2013.

LOMBARDI, O. I.. La Pertinencia de la Historia en la Enseñanza de Ciencias: argumentos y contraargumentos. Enseñanza de las ciencias: revista de investigación y experiencias didácticas, v. 15, n. 3, p. 343-349, 1997.

MASETTO, M. T. Competência pedagógica do professor universitário. São Paulo: Sumus Editorial, 2003.

MASSABNI, V. G. O construtivismo na prática de professores de ciências: realidade ou utopia. Ciências \& Cognição, v. 10, 2011.

MAYRING, Ph. Einführung in die qualitative Sozialforschung [Introdução à pesquisa social qualitativa]. $5^{\text {a }}$ ed. Weinheim: Beltz, 2002.

MCDERMOTT, L. C. A perspective on teacher preparation in physics and other sciences: The need for special science courses for teachers. American Journal of physics, v. 58, n. 8, p. 734-742, 1990. doi https://doi.org/10.1119/1.16395.

MINAYO, M. C. S. Pesquisa Social. Teoria, método e criatividade. 18 ed. Petrópolis: Vozes, 2001.

MOREIRA, M. A. Ensino de física no Brasil: retrospectiva e perspectivas. Revista Brasileira de Ensino de Física, São Paulo, v. 22, n. 1, p. 94-99, 2000.

NARDI, R.; CASTIBLANCO, O. L. Didática da física. São Paulo: Cultura Acadêmica, 2014. 
NOVAK, J. D. Construtivismo Humano: um consenso emergente. Ensino das ciências: diário de pesquisa e experiências didáticas. v. 6, n. 3, p. 213-223, 1988.

NÓVOA, A. O professor pesquisador e reflexivo. [Entrevista concedida a]Salto para o Futuro. TVEscola. 13 set 2001. Disponível em <https://api.tvescola.org.br/tve/saltoacervo/interview;jsessionid=360D0C55FBA58EB74BF2B4539E1932FA?idInterview=8283> . Acessado em: 14 fev 2019.

OSBORNE, J.F. Beyond constructivism. Science Education, v.80 (1), p. 53-82, 1996.

PENA, F. L. A. Sobre a presença do Projeto Harvard no sistema educacional brasileiro. Revista Brasileira de Ensino de Física, São Paulo, v. 34, n. 1, p. 1-4, 2012.

PERRENOUD, P. A. Prática Reflexiva no ofício de professor: profissionalização e razão pedagógica. Porto Alegre: Editora Artmed, 2002.

POLATI, F.; DIAS, V. S.; ZANETIC, J. A disciplina Gravitação no Curso de Licenciatura em Física da USP: objetivos e fundamentos de uma proposta guiada pela história e filosofia da ciência.[online] Khronos, n. 4, p. 72-83, 2017. doi:

https://doi.org/10.11606/khronos.v0i4.134222 Acessado em: 05/01/2019.

PUGLIESE R. M. O trabalho do professor de Física no ensino médio: um retrato da realidade, da vontade e da necessidade nos âmbitos socioeconômico e metodológico.[online] Revista Ciência e Educação. v. 23, n. 4, p. 963-978, dez, 2017. doi: http://dx.doi.org/10.1590/1516731320170040006. Acessado em: 23/04/2019.

ROTH, W. M. Learning process studies: examples from physics. International Journal of Science Education, v. 20(9), p. 1019-1024, 1998.

SACRISTÁN, J. G. O currículo: uma reflexão sobre a prática. 3. ed. Porto. Alegre: Artmed, 2000.

SANTOS, M. E. V. M. Que Educação? Tomo I. Lisboa: Santos EDU, 2005.

SCHEIBE, L. A formação pedagógica do professor licenciado: contexto histórico.

Perspectiva, Florianópolis, v.01, n.01, p.31-45, 1983.

SCHÖN, D. A. Educando o profissional reflexivo: um novo design para o ensino e a aprendizagem. São Paulo: Artmed, 2000.

SHULMAN, L. S. Those who understand: knowledge growth in teaching. Educational researcher, v. 15, n. 2, p. 4-14, 1986.

SILVINO, A. M. D. Epistemologia positivista: qual a sua influência hoje?. Psicologia: ciência e profissão, v. 27, n. 2, p. 276-289, 2007.

TARDIF, M. Saberes docentes e formação profissional. $17^{\circ}$ ed. Petrópolis: Editora Vozes, 2002.

TINTO, V. Leaving college: rethinking the causes and cures of student attrition. 2. ed. Chicago: The University of Chicago Press, 1987.

ZABALA, A. Os enfoques didáticos. In: O Construtivismo na sala de aula. $6^{\mathrm{a}}$ ed. São Paulo: Editora Ática, 2003. 
ZEICHNER, K. M. O professor como um profissional reflexivo. Cadernos de pedagogia, v. 220, p. 44-49, 1993. 